A Manual for Applying the Allowable Residual Contamination Level Method for Decommissioning Facilities on the Hanford Site
B. A. Napier
W. E. Kennedy, Jr.
G. F. Piepel
R. G. Schreckhise

August 1988

Prepared for the U.S. Department of Energy under Contract DE-AC06-76RLO 1830

Pacific Northwest Laboratory

Operated for the U.S. Department of Energy

by Battelle Memorial Institute 


\title{
DISCLAIMER
}

This report was prepared as an account of work sponsored by an agency of the United States Government. Neither the United States Government nor any agency thereof, nor Battelle Memorial Institute, nor any or their employees, makes any warranty, expressed or implied, or assumes any legal liability or responsibility for the accuracy, completeness, or usefulness of any informat ion, apparatus, product, or process disclosed, or represents that its use would not infringe privately owned rights. Reference herein to any specific commercial product, process, or service by trade name, trademark, manufacturer, or otherwise does not necessarily constitute or imply its endorsement, recommendation, or favoring by the United States Government or any agency thereof, or Battefle Memorial institute. The views and opinions of authors expressed herein do not necessarily state or reflect those of the United States Government or any agency thereof, or Battelle Memorial Instifute.

\author{
PACIFIC NORTHWEST LABORATORY \\ operated by \\ BATTELLE MEMORIAL INSTITL'TE \\ for the \\ UNITED STATES DEPARTMENT OF ENERGY \\ under Contract DE-AC06-76RLO 1830
}

\begin{tabular}{|c|c|}
\hline \multirow{2}{*}{\multicolumn{2}{|c|}{ Printed in the United States of America }} \\
\hline & \\
\hline \multicolumn{2}{|c|}{$\begin{array}{c}\text { Available from } \\
\text { National Technical Information Service }\end{array}$} \\
\hline \multirow{3}{*}{\multicolumn{2}{|c|}{$\begin{array}{c}\text { National Technical Information Servire } \\
\text { United Stattss Department of Commerce } \\
5285 \text { Port Royal Road } \\
\text { 5pringfield, Virginia } 22161\end{array}$}} \\
\hline & \\
\hline & \\
\hline \multirow{2}{*}{\multicolumn{2}{|c|}{$\begin{array}{l}\text { NTIS Price Codes } \\
\text { Microfiche A01 }\end{array}$}} \\
\hline & \\
\hline \multicolumn{2}{|c|}{ Printed Copy } \\
\hline & Price \\
\hline Pages & Codes \\
\hline $001-025$ & $\mathrm{~A} 02$ \\
\hline $026-050$ & A03 \\
\hline $051-075$ & $\mathrm{~A} 04$ \\
\hline $076-100$ & $\mathrm{~A} 05$ \\
\hline $101-125$ & A06 \\
\hline $126-150$ & $\mathrm{~A} 07$ \\
\hline $151-175$ & $A 0 B$ \\
\hline $176-200$ & $\mathrm{~A} 09$ \\
\hline $201-225$ & A010 \\
\hline $226-250$ & $A 071$ \\
\hline $251-275$ & A012 \\
\hline $276-300$ & $\mathrm{~A} 013$ \\
\hline
\end{tabular}


PNL -6348

UC -602

\section{A MANUAL FOR APPLYING THE ALLOWABLE RESIDUAL CONTAMINATION LEVEL METHOD FOR DECOMMISSIONING FACILITIES ON THE HANFORD SITE}

B. A. Napier

G. F. Piepel

W. E. Kennedy, Jr.

R. G. Schreckhise

August 1988

Prepared for the

U.S. Department of Energy under Contract DE-ACO6-76RLO 1830

Pacific Northwest Laboratory Richland, Washington 99336 
$\vdots$
$\vdots$
$\vdots$
$\therefore$ 


\section{SUMMARY}

The Allowable Residual Contamination Level (ARCL) method, as presented by Kennedy and Napier $(1983 a, b)$ was developed to assist the U.S. Department of Energy's (DOE) Richland Operations Office decominission the retired nuclear production reactors and associated facilities situated on the Hanford Site, which is located in south-central Washington state. The method is intended to help evaluate decommissioning alternatives by using a site-specific radiation scenario/exposure-pathway analys is to determine the acceptable levels of residual radioactive contaminants that can remain in a nuclear facility that is to be decommissioned in situ. The maximum allowable residual levels of radioactive material is based on an annual dose limit to potentially exposed individuals.

This report describes the modifications that have been made to enhance the original ARCL method to make it more applicable to site-specific analyses. This version considers the mixture of radionuclides present at the time of site characterization, the elapsed time after decommissioning when exposure to people could occur, and includes a calculation of the upper confidence limit of the potential dose based on sampling statistics that are developed during the site characterization efforts. The upper confidence limit of potential exposure can now be used for comparison against applicable radiation dose limits (i.e., $25 \mathrm{mrem} / \mathrm{yr}$ at Hanford). The level of confidence can be selected by the user. A wide range of exposure scenarios were evaluated; the rationale used to select the most limiting scenarios is explained.

The radiation dose factors used for the inhalation and ingestion pathways were also updated to correspond with the radiation dosimetry methods utilized in the International Commission of Radiological Protection Publications 26 and 30 (ICRP 1977; 1979a,b, 1980, 1981, 1982a,b). This simplifies the calculations, since "effective whole body" doses are now calculated, and also brings the dosimetry methods used in the ARCL method in conformance with the rationale used by $O O E$ in developing the $25 \mathrm{mrem} / \mathrm{yr}$ iimit at Hanford.

Step-by-step procedures are included in this report for the convenience of the user. Example calculations are also included in the Appendix. 


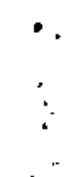

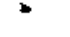

:

$*$ 


\section{ACKNOWLEDGMENTS}

The authors would like to thank all of the individuals that have helped in the development, review and finalization of the Allowable Residual Contamination Level method over the past five plus years. We would especially like to thank all the people in Hanford's decommissioning programs (i.e., Westinghouse Hanford Company, UNC Nuclear Industries, who was in charge of decommissioning operations in the 100 Areas prior to the consolidation of operations at Hanford in 1987, and the U.S. Department of Energy's Richland Operations office) for their support and patience during the development and testing of this method. These individuals include John Adams, John Beckstrom, Bryan Carlson, Jack Collins, Tom Dabrowski, Ken Gano, Jim Goodenough, John Hall, Clarence Miller, Bob Potter, Dwayne Speer and Dick Winship. We would also like to express special appreciation to Joe Soldat and the late Ed Watson for their guidance during the development of the philosophy used in this method. Our thanks also to the typists Toni Jewell, Carolyn Schauls, Susan Cammann, and the editor Jim Weber. 


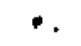

. 


\section{CONTENTS}

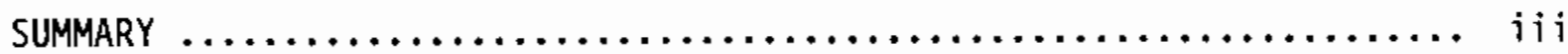

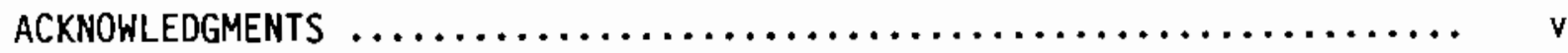

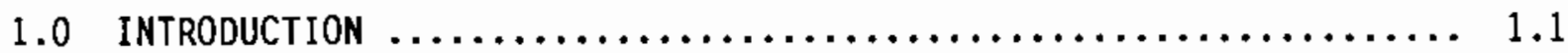

1.1 EXISTING DECOMMISSIONING STANDARDS $\ldots \ldots \ldots \ldots \ldots \ldots \ldots \ldots, 1.3$

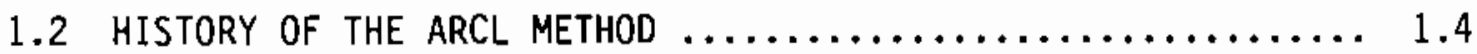

1.3 OVERVIEW OF THE MODIFICATIONS TO THE METHOD $\ldots \ldots \ldots \ldots \ldots, 1.5$

2.0 Allowable Residual CONTAMination LeVEl MethOD $\ldots \ldots \ldots \ldots \ldots \ldots 2.1$

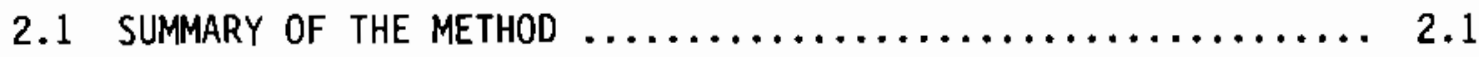

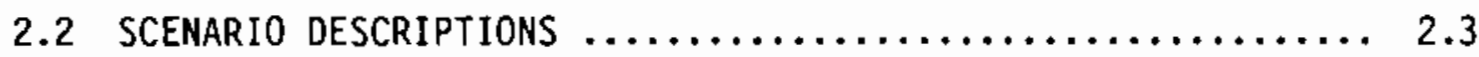

2.2.1 Resource Recycle Scenario $\ldots \ldots \ldots \ldots \ldots \ldots \ldots \ldots . . . \ldots \ldots$

2.2.2 Residential/Home-Garden Scenario .............. 2.4

2.2.3 Agricultural Scenario $\ldots \ldots \ldots \ldots \ldots \ldots \ldots \ldots \ldots \ldots \ldots \ldots$

2.3 DOSE FACTORS FOR RADIATION EXPOSURE PATHWAYS $\ldots \ldots \ldots \ldots \ldots 2.8$

2.4 SCENARIO-SPECIFIC DOSE CONVERSION FACTORS $\ldots \ldots \ldots \ldots \ldots \ldots 2.10$

3.0 EXPOSURE SCENARIOS CONSIDERED BUT DISMISSED $\ldots \ldots \ldots \ldots \ldots \ldots \ldots, 3.1$

3.1 ADDITIONAL INTRUDER SCENARIO PATHWAY DESCRIPTIONS $\ldots \ldots \ldots \ldots .3 .1$

3.1.1 Biotic Transport Scenario .................... 3.3

3.1 .2 Groundwater Migration Scenario $\ldots \ldots \ldots \ldots \ldots \ldots \ldots . . .4$

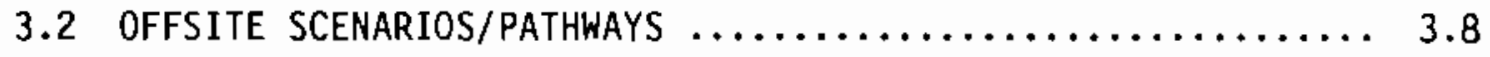

3.3 ADDITIONAL SCENARIO DOSE CONVERSION FACTORS $\ldots \ldots \ldots \ldots \ldots . . . . . .3$

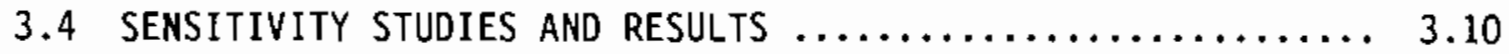

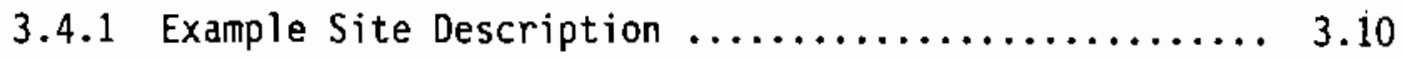

3.4 .2 Scenario Result Comparison $\ldots \ldots \ldots \ldots \ldots \ldots \ldots \ldots . .10$

3.4.3 Discussion of Results $\ldots \ldots \ldots \ldots \ldots \ldots \ldots \ldots \ldots \ldots \ldots \ldots \ldots \ldots$ 
4.0 A STATISTICAL APPROACH FOR MAKING REMEDIAL ACTION DECISIONS BASED

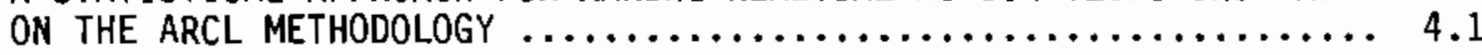

4.1 STATISTICAL REMEDIAL ACTION DECISIONS FOR THE HANFORD

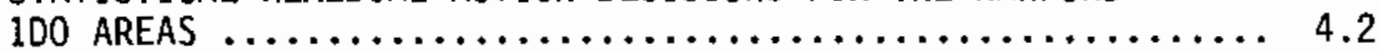

4.2 THE $100(1-\alpha) \%$ UPPER CONFIDENCE LIMIT DECISION RULE $\ldots \ldots \ldots 4.2$

4.2.1 Main Formulas for UCL $\ldots \ldots \ldots \ldots \ldots \ldots \ldots \ldots \ldots \ldots \ldots \ldots \ldots \ldots \ldots$

4.2 .2 Discussion $\ldots \ldots \ldots \ldots \ldots \ldots \ldots \ldots \ldots \ldots \ldots \ldots, 4.4$

4.3 COMPUTATION OF SCENARIO DOSE AND STANDARD OEVIATION ESTIMATES FOR STRATIFIED RANDOM SAMPLING $\ldots \ldots \ldots \ldots \ldots \ldots, 4.5$

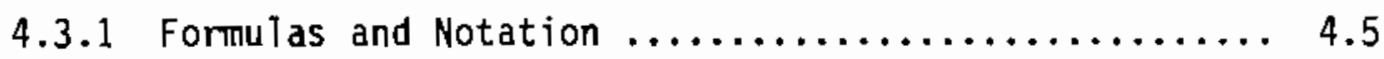

4.3.2 Decay Considerations $\ldots \ldots \ldots \ldots \ldots \ldots \ldots \ldots \ldots \ldots, 4.7$

5.0 PROCEDURES FOR APPLYING ARCL. TO A CONTAMINATED FACILITY $\ldots \ldots \ldots \quad 5.1$

5.1 ACTIVITY 1 - SITE RADIONUCLIDE INVENTORY CALCULATION $\ldots \ldots .5 .3$

5.1.1 Task 1.1 - Identify Primary and Al1 Secondary Facilities within the Site $\ldots \ldots \ldots \ldots \ldots \ldots \ldots \ldots \ldots . . .6 .3$

5.1.2 Task 1.2 - Locate Contamination Within Each Facility and Identify Strata $\ldots \ldots \ldots \ldots \ldots \ldots \ldots \ldots \ldots \ldots, 5.6$

5.1.3 Task 1.3 - Determine Required Number of Samples .... 5.7

5.1.4 Task 1.4 - Collect and Analyze Samples ............ 5.8

5.1.5 Task 1.5 - Compute Mean Concentrations and Associated Statistics $\ldots \ldots \ldots \ldots \ldots \ldots \ldots \ldots \ldots \ldots \ldots \ldots \ldots . . .6$

5.2 ACTIVITY 2 - EXPOSURE SCENARIO SOURCE-TERM PREPARATION .... 5.11

5.2.1 Task 2.1 - Prepare Source Terms for Residential/ Home-Garden Scenario ...................... 5.11

5.2.2 Task 2.2 - Prepare Source Terms for Agricultural

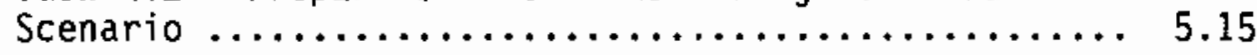

5.2.3 Task 2.3 - Prepare Source Terms for Resource Recycle Scenario ................................. 5.15

5.3 ACTIVITY 3 - RESIDENTIAL/HOME-GARDEN SCENARIO CALCULATION .. 5.17

5.3.1 Task 3.1 - Apply Availability Correction to Radionuclide Dose Factors ................... 5.17 
5.3.2 Task 3.2 - Obtain ResidentiaT/Home-Garden Dose Estimates ................................ 5.18

5.4 ACTIVITY 4 - AGRICULTURAL SCENARIO CALCULATION $\ldots \ldots \ldots \ldots \ldots, 5.24$

5.4.1 Task 4.1 - Apply Availability Correction to Radionuclide Dose Factors for Agricultural

Scenario ................................. 5.24

5.4.2 Task 4.2 - Apply Area Correction to Radionuclide

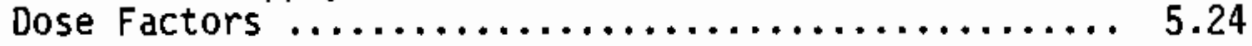

5.4.3 Task 4.3 - Apply Depth Correction to Radionuclide

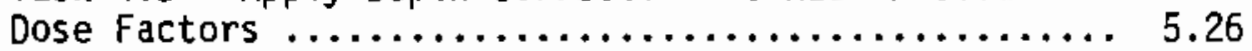

5.4.4 Task 4.4 - Obtain Agricultural Scenario Dose Estimates ............................. 5.29

5.5 ACTIVITY 5 - RESOURCE RECYCLE CALCULATION ............. 5.29

5.5.1 Task 5.1 - Apply Mass Correction to Radionuclide Dose Factors .............................. 5.29

5.5.2 Obtain Resource Recycle Dose Estimates .......... 5.30

5.6 ACTIVITY 6 - SELECTION OF CONTROLLING SCENARIO $\ldots \ldots \ldots \ldots \ldots . .30$

5.6.1 Task 6.1 - Summation of Strata for Each Scenario ... 5.32

5.6.2 Task 6.2 - Summation of Residential/Home-Garden and Agricultural Scenario Doses .................. 5.34

5.6.3 Task 6.3 - Selection of the Most Restrictive Exposure

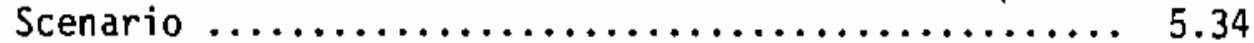

5.7 ACTIVITY 7 - COMPARISON OF CALCULATED DOSES TO STANDARD $\ldots . .5 .34$

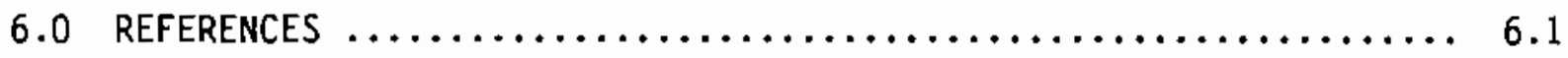

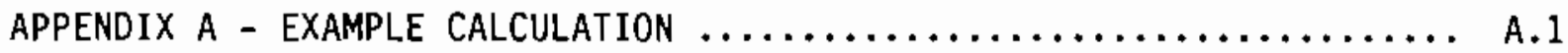
APPENDIX B - COPIES OF THE WORKSHEETS AND TABLES USED FOR PERFORMING ARCL CALCULATIONS $\ldots \ldots \ldots \ldots \ldots \ldots \ldots \ldots \ldots$ B.I 


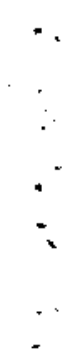




\section{FIGURES}

1.1 Location of the Hanford Site $\ldots \ldots \ldots \ldots \ldots \ldots, \ldots \ldots \ldots, \ldots, \ldots, 1.2$

2.1 Required Activities During an ARCL Calculation $\ldots \ldots \ldots \ldots \ldots, 2.2$

2.2 Crop Root Penetration in the Absence of Barriers $\ldots \ldots \ldots \ldots \ldots .2 .7$

2.3 Allowable Residual Contamination Level Scenario Modification Factors $\ldots \ldots \ldots \ldots \ldots \ldots \ldots \ldots \ldots \ldots \ldots \ldots \ldots \ldots \ldots \ldots \ldots \ldots, 2.8$

5.1 Required Activities During an ARCL Calculation $\ldots \ldots \ldots \ldots \ldots, 5.2$

5.2 Tasks Required to Perform Activity 1 - Site Radionuclide

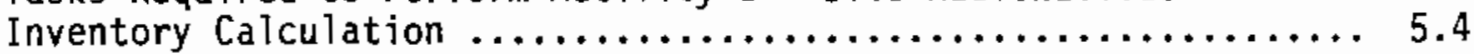

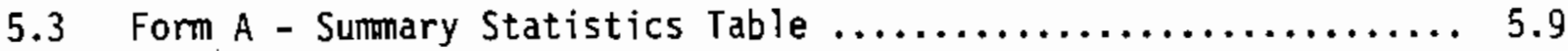

5.4 Tasks Required to Perform Activity 2 - Exposure Scenario Source-Term Preparation ............................... 5.11

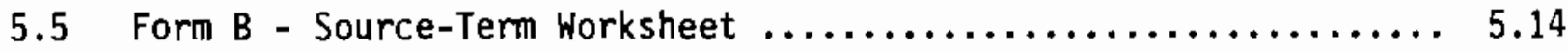

5.6 Tasks Required to Perform Activity 3 - Residential/Home-Garden Scenario Calculation $. . . \ldots \ldots \ldots \ldots \ldots \ldots \ldots \ldots \ldots \ldots \ldots, 5.18$

5.7 Form C - Availability Correction Worksheet ............... 5.19

5.8 Form D - Stratum Dose Calculatio Worksheet ................ 5.20

5.9 Form E - Dose Variance Calculation Worksheet .............. 5.23

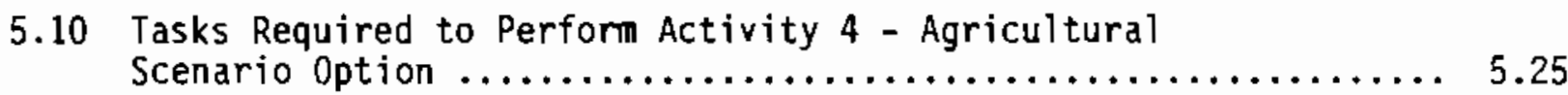

5.11 Form F - Area Correction Worksheet .................... 5.27

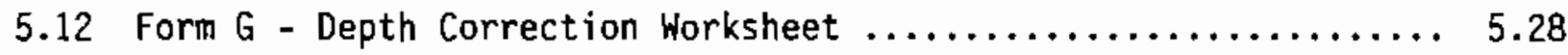

5.13 Tasks Required to Perform Activity 5 - Resource Recycle

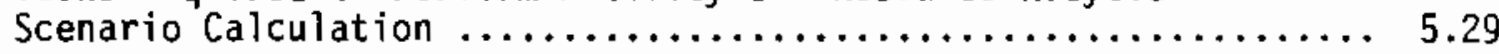

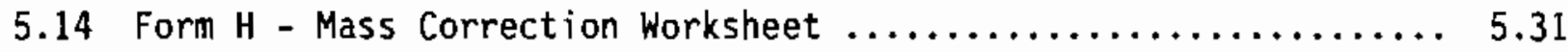

5.15 Tasks Required to Perform Activity 6 - Selection of Controlling Scenario $\ldots \ldots \ldots \ldots \ldots \ldots \ldots \ldots \ldots \ldots \ldots \ldots, 5.32$

5.16 Form I - Final ARCL Worksheet - Summed Over All Strata ........ 5.33

5.17 Task Required to Perform Activity 7 - Comparison of Calculated Doses to Standard ........................... 5.35 


\section{$\underline{\text { TABLES }}$}

2.1 Exposure Pathway Dose Conversion Factors in Units of Effective Dose Equivalent ......................... 2.9

2.2 ARCL Scenario-Specific Dose Conversion Factors in Effective Dose Equivalent rem/yr per pCi/Stratum ............ 2.11

3.1 Additional Scenario Dose Conversion Factors $\ldots \ldots \ldots \ldots \ldots \ldots \ldots . . . . .11$

3.2 Representative Radionuclide Inventory for the Example Site $\ldots \ldots 3.12$

3.3 Relative Dose Rates for the Various Onsite Scenarios for the Example Site Inventory, rem/yr per $\mathrm{pCi} / \mathrm{g}$, at $\mathrm{T}=0 \mathrm{yr} \ldots \ldots \ldots . .12$

3.4 Relative Effective Dose Equivalent Rates for the Various Offsite Scenarios for the Example Site Inventory at $T=0$ yr $\ldots \ldots \ldots \ldots 3.14$

5.1 Worksheets Used for ARCL Analysis of Contaminated Facilities ... 5.3

5.2 Procedures Required for Activity 1, Tasks 1.1 $-1.5 \ldots \ldots \ldots \ldots$

5.3 Procedures Required for Activity 2, Tasks $2.1-2.3 \ldots \ldots \ldots \ldots . . .12$

5.4 Decay Constants for Selected Radionuclides $\left(y r^{-1}\right) \ldots \ldots \ldots \ldots$

5.5 Procedures Required for Activity 3 , Tasks $3.1-3.2 \ldots \ldots \ldots \ldots . \ldots$

5.6 Standard Normal Distribution Values $z 1-\alpha$ Such that $(1-\alpha) 100 \%$ of the Distribution Lies to the Left of $z_{1-\alpha} \ldots \ldots \ldots \ldots \ldots \ldots \ldots .21$

5.7 Procedures Required for Activity 4 , Tasks $4.1-4.4 \ldots \ldots \ldots \ldots .26$

5.8 Procedures Required for Activity 5, Tasks $5.1-5.2 \ldots \ldots \ldots \ldots$

5.9 Procedures Required for Activity 6 , Tasks $6.1-6.3 \ldots \ldots \ldots \ldots . \ldots 52$ 


\subsection{INTRODUCTION}

The Allowable Residual Contamination Level (ARCL) method was developed in 1983 (Kennedy and Napier 1983a; 1983b) to assist the U.S. Department of Energy's (DOE) Richland Operations Office (RL) in decommissioning the retired nuclear production reactors and associated facilities situated on the Hanford Site, located in south-central Washington state (Figure 1.1). The decommissioning operations involve developing the detailed cost, engineering, and safety data necessary to ensure that the final disposition of the retired facilities is performed in an environmentally acceptable manner. Decommissioning a facility in situ (i.e., burying an entire or part of a facility in place) is often an economically attractive alternative. However, a major consideration is determining the amount or level of residual radioactive contamination that can be allowed to remain at a site or facility. In the consideration of decommissioning alternatives, the ARCL method assists by using a site-specific radiation scenario/exposure-pathway analysis, based on an annual radiation dose limit, to determine the acceptable levels of residual radioactive contaminants that can remain in a nuclear facility that is decommissioned in situ.

To permit full consideration of decommissioning alternatives, three specific modes of future use of the land and facilities (i.e., restricted, controlled, and unrestricted) were included in the scope of the method described by Kennedy and Napier (1983a,b). Specific radiation exposure scenarios for individuals who may use the land or facilities after decommissioning were defined and modeled for each mode of future use. For soil contamination and for radioactive material that may be buried in place under stabilized cover materials, both unconfined (surface to a depth of $1 \mathrm{~m}$ ) and confined (subsurface at depths below $1 \mathrm{~m}$ ) conditions were modeled by the radiation exposure scenarios.

After its development in 1983, the ARCL method was adopted as the official analysis method for evaluating decommissioning alternatives of 


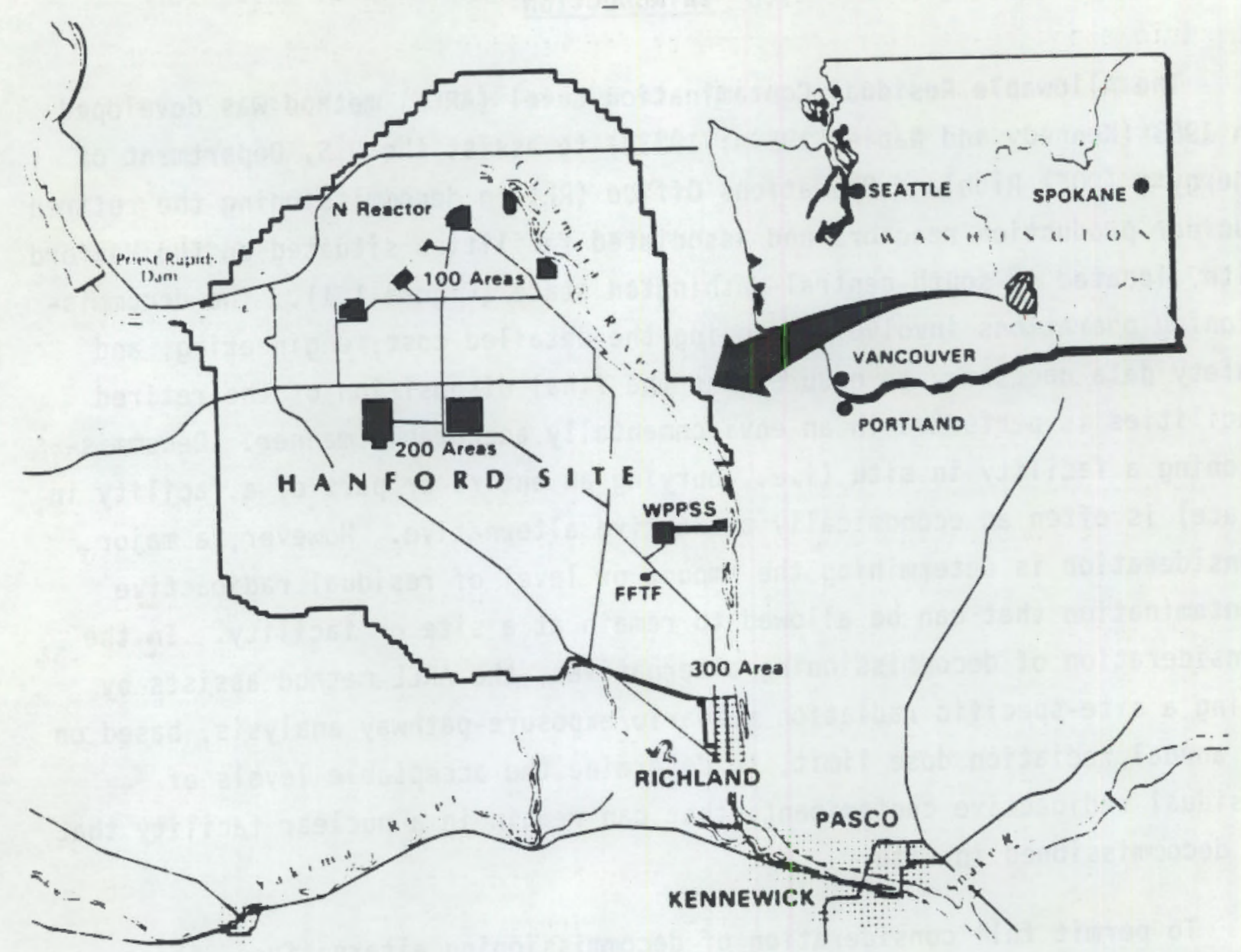

FIGURE 1.1. Location of the Hanford Site

facilities on the Hanford Site.(a) During development of the Hanford 100 Area Long-Range Decommissioning Plan (Adams et a1. 1984) and following initial uses of the ARCL method, questions were raised about the application of the method to site-specific conditions and sampling results for the in situ decommissioning option. To answer these questions, therefore, the original ARCL method was modified, as described in this report, to account for the statistical uncertainties in the radiological sampling and site characterization program, and to make the method easier to apply to field

(a) Letter from Michael J. Lawrence, Manager of the Richland Operations Office of the U.S. Department of Energy, to Hanford Site Contractors, July 3,1984 . 
situations. In particular, the ARCL method was modified to consider scenario/exposure-pathway enhancements for residual radioactive materials in soil, sampling statistics, facility-or site-specific modifications to the method, and adoption of a statistically based decision rule. Step-by-step procedures are also included in this report for the convenience of the user. These procedures may be used in implementing the ARCL method, or other procedures may be developed by the user to fit particular needs.

\subsection{EXISTING DECOMMISSIONING STANDARDS}

In 1981, Mueller, Kennedy, and Soldat conducted a review of soil contamination and existing decomissioning guidance. They concluded that it was difficult to compare the existing soil standards because each was intended for a different situation and because different units or bases were used. Most of the soil contamination information appeared to be consistent with the philosophy of maintaining exposures at levels "as low as reasonably achievable" (ALARA). The U.S. Nuclear Regulatory Commission (NRC) has provided guidance for decommissioning commercial reactors in Regulatory Guide 1.86 (U.S. AEC 1974). However, it has drawbacks in that the guidance values provided in the Guide are not directly comparable to a single dose limit and they are difficult to detect with field instrumentation. Guidance is also provided by NRC (1976) for the release of decontaminated facilities and equipment from by-product, source, or special nuclear material manufacturing. other criteria for operating and/or decommissioning nuclear facilities have been adopted by NRC (Federal Register 1981) and the U.S. EnvironmentaT Protection Agency (EPA) (40 CFR 190; 40 CFR 192).

The Richland Operations Office has adopted a public radiation protection standard of $25 \mathrm{mrem} / \mathrm{yr}$, as estimated using the ARCL method, as the upper limit of dose that a member of the public could potentially receive as a result of decommissioning operations at Hanford. (a) The basic DOE dose limits for protection of the public are being revised to limit exposures of

(a) Letter from Michael J. Lawrence, Manager of the Richland Operations Office of the U.S. Department of Energy, to the Hanford Site Contractors, July 3, 1984. 
5 years or less duration to $500 \mathrm{mrem} / \mathrm{yr}$, and exposures of longer duration to $100 \mathrm{mrem} / \mathrm{yr}$ (DOE 1988). [The method for estimating public radiation exposure has also been revised to consider the effective dose equivalent (EDE) as the official dose-limit unit. The EDE is defined in the International Commission on Radiological Protection (ICRP) Publication No. 26 (ICRP 1977) and is calculated using the dosimetry models described in ICRP Publication No. 30 (ICRP $1979 a, b ; 1980,1981,1982 a, b)]$. In setting this annual dose limit, the Richland Operations Office recognized the importance of the ALARA concept and the potential for individuals who could receive exposures from multiple sources on the Hanford Site. The $25 \mathrm{mrem} / \mathrm{yr}$ dose $1 \mathrm{imit}$ considers both the potential for multiple sources as well as the differences between unrestricted release and continued control of the Hanford Site.

\subsection{HISTORY OF THE ARCL METHOD}

The concepts behind the ARCL method have been under development at Pacific Northwest Laboratory (PNL) for over 12 years. Its first application was as part of a conceptual decommissioning study conducted for the NRC (Schneider and Jenkins 1977). The method was modified as the NRC conceptual decommissioning studies progressed to include a variety of nuclear fuel cycle facilities. These facilities ranged from fuel fabrication plants, to pressurized and boiling water reactors, to low-level waste disposal sites, and independent spent-fuel storage facilities. Example applications of the ARCL method from this early NRC effort to reactors that directly relate to this study are contained in reports by Smith, Konzek, and Kennedy (1978), 0ak et al. (1980), and Konzek et al. (1981).

The ARCL method was modified in 1983 for application specific to the Hanford Site (Kennedy and Napier 1983a,b). These documents include an explanation of the procedures to be used and sample worksheets to assist in performing the calculations for a wide variety of facility conditions and mixtures of radionuclides. The purpose of that effort was to provide a too 1 for the evaluation of decommissioning alternatives for Hanford 100-Area facilities. The results were based on a scenario/exposure-pathway analys is and compliance with an annual dose limit assigned for each of three specific 
modes of future use of the land and facilities. The three modes of future use that were considered were: restricted, controlled, and unrestricted.

Since the documents were published 1983, many assumptions concerning the application of the ARCL method have been standardized. The ARCL Calculations may now be performed assuming a period of institutional control after the facilities are decommissioned to permit stabilization of the site and to allow for radioactive decay of the residual radionuclides. All of the facilities are assumed to be demolished after decontamination so that the "end-use" condition of the facilities and sites is one of contaminated rubble or soil under a layer of clean dirt or some other barrier. In the process of considering decommissioning alternatives using the ARCL method, several questions about applying the method to facility-and site-specific conditions were raised. This document is intended to help answer these questions and to provide enhancements of the original documentation.

\subsection{OVERVIEW OF THE MODIFICATIONS TO THE METHOD}

The original objective of the ARCL method was to help detemine if radioactively contaminated sites require further decontamination or remedial action prior to release (Kennedy and Napier 1983a,b). In accomplishing this objective, the original ARCL method consisted of a screening method to select among decomissioning alternatives. The results of the analysis were also intended to be used to indicate the general magnitude of any remedial actions required prior to release.

Modifications have been made to the original method to account for the sampling statistics associated with the site characterization program and scenario enhancements to make the method more applicable to site-specific analyses. The result is the creation of a revised method that relies more on performance assessment methods than screening methods. The revised ARCL calculations depend on the mixture of radionuclides initially present, the time at which exposure is physically possible, the physical characteristics of each contaminated site, the radiation dose 1 imit (i.e., $25 \mathrm{mrem} / \mathrm{yr}$ ), the sampling statistics associated with the site characterization program, and on the scenarios of possible human exposure to radiation (including both probable levels of exposure and the upper bounds of potential exposure). The 
basic approach to the modified ARCL method is presented in Section 2, and detailed procedures are presented in Section 5.

Finally, the radiation dose conversion factors used for calculating the doses from the inhalation and ingestion pathways have been updated. The dose factors are now presented in terms of "effective whole body dose," using the radiation dosimetry methods described in ICRP Publications 26 and 30 (ICRP $1977 ; 1979 a, b, 1980,1981,1982 a, b)$, along with certain parameters from ICRP Publication 48 (ICRP 1986). This updating simplifies the calculation of these dose factors and brings them into conformance with the rationale used by DOE in developing the $25 \mathrm{mrem} / \mathrm{yr}$ dose limit. 


\subsection{ALLOWABLE RESIDUAL CONTAMINATION LEVEL METHOD}

The primary objective of the Allowable Residual Contamination Level (ARCL) method is to determine if radioactively contaminated sites require further decontamination or remedial action prior to release. A secondary objective is to permit a determination of what remedial actions could be effective. The ARCL method does not choose the most appropriate disposal alternative, nor does it automatically provide the best means of hazard mitigation. The analysis of remedial actions is simply an extended analys is of a site with modified physical characteristics. The general approach for performing ARCL calculations, including expanded consideration of sampling statistics in the site characterization program, is presented in this section.

\subsection{SUMMARY OF THE METHOD}

The general activities required for a complete ARCL application are illustrated in Figure 2.1. Each of these activities is further described in Sections 5.1 through 5.7 of this report. Each of the seven basic activities is comprised of from one to five tasks; each task, in turn, is composed of from one to eight procedures. A total of 25 separate procedures are detailed in a step-by-step manner. To aid in many of the procedures, worksheets are illustrated and explained in Section 5.

Preparation of a comprehensive site radionuclide inventory is the necessary first activity. This activity includes sampling and monitoring procedures that are outside the scope of this manual, but mention is made of where these tasks fit into the entire process.

The radionuclide inventory is adjusted in the second activity for application to each of the three controlling exposure scenarios. This adjustment can include corrections for radioactive decay if the proposed action is not immediate decontamination and release of the facility.

The calculation of individual radiation doses can proceed concurrently for the three major exposure scenarios, as illustrated in Figure 2.1. Calculation of the doses can include consideration of waste form availability, areal distribution, depth, decay, and mass of recyclable metals. 


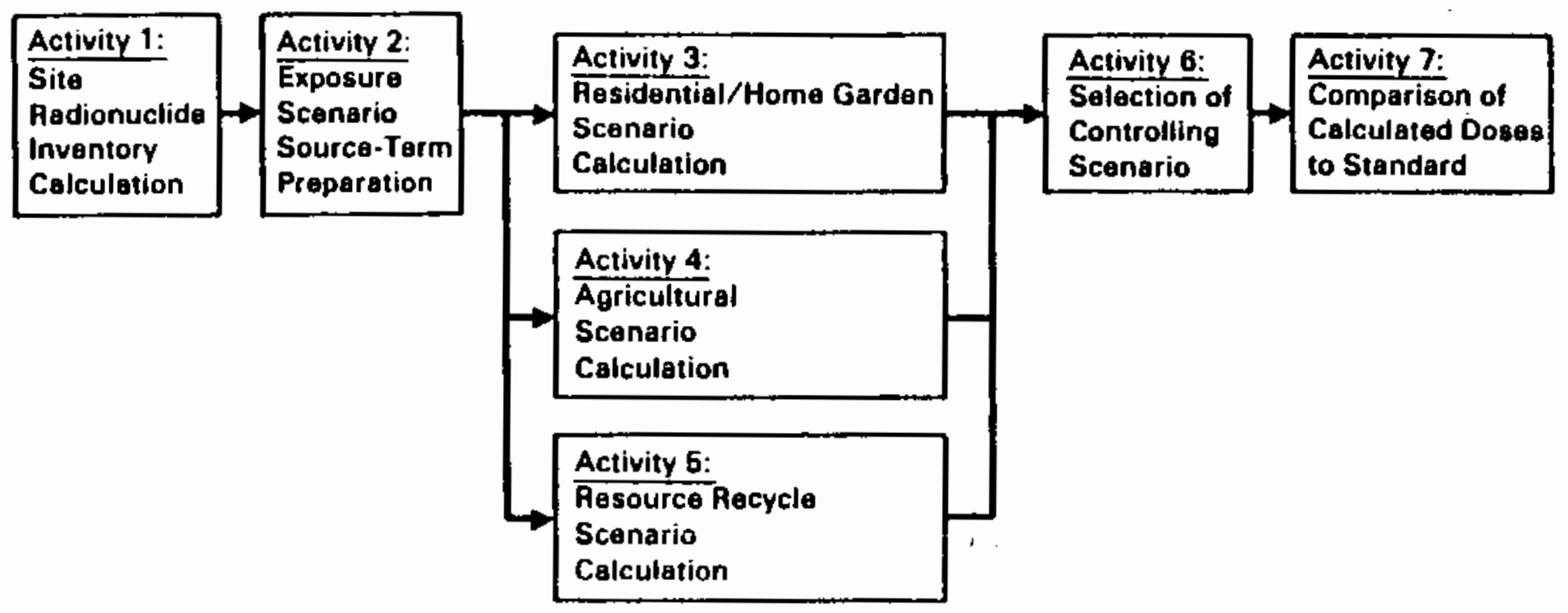

FIGURE 2.1. Required Activities During an ARCL Calculation 
The dose estimates from the Residential/Home-Garden and Agricultural scenarios are then summed and the sum compared to the resource recycle result. The most restrictive dose is then compared to the mandated dose limit (i.e., $25 \mathrm{mrem} / \mathrm{yr}$ ) to determine if the proposed decommissioning alternative is acceptable. In all calculations, the sampling variability and covariability of the measured radionuclide concentrations may be propagated, and the finat answer may be phrased in terms of the Upper Confidence Limit.

Careful completion of each of the seven activities will provide a completely documented analysis of the final site disposal alternative, which should prove to be of great benefit to the Hanford decommissioning program.

\subsection{SCENARIO DESCRIPTIONS}

The use of the ARCL method for decomissioning the facilities on the Hanford Site is based on an evaluation of the potential radiation exposures resulting from specific "end-use" conditions of residual soil contamination. Radiation exposures are based upon representative scenarios and the measured mixtures of radionuclides present. These scenarios are designed to estimate the exposure conditions for individuals who could live on a decommissioned site after loss of institutional controls after decomassioning. The exposure scenarios include the radiation exposure pathways that are most likely for individuals who may actively contact residual radiative materials. The basic scenarios considered in the ARCL method for residual contamination associated with demolished facilities are: 1) the Resource Recycle Scenario, 2) the Residential/Home-Garden Scenario, and 3) the Agricultural Scenario. Full descriptions of these scenarios are given in the following sections.

\subsubsection{Resource Recycle Scenario}

This exposure scenario is designed to represent the potential activities of an individual engaged in recycling materials recovered during salvage operation in the buried rubble left after demolition of a facility. Because loss of institutional controls is postulated after decommissioning, it is assumed that an individual is free to salvage anything that may be of economic value at the site. The previous studies in this series (Kennedy and Napier 1983a,b) defined two scenarios for this situation: 1) the resource salvage scenario and 2) the resource recycle scenario. For standard assumed 
conditions, they showed that the resource recycle scenario resulted in higher doses to an individual than did the resource salvage scenario. Therefore, for the purpose of this revised analysis, only the resource recycle scenario is considered further.

Data presented in the Draft Environmental Impact Statement Concerning Proposed Rulemaking Exemption From Licensing Requirements for Smelted Alloys Containing Residual Technetium-99 and Low-Enriched Uranium (U.S. NRC 1980), indicate that the operations with the greatest potential dose rate (i.e., annual dose) to an individual occur during smelting and manufacture of consumer products. During these operations, the worker in a smelter or foundry is exposed to piles of metal scrap, metal ingots, and accumulated finished products. He is additionally exposed to metal fumes and particulates. Radiation dose factors for these operations have been prepared by 0'Donnell et al. (1978) for a study of dose to man from recycle of metals reclaimed from decommissioned nuclear power plants. From the information in this reference, it appears that the individual with the greatest potential for exposure is one working in a metal scrap yard.

The dose to a worker during material recycle is directly dependent on the quantity of material assumed to be recovered. The individual in the resource salvage scenario is assumed to work $2000 \mathrm{~h} / \mathrm{yr}$. The market price for scrap iron is assumed to be about $\$ 0.09 / \mathrm{kg}$, so for the individual to make a reasonable income, he would need to recover nearly $200 \mathrm{Mg} / \mathrm{yr}$ of scrap iron (about $1 \mathrm{Mg} /$ day). This quantity of material is assumed to be melted and made into consumer products. A factory worker is assumed to work in a scrap yard, as described in 0'Donnell et al. (1978), and to be exposed to the inhalation threshold limit value (TLV) of metal particulates $\left(5 \mathrm{mg} / \mathrm{m}^{3}\right)$ for a period long enough to process $200 \mathrm{Mg}$ of recovered material.

\subsubsection{Residential/Home-Garden Scenario}

This scenario is designed to represent the unrestricted use of a decommissioned site by an individual who resides there and engages in home gardening activities for 50 years. When the individual moves onto the site, he is assumed to construct a basement with a volume of $1.000 \mathrm{~m}^{3}$ (dimensions of $20 \times 10 \times 5 \mathrm{~m})$. For purposes of determining if the inventory of radioactive materials will result in an annual dose rate less than $25 \mathrm{mrem} / \mathrm{yr}$, the 
basement is located in an area where the greatest (or worst) radionuclide inventory associated with the particular facility being evaluated would occur. All of the contamination present in this volume is assumed to be uniformly mixed with the clean soil in the volume and the resulting material is spread to a depth of $15 \mathrm{~cm}$ over about two-thirds of a hectare. This part of the scenario is similar to the intruder-construction scenario developed by the $N R C$ in the Draft Environmental Impact Statement in support of 10 CFR Part 61 (U.S. NRC 1981). After the house is constructed, the individual is assumed to spend $12 \mathrm{~h} / \mathrm{d}$ outdoors on the site, during which time he is exposed to direct penetrating radiation from the soil. The individual is also assumed to inhale resuspended contamination in the surface soil for $12 \mathrm{~h} / \mathrm{d}$ during his 50 years of exposure, with an air concentration calculated using a mass loading factor of $10^{-4} \mathrm{~g} / \mathrm{m}^{3}$ air (Napier et al. 1984).

Radionuclides contained in activated metals are not immediately available for resuspension or plant-root contact. For small pieces of metal with little intrinsic value (i.e., those that would not be considered in the resource recycle scenario), a reduction factor (RF) can be defined as the ratio of the mass of metal that has corroded at a certain time to the original mass. For plates or tubes of material, this can be written as

$$
R F=2 t \text { (corrosion rate, cm/ } / \mathrm{r} r) /(\text { thickness, } c m)
$$

where $t$ is the time period of interest. The corrosion rate used is the uniform corrosion rate, which can be thought of as a total rate, expressed in $\mathrm{cm} / \mathrm{yr}$ of surface. Many materials experience pitting corrosion, expressed in terms of weight loss per year. For the purposes of this analysis, pitting corrosion rates can be converted to equivalent uniform rates because only the total mass involved is of interest.

Uniform corrosion rates of $0.01 \mathrm{~cm} / \mathrm{yr}$ and $0.001 \mathrm{~cm} / \mathrm{yr}$ are used for carbon and stainless steels, respectively (0ztunali and Roles 1986), and $0.001 \mathrm{~cm} / \mathrm{yr}$ for aluminum by analogy to stainless steel (Mackenzie et al. 1985) . 
Finally, the individual is assumed to grow $25 \%$ of his fruit and vegetable diet in a backyard garden that is located in the soil contaminated from the excavation.

\subsubsection{Agricultural Scenario}

The agricultural scenario is defined to account for the potential exposure to an individual from ingesting agricultural products whose roots penetrate into buried radioactive materials. The contaminated material could be either deeply buried (at a depth of $5 \mathrm{~m}$ or greater) or buried closer to the surface in the near vicinity of facilities under consideration through the residential/home-garden (basement) scenario. This scenario is similar to the root penetration scenario previously defined in the original ARCL method (Kennedy and Napier 1983a,b) for confined materials buried $5 \mathrm{~m}$ or greater from the surface. The only pathway of radiation exposure in this scenario is the ingestion of agricultural products containing radionuclides. The maximum exposed individual is assumed to obtain $25^{\circ}$ of his fruit and vegetable diet from this food source. Because of the limited size of the contaminated areas, animal products have been excluded from this scenario. In this application, the depth of the buried materials is used to obtain a root penetration factor. This factor accounts for the fraction of the plant roots that penetrate below a given depth. This factor is then used as a multiplier to effectively reduce the root uptake of radionuclides from the soil and thus reduce the concentration of radionuclides in the plants. Figure 2.2 shows the crop root penetration factor as a function of depth as obtained from Napier (1982).

This scenario is based on the assumption that the site is of large enough size (maximum of $1 \mathrm{ha}$ ) to account for $25 \%$ of the fruit and vegetable diet. To account for small sites of radioactive contamination, an area correction factor for this scenario is next defired. To produce one quarter of the fruit and vegetable diet, it is estimated that the site would have to occupy an area of at least 0.1 ha. This value is based on the following estimates for the general area required to produce food products, assuming rather intensive gardening practices: 1) about $50 \mathrm{~m}^{2}$ would be required to raise leafy and other above-ground vegetables, 2) about $200 \mathrm{~m}^{2}$ would be required for root vegetables and grains, and 3) somewhat over $200 \mathrm{~m}^{2}$ would be 


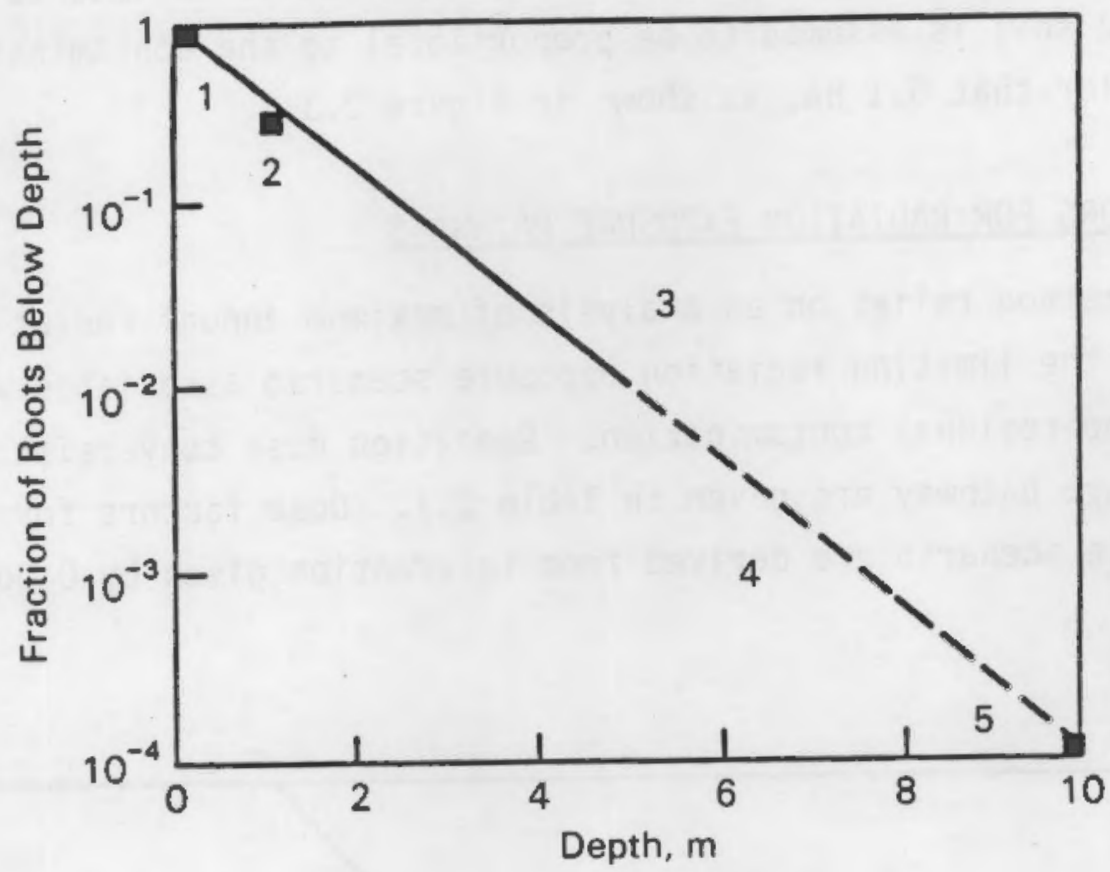

LEGEND

1. $100 \%$ of plant roots are assumed to be at or below the soil surface.

2. $70 \%$ of alfalfa roots are in the top 1 meter (Washington State University 1970).

3. Soil line adapted from results for cumulative percent frequency of rooting depth for 1,012 vascular plants as reported by Foxx et al. (1985).

4. Extrapolation of Point 3 (dashed line).

5. Arbitrary 10-meter cutoff.

FIGURE 2.2. Crop Root Penetration in the Absence of Barriers

required for fruit trees (Kennedy et al. 1986). Of course, these estimates would vary depending upon the agricultural methods used and the climatic conditions encountered. It is suggested by these general estimates that 0.1 ha would be sufficient for producing $25 \%$ of the plant food diet for a family of 
four. Thus, the fraction of the plant food diet that is assumed to be grown in contaminated soil is assumed to be proportional to the contaminated area for sites smaller that 0.1 ha, as shown in Figure 2.3.

\subsection{DOSE FACTORS FOR RADIATION EXPOSURE PATHWAYS}

The ARCL method relies on an analysis of maximum annual radiation doses resulting from the limiting radiation exposure scenario associated with the "end-use" of the residual contamination. Radiation dose conversion factors for each exposure pathway are given in Table 2.1. Dose factors for the resource/recycle scenario are derived from information given by $0^{\prime}$ Donnell et al. (1978).

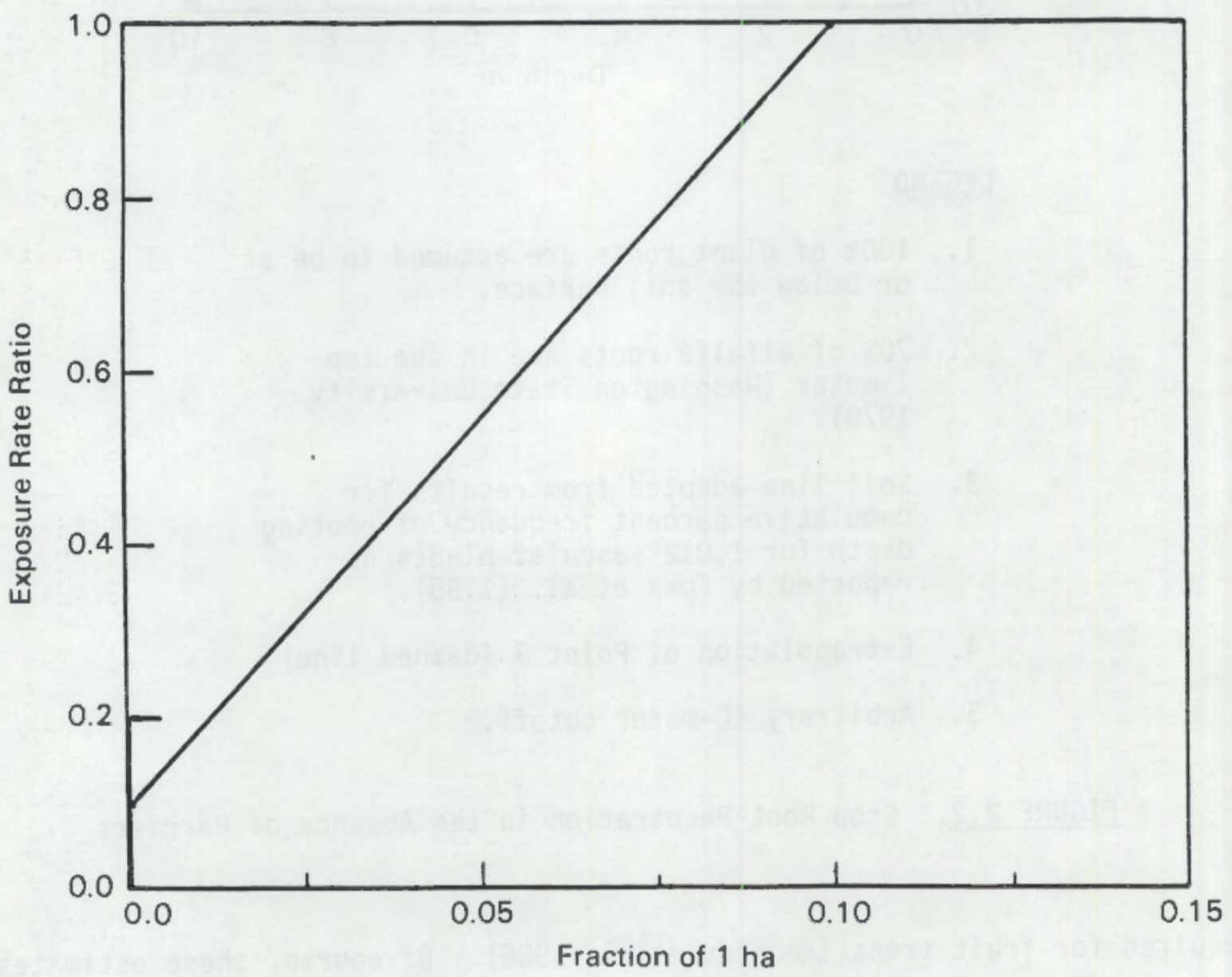

FIGURE 2.3. Allowable Residual Contamination Level Scenario Modification Factors 
IABLE 2.1. Exposure Pathway Dose Conversion Factors in Units of Effective Dose Equivalent

Radionuclide
${ }_{14}^{3 \mathrm{H}}$

$36 \mathrm{Cl}$

$57 \mathrm{Co}$

$60 \mathrm{Co}$

$55 \mathrm{Fe}$

$59 \mathrm{Fe}$

$59 \mathrm{Ni}$

$63 \mathrm{Ni}$

$90 \mathrm{~S} r+\mathrm{D}$

$93 \mathrm{Mo}$

$94 \mathrm{Nb}$

$99 \mathrm{Tc}$

$124 \mathrm{Sb}$

$125 \mathrm{Sb}+\mathrm{D}$

$134 \mathrm{Cs}$

$135 \mathrm{Cs}$

$137 \mathrm{C}_{5}+\mathrm{D}$

${ }^{144} \mathrm{Ce}+\mathrm{D}$

152Eu

$154 \mathrm{Eu}$

226 Ra

232Th

$235 \mathrm{U}+\mathrm{D}$

$238 \mathrm{U}+\mathrm{D}$

$237 \mathrm{~Np}+\mathrm{D}$
$238 \mathrm{Pu}$
$239 \mathrm{Pu}$

$241_{\text {Am }}$
Resource-Recycle (rem/yr per $\mathrm{pCi} / \mathrm{m}^{2}$ Surface Area)

3. $\overline{1 \mathrm{E}}-15$

2.7E-14

2.7E-11

$4.2 \mathrm{E}-10$

$7.1 E-15$

1. $5 \mathrm{E}-10$

$3.8 \mathrm{E}-14$

$3.8 \mathrm{E}-14$

$4.0 \mathrm{E}-12$

2.7E-11

$2.4 E-10$

3. $3 \mathrm{E}-15$

$2.7 \mathrm{E}-10$

$6.7 \mathrm{E}-11$

$2.4 E-10$

$1.3 \mathrm{E}-13$

$1.0 \mathrm{E}-10$

$8.7 \mathrm{E}-11$

$1.8 \mathrm{E}-10$

$1.9 \mathrm{E}-10$

$6.7 \mathrm{E}-11$

3. $9 \mathrm{E}-11$

2.0E-11

1.2E-11

$1.5 \mathrm{E}-9$

9. $3 \mathrm{E}-10$

$1.0 \mathrm{E}-9$

8.9E-10 $\frac{\text { Contaminated Soil (rem/yr per } \mathrm{pCi} / \mathrm{g} \text { soil) }}{\text { Inhalation of }}$ Resuspended Soil and External Exposure from Ground/Surface Shine

3.6E-11

$6.1 \mathrm{E}-9$

7.0E-7

2.0E-4 Ingestion-Internal

Exposure Only

$6.4 \mathrm{E}-3$

$8.8 E-8$

$2.9 E-3$

$4.7 \mathrm{E}-5$

$4.6 \mathrm{E}-5$

$2.3 \mathrm{E}-3$

1.1E-6

$1.5 \mathrm{E}-5$

$3.8 \mathrm{E}-8$

$3.5 \mathrm{E}-7$

$1.1 E-7$

$1.0 E-9$

$1.6 \mathrm{E}-5$

$5.7 \mathrm{E}-7$

1.5E-6

$4.1 \mathrm{E}-3$

$3.0 \mathrm{E}-7$

$3.9 \mathrm{E}-3$

2. $9 \mathrm{E}-5$

1.1E-5

$4.5 \mathrm{E}-8$

$5.1 \mathrm{E}-4$

$5.2 E-3$

$1.2 E-3$

4. $4 \mathrm{E}-3$

1.5E-5

5. $1 E-6$

2.1E-5

$1.3 \mathrm{E}-8$

$1.5 \mathrm{E}-3$

$1.4 \mathrm{E}-4$

2. $1 \mathrm{E}-6$

$1.5 \mathrm{E}-5$

$1.6 \mathrm{E}-6$

3. $0 E-3$

$3.1 \mathrm{E}-3$

$5.2 \mathrm{E}-3$

2.6E-6

3.7E-6

$6.4 E-2$

$7.4 \mathrm{E}-3$

$2.4 E-3$

$1.1 \mathrm{E}-5$

$1.8 \mathrm{E}-7$

1. $0 \mathrm{E}-4$

2.1E-3

$1.4 \mathrm{E}-5$

$1.6 \mathrm{E}-5$

1. $3 E-4$

1. $5 \mathrm{E}-4$ 
The PNL-developed computer program GENII (Napier et al. 1988) was used to calculate dose conversion factors for continuous exposures. For inhaled particles, a particle size of $1 \mu m$ activity-median aerodynamic diameter (AMAD) is assumed. This particle size is within the respirable size distribution and is a "standard" assumption used in inhalation dose calculations when detailed information on the particle size distribution is not available. Dose factors for external exposures to contaminated soil are obtained from the ISOSHLD (Enge1, Greenborg, and Hendrickson 1966; Simmons et al. 1967) computer program. Table 2.1 shows the combined inhalation and external exposure dose conversion factors for surface soil contamination obtained from the GENII computer program in units of rem/yr per $\mathrm{pCi} / \mathrm{g}$. These factors include consideration of $12-h / d$ exposure. A listing of the exposure pathway doseconversion factors for the ingestion pathway is also given in Table 2.1. These represent the dose factors for an infinite plane slab of contamination $15 \mathrm{~cm}$ deep, which leads to contamination of $25 \%$ of the individual's diet.

\subsection{SCENARIO-SPECIFIC DOSE CONVERSION FACTORS}

By applying the exposure conditions defined for the radiation exposure scenarios, scenario-specific dose conversion factors for the combined pathways of each scenario are next calculated. These scenario-specific dose conversion factors are calculated using the pathway dose factors shown in Table 2.1 and are listed in Table 2.2. For the recycle pathway, the external dose conversion factors are in units of $\mathrm{rem} / \mathrm{yr}$ per $\mathrm{pCi} / \mathrm{m}^{2}$ of contaminated surface, adjusted to a recycle rate of $200 \mathrm{Mg} / \mathrm{yr}$, as described in Section 2.2.1. These factors are taken from 0'Donne $i 1$ et al. (1978) and are shown by radionuclide in Table 2.1. The dose factors for the recycle scenario are in units of rem/yr per pCi in $200 \mathrm{Mg}$ of contaminated metal, the residential/ home-garden scenario dose factors are in units of rem/yr per $\mathrm{pCi}$ in the excavated soil spread over about 0.67 ha, and the agricultural scenario dose factors are in units of $\mathrm{rem} / \mathrm{yr}$ per $\mathrm{pCi}$ in soil distributed over 1 ha. Scenario dose conversion factors are suppliec for a listing of 28 radionuclides of potential importance to decommissioning operations on the Hanford Site. 
TABLE 2.2. ARCL Scenario-Specific Dose Conversion Factors in Effective Dose Equivalent rem/yr per $\mathrm{pCi}$ /Straturn

Scenario (rem/yr per $\mathrm{pCi} /$ Stratum)

\begin{tabular}{|c|c|c|c|c|}
\hline $\begin{array}{l}\text { Radio- } \\
\text { nuclide }\end{array}$ & $\begin{array}{l}\text { Resource-Recycle } \\
\text { External, Inhala- } \\
\text { tion \& Ingestion } \\
\end{array}$ & $\begin{array}{l}\text { Residenti } \\
\text { External \& } \\
\text { Inhalation } \\
\end{array}$ & Inqestion(a) & $\begin{array}{l}\text { Agricultural } \\
\text { Ingestion(b) }\end{array}$ \\
\hline $\begin{array}{l}3 \mathrm{H} \\
14 \mathrm{C} \\
36 \mathrm{Cl} \\
57 \mathrm{Co}\end{array}$ & $\begin{array}{l}1 . \overline{\mathrm{E}}-19 \\
1.4 \mathrm{E}-17 \\
1.4 \mathrm{E}-14\end{array}$ & $\begin{array}{l}2.4 \mathrm{E}-20 \\
4.1 \mathrm{E}-18 \\
4.7 \mathrm{E}-16 \\
1.3 \mathrm{E}-13\end{array}$ & $\begin{array}{l}3.1 \mathrm{E}-14 \\
3.1 \mathrm{E}-14 \\
1.5 \mathrm{E}-12 \\
7.3 \mathrm{E}-16\end{array}$ & $\begin{array}{l}2.1 \mathrm{E}-14 \\
2.1 \mathrm{E}-14 \\
1.0 \mathrm{E}-12 \\
4.9 \mathrm{E}-16\end{array}$ \\
\hline $\begin{array}{l}60 \mathrm{Co} \\
55 \mathrm{Fe} \\
59 \mathrm{Fe}\end{array}$ & $\begin{array}{l}2.1 \mathrm{E}-13 \\
3.6 \mathrm{E}-18 \\
7.5 \mathrm{E}-14\end{array}$ & $\begin{array}{l}4.3 \mathrm{E}-12 \\
5.9 \mathrm{E}-17 \\
1.9 \mathrm{E}-12\end{array}$ & $\begin{array}{l}1.0 \mathrm{E}-14 \\
2.5 \mathrm{E}-17 \\
2.3 \mathrm{E}-16\end{array}$ & $\begin{array}{l}6.7 \mathrm{E}-15 \\
1.7 \mathrm{E}-17 \\
1.5 \mathrm{E}-16\end{array}$ \\
\hline $\begin{array}{l}59 \mathrm{Ni} \\
63 \mathrm{Ni} \\
90 \mathrm{Sr}+\mathrm{D}\end{array}$ & $\begin{array}{l}1.9 \mathrm{E}-17 \\
1.9 \mathrm{E}-17 \\
2.0 \mathrm{E}-15\end{array}$ & $\begin{array}{l}7.3 \mathrm{E}-17 \\
6.7 \mathrm{E}-19 \\
1.1 \mathrm{E}-14\end{array}$ & $\begin{array}{l}3.8 \mathrm{E}-16 \\
1.0 \mathrm{E}-15 \\
2.7 \mathrm{E}-12\end{array}$ & $\begin{array}{l}2.5 \mathrm{E}-16 \\
6.7 \mathrm{E}-16 \\
1.8 \mathrm{E}-12\end{array}$ \\
\hline $\begin{array}{l}93 \mathrm{Mo} \\
94 \mathrm{Nb} \\
99 \mathrm{TC}\end{array}$ & $\begin{array}{l}1.4 \mathrm{E}-14 \\
1.2 \mathrm{E}-13 \\
1.7 \mathrm{E}-18\end{array}$ & $\begin{array}{l}2.0 \mathrm{E}-16 \\
2.6 \mathrm{E}-12 \\
3.0 \mathrm{E}-17\end{array}$ & $\begin{array}{l}1.9 \mathrm{E}-14 \\
7.3 \mathrm{E}-15 \\
3.4 \mathrm{E}-13\end{array}$ & $\begin{array}{l}1.3 \mathrm{E}-14 \\
4.9 \mathrm{E}-15 \\
2.3 \mathrm{E}-13\end{array}$ \\
\hline $\begin{array}{l}124 \mathrm{Sb} \\
125 \mathrm{Sb}+\mathrm{D} \\
134 \mathrm{Cs}\end{array}$ & $\begin{array}{l}1.4 \mathrm{E}-13 \\
3.4 \mathrm{E}-14 \\
1.2 \mathrm{E}-13\end{array}$ & $\begin{array}{l}3.5 \mathrm{E}-12 \\
8.0 \mathrm{E}-13 \\
2.9 \mathrm{E}-12\end{array}$ & $\begin{array}{l}1.0 \mathrm{E}-14 \\
3.4 \mathrm{E}-15 \\
1.4 \mathrm{E}-14\end{array}$ & $\begin{array}{l}6.7 \mathrm{E}-15 \\
2.3 \mathrm{E}-15 \\
9.3 \mathrm{E}-15\end{array}$ \\
\hline $\begin{array}{l}135 \mathrm{Cs} \\
137 \mathrm{Cs}+\mathrm{D} \\
144 \mathrm{Ce}+\mathrm{D}\end{array}$ & $\begin{array}{l}6.5 \mathrm{E}-17 \\
5.0 \mathrm{E}-14 \\
4.4 \mathrm{E}-15\end{array}$ & $\begin{array}{l}8.7 \mathrm{E}-18 \\
1.0 \mathrm{E}-12 \\
9.3 \mathrm{E}-14\end{array}$ & $\begin{array}{l}1.4 \mathrm{E}-15 \\
1.0 \mathrm{E}-14 \\
1.1 \mathrm{E}-15\end{array}$ & $\begin{array}{l}9.3 \mathrm{E}-16 \\
6.7 \mathrm{E}-15 \\
7.1 \mathrm{E}-16\end{array}$ \\
\hline $\begin{array}{l}152 \mathrm{Eu} \\
154 \mathrm{Eu} \\
226 \mathrm{Ra}\end{array}$ & $\begin{array}{l}9.0 \mathrm{E}-14 \\
9.5 \mathrm{E}-14 \\
3.4 \mathrm{E}-14\end{array}$ & $\begin{array}{l}2.0 \mathrm{E}-12 \\
2.1 \mathrm{E}-12 \\
3.5 \mathrm{E}-12\end{array}$ & $\begin{array}{l}1.7 \mathrm{E}-15 \\
2.5 \mathrm{E}-15 \\
4.3 \mathrm{E}-11\end{array}$ & $\begin{array}{l}1.2 \mathrm{E}-15 \\
1.6 \mathrm{E}-15 \\
2.8 \mathrm{E}-11\end{array}$ \\
\hline $\begin{array}{l}232 \mathrm{Th} \\
235 \mathrm{U}+\mathrm{D} \\
238 \mathrm{U}+\mathrm{D}\end{array}$ & $\begin{array}{l}2.0 \mathrm{E}-14 \\
1.0 \mathrm{E}-14 \\
6.0 \mathrm{E}-15\end{array}$ & $\begin{array}{l}4.9 \mathrm{E}-12 \\
1.7 \mathrm{E}-13 \\
6.7 \mathrm{E}-14\end{array}$ & $\begin{array}{l}1.6 \mathrm{E}-12 \\
7.3 \mathrm{E}-15 \\
1.2 \mathrm{E}-16\end{array}$ & $\begin{array}{l}1.1 \mathrm{E}-12 \\
4.9 \mathrm{E}-15 \\
8.0 \mathrm{E}-17\end{array}$ \\
\hline $\begin{array}{l}237 \mathrm{~Np}+\mathrm{D} \\
238 \mathrm{pu} \\
239 \mathrm{pu}\end{array}$ & $\begin{array}{l}7.5 \mathrm{E}-13 \\
4.7 \mathrm{E}-13 \\
5.0 \mathrm{E}-13\end{array}$ & $\begin{array}{l}5.7 \mathrm{E}-13 \\
8.0 \mathrm{E}-14 \\
8.7 \mathrm{E}-14\end{array}$ & $\begin{array}{l}1.4 \mathrm{E}-12 \\
9.3 \mathrm{E}-15 \\
1.1 \mathrm{E}-14\end{array}$ & $\begin{array}{l}9.3 \mathrm{E}-13 \\
6.2 \mathrm{E}-15 \\
7.1 \mathrm{E}-15\end{array}$ \\
\hline $241_{A m}$ & $4.5 \mathrm{E}-13$ & $1.3 \mathrm{E}-13$ & $1.0 \mathrm{E}-13$ & $6.7 \mathrm{E}-14$ \\
\hline
\end{tabular}

(a) Based on the activity of the respective radionuclides in the top $15 \mathrm{~cm}$ of soil within an area of 0.67 hectare; no correction for depth should be applied.

(b) Based on the activity of the respective radionuclides in the top $15 \mathrm{~cm}$ of soil over an area of 1.0 hectare; can be adjusted for depth and area of contamination. 



\subsection{EXPOSURE SCENARIOS CONSIDERED BUT DISMISSED}

The Allowable Residual Contamination Level (ARCL) method for decommissioning nuclear facilities depends on the comparison of an annual radiation dose limit to a calculated annual dose conmitment. The calculated dose used in the comparison is the maximum from a suite of scenarios designed to provide estimates of dose to a maximally exposed individual. In the development of the original ARCL technique (Kennedy and Napier 1983a,b), the scenarios chosen for detailed analysis were those involving human intrusion into and/or interaction with the residual radioactive material. Certain other scenarios were discarded after initial analyses indicated that they were not limiting (i.e., that they did not result in the highest dose rate). This section provides additional detail on the scenarios that were discarded and compares dose factors for them to dose factors for the scenarios that were retained.

\subsection{ADDITIONAL INTRUDER SCENARIO PATHWAY DESCRIPTIONS}

The potential routes through which people may be exposed to radionuclides or radiation are called "exposure pathways." The general pathways can be thought of as external exposure, inhalation, and ingestion. Doses from external exposure result from direct radiation from air, water, soil, and contaminated structures. Doses from inhalation can result from breathing aerosols released from facilities or from materials resuspended from soils. Ingestion doses are from consumption of water, fish, waterfowl, game, food crops, animal products, or direct consumption of small amounts of material transferred from contaminated surfaces to the hands. The ARCL method used for individual sites is based on the sum of exposures through all the selected pathways in a radiation exposure scenario analysis.

The key to the ARCL method is an analysis of the maximum annual radiation dose an individual could receive, which is calculated by summing the doses from many exposure pathways. The pathways are chosen depending on the potential ways an individual could be exposed to residual radionuclides for each condition that could exist after decommissioning. The collection of 
appropriate pathways is called an "exposure scenario." The ability of the user of the method to choose the exposure scenario is what gives the ARCL method the flexibility to handle many types of sites, inventories, and locations.

For release of facilities for unrestricted use, the following general types of potential exposure scenarios were investigated:

- transient

- permanent resident

- offsite populations

- well drilling, excavation

- contact with soil, inhalation of resuspended material

- drinking of well water

- transport in the environment by plants and animals (biotic transport)

- backyard garden

- inadvertent intruder

- intentional intruder

- resource recovery

- recovered resource use.

As described in Section 2, the detailed composite scenarios of resource recycle, residential home gardening, and agriculture in contaminated soil are used as the limiting scenarios for unrestricted release of soil and facilities. Those scenarios are compared here to biotic transport and groundwater transport scenarios for several conditions. This comparison is provided to illustrate the degree to which the intruder scenarios are the most important. Also given are potential doses to individuals and populations out of the immediate vicinity of the wastes. These doses are included to illustrate the strength of the conclusion that the dose to the orrite individual is indeed the limiting dose. No attempt is made to consider the additive effects of more than one scenario occurring at a time. There are three reasons for 
this: 1) several of the scenarios are mutually exclusive (i.e., biotic transport by native plants versus agricu1ture); 2) the scenarios consider effects that occur at different times (i.e., intrusion versus long-term transport); and 3 ) the scenarios are designed to affect different individuals involved in different activities (i.e., residents, farmers, offsite members of the pub1ic). Furthermore, since $100 \%$ of the radionuclide inventories are assumed to be involved with each scenario, addition would result in "double counting" of the impacts.

\subsubsection{Biotic Transport Scenario}

Transport of buried radioactive material to the soil surface by indigenous plants and animals is a very slow process, but continued over long periods, it may result in substantial exposure to humans from unprotected waste sites. At Hanford, biotic transport has resulted in "nuisance" contamination from past practices. The overall processes of waste- form degradation, followed by plant or animal uptake, are relatively poorly understood, but are continuing to be researched. A preliminary model of biotic transport processes has recently been developed (McKenzie et al. 1982a,b; Kennedy, Cadwe11, and McKenzie 1985). This model indicates that, for low-level radioactive waste disposal sites without barriers to prevent intrusion by plants and animals, the quantity of radionuclides transported to the soil surface can be significant compared to other pathways. A simplified version of the McKenzie model was implemented in the code GENII (Napier et al. 1988) to develop appropriate dose conversion factors.

Following release of site control, a plant and animal community representative of arid, western sites is assumed to establish itself over the wastes. The description of the biotic community is taken from McKenzie et al. (1982b). To illustrate the variability of biotic transport with depth of clean cover, both 1-m- and 5-m-thick overburdens are modeled.

The human exposure assumptions used in the calculations are the same as those used in the residential/home garden scenario. After a period of biotic transport, an individual is assumed to move on to the land and grow a garden in the soil. The individual residing on the site contaminated under the biotic transport scenario is exposed through three pathways: inhalation of resuspended dusts, ingestion of crops grown in the soil, and direct 
exposure. Initially, the radionuclides preferentially moved by biotic transport are those readily taken up by plants. At longer times, the doses

tend to come from the less mobile, but longer-lived nuclides, such as ${ }^{239} \mathrm{Pu}$, through resuspension. Therefore, the values used in the comparisons are the maxima noted in the initial $100-y r$ period.

Only localized concentrations of radionuclides are expected near the waste sites; once the material is brought to the surface, normal erosion processes would tend to disperse it. The effects of this scenario on populations also depend directly on the number of people assumed to be living on the site.

\subsubsection{Ground-Water Migration Scenario}

Leaching of radionuclides from soil or buried waste and subsequent transport by ground water is a difficult process to quantify. On the Hanford Site, the distance between the bottom of a site containing radioactive material and the top of the ground water varies from a few meters to over $70 \mathrm{~m}$. Sites in the Hanford 200 Areas are typically around $60 \mathrm{~m}$ above the groundwater, but sites in the 100 Areas can be as close as one or two meters. Calculation of rates of dissolution of radioactive material and transport through the vadose zone is complicated by the longer distances in the 200 Areas; therefore, representative calculations in the 100 Areas are given in the following sections. This results in a degree of conservatism from neglecting the additional dispersion and holdup that could be provided by the vadose zone.

\subsubsection{Migration Under Existing Conditions}

The average annual flow rate of the unconfined aquifer into the section of the Columbia River between river miles 360 and 356, several miles south of 100-F Area, has been estimated to be about $3 \mathrm{ft} 3 / \mathrm{s}\left(0.085 \mathrm{~m}^{3} / \mathrm{s}\right.$ ) (Prater et al. 1983) as determined by the Variable Thickness Transient (VTT) groundwater flow model developed for the Hanford Site (Reisenauer 1979). Over one-half of this flow occurs between river miles 359 and 360 . If an average value derived from this observation of about $400 \mathrm{~m} 3 / \mathrm{yr}$ per meter of shoreline is used as a representative value for current concitions, an approximation of the flow under a representative 100-Area 1-ha site may be taken to be about 
$4 \times 10^{4} \mathrm{~m}^{3} / \mathrm{yr}$. Travel times of this water from sites near the river into the river depend on the specific location of the waste site and the actual direction of the average ground-water flow. It is, however, a relatively quick transit, and a representative value of about 30 days is reasonably derived from the literature.

Radionuclides in the soil will not move to the ground water in appreciable quantities without a driving force provided by percolating water. Estimates of ground-water recharge (i.e., the amount of water trickling through the upper soil to the water table) for the Pasco Basin and the Hanford Site under present conditions vary with location and soil characteristics. The recharge is small but has been measured in the Hanford 300 Area to be around $5 \mathrm{~cm}$ of water per year in a wet year (Kirkham and Gee 1983). This could be sufficient to leach a small amount of material to the ground water every year. A leach rate of $0.01 \mathrm{yr}^{-1}$ is assumed here for most materials, and $0.001 \mathrm{yr}^{-1}$, for activated metals (Staley, Turi and Schreiber 1979). This assumed Teach rate is consistent with the Availability Correction Factor discussed earlier.

For an inventory $I(p C i)$ in a site, the annual average water concentration can be estimated from the following equation (Codell 1983).

$$
\bar{W}(t)=\frac{I \lambda_{L} e^{-\lambda_{R} t}}{F\left(\lambda_{L}+2 \lambda_{R}\right) T} \quad 1-e^{-\left(\lambda_{L}+2 \lambda_{R}\right) t}
$$

where $\bar{W}(t)=$ the average water concentration, $p C i / L$, at time $t$,

$I=$ the initial inventory, $\mathrm{pCi}$,

$\lambda_{L}=$ the leach rate constant, $y^{-1}$.

$\lambda_{R}=$ the radiological decay constant, $\mathrm{yr}^{-1}$,

$F=$ the dilution flow, L/yr, and

$T=$ an averaging time of $1 \mathrm{yr}$.

Equation 3.1 does not include any correction for retardation; that is, materials are assumed to move with water.

For an idealized waste site of area 1-ha, depth 1-m, and normalized concentration of $1 \mathrm{pCi} / \mathrm{g}$, this equation implies a maximum ground-water 
concentration of $5 \mathrm{pCi} / \mathrm{L}$ for loosely distributed material and of $0.5 \mathrm{pCi} / \mathrm{L}$ for activated metals. This concentration is assumed to result immediately downgradient of the waste site.

\subsubsection{Migration Enhanced by Irrigation}

Before the establishment of the Hanford Site, the area within about $3 \mathrm{~km}$ of the river from about the $100-K$ Area to several miles south of $100-F$ Area was under irrigation. It is reasonable to assume that, upon unrestricted release of the 100 Areas, a similar situation could recur. Because the supply of ground water is insufficient to support major irrigation through wells, it is assumed that the irrigation water is withdrawn from the columbia River.

Irrigation methods have improved with time to increase the efficiency of water application so that losses to the ground water are minimized. However, some excess irrigation is required to avoid accumulation of salts in the soil. Therefore, a nominal loss of $20 \%$ of applied water is assumed. For irrigation practices in the Columbia Basin, this could be up to $30 \mathrm{~cm} / \mathrm{yr}$ of recharge. This quantity of recharge throughout the $3-\mathrm{km}$ band along the river would act to raise the ground water, increasing the flow to the river and decreasing the travel time. This irrigation could increase the flow beneath a hypothetical waste site to about $1 \times 105 \mathrm{~m}^{3} / \mathrm{yr}$.

The increased flux of water through the buried waste would increase the leaching of radionuclides to the water table. A leach rate of $0.1 \mathrm{yr}^{-1}$ is assumed for most materials under these circumstances, and a leach rate of $0.01 \mathrm{yr}^{-1}$ is assumed for activated components (Staley, Turi and Schreiber 1979).

Equation 3.1, applied to the hypothetical 1 -ha waste site with $1 \mathrm{pCi} / \mathrm{g}$, results in a maximum projected ground-water concentration of $20 \mathrm{pCi} / \mathrm{L}$ for most radionuclides. For activated materials, the projected ground-water concentration is $2 \mathrm{pCi} / \mathrm{L}$. Retardation is neglected in these estimates. However, the travel time to the river is so short that retardation should be inconsequential.

For this scenario, an individual is assumed to draw drinking water from the unconfined aquifer through a well. He is assumed to drink $2 \mathrm{~L} / \mathrm{d}$ from 
this source. Because of the source of the irrigation water in this scenario, the enhanced migration of contaminants could impact people using the water for the Columbia River down stream (considered in Section 3.2).

\subsubsection{Ground-Water Migration Retarded by a Barrier}

Because of the potential for downward migration of buried materials to the water table, it is possible that barriers to water infiltration will be proposed and constructed. While these could conceivably eliminate recharge as a pathway, molecular diffusion would still remain as a minor source of contaminant movement to ground water.

Neglecting lateral diffusion or edge effects around the barrier (i.e., assuming one-dimensional transport downward), contaminant transport via diffusion can be described by the equation

$$
\mathrm{J}=-\mathrm{BDA} \frac{\partial \mathrm{C}}{\partial \mathrm{X}}
$$

$$
\text { where } \begin{aligned}
\mathrm{J} & =\text { activity flux, } \mathrm{Ci} / \mathrm{yr}, \\
\boldsymbol{\theta} & =\text { moisture content of the soil (dimensionless), } \\
\mathrm{D} & =\text { modified molecular diffusion constant, } \mathrm{m}^{2} / \mathrm{yr}, \\
\mathrm{A} & =\text { site area, } \mathrm{m}^{2}, \\
\mathrm{C} & =\text { activity concentration, } \mathrm{Ci} / \mathrm{m}^{3}, \text { and } \\
\mathrm{X} & =\text { longitudinal coordinate, } \mathrm{m} .
\end{aligned}
$$

This equation has boundary conditions of $C=C_{0}$ at the origin, assuming that the concentration at the waste/soil boundary is in equilibrium, and $\mathrm{C}=0$ at the water table, assuming that the flow in the ground water dilutes and removes the contamination.

One can visualize the release to the water table via the diffusion mechanism as occurring in three time phases: 1) zero release as the waste moves to the water table, 2) a period of constant release, and 3) a period of exponentially decreasing release as the source is depleted. For the maximum (second) period, the flux can be approximated as

$$
J=-\theta D A C O / L
$$


where $L=a$ distance over which the diffusion occurs.

The distance from the buried material to the water table varies from site to site. For certain sites in the 100-F Area, the distance can be as little as $1 \mathrm{~m}$ (Dorian and Richards 1978). The diffusion constant in a sandy loam material, similar to Hanford soils, has been shown to be about $0.15 \mathrm{~cm}^{2} /$ day $\left(5.4 \times 10^{3} \mathrm{~m} 2 / \mathrm{yr}\right)$. The moisture content of Hanford soils runs about $7 \%$. Application of these parameters to the hypothetical waste site used in the previous examples results in a nominal water concentration of 0.2 $\mathrm{pCi} / \mathrm{L}$ per $\mathrm{pCi} / \mathrm{g}$.

For compatibility with the other scenarios, the impact of this concentration of each nuclide in the ground water is measured using a drinkingwater scenario in which the individual is assumed to consume $2 \mathrm{~L} / \mathrm{d}$ from a well immediately downgradient from the buried radioactive material.

\subsection{OFFSITE SCENARIO/PATHWAYS}

The release of radionuclides to the Columbia River via ground water, as described for several different circumstances in Section 3.1.2, has the potential for impacts on both individuals and population groups downstream. ooses to individuals are calculated for

- ingestion of foodstuffs contaminated by effluents deposited on the ground by irrigation with Columbia River water

- drinking sanitary water obtained from the Columbia River

- exposure to ground contaminated by irrigation with Columbia River water

- ingestion of fish taken from the Columbia River

- recreation along the Columbia - boating, swimming and shoreline activities.

While there are no regulatory limits for collective population doses, such an evaluation provides an indication of the overall impact. The dose to the population within $80-\mathrm{km}$ of the site represents the summed products of average dose and number of individuals involved for all possible pathways. The units are man-rem. 
In the case of releases to the Columbia River, only that portion of the full $80 \mathrm{~km}$ population using river water are potentially exposed. The river-related exposure pathways are drinking water, irrigated food stuff, fish consumption, and river recreation. Descriptions of river-related pathways are as follows (McCormack, Ramsde11, and Napier 1984):

- Orinking Water - The cities of Richland and Pasco obtain their municipal water from the Columbia River downstrean from Hanford. The City of Kennewick began drawing a portion of its municipal water from the river in late 1980 . During 1984, approximately $40 \%$ of Kennewick drinking water was drawn from the Columbia River. The total affected population was approximately 70,000 .

- Irrigated Foodstuff - Columbia River water is withdrawn for irrigation of home vegetable gardens in the Riverview district of Pasco in Franklin County. Approximately 2000 people are estimated to be affected.

- River Recreation - These activities include swimming, boating, and shoreline recreation. The population residing adjacent to the river within $80 \mathrm{~km}$ of Hanford is assumed to be affected by these pathways and is estimated to number 125,000 .

- Fish Consumption - Population doses due to consumption of fish obtained locally from the Columbia River are calculated based on an estimated total annual catch of $15,000 \mathrm{~kg} / \mathrm{yr}$ without reference to a specific population group.

\subsection{ADDITIONAL SCENARIO DOSE CONVERSION FACTORS}

By applying the exposure conditions defined in Section 3.1 for the radiation exposure scenarios, and using the dose models discussed in Section 2, dose conversion factors for detemining ARCL values are calculated. The ARCL dose conversion factors are shown in Table 3.1 for specific radiation exposure pathways for radionuclides of potential interest during decommissioning. The dose factors are in units of effective dose equivalent (EDE) rem/yr per $\mathrm{pCi} / \mathrm{g}$, except for the two offsite dose factors; individual doses 
are in rem per $\mathrm{Ci}$ released to the river, and population doses are in man-rem per $\mathrm{Ci}$ released.

The new factors shown on Table 3.1 are similar in nature to the exposure pathway dose conversion factors in Table 2.1. The residential/home garden factors shown in Table 3.1 are derived directly from Table 2.1, by summing the external, inhalation, and ingestion factors.

\subsection{SENSITIVITY STUDIES AND RESULTS}

The dose factors in Table 3.1 and Table 2.1 provide the basic information necessary for comparison of the relative magnitude of the dose that results from the selected scenarios. Because these comparisons vary by radionuclide, and because in some instances the units of the dose factors are not directly compatible, it is easier to make the comparison using a representative 100-Area site as an example. Because the dose factors were derived for a hypothetical 1-ha site with uniform contamination, it is most appropriate to use a site with similar characteristics.

\subsubsection{Example Site Description}

A total of 28 solid-waste disposal sites have been identified in the 100 Areas of the Hanford Site (Harmon and King 1975). All of these sites have been retired since the early or mid-1970s, and all wastes generated since that time have been sent to the 200-Area waste sites for disposal. Solid waste burial grounds in the 100 Areas simply consist of unlined trenches that are filled with solid, radioactive wastes and covered with a meter or more of soil.

A hypothetical radionuclide inventory for the solid-waste burial grounds in the 100 Areas is given in Table 3.2. The radionuclides and relative concentrations shown in this table were nomalized to $1 \mathrm{pCi} / \mathrm{g}$.

\subsubsection{Scenario Result Comparison}

Results of application of the dose factors for the onsite (intruder) scenarios are presented in Table 3.3 for a hypothetical 1-ha burial ground containing $\mathrm{I} \mathrm{pCi} / \mathrm{g}$ of the waste spectrum of Table 3.2. Results are presented for the residential/home-garden scenario and agriculture scenario presented in Section 2. Contrasted to these scenarios are two scenarios of biotic 
TABLE 3.1. Additional Scenario Dose Conversion Factors in Units of Effective Dose Equivalent

\begin{tabular}{|c|c|c|c|c|c|c|c|c|}
\hline \multirow[b]{2}{*}{$\begin{array}{r}\text { Rad io- } \\
\text { nuel ide }\end{array}$} & \multicolumn{6}{|c|}{ Onsite Scenarios (rot/yr/por $\mathrm{pCi} / \mathrm{g}$ ) } & \multicolumn{2}{|c|}{ Domriver 5cenarios } \\
\hline & $\begin{array}{l}\text { Rosidential } \\
\text { Homo Gordon }\end{array}$ & $\begin{array}{c}\text { Biotic } \\
\text { Transport } \\
\text { at } 1 . \\
\end{array}$ & $\begin{array}{c}\text { Biotic } \\
\text { Transport } \\
\text { at } 5\end{array}$ & $\begin{array}{c}\text { Eristing } \\
\text { Conditions } \\
\end{array}$ & $\begin{array}{l}\text { Ground } \\
\text { Iator } \\
\text { Irriga- } \\
\text { tion } \\
\end{array}$ & $\begin{array}{l}\text { Ground } \\
\text { ynter } \\
\text { Barrior } \\
\text { Installed } \\
\end{array}$ & $\begin{array}{l}\text { Indi- } \\
\text { yidual } \\
\text { (rou/ci) }\end{array}$ & $\begin{array}{c}\text { Population } \\
\left(\operatorname{man}-\mathrm{ren}_{\mathrm{C}} \mathrm{Ci}\right)\end{array}$ \\
\hline $3 \mathrm{H}$ & $4.7 \mathrm{E}-6$ & --- (a) & $\cdots$ & 2.1E-7 & 8. $6 E-7$ & B. $6 \mathrm{E}-9$ & 9. $6 \mathrm{E}-16$ & $1.7 \mathrm{E}-\mathrm{5}$ \\
\hline $14 C$ & $4.6 \mathrm{E}-6$ & --- & -- & 7. 3E-8 & 2. 9E-5 & $2.9 \mathrm{E}-7$ & $3.7 \mathrm{E}-\mathrm{B}$ & $2.1 \mathrm{E}-3$ \\
\hline $36 \mathrm{Cl}$ & 2.3E-3 & $1.4 \mathrm{E}-3$ & $2,4 E-5$ & $1.1 \mathrm{E}-5$ & $4.2 \mathrm{E}-6$ & 4. $2 \mathrm{E}-7$ & 6. $4 E-7$ & $1.6 \mathrm{E}-3$ \\
\hline $57 \mathrm{Co}$ & 2. $6 \mathrm{E}-4$ & $2.7 \mathrm{E}-22$ & $3.1 \mathrm{E}-24$ & $5.5 E-8$ & 2. $2 \mathrm{E}-7$ & $2.2 \mathrm{E}-8$ & 3. $2 E-8$ & $6.4 \mathrm{E}-5$ \\
\hline${ }^{80 \mathrm{CO}}$ & 6. $4 \mathrm{E}-3$ & $8.7 E-7$ & $1.1 \mathrm{E}-\mathrm{a}$ & $7.3 \mathrm{E}-7$ & 2.9E-8 & $2.9 E-7$ & $7.3 \mathrm{E}-7$ & $1.1 \mathrm{E}-3$ \\
\hline $55 \mathrm{Fe}_{0}$ & $1.3 E-7$ & $9.8 \mathrm{E}-13$ & $1.4 \mathrm{E}-14$ & $4,3 \mathrm{E}-8$ & $1.7 \mathrm{E}-7$ & $1.7 \mathrm{E}-8$ & $3.5 E-8$ & $5.9 \mathrm{E}-5$ \\
\hline $59 \mathrm{Fo}_{0}$ & $2.9 \mathrm{E}-3$ & 6.6E & $6.6 E$ & $4.8 \mathrm{E}-7$ & $1.9 E-6$ & 1. 9E-7 & 3. $6 \mathrm{E}-7$ & $5.6 E-4$ \\
\hline $59 \mathrm{Ni}$ & $6.8 E-7$ & 4. $2 \mathrm{E}-7$ & $8.1 E-9$ & $1.4 \mathrm{E}-8$ & $5,4 E-8$ & $5.4 E-9$ & $1.1 \mathrm{E}-8$ & $1.7 \mathrm{E}-6$ \\
\hline${ }^{83} \mathrm{Ni}$ & 1. $5 \mathrm{E}-6$ & $8.8 E-7$ & $1.2 \mathrm{E}-8$ & 3. $8 \mathrm{E}-8$ & 1. $5 \mathrm{E}-7$ & $1.5 \mathrm{E}-8$ & $2.9 \mathrm{E}-8$ & $4.7 \mathrm{E}-5$ \\
\hline $96 \mathrm{Sr}$ & 4.1E-3 & $1.1 \mathrm{E}-3$ & $1.7 \mathrm{E}-6$ & $8.8 \mathrm{E}-5$ & $3.5 E-4$ & $3.5 \mathrm{E}-6$ & $3.8 E-8$ & $8.8 \mathrm{E}-3$ \\
\hline 9310 & 2. 9E-5 & $2.8 E-5$ & $3.0 E-7$ & 4. 5E-7 & $1.8 E-8$ & $1.8 E-8$ & $5.1 \mathrm{E}-8$ & 4.8E-4 \\
\hline $94 \mathrm{Nb}$ & $3.9 \mathrm{E}-3$ & $1.2 \mathrm{E}-4$ & $1.3 \mathrm{E}-6$ & $1.8 \mathrm{E}-\delta$ & 7. 2E-5 & $7.2 E-7$ & B. DE-5 & 3. $2 \mathrm{E}-2$ \\
\hline $99 \mathrm{Tc}$ & 5.1E-4 & $3.6 \mathrm{E}-4$ & $5.2 \mathrm{E}-8$ & $7,8 E-6$ & $3.1 \mathrm{E}-5$ & $3.1 \mathrm{E}-7$ & 2. 1E-7 & $8.8 E-4$ \\
\hline $124 \mathrm{Sb}$ & 5. $2 \mathrm{E}-3$ & $0.0 \mathrm{Eg}$ & 8.6E8 & 3. & 1. $2 \mathrm{E}-4$ & $1.2 \mathrm{E}-6$ & $2.4 \mathrm{E}-7$ & $2.4 E-3$ \\
\hline $125 \mathrm{Sb}$ & $1,2 \mathrm{E}-3$ & $5.8 \mathrm{E}-9$ & 8.1E-11 & 8. $3 E-6$ & $3.3 E-5$ & 3. 3E-7 & $1.7 \mathrm{E}-7$ & $7.8 \mathrm{E}-4$ \\
\hline $134 \mathrm{Cs}$ & $4.4 E-3$ & 1. $8 \mathrm{E}-10$ & $1.8 \mathrm{E}-12$ & $2.2 E-4$ & $8.8 E-4$ & $8.8 E-6$ & $5.4 \mathrm{E}-5$ & $4.9 \mathrm{E}-2$ \\
\hline $135 c_{s}$ & $2.1 E-8$ & $1.5 E-6$ & $2.2 E-8$ & $2.1 \mathrm{E}-5$ & $8.4 \mathrm{E}-5$ & $8.4 E-7$ & $5.1 \mathrm{E}-6$ & $3.8 \mathrm{E}-3$ \\
\hline $137 \mathrm{Cs}_{\mathrm{s}}$ & $1.5 E-3$ & $2.0 \mathrm{E}-5$ & $2.3 E-7$ & $1.5 E-4$ & 6. $8 \mathrm{E}-4$ & $6.9 \mathrm{E}-6$ & $3.7 \mathrm{E}-5$ & $2.7 \mathrm{E}-2$ \\
\hline $144 \mathrm{Co}$ & $1.4 \mathrm{E}-4$ & $1.1 \mathrm{E}-21$ & 1. $8 \mathrm{E}-23$ & 1. $5 \mathrm{E}-4$ & B. $1 \mathrm{E}-5$ & 6.1E-7 & $2.4 E-7$ & $1.4 \mathrm{E}-3$ \\
\hline 152Eu & $3.9 \mathrm{E}-3$ & 9.9E-6 & $1.2 \mathrm{E}-7$ & $4.5 \mathrm{E}-6$ & $1.8 \mathrm{E}-5$ & $1.8 E-7$ & 3. $5 \mathrm{E}-7$ & 6. $4 \mathrm{E}-4$ \\
\hline 154EU & $3.1 \mathrm{E}-3$ & 3. 3E-6 & $3.8 \mathrm{E}-8$ & $6.8 \mathrm{E}-6$ & $2.7 \mathrm{E}-5$ & $2.7 \mathrm{E}-7$ & 4.2E-7 & 8. $6 E-4$ \\
\hline 226Ra & 6.9E-2 & $4,6 \mathrm{E}-2$ & $6.7 E-4$ & $2,4 E-3$ & $9.5 \mathrm{E}-3$ & $9.5 \mathrm{E}-5$ & $3.3 \mathrm{E}-5$ & 2.1E-1 \\
\hline $232 \pi \mathrm{h}$ & $9.8 E-3$ & $1.8 \mathrm{E}-3$ & 2. $2 \mathrm{E}-5$ & $7,8 \mathrm{E}-3$ & $2.8 \mathrm{E}-2$ & $2.8 \mathrm{E}-4$ & B. $8 \mathrm{E}-\mathrm{-5}$ & 8. $9 E-1$ \\
\hline 2350 & $2.7 \mathrm{E}-4$ & $1.3 E-5$ & $1.7 \mathrm{E}-7$ & 6. GE-5 & $2.8 \mathrm{E}-4$ & $2.8 \mathrm{E}-6$ & $2.6 E-7$ & $5.7 E-3$ \\
\hline 2380 & 1. $0 \mathrm{E}-4$ & $1.5 \mathrm{E}-5$ & 2.1E-7 & 6. $6 \mathrm{E}-5$ & $2.4 E-4$ & $2.4 E-8$ & $5.7 E-7$ & 5. 3E-3 \\
\hline $237_{\mathrm{Np}}$ & $3.6 \mathrm{E}-3$ & $1.5 \mathrm{E}-3$ & 2. $2 \mathrm{E}-5$ & $1.3 \mathrm{E}-2$ & 8. $2 E-2$ & 5. $2 E-4$ & $1.1 \mathrm{E}-4$ & $1.1 \mathrm{E}+\mathrm{B}$ \\
\hline 238Pu & $1.3 \mathrm{E}-4$ & $9.4 E-8$ & 1.3E-7 & 8. 5E-4 & 3. $4 E-3$ & $3,4 E-5$ & $8.4 E-6$ & 7. $2 \mathrm{E}-2$ \\
\hline 239Pu & 1. $5 E-4$ & $1.4 \mathrm{E}-5$ & 1. 9E-7 & 9. 3E-4 & $3.7 \mathrm{E}-3$ & $3.7 \mathrm{E}-5$ & 7. $6 \mathrm{E}-6$ & 7.9E-2 \\
\hline 241 A & 3. $5 E-4$ & $1.4 \mathrm{E}-5$ & 1. $5 \mathrm{E}-8$ & $9.6 \mathrm{E}-3$ & 3. $8 E-2$ & $3.8 E-4$ & 9.7E-5 & $7.8 \mathrm{E}-1$ \\
\hline
\end{tabular}

transport and three scenarios of ground-water transport. The biotic transport scenarios correspond to the standard intrusion scenarios of minimal overburden $(<1 \mathrm{~m})$ and greater than $5 \mathrm{~m}$ of overburden. For unconfined soil, the biotic transport model gives results identical to those for the agricultural scenario with resuspension and external, so they are not repeated. Barriers are assumed to be able to preclude biotic transport. The depth of 
IABLE 3.2. Representative Radionuclide Inventory for the Example Site

\begin{tabular}{|c|c|c|c|}
\hline Radionuclide & $\begin{array}{c}\text { Relative Activity } \\
\text { at } \mathrm{T}=0 \text { yr } \\
(\mathrm{pC} \mathrm{i} / \mathrm{g})\end{array}$ & $\begin{array}{c}\text { Relative Activity } \\
\text { Decayed to } \\
\mathrm{T}=100 \mathrm{yr} \\
(\mathrm{pCi} / \mathrm{g}) \\
\end{array}$ & $\begin{array}{c}\text { Relative Activity } \\
\text { Decayed to } \\
\mathrm{T}=300 \mathrm{yr} \\
(\mathrm{pCi} / \mathrm{g})\end{array}$ \\
\hline${ }^{60} \mathrm{Co}$ & $9.1 E-1^{(a)}$ & $1.8 \mathrm{E}-6$ & $6.7 \mathrm{E}-18$ \\
\hline${ }^{63} \mathrm{Ni}$ & $8.7 E-3$ & $4.4 E-3$ & $1.0 \mathrm{E}-3$ \\
\hline${ }^{90}{ }_{S r+D}(b)$ & $1.6 \mathrm{E}-2$ & $1.3 E-3$ & $8.3 E-6$ \\
\hline${ }^{137} \mathrm{Cs}+\mathrm{D}$ & $1.3 E-2$ & $1.3 \mathrm{E}-3$ & $1.3 \mathrm{E}-5$ \\
\hline${ }^{152} \mathrm{Eu}$ & $9.2 \mathrm{E}-2$ & $5.5 E-4$ & $6.7 E-9$ \\
\hline${ }^{154} \mathrm{Eu}$ & $4.2 \mathrm{E}-2$ & $1.4 \mathrm{E}-5$ & $1.4 \mathrm{E}-12$ \\
\hline${ }^{23} 8_{U+D}$ & $1.8 \mathrm{E}-5$ & $1.8 E-5$ & $1.8 \mathrm{E}-5$ \\
\hline${ }^{239} \mathrm{Pu}$ & $1.1 \mathrm{E}-4$ & $1.1 \mathrm{E}-4$ & $1.1 \mathrm{E}-4$ \\
\hline TOTALS & 1.0 & 0.0077 & 0.0012 \\
\hline
\end{tabular}

(a) Where $9.1 \mathrm{E}-1=9.1 \times 10^{-1}$.

(b) $+D$ means plus short-lived daughter products.

TABLE 3.3. Relative Dose Rates for the Various Onsite Scenarios for the Example Site Inventory, Effective Dose Equivalent, at $T=0 \mathrm{yr}$

\begin{tabular}{|c|c|c|c|c|c|c|c|}
\hline \multirow{2}{*}{$\begin{array}{l}\text { Radio- } \\
\text { nuelidg }\end{array}$} & \multicolumn{2}{|l|}{ Residential/ } & Giotic & insport & \multicolumn{3}{|c|}{ Ground-Water Wigration } \\
\hline & Hone Gardon & Agriculture & $\begin{aligned} \text { Byote } \\
-4 \text { Soil }\end{aligned}$ & $\frac{\ln 30 \text { port }}{25-50 i}$ & $\begin{array}{l}\text { Existing } \\
\text { Exts }\end{array}$ & Irrigation & $\frac{\text { Con }}{\text { Barrier }}$ \\
\hline & 5. $8 \mathrm{E}-3$ & $1.4 \mathrm{E}-5$ & $7.9 \mathrm{E}-7$ & 1. $0 \mathrm{E}-\mathrm{B}$ & $8.8 E-7$ & $2.6 \mathrm{E}-6$ & $2.6 \mathrm{E}-7$ \\
\hline & 1. $3 \mathrm{E}-8$ & $1,3 E-8$ & $7.5 E-8$ & 1. $0 E-10$ & 3. $3 \mathrm{E}-1 \mathrm{Z}$ & $1.3 \mathrm{E}-9$ & 1. 3E-10 \\
\hline${ }^{90} \mathrm{Sr}$ & $6.6 \mathrm{E}-5$ & B. 6E-5 & $1.8 E-5$ & $2.7 \mathrm{E}-8$ & $1.4 \mathrm{E}-8$ & $5.8 E-8$ & $5.8 E-8$ \\
\hline & 2. $0 \mathrm{E}-5$ & 2. $0 \mathrm{E}-7$ & $2.6 \mathrm{E}-7$ & 3. $0 \mathrm{E}-9$ & 2. $0 E-8$ & 7. $\mathrm{aE}-8$ & 7. $8 \mathrm{E}-8$ \\
\hline${ }^{152}{ }_{E I}$ & $2.8 E-4$ & $2.45-7$ & $9.1 \mathrm{E}-7$ & $1.1 E-8$ & $4.1 E-7$ & $1.7 \mathrm{E}-8$ & $1.7 \mathrm{E}-8$ \\
\hline${ }^{154} \mathrm{Eu}$ & 1. $3 \mathrm{E}-4$ & $1.6 \mathrm{E}-7$ & $1.4 E-7$ & $1.6 \mathrm{E}-9$ & $2.9 \mathrm{E}-7$ & $1.1 E-6$ & $1.1 E-8$ \\
\hline${ }^{238} \mathrm{U}$ & $1.8 E-9$ & 3. $2 \mathrm{E}-12$ & 2.7E-10 & 3. $8 E-12$ & $1.1 \mathrm{E}-9$ & $4.3 \mathrm{E}-9$ & $4.3 E-10$ \\
\hline${ }^{239} \mathrm{Pu}$ & $\underline{1.7 \mathrm{E}-8}$ & $1.8 \mathrm{E}-9$ & $1.5 \mathrm{E}-9$ & 2.1E-11 & $\underline{1.0 E-7}$ & $4.1 E-7$ & 4.1E-9 \\
\hline TOTNL & $6.2 E-3$ & 8.0E-5 & 2. $D E-5$ & 6. $3 \mathrm{E}-8$ & 4. $9 \mathrm{E}-8$ & 1.9E-5 & \\
\hline
\end{tabular}


cover is of less significance for the ground-water transport scenarios, but the nature of the cover and the activities on the cover are of concern. Thus, the calculations are provided for wastes under presently existing conditions, under assumed irrigation, and under a barrier designed to prevent water infiltration.

Table 3.4 presents results of similar calculations of potential doses to individuals and populations downstream along the Columbia River resulting from the $100 \%$ release of the hypothetical waste site inventory to the river via ground-water transport. Doses to the individual are presented in the same units Table 3.3, those to the population are in terms of total man-rem to total body.

Inspection of Tables 3.3 and 3.4 reveals that the standard scenarios employed in Kennedy and Napier (1983b), for intruders into the wastes, yield the highest projected individual annual doses. The doses to individuals offsite, shown in Table 3.4, are lower than from any of the onsite doses. Of the onsite doses, only the scenarios of biotic transport with minimal cover (very close to the agricultural scenario) and of heavy irrigation with attendant nuclide migration into drinking water approach the standard scenarios in magnitude. Thus, it is apparent that the initial selection of humanintrusion-based scenarios for ARCL determination is appropriately conservative. It also indicates that compounding of scenarios, e.g., adding together irrigation with the intruder, would result in negligible dose increases over the intruder alone.

\subsubsection{Discussion of Results}

The scenarios initially chosen for use in the ARCL calculations are shown to be reasonable and conservative. Offsite doses are very low in comparison to potential onsite exposures and can be considered to be negligible. (The offsite population dose in total man-rem is less than the potential dose to a single onsite individual, in rem.) of the onsite scenarios, only biotic transport with minimal cover and the drinking-water scenario driven by high irrigation recharge approach the magnitude of the intrusion-based scenarios. Biotic transport does not appear to be a significant pathway for migration beyond that component already assumed in the agricultural scenarios. 
TABLE 3.4. Relative Effective Dose Equivalent Rates for the Various Offsite Scenarios for the Example Site Inventory at $T=0 \mathrm{yr}$

\begin{tabular}{|c|c|c|}
\hline Radionuclide & $\begin{array}{l}\text { Maximum Downriver Individual } \\
\text { (rem per } \mathrm{pCi} / \mathrm{g} \text { ) } \\
\end{array}$ & $\begin{array}{l}\text { Total Downriver Population } \\
\text { (man-rem per } \mathrm{pC}(\mathrm{g} / \mathrm{g}) \\
\end{array}$ \\
\hline${ }^{60} \mathrm{Co}$ & $1.0 \mathrm{E}-8$ & $1.5 \mathrm{E}-5$ \\
\hline${ }^{63} \mathrm{Ni}$ & $3.8 \mathrm{E}-12$ & $6.1 E-9$ \\
\hline${ }^{90} \mathrm{Sr}$ & $9.1 \mathrm{E}-10$ & $2.4 \mathrm{E}-6$ \\
\hline${ }^{137} \mathrm{Cs}$ & $7.2 \mathrm{E}-9$ & $5.3 E-6$ \\
\hline${ }^{152} \mathrm{Eu}$ & $4.8 \mathrm{E}-10$ & $8.8 \mathrm{E}-7$ \\
\hline${ }^{154} \mathrm{Eu}$ & $2.6 \mathrm{E}-10$ & $5.4 \mathrm{E}-7$ \\
\hline $238 \mathrm{U}$ & $1.5 E-13$ & $1.4 \mathrm{E}-9$ \\
\hline${ }^{239} \mathrm{Pu}$ & $1.2 \mathrm{E}-11$ & $1.3 \mathrm{E}-7$ \\
\hline TOTALS & $1.9 E-8$ & $2.4 \mathrm{E}-5$ \\
\hline
\end{tabular}

The biotic transport and ground-water migration scenarios are, to a large degree, dependent more on the total inventory of radionuclides buried than on the concentration of these materials in the soils. This tends to mask the potential impacts of nonuniformity in the disposed material. The intrusion scenarios, on the other hand, reflect the impact of such nonuniformities, because the intruders are commonly assumed to interact with the areas of higher concentration. This conservatism helps assure that the potential for doses to future individuals is not minimized. 


\subsection{A STATISTICAL APPROACH FOR MAKING REMEDIAL ACTION \\ DECISIONS BASED ON THE ARCL METHODOLOGY}

This section discusses the statistical application of the ARCL method for deciding whether or not a contaminated nuclear facility or site requires remedial action before it can be released for unrestricted public use. The formulas and discussion are meant to provide an overview of the statistical remedial action decision-making approach using ARCL methodology. Step-by-step descriptions and worksheets are provided in Section 5.0.

Remedial action (RA) decisions are made by comparing radionuclide measurements (or functions thereof) to regulatory or other guidelines. Usually it is not possible to characterize $100 \%$ of a site or facility, so samples are taken and radionuclide measurements are made on the samples. The RA decision is then based on this sample information. Unfortunately, a nonstatistical decision rule (one that ignores the variability among sample radionuclide measurements) is often used. If the variability among sample measurements is large, the result can be high probabilities of making wrong RA decisions (i.e., deciding $R A$ is required when it is not, or deciding $R A$ is not required when it is).

When a statistical approach to making RA decisions is used, the variability among measurements is taken into account, and the probabilities of making incorrect decisions can be assessed. Further, these probabilities can be controlled at user-specified values by taking a sufficient number of samples.

\subsection{STATISTICAL REMEDIAL ACTION DECISIONS}

The remedial action decision-making process for decommissioning operations at Hanford is based on the requirement that the annual radiation dose to a maximally exposed individual (subsequently denoted by $D$ ) must be below $25 \mathrm{mrem} / \mathrm{yr}$. The ARCL methodology provides the means for estimating $D$, given information about radionuclide concentrations and inventories. Specifically, radionuclide inventories or mean concentrations are multiplied by radionuclide dose factors to yield radionuclide doses, which are then sumed over radionuclides, strata, and scenario/exposure-pathways to yield an estimate $\hat{D}$ of $D$. 
In practice, radionuclide concentration (or inventory) information is obtained by collecting physical samples from contaminated facilities and making radionuclide measurements on the samples. Because levels of contamination in the samples are often quite variable, the estimate of $D$ can be quite variable. (a) This variability must be taken into account in specifying the RA decision rule.

The statistical approach to making an ARCL remedial action decision uses a hypothesis-testing framework and involves computing a one-sided $100(1-\alpha) \%$ confidence limit on $D$. If the confidence Timit exceeds the dose limit (25 $\mathrm{mrem} / \mathrm{yr}$ ), then RA is required. It is possible to use either an upper or lower confidence limit in this procedure. The choice between the lower and upper confidence limits depends on which of the two potential decision errors is more important to control. If the consequences of deciding "RA is not required when it is actually needed" are more severe than the consequences of deciding "RA is required when it is not actually needed," then the upperconfidence-limit decision rule should be used. If the opposite is the case, the lower confidence limit should be used. Through discussions with decommissioning personnel, it was concluded that the more serious decision error is deciding that "RA is not required when it is actually needed," which leads to using the upper confidence limit.

The following sections describe how to compute the upper confidence limit on $D$.

\subsection{THE $100(1-a) \%$ UPPER CONFIDENCE LIMIT DECISION RULE}

This section shows how to compute an approximate 100(1- $\alpha) \%$ upper confidence limit (UCL) on the true unknown annual dose $D$ to a maximally exposed individual where the desired confidence, $1-\alpha$, is specified by the user. This computed UCL is compared to the $25 \mathrm{mrem} / \mathrm{yr}$ limit to decide whether RA is needed. (a) Note that onty the sampling variability in estimating inventories is factored into the UCL. The dose factors are treated as if they were known

(a) It is possible to reduce this variability through the use of stratification in sampling contaminated facilities. Stratification is discussed in more deta 11 in Sections $4.2,4.3$, and 5.1. 
without error (this is obviously not the case, but it is beyond the scope of work to consider uncertainties in radionuclide dose factors).

\subsubsection{Main Formulas for UCL}

The method used to estimate $D$ (discussed in Sections 4.3 and 5 ) suggests that the estimate $\hat{D}$ ought to be approximately normaliy distributed. Under this assumption, an approximate $100(1-\alpha) \%$ upper confidence limit on $D$ is given by

$$
U C L=\hat{D}+z_{1-\alpha} S D(\hat{D}),
$$

where $\hat{D}=$ the estimated annual dose to a maximally exposed individual for the facility or group of facilities being studied,

$S D(\hat{D})=$ the computed standard deviation of $\hat{D}$, (a measure of the uncertainty in $\hat{D})$, and

$z_{1-\alpha}=$ the value from the standard nomal distribution ${ }^{(b)}$ such that $(1-\alpha) 100 \%$ of the distribution lies to the left of the value.

The estimate $\hat{D}$ of $D$ is obtained in stages. The ARCL methodology allows a maximalty exposed individual to receive dose contributions from more than one scenario. We denote by $\hat{D}_{s}$ the estimated dose from scenario $s$, and by $\operatorname{SD}\left(\hat{D}_{s}\right)$ the computed standard deviation of $\hat{D}_{s}$. We assume that the $\hat{D}_{s}$ variables (and levels of contamination within the scenarios) are statistically independent. (a)

Then

$$
\hat{D}=\sum_{s=1}^{S} \hat{D}_{s}
$$

and

(a) The UCL may be computed for the current value of dose, for the $100-y r$ decayed dose, etc. Also, the UCL formulas are not dependent on the 25 mrem/yr Timit. Any Timit may be used for comparison.

(b) The standard normal distribution has mean zero and variance 1. 


$$
\operatorname{SD}(\hat{D})=\sum_{s=1}^{S}\left\{\left[\operatorname{SD}\left(\hat{D}_{s}\right)\right]^{2}\right\}^{\frac{1}{2}}
$$

Methods for computing $\hat{D}_{S}$ and $S D\left(\hat{D}_{S}\right)$ for each scenario are given in Section 4.3. Once $\hat{D}_{s}$ and $S D\left(\hat{D}_{s}\right)$ values are computed for a given scenario, a $100(1-a) \%$ UCL may be computed for each $D_{s}$ using a formula analogous to Equation (4.1). This will indicate whether the dose for a single scenario is sufficient to decide that RA is required.

\subsubsection{Discussion}

The uncertainty in $\hat{D}$ [measured by $S D(\hat{D})]$ is assumed to be a result of sampling and measurement variability. The dose factors used in computing $\hat{D}$ are assumed to be known without error. This is certainly not the case, but it is beyond the scope of this report to consider the possible bias and uncertainty in the dose factor estimates.

The $100(1-\alpha) \%$ UCL in Equation (4.1) is computed using sample measurement data. Its interpretation is as follows: if the entire sampling, measurement, and UCL computation procedure were repeated many times on the same facility or site, the true value of $D$ would be less than the computed UCL approximately $100(1-\alpha) \%$ of the time. Of course, we will only sample and compute the UCL once for a given situation, with a $100 \alpha \%$ chance of the true value of $D$ being larger than the calculated UCL.

It is desirable for $\hat{D}$ to be an accurate estimate of $D$, and for $S D(\hat{D})$ to be small. Because the dose factors are assumed to be known without error, the number of physical samples and how they are selected determines $\hat{D}$ and $\operatorname{SD}(\hat{D})$. For example, it is quite natural to take more samples in more highly contaminated areas than in less-contaminated areas. However, untess done in the correct manner, $\hat{D}$ can be biased high and $S D(\hat{D})$ can be much too large (which could falsely indicate the need for RA).

(a) Although this is not an entirely valid assumption for some situations, it should not significantly affect the results. 
The solutions to these potential problems involve the use of stratified random sampling and the collection of a sufficient number of physical samples from each stratum. Stratified random sampling consists of dividing a contaminated area into subareas called strata, and performing simple random sampling within each stratum. Strata are defined so that mean concentration levels between the strata are quite different, and concentration variability within each stratum is as small as possible. Stratification for ARCL remedial action decision-making is discussed in Section 5.1. (The choice of size is discussed in Section 5.1).

\subsection{COMPUTATION OF SCENARIO DOSE AND STANDARD DEVIATION ESTIMATES FOR STRATIFIED RANDOM SAMPLING}

In this section formulas are given for computing $\hat{D}_{S}$ and $S D\left(\hat{D}_{s}\right)$ using radionuclide concentration data obtained from stratified random sampling at a facility. These formulas are valid for a given scenario. If the annual dose to a maximally exposed individual results from contributions from more than one scenario, the $\hat{D}_{S}$ and $S D\left(\hat{D}_{S}\right)$ values for the contributing scenarios must be combined, as discussed in Section 4.2.

\subsubsection{Formulas and Notation}

The notation used in this section is defined below. The estimated contribution of scenario " $s$ " to the annual dose for a maximaliy exposed individual is given by

$$
\hat{D}_{s}=\sum_{h=1}^{H} \sum_{j=1}^{L} d_{h i} y_{h i}
$$

where

$$
\begin{gathered}
y_{h i}=m_{h} \bar{x}_{h i}, \\
\text { and } \bar{x}_{h i}=\frac{1}{n_{h i}} \sum_{\ell=I}^{n_{h i}} x_{h i \ell} .
\end{gathered}
$$


The standard deviation of $\hat{D}_{S}$ is given by

$$
\operatorname{SD}\left(\hat{D}_{s}\right)=\sum_{h=1}^{H}\left\{\left[\sum_{i=1}^{L} d_{h i}^{2} m_{h}^{2} \frac{\hat{\sigma}_{h i}^{2}}{n_{h i}}+2 m_{h}^{2}\left(\sum_{j<k}^{L} \sum_{h j} d_{h k} \frac{\hat{\sigma}_{h j k}}{n_{h j k}}\right)\right]\right\}^{\frac{1}{2}}
$$

The notation used in the above equations is defined below

$L=$ the total number of radionuclides present over all strata,

$H=$ the number of strata for the scenario being considered,

$d_{h i}=$ the dose factor ( $r e m / y r$ per $p C i$ ) corresponding to radionuclide $i$ in stratum $h$ for the scenario under consideration,

$y_{h i}=$ estimated inventory ( $p C i$ ) of radionuclide $i$ in the hth straturm for the scenario under consideration,

$\bar{x}_{h i}=$ estimated mean concentration $\left(\mathrm{pCi} / \mathrm{g}\right.$ or $\left.\mathrm{pCi} / \mathrm{m}^{2}\right)$ of radionuclide $i$ in the hth stratum,

$x_{\text {hil }}=$ measured concentration value $\left(\mathrm{pCi} / \mathrm{g}\right.$ or $\left.\mathrm{pCi} / \mathrm{m}^{2}\right)$ of radionuclide $i$ in the eth sample taken from stratum $h$,

$m_{h}=$ the mass (or area, if concentrations on an area basis) of contaminated material (grams) in stratum $h$,

$n_{h i}=$ the number of samples from stratum $h$ that were analyzed for radionuclide $i$,

$\hat{\sigma}_{h i}^{2}=$ the estimated variance of concentration values of radionuclide $i$ in stratum $h$. This is based on the $n_{h i}$ concentration values $x_{h i k}$ of radionuclide $i$ available from stratum $h$, and is calculated via the formula

$$
\hat{\sigma}_{h i}^{2}=\frac{1}{n_{h i}-1} \sum_{\ell=1}^{n_{h i}}\left(x_{h i \ell}-\bar{x}_{h i}\right)^{2},
$$




$$
\begin{aligned}
n_{h j k}= & \text { the number of samples from stratum } h \text { for which concentration values } \\
& \text { of both radionuclides } j \text { and } k \text { are available, and } \\
\hat{\sigma}_{h j k}= & \text { the estimated covariance of concentration values of radionuclides } j \\
& \text { and } k \text { in stratum } h \text {. This is based on the } n_{h j k} \text { concentration-value } \\
& \text { pairs ( } \left.x_{h j k k,} \text { xhk }\right) \text { available from stratum } h \text {, and is calculated via } \\
& \text { the formula } \\
& \hat{\sigma}_{h j k}=\frac{1}{n_{h j k}-1} \sum_{\ell=1}^{n_{h j k}}\left(x_{h j \ell}-\bar{x}_{h j}\right)\left(x_{h k \ell}-\bar{x}_{h k}\right) .
\end{aligned}
$$

$\hat{\sigma}_{h j k}=$ the estimated covariance of concentration values of radionuclides $j$ and $k$ in stratum $h$. This is based on the $n_{h j k}$ concentration-value pairs $\left(x_{h j \ell k}, x h k \ell\right)$ available from stratum $h$, and is calculated via

The formula (4.7) for $\operatorname{SD}\left(\hat{D}_{s}\right)$ is based on the assumption that the concentration level of a radionuclide in one stratum is independent of the levels of the radionuclide or other radionuclides in other strata. This assumption simplifies what would otherwise be a much more complicated formula that would require sophisticated techniques to estimate spatial correlations. It is believed that the between-strata correlations would not contribute significantly to the overall value of $S D\left(\hat{D}_{S}\right)$.

\subsubsection{Decay Considerations}

Equations (4.4) - (4.9) may be used to compute $\hat{D}_{s}$ and $\operatorname{SD}\left(\hat{D}_{s}\right)$ for current contamination levels or for future decayed levels of contamination. For Hanford, a decay period (institutional control period) of $t$ years is of interest. Formulas (4.4) - (4.9) can be used directly for decay situations if the decay factors $e^{-\lambda}{ }_{i}$ are applied to the raw radionuclide concentration values $x_{\text {hi } \ell}$ before performing any other calculations. However, it is also possible to compute $\hat{D}_{S}$ and $\operatorname{SD}\left(\hat{D}_{S}\right)$ for decay, given the current-value summary statistics $\mathrm{y}_{h i}, \hat{\sigma}_{h i}, \hat{\sigma}_{h i j}$. The modified versions of Equations (4.4) and (4.7) are

$$
\hat{D}_{s}(t)=\sum_{h=1}^{H} \sum_{i=1}^{L} d_{h i}\left(e^{-\lambda} t^{t}\right) y_{h i}
$$


and

$$
\begin{aligned}
& S D {\left[\hat{D}_{s}(t)\right]=\left\{\sum _ { h = 1 } ^ { H } \left[\sum_{i=1}^{L}\left(e^{-\lambda_{j} t}\right)^{2} d_{h i}^{2} m_{h}^{2} \frac{\hat{\sigma}_{h i}^{2}}{n_{h i}}\right.\right.} \\
&\left.\left.+2 m_{n}^{2} \sum_{j<k} d_{h j}^{L} d_{h k} e^{-\left(\lambda_{j}+\lambda_{k} ; t\right.} \frac{\hat{\sigma}_{h j k}}{n_{h j k}}\right]\right\}^{\frac{1}{2}}
\end{aligned}
$$

where $D_{5}(t)$ is the annual dose to a maximally exposed individual involved in the scenario considered $t$ years from now. The decay constants $\lambda_{j}$ are given for various radionuclides in Table 5.3 .

Once $\hat{D}_{s}(t)$ and $S D\left[\left(\hat{D}_{s}(t)\right]\right.$ are computed, they are then substituted into Equation (4.1) to yield the $100(1-\alpha) \%$ UCL for $D_{s}(t)$. Similarly, once values of $\hat{D}_{s}(t)$ and $S D\left[\left(\hat{D}_{s}(t)\right]\right.$ are computed for all scenarios contributing to the dose for a maximally exposed individual, they may be substituted into Equations (4.2) and (4.3). The results of Equations (4.2) and (4.3) are then substituted into $(4.1)$ to yield the $100(1-\alpha) \%$ UCL on $D(t)$. 


\subsection{PROCEDURES FOR APPLYING ARCL TO A CONTAMINATED FACILITY}

Application of the general method outlined in Section 2 to an actual facility can be a complicated undertaking. A multitude of interdependent calculations may be required for sites with multiple contaminated zones, various types of waste materials, and potential interactions with adjacent facilities. To permit uniform application of the concepts and scenarios presented in Section 2, a complete stepwise process is described in this section. The seven general activities required for this process are illustrated in Figure 5.1. Each of these activities is further described in Sections 5.1 through 5.7 of this section. Each of the seven basic activities is comprised of from one to five tasks. Each task, in turn, is composed of from one to eight procedures. A total of 25 separate procedures are detailed in a step-by-step manner. To aid in understanding the procedures, example worksheets of the ARCL evaluation of a Hanford facility are included in Appendix $A$. Because reference is made often to the nine worksheets in the text, Table 5.1 lists them and provides the figure numbers of the examples in this chapter. Copies of the worksheets are also provided in Appendix B.

Preparation of a comprehensive site radionuclide inventory is the necessary first activity. This activity includes sampling and monitoring procedures that are outside the scope of this manual, but mention is made of where these tasks fit into the entire process.

The radionuclide inventory is adjusted in the second activity for application to each of the three controlling exposure scenarios for each stratum of contaminated material. This adjustment can include corrections for radioactive decay if the proposed action is not immediate decontamination and release of the facility.

The calculation of individual radiation doses for each scenario and stratum proceeds concurrently for the three major exposure scenarios, as illustrated in Figure 5.1. The dose estimates from the residential/homegarden and agricultural scenarios are summed, and the sum compared to the resource recycle result. Then, for the more restrictive dose, the $100(1-\alpha) \%$ upper confidence limit is compared to the mandated dose limit to determine if the proposed decomnissioning alternative is acceptable. 


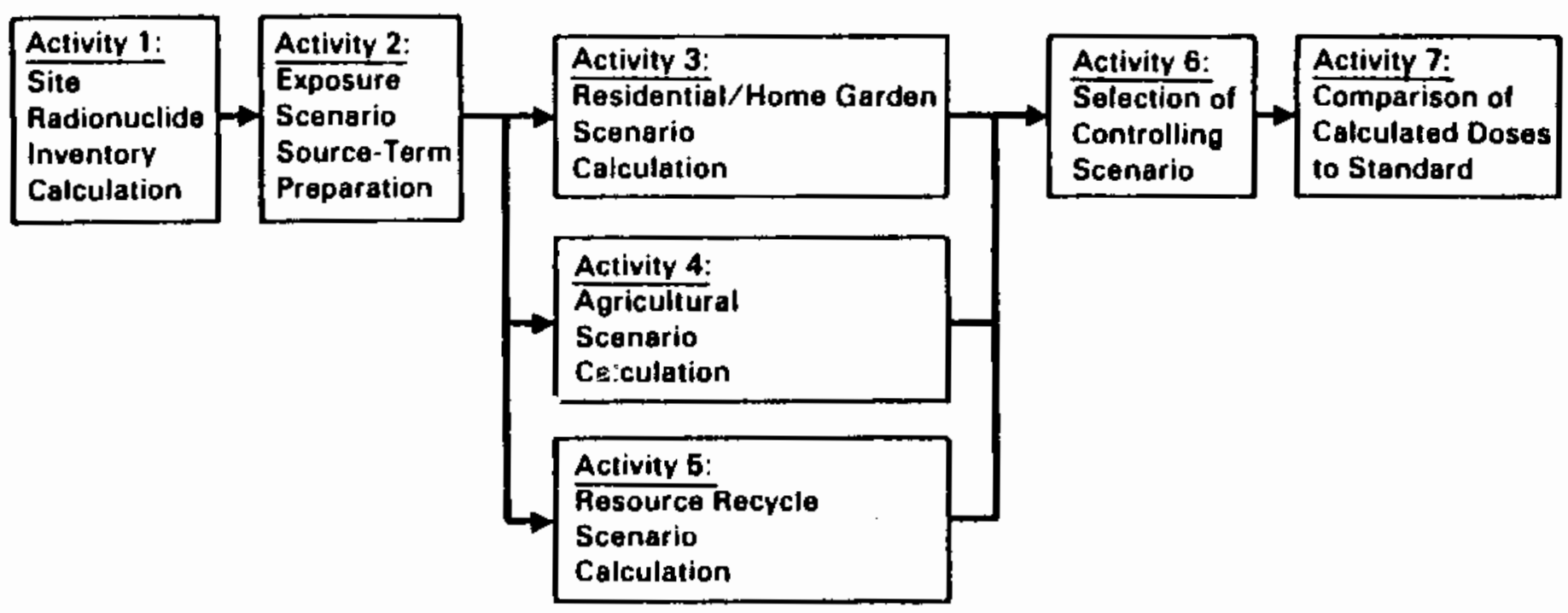

FIGURE 5.1. Required Activities During an ARCL Calculation 
IABLE 5.1. Worksheets Used for ARCL Analysis of Contaminated Facilities

\begin{tabular}{|c|c|c|}
\hline Form & Worksheet Title & $\begin{array}{l}\text { Figure Number } \\
\text { in Text }\end{array}$ \\
\hline A & $\begin{array}{l}\text { Summary Statistics Table--Estimated Means } \\
\text { Standard Deviations, and Covariances per Stratum }\end{array}$ & Figure 5.3 \\
\hline B & Source-Term Worksheet & Figure 5.5 \\
\hline$c$ & Availability Correction Worksheet & Figure 5.7 \\
\hline D & Stratum Dose Calculation Worksheet & Figure 5.8 \\
\hline E & Dose Variance Calculation Worksheet & Figure 5.9 \\
\hline$F$ & Area Correction Worksheet & Figure 5.11 \\
\hline G & Depth Correction Worksheet & Figure 5.12 \\
\hline H & Mass Correction Worksheet & Figure 5.14 \\
\hline I & Final ARCL Worksheet & Figure 5.16 \\
\hline
\end{tabular}

Careful completion of each of the seven activities will provide a completely documented selection of the final site disposal alternative.

\subsection{ACTIVITY 1 - SITE RADIONUCLIDE INVENTORY CALCULATION}

The five basic tasks required to fully define the radionuclide inventory of a particular site or facility are illustrated in Figure 5.2. Procedures for implementing these tasks are listed in Table 5.2. It should be noted that details of Tasks 1.2 through 1.4 are outside the scope of this manual. Although portions of 'Task 1.2 are outlined here, details for Task 1.3 are to be provided in a separate report being funded by this project, and procedures for Task 1.4 are assumed to be available to decommissioning personnel.

\subsubsection{Task 1.1 - Identify Primary and A1l Secondary Facilities within the Site}

Generally, the primary facility will be the facility under consideration for decommissioning and for which the ARCL test is being calculated. For any particular primary facility, the most highly contaminated 1-ha area 


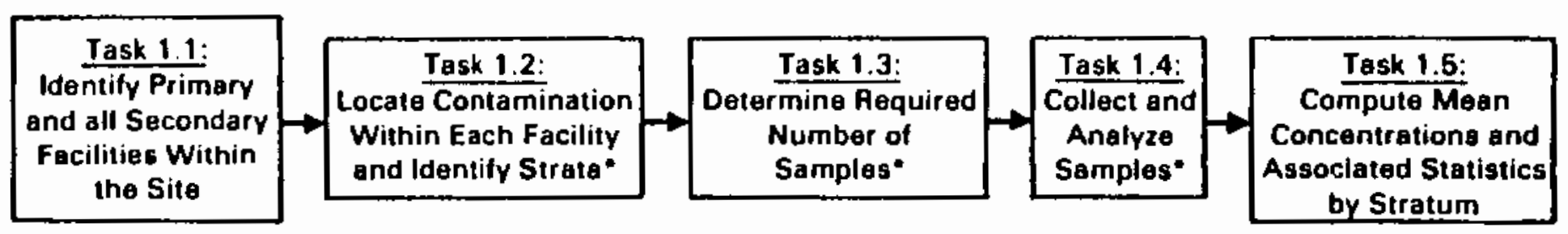

FIGURE 5.2. Tasks Required to Perform Activity 1 - Site Radionuclide Inventory Calculation. (Asterisks $\left(^{*}\right)$ indicate that detailed discussion the task is outside the scope of this manual) 
TABLE 5.2. Procedures Required for Activity 1 - Tasks $1.1-1.5$

Task 1.1 Identify Primary and All Secondary Facilities Within Site

1.1.1 Selection of 1-ha Site

1.1.2 Consideration of Specific Types of Secondary Facility

Task 1.2 Locate Contamination within Each Facility and Identify Strata

1.2.1 Generic - Locating Contamination

1.2.2 Generic - Identification of Strata

Task 1.3 Determine Required Number of Samples

1.3.1 Generic - Use of ARCL Sample Tables

Task 1.4 Collect and Analyze Samples

1.4.1 Generic - Sample Collection

1.4.2 Generic - Samp.le Analysis

Task 1.5 Compute Mean Concentrations and Associated Statistics

1.5.1 Preparation of Summary Statistics Tables

containing that facility will be identified. Other contaminated facilities within that 1-ha area will be referred to as secondary facilities.

\section{Procedure 1.1.1 Selection of 1-Ha Site}

The site to be considered in the ARCL calculation should contain the entire primary facility. If the primary facility is too large to be fully contained within 1 ha $\left(10,000 \mathrm{~m}^{2}\right)$, then the primary facility should be subdivided into 1-ha parcels. As a rule, the 1-ha area should be a regular polygon, no more than about three times as long as it is wide. Gerrymandering to include or exclude particular areas is discouraged. The 1-ha site may overlap that of another facility if several contaminated facilities are clustered in one area.

Procedure 1.1.2 Consideration of Specific Types of Secondary Facility

The purpose of ARCL determinations is to permit eventual unrestricted release of the $T$ and. If the primary facility facilities that are not intended to be released (such as reactor blocks or 
permanent waste burial grounds), then these "unreleasable facilities" should be specifically excluded from the determination of the 1-ha site.

\subsubsection{Task 1.2 - Locate Contamination Within Each Facility and Ident ify Strata}

For the primary and the secondary facilities in the 1-ha region, the extent (i.e., location, surface area, depth, etc.) of the contamination should be characterized. Portions of facilities classified as not contaminated should be such that, were physical samples to be collected and analyzed for specific radionuclides, "not-detectable" results would be obtained for all radionuclides.

The purpose of this step is to determine where the contamination is and where it is not. Noncontaminated areas of facilities may not have physical samples collected from them, (a) so it is important that only noncontaminated areas be so identified.

Actual procedures for surveying facilities are beyond the scope of this manual. Only a generic procedure is described.

\section{Procedure 1.2.1 GENERIC - Locating Contamination}

Facilities should be completely surveyed with field instrumentation. Areas with known histories of contamination, areas with measurable contamination, and representative noncontaminated areas should be identified.

Procedure 1.2.2 GENERIC - Identification of Strata

For the primary and each secondary facility, identify the rooms, areas, or portions of the facility having similar concentration levels. To do so, use knowledge of the operating history of the facility, survey instrument readings, prior or preliminary sample analysis results, etc. Group the areas having similar concentration levels into strata.

For ARCL testing purposes, it is most important that the information used to stratify each facility correlate well with the

(a) It is wise to collect and analyze a few samples from such areas to verify noncontamination. 
actual concentration levels of the dominating radionuclide(s). In practice, stratification may depend on physical or natural boundaries (e.g., rooms in a building which had the same function, or sludge, concrete, fill, etc., in a retention basin), as well as on concentration levels. Stratification provides the most benefits when the strata mean concentrations (of the dominant radionuclides) are quite different, and when the standard deviations of the concentration distributions (of the dominant radionuclides) within each stratum are small.

The purpose of this step is to provide for better characterization of the contamination, with the sampling and analysis effort expended where it will do the most good. The use of stratified random sampling will allow the ARCL dose to be estimated more accurately and with better precision than with ordinary simple random sampling.

\subsubsection{Task 1.3 - Determine Required Number of Samples}

Proper application of the ARCL method requires that an adequate number of physical samples be taken and radionuclide concentration determinations be performed. Step-by-step procedures for determining the number of analyses required for good statistical calculations are being prepared and will be presented in a separate report. A generic procedure is listed here to highlight the importance of this task.

Procedure 1.3.1 GENERIC - Use of ARCL Sample Size Tables

Use ARCL sample size tables or formulas described in Piepel (1986) to select the number of physical samples to be collected from each facility. Use sample size allocation formulas to determine what fraction of the total sample size should be taken from each stratum.

The data needs for estimating the radionuclide inventories of each facility should also be considered at this time. The ARCL sample size indicated for a given facility may be quite small (e.g., 2 or 3 samples) if it has little contamination in the dominant radionuclide. However, the need to estimate all inventories within a certain percentage of the true value may indicate that a larger sample size (than that required for ARCL testing) is needed. 
In most cases, taking both ARCL and inventory estimation needs into account, the minimum number of samples per stratum should be at least 5 . Otherwise, a final decision should consider the sample size numbers indicated by both ARCL and inventory estimation sample-size tables/ formulas.

\subsubsection{Iask 1.4 - Collect and Analyze Samples}

Sample collection and analysis procedures are assumed to be available to decommissioning personnel. Only generic procedure titles are included here to iTlustrate the importance of this step in ARCL determinations.

Procedure 1.4.1 GENERIC - Sample Collection

Collect the number of physical samples from each stratum as determined in Procedure 1.3.1.

Procedure 1.4.2 GENERIC - Sample Analysis

Analyze each sample for every radionuclide present in the facility, if possible. It is extremely important that direct or indirect (e.g., via double sampling) measurements be made on each sample for the dominant radionuclides.

\subsubsection{Task 1.5 - Compute Mean Concentrations and Associated Statistics}

Once sufficient samples have been obtained, the basic input values to the ARCL calculation of radionuclide inventory can be calculated. This must be done for each identified stratum within each facility in the 1-ha site.

Procedure 1.5.1 Preparation of Summary Statistics Table

Compute radionuclide concentration means, standard deviations, and covariances, and then fill out a Summary Statistics Table (see Figure 5.3) for each stratum.

Note that the nhi and the $n_{h i j}$ values for a given stratum will all be equal if each sample is analyzed for every radionuclide as suggested in Procedure 1.4.2. The ARCL test procedure can be carried out as long as $n_{h i}, n_{h i j} \geq 3$, but the results may be highly questionable, especially if only a small number of samples were analyzed for the dominant radionuc 1 ide (s). 


\section{Faru A - Sumary Statistics Tablo}

1. Facility and Stratua

2. Preparer's Nane:

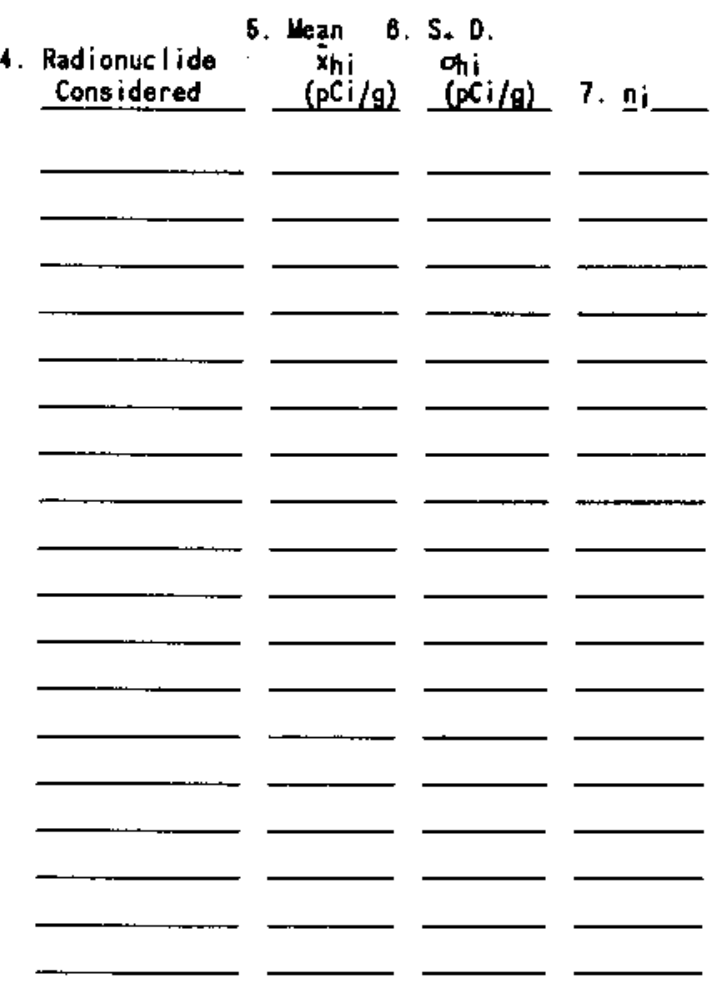

(a) Noto: Columes 8-11 vill be such longer than 4-7.
3. Date Prepared

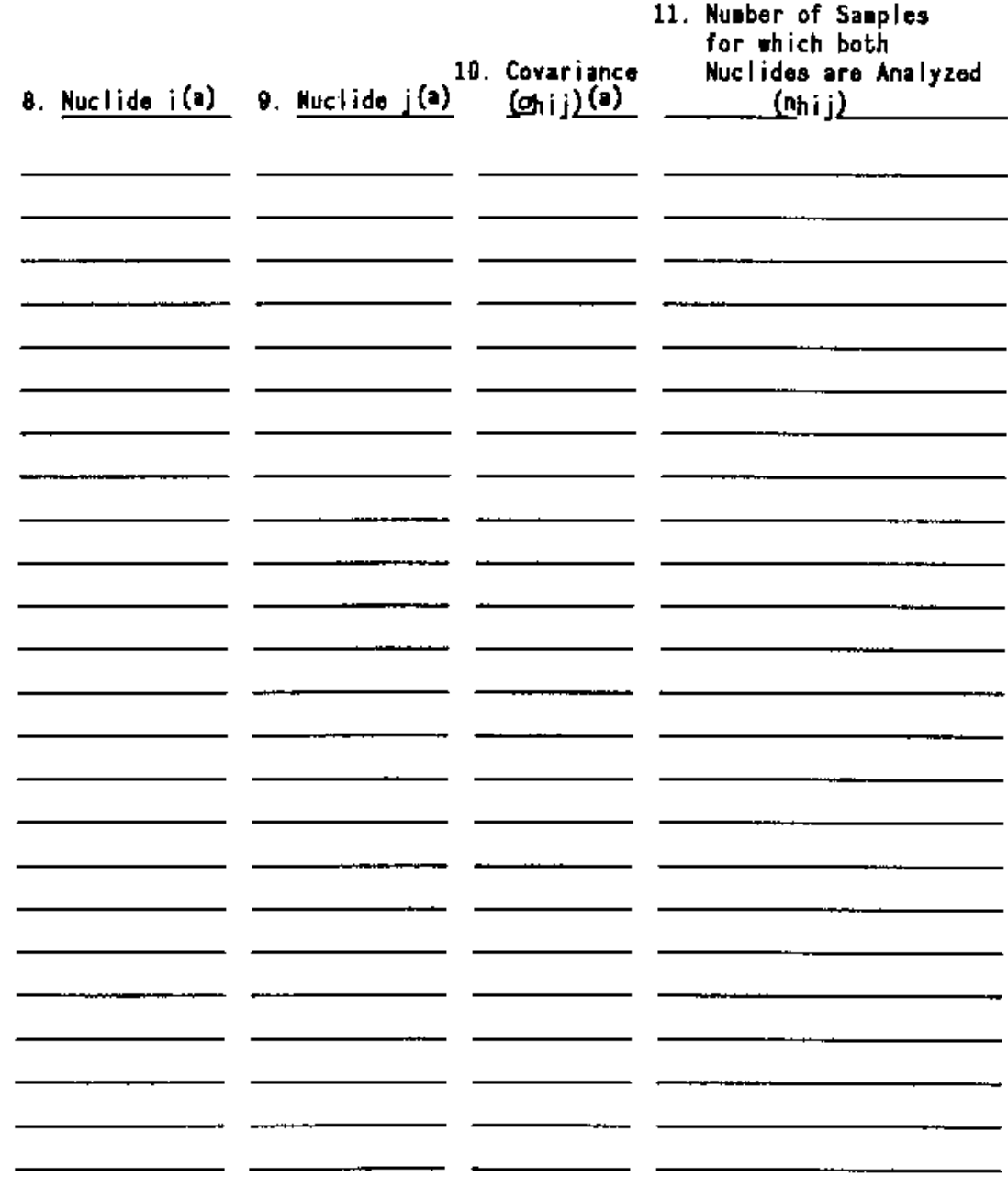

FIGURE 5.3. Form A - Sumay Statistics Table 
The calculation of the means and associated statistics should preferably be done automatically with a standard computer software package, with the results retained for the ARCL test process formulae. for completeness, the basic equations are repeated here from Section 4.3.

The mean concentration of radionuclide $i$ in stratum $h, x h i$, is given by

$$
\bar{x}_{h i}=\frac{1}{n_{h i}} \sum_{k=1}^{n_{h i}} x_{h i k}
$$

where $x_{h i k}=$ the concentration value of radionuclide $i$ from the $k$ th sample in stratum $h$ for which the concentration of radionuclide $i$ was determined (measured in $\mathrm{pCi} / \mathrm{g}$ ), and $n_{h i}=$ the number of samples in stratum $h$ for which the concentration of radionuclide $i$ was determined.

The estimated standard deviation $\left(\partial_{h i}\right)$ of the concentration values $x_{h i k}$ for radionuclide $i$ in stratum $h$, is given by

$$
\partial_{h i}=\left[\frac{1}{n_{h i}-1} \sum_{k=1}^{n_{h i}}\left(x_{h i k}-\bar{x}_{h i}\right)^{2}\right]^{1 / 2}
$$

The estimated covariances $\left(\partial_{h i}\right)$ of concentration values of radionuclides $i$ and $j$ in stratum $h$ are estimated as

$$
\partial_{h i j}=\frac{1}{n_{h i j}-1} \sum_{k=1}^{n_{h i j}}\left(x_{h i k}-\bar{x}_{h i}\right)\left(x_{h j k}-\bar{x}_{h j}\right)
$$

where $n_{h i j}$ is the number of samples from stratum $h$ for which concentration values of both radionuclides $i$ and $j$ are available. 


\subsection{ACTIVITY 2 - EXPOSURE SCENARIO SOURCE-TERM PREPARATION}

The three basic tasks required to prepare the source terms for the three ARCL exposure scenarios from the site inventories by stratum are illustrated in Figure 5.4. These tasks may be performed concurrently because each task requires the same input information. The procedures for implementing these tasks are listed in Table 5.3.

\subsubsection{Iask 2.1 - Prepare Source Terms for Residential/Home-Garden Scenario}

The residential/home-garden scenario is the most important scenario for instances of buried rubble or waste and for soil contamination. As described in Section 2, buried material is assumed to be excavated to the surface, distributed, and individuals are assumed to reside continuously in the contaminated area thus created. Materials distributed on the surface are assumed to contribute to the inventory unless they are of a form that is readily recognizable as a valuable recyclable commodity, in which case they are considered in the resource recycle scenario (Section 5.2.3). The following procedures are performed for each applicable stratum.

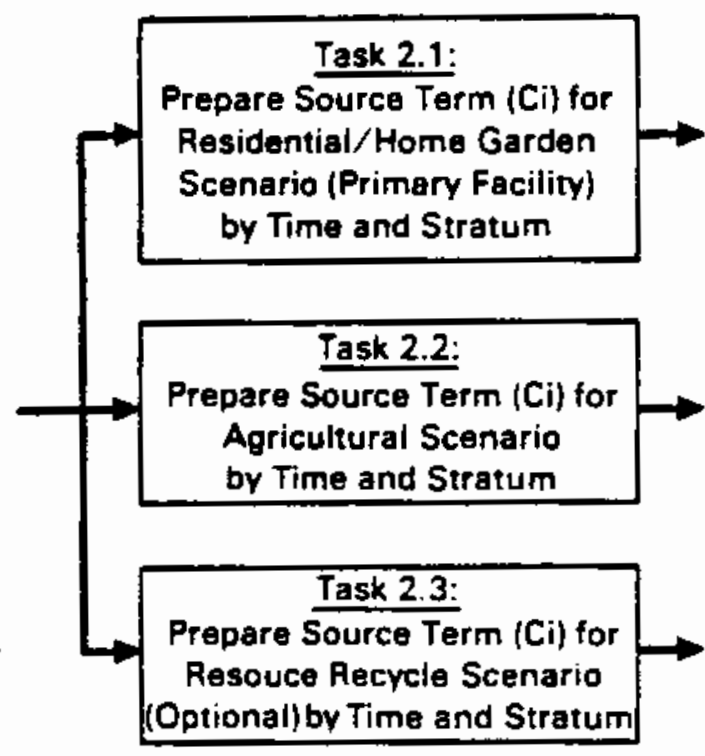

FIGURE 5.4. Tasks Required to Perform Activity 2 Exposure Scenario Source-Term Preparation 
TABLE 5.3. Procedures Required for Activity 2, Tasks $2.1-2.3$

Task 2.1 Prepare Source Terms for Residential/Home-Garden Scenario

2.1.1 Location of Scenario-Specified Excavation Volume

2.1.2 Calculation of Residential/Home-Garden Scenario Source Terms

2.1.3 Decay Adjustments to Source Term

Task 2.2 Prepare Source Term for Agricultural Scenario

2.2.1 Calculation of Agricultural Scenario Source Terms

(2.1.3) Decay Adjustments to Source Term

Task 2.3 Prepare Source Term for Resource Recycle Scenario

2.3.1 Calculation of Resource Recycle Source Term

(2.1.3) Decay Adjustments to Source Term

Procedure 2.1.1 Location of Scenario-Specified Excavation Volume

1dentify the location of the $10 \times 20 \times 5-m$ basement excavation volume within the 1-ha site expected to yield the largest dose. For situations where a single radionuclide dominates the dose calculations, this is equivalent to identifying the $10 \times 20 \times 5-m$ volume containing the largest inventory of the dominant nuclide. Nomally, the product of inventory and dose factor is used to determine the location of greatest dose potential. This accounts for differences in radionuclide inventory and hazard.

Procedure 2.1.2 Calculation of Residential/Home-Garden Scenario Source $\underline{\text { Termins }}$

Determine the mass of the stratum (considering only contaminated material) that is in the selected $10 \times 20 \times 5-m$ excavation volume. This step makes use of the precise characterization information (areas, depths, concentrations, etc.) of contaminated portions of facilities performed in Activity 1 . The equation for calculating the inventory, $\mathrm{y}_{i}$, of radionuclide $i$ by stratum is

$$
y_{i}=m_{h} \bar{x}_{h i}
$$


The standard deviation on the estimated inventory of radionuclide $i$ by stratum is calculated using

$$
D\left(y_{h i}\right)=\left[\frac{m_{h}^{2} \hat{\sigma}_{h i}^{2}}{n_{h i}}\right]^{1 / 2}
$$

where the mean concentration, $x_{h i}$, the concentration standard deviation of radionuclide $i$ in stratum $h, \partial_{h i}$, and the number of samples of radionuclide $i$ in stratum $h, n_{h i}$, are taken from worksheet $A$, the Summary Statistics Tables, (see Figure 5.3) for each stratum prepared in Procedure 1.5.1, and where $m_{h}=$ the mass of stratum $h$.

Enter the results on the Source-Term Worksheet (Form B), shown in Figure 5.5. Separate worksheets should be used for each stratum considered. If there is insufficient space on a worksheet, simply append additional copies.

For strata including radionuclides encased in material making them unavailable (for instance, contamination inside of closed pipes), consideration in the source term must be given to the ultimate availability of the contained radionuclides. The effects of radioactive decay until the material becomes available should be considered. For selected situations, the increasing availability compounded with decay may mean that the potential dose rate could peak at a time other than that chosen for site release. Iterative examination of the dose rate may be required to assure that the most restrictive time period is used in the calculation.

\section{Procedure 2.1.3 Decay Adjustments to Source Term}

The entries in Items 10 and 11 of Form B, Figure 5.5, represent the currently measured source term. However, decommissioning planning may incorporate consideration of a period of institutional control. The radionuclide inventory would be decayed to some level lower than that existing today. The effect of radioactive decay on the source inventory for a mixture of radionuclides is next determined. 
Forn B-Source-Tern Yorksheet

1. Facility/Scenario and Stratun:

2. Preparer's Nams:

3. Date Prepared:

4. Stratun Hass ${ }^{(a)}$ (grans):

5. Nunber of Years of Decay: (t)

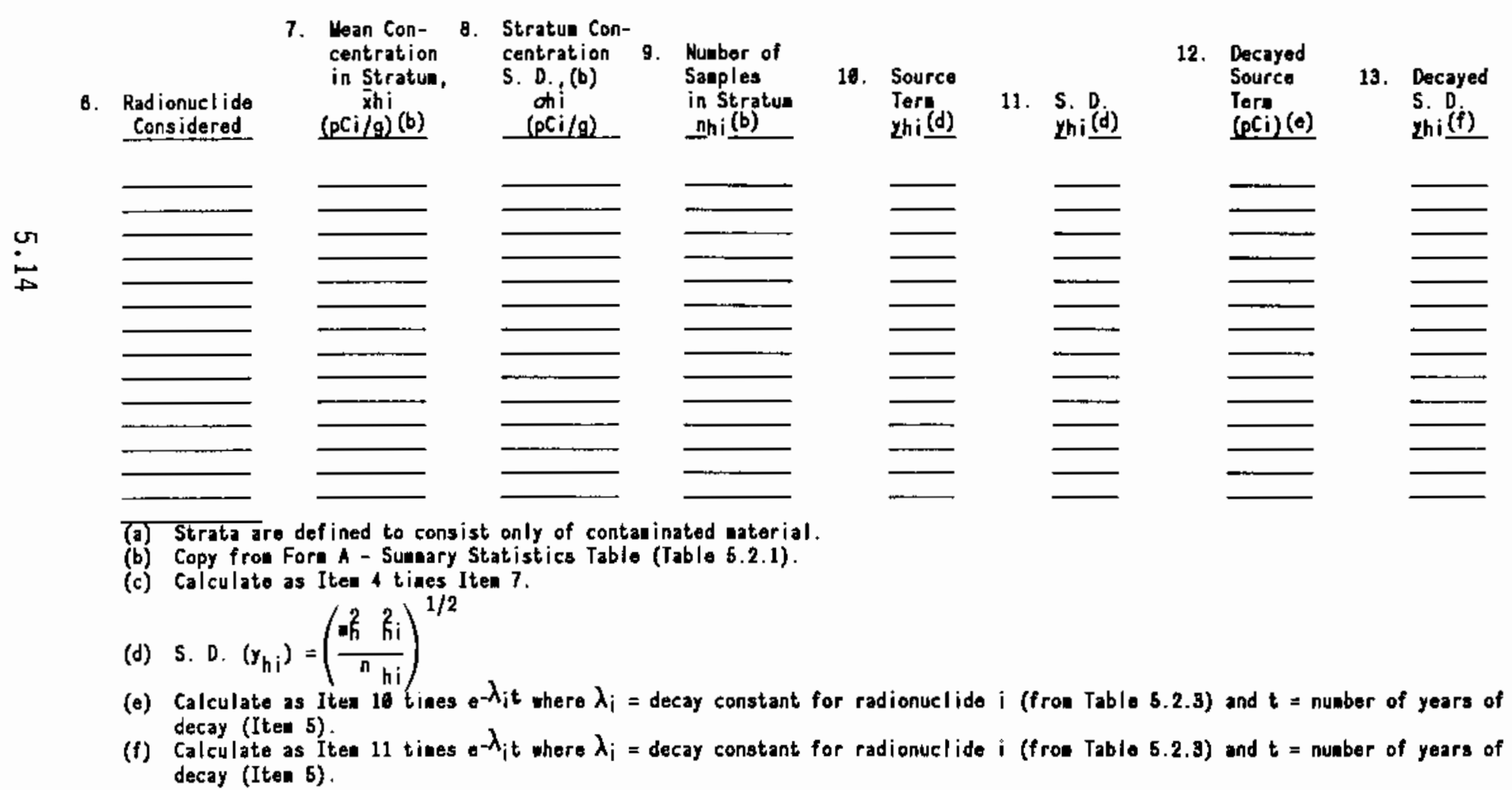

FIGURE 5.5. Form B - Source-Term Worksheet 
To calculate the decayed source term and standard deviations, simply multiply the entries in Items 10 and 11 of Form B, Figure 5.5, by the term $\left(e^{-\lambda_{j}} t\right)$ where $\lambda_{i}$ equals the decay constant for radionuclide $i$ (from Table 5.4) and $t$ equals the number of years of radioactive decay (Item 5 of Form B, Figure 5.5).

\subsubsection{Task 2.2 - Prepare Source Terms for Agricultural Scenario}

Application of the agricultural scenario is a procedural way of assuring that no contribution from residual contamination within the 1-ha site is omitted from consideration, since it is not directly accounted for in the residential/home-garden scenario. The same person assumed to be living in the contamination from the residential/home-garden excavation is simultaneousty exposed to any other sources through the crop-uptake pathway. The source-term calculation, and decay adjustments, are parallel in structure for the agricultural scenario with those for the residential/home-garden scenario. The decay procedure is, in fact, identical and so is not repeated. For the rare case of surface contamination, source terms for external and inhalation doses can be prepared in an analagous fashion.

\section{Procedure 2.2.1 Calculation of Agricultural Scenario Source Terms}

Determine the mass of the stratum (considering only contaminated material) remaining in the 1 -ha area, once the $10 \times 20 \times 5-m$ volume has been removed. For certain circumstances, it may be advantageous to define more than one stratum, as a function of depth. The equations for calculating the total source term of each radionuclide are those described in Procedure 2.1.1. The results should be entered on separate copies of Form B, the Source Term Worksheet (Figure 5.5), by stratum.

\subsubsection{Task 2.3 - Prepare Source Terms for Resource Recycle Scenario}

Selected waste forms, such as piping, activated metal components, and other sources of contained activity, are not amenable to the agricultural activities of the residential/home-garden or agricultural scenarios until the waste form decomposes. The wastes may be stable solids which would not be dispersed during excavation and which would not allow root uptake by plants. Materials such as this may be included in the agricultural scenario by way of 
TABLE 5.4. Decay Constants for Selected Radionuclides $\left(\mathrm{yr}^{-1}\right)$

\begin{tabular}{|c|c|c|c|}
\hline Nuclide & Constant & Nuclide & Constant \\
\hline $3 \mathrm{H}$ & $5.6 \mathrm{E}-2$ & ${ }^{134} \mathrm{Cs}_{5}$ & $3.4 \mathrm{E}-1$ \\
\hline $14 \mathrm{C}$ & $1.2 \mathrm{E}-4$ & $135 \mathrm{Cs}$ & $3.4 \mathrm{E}-7$ \\
\hline $36 \mathrm{Cl}$ & $2.2 \mathrm{E}-6$ & ${ }^{137} \mathrm{C} 5+\mathrm{D}$ & $2.3 \mathrm{E}-2$ \\
\hline $57 \mathrm{Co}$ & $9.3 \mathrm{E}-1$ & ${ }^{144} \mathrm{Ce}$ & $8.9 \mathrm{E}-1$ \\
\hline $60 \mathrm{Co}$ & $1.3 \mathrm{E}-1$ & $152 \mathrm{Eu}$ & $5.2 \mathrm{E}-2$ \\
\hline $55 \mathrm{Fe}$ & $2.6 \mathrm{E}-1$ & $154 \mathrm{Eu}$ & $8.5 E-2$ \\
\hline${ }^{59} \mathrm{Fe}$ & $5.6 \mathrm{E}+0$ & $226 \mathrm{Ra}$ & $4.3 \mathrm{E}-4$ \\
\hline${ }^{59} \mathrm{Ni}$ & $8.7 E-6$ & $232 \mathrm{Th}$ & $5.0 \mathrm{E}-4$ \\
\hline $63 \mathrm{Ni}$ & $6.9 E-3$ & $235 u+D$ & $9.8 \mathrm{E}-10$ \\
\hline $90 S r+D$ & $2.4 E-2$ & $238 U+D$ & 1. $6 \mathrm{E}-10$ \\
\hline 93Мо & $2.0 \mathrm{E}-4$ & $237 N p+D$ & $3.2 \mathrm{E}-7$ \\
\hline $94 \mathrm{Nb}$ & $3.5 \mathrm{E}-5$ & $238 \mathrm{Pu}$ & $7.9 \mathrm{E}-3$ \\
\hline${ }^{99} \mathrm{TC}$ & $3.2 \mathrm{E}-6$ & $239 \mathrm{Pu}$ & $2.9 E-5$ \\
\hline $124 \mathrm{Sb}$ & $4.2 E+0$ & $241_{\mathrm{Am}}$ & $1.6 \mathrm{E}-3$ \\
\hline $125 s b+0$ & $2.5 \mathrm{E}-1$ & & \\
\hline
\end{tabular}

Form C, the Availability Correction Worksheet (Figure 5.7), or they may be included in the resource recycle scenario. This scenario considers exposures to persons other than the onsite resident, and the doses are calculated independently and compared to the overall annual dose limit without being summed with the onsite values. The mechanics of the source-term preparation, and optional decay correction, are the same as described for the other two scenarios in Sections 5.2.1 and 5.2.2. The decay procedure 2.1.3 is used if needed.

Procedure 2.3.1 Calculation of Resource Recycle Source Terms

Oetermine the mass of material that could potentially be recycled if discovered by the onsite resident. The general equations for converting from concentration to source term by stratum are those described in Procedure 2.1.2. The results should be entered on separate copies of Form B, the Source Term Worksheet (Figure 5.5), by stratum. This procedure is optional--if there are no waste forms within the 1-ha site which 
can be reasonably considered to be recyclable (e.g., for crib sites), this scenario may be omitted.

\subsection{ACTIVITY 3 - RESIDENTIAL/HOME-GARDEN SCENARIO CALCULATION}

The two tasks required to perform the actual calculation of the dose estimate to the resident individual for the residential/home-garden scenario are illustrated in Figure 5.6. The procedures for implementing these tasks are listed in Table 5.5 .

\subsubsection{Task 3.1 - Apply Availability Correction to Radionuclide Dose Factors}

Most waste forms for which an availability correction would apply should also be considered for the resource recycle scenario. Wastes such as activated metals may more properly be considered there. If they are included in the residential/home-garden scenario, the dose factors of specific radionuclides contained in the actuated metals may be reduced by a factor relating their corrosional release rate to soil.

Procedure 3.1.1 Application of Availability Correction Worksheet

Radionuclides contained in chunks of metal will not be available for resuspension or root uptake even if distributed on the surface by excavation. Metal pieces corrode slowly with time, gradually releasing the contained materials. For a particular waste strata (for instance, a pipe), determine a representative waste form thickness. This may be an average over several sizes. Calculate the reduction factor RF for radionuclides incorporated in this waste form at the time of interest. $t$, using the equation

$$
\mathrm{RF}=2 \mathrm{t} \text { (corrosion rate, } \mathrm{cm} / \mathrm{yr} \text { )/(thickness, } \mathrm{cm} \text { ) }
$$

Note that this correction should never be greater than 1 .

Enter this value only for affected radionuclides in Column 5 of Form C, the Availability Correction Worksheet (shown in Figure 5.7). All other entries in Column 5 should be 1.0. Calculate the adjusted inhalation/external and ingestion dose factors and final scenario dose 


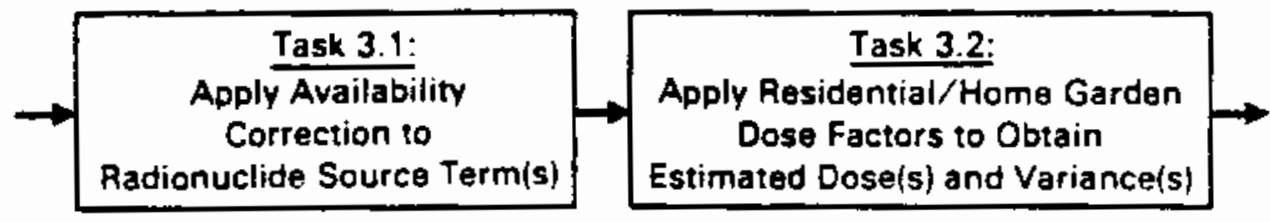

FIGURE 5.6. Tasks Required to Perforta Activity 3 - Residential/ Home-Garden Scenario Calculation

TABLE 5.5. Procedures Required for Activity 3, Tasks $3.1-3.2$

Task 3.1 Apply Availability Correction

3.1.1 Application of Availability Correction Worksheet

Task 3.2 Apply Residential/Home-Garden Dose Factors

3.2.1 Application of Stratum Dose Calculation Worksheet to Residential/Home-Garden Scenario

\subsubsection{Calculation of Variance of Estimated Dose}

factors. The scenario dose factors for the residential/home-garden scenario are the sum of Columins $7 \mathrm{a}$ and $7 \mathrm{~b}$.

\subsubsection{Task 3.2 - Obtain Residential/Home-Garden Dose Estimates}

Radiation dose estimates are calculated for each stratum.

Procedure 3.2.1 Application of Stratum Dose Calculation Worksheet to Residential/Home-Garden Scenario

The Stratum Dose Calculation Worksheet (Form D) is illustrated as Figure 5.8. Radionuclide names, source terms by stratum, and standard deviations by stratum should be entered from (Form B) the Source-Term Worksheets (Figure 5.5). The scenario dose factors for Column 7 should be entered from Form $C$, the Availability Correction worksheet (Figure 5.7, column 8). The total estimated dose can be obtained as the sum of the entries in Column 8 of Form D, the Stratum Dose Calculation Worksheet (Figure 5.8); the values in Column 10 of that worksheet are 
Forn C - Availability Correction lorkshoot

1. Facility/Sconario and Stratun:

2. Preparer's Nano:

3. Date Prepared:

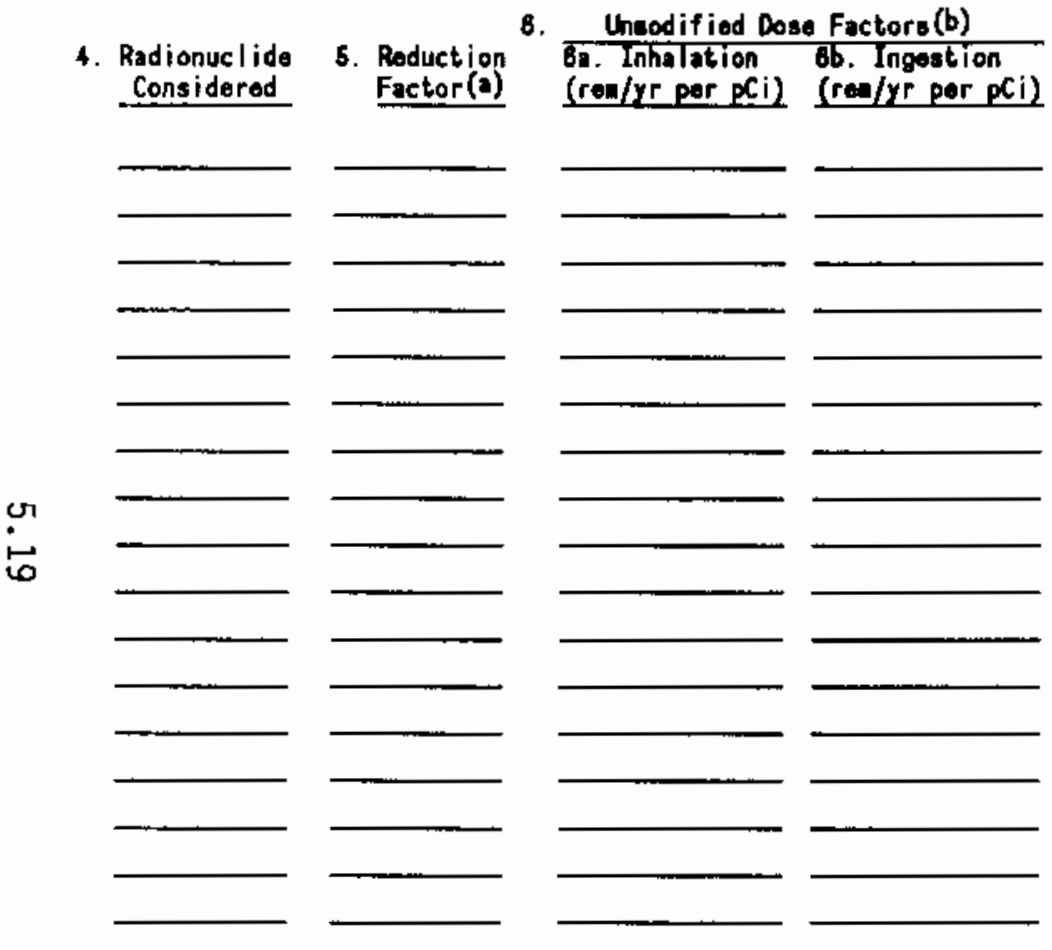

7. Corrected Dose Factore(c) 7.. Inhalation 7b. Ingostion (reo/yr per pCi) (reo/yr per pCi)

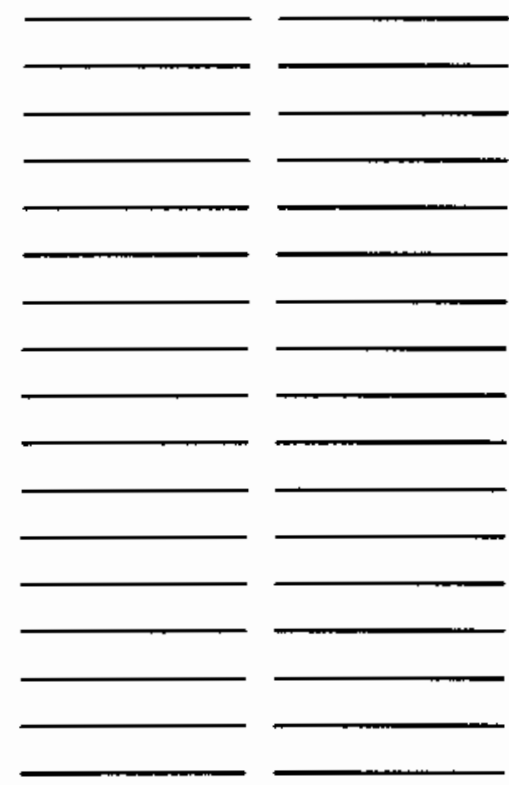

9. Rosidential/Howe Garden (a) Sconario Dosa Factors. (rea/yr per pCi)

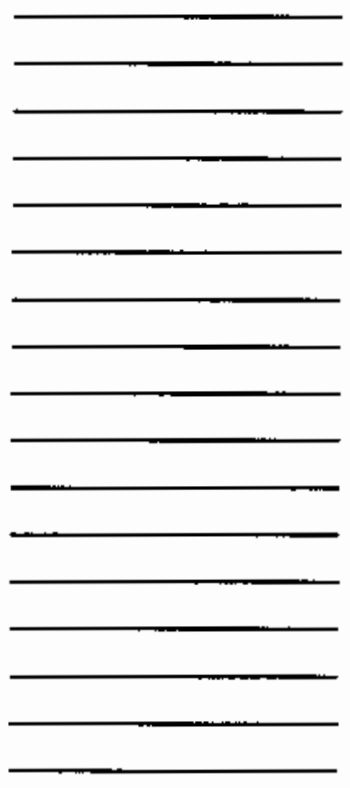

(a) $F F=1.0$ for radionucl ides not conta ined in activated aetals. $\mathrm{RF}=2 \mathrm{t}$ (corrosion rate ce/yr)/(thickness in $\mathrm{cs}$ ).

(b) Fron Table 2.2

(c) Calculatod as the product of coluans $\delta$ and 8 , by radionuclide.

(d) Complete this colum only for the Residential/hose Garden scenario. The scenario doso factora are calculatod as Coluan 7 a plus coluen 76 .

\section{FIGURE 5.7. Form C - Availability Correction Worksheet}


Fora D - Stratun Doso Calculation Worksheet

1. Facility/Scenario and Stratua:

2. Properer's Nane:

3. Date Preparod:

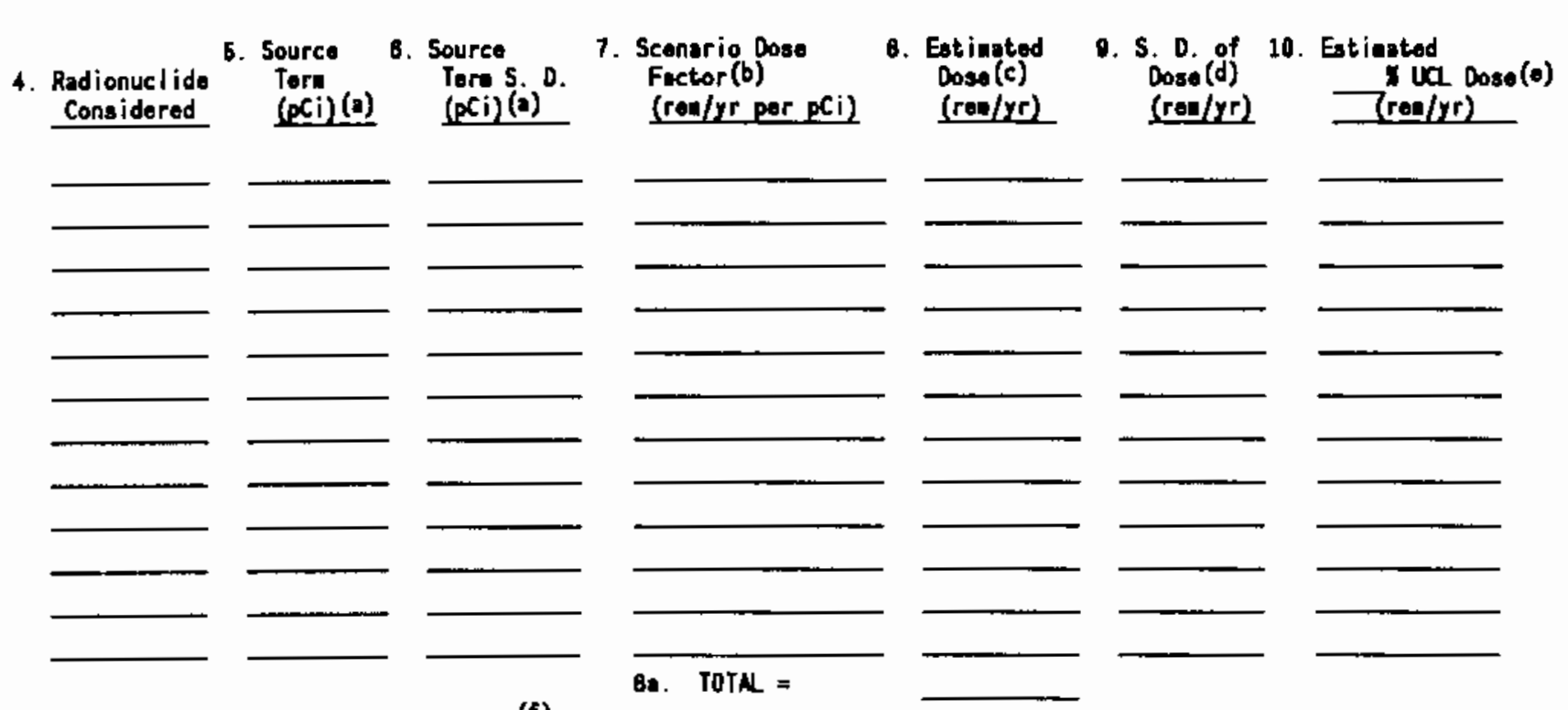

11. Variance of Eatinated Dose $(r e a / y r)^{2}(f)$ :

(a) Fros For B - Source Torn Iorkeheet (coluan 10 or 12), for $\mathrm{T}=$

years.

(b) Fron Forn C - Availability, Fore F - Aren, Forn O - Depth, or Forn H- Mase Correction Forksheets, as appropriate.

(c) Calculate as the product of Coluens $B$ and 7 .

(d) Calculate as the product of Coluans 6 ind 7 .

(o) Caleulate as (Coluan $\theta)+z_{1-\alpha}\left(\right.$ Coluan 9 ), there $z_{1-\alpha}$ is chosen to correspond with the desired conf idence lovol from Table 5.5 .

(f) Calculate using Procedure 3.2.2, Coluans 7, 9, and Coluana 8, 9, 10, and 11 frow Fora A - Sumary Statiatica Torksheot on Forn $E$ (Dose Variance Calculation Norkshoet.

FIGURE 5.8. Form D - Stratum Dose Calculation Worksheet 
not necessary for the remainder of the caiculation, but may be calculated if information on the dominant radionuclides is desired. Values for Column 10 may be calculated as Column 8 plus $z_{1-a}$ times Column 9 , where $z_{1-a}$ may be obtained from Table 5.6, below.

TABLE 5.6. Standard Normal Distribution Values $z 1-\alpha$ Such that $(1-a) 100 \%$ of the Distribution Lies to the Left of $Z_{1-a}$

\begin{tabular}{cl}
$(1-a) 100 \%$ & $\frac{Z_{1-a}}{2.33}$ \\
\hline 99 & 1.96 \\
97.5 & 1.645 \\
95 & 1.282 \\
90 &
\end{tabular}

The value for Item 11 of Form D, the Stratum Dose Calculation Worksheet (Figure 5.8), is required if the upper confidence limit for a stratum, scenario, or site is to be calculated. The calculation of Item 11 is complex, and is described in Procedure 3.2.2.

Procedure 3.2.2 Calculation of Variance of Estimated Dose:

This procedure is to define the calculation required to compute Item 11 of Form D, the Stratum Dose Calculation Worksheet (see Figure 5.8). As described in Section 4, the value of the UCL of dose for stratum $h$ is determined as

$$
U C L_{h}=\hat{t}_{h}+S D\left(\hat{\theta}_{h}\right) * z_{1-\alpha}
$$

where the estimated standard deviation of $\hat{t}_{h}, S D\left(\hat{D}_{h}\right)$ is determined from the equation

$$
\operatorname{SO}\left(\hat{\theta}_{h}\right)=\left[\operatorname{Var}\left(\hat{\theta}_{h}\right)\right]^{1 / 2}
$$

and

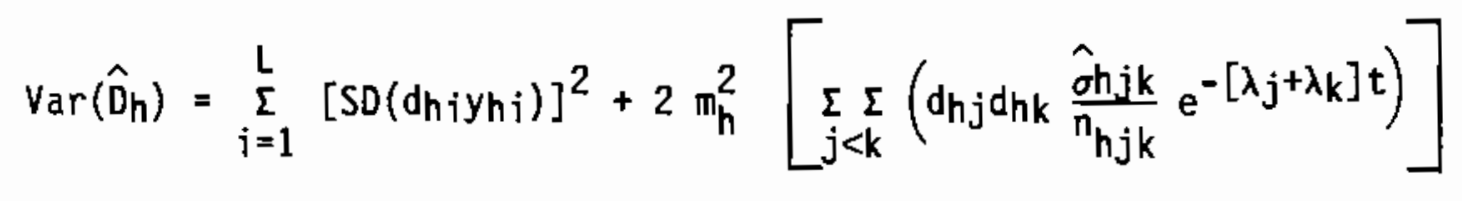


where $S D($ dhiyhi$)=$ the standard devia ion of the individual radionuclide dose estimates for stratum $h$, from Column 9 of Form $D$, the Stratum Dose Calculation Worksheet (Figure 5.3),

$m_{h}=$ the mass of stratum $h$, Item 4 of Form $B$ from the Scenario Source Term Worksheet (Figure 5.3),

$\mathrm{dh}_{\mathrm{i}}=$ the scenario dose factor for radionuclide $i$, from Column 7 of Form D, the Stratum Dose Calculation Worksheet (Figure 5.8),

$\partial_{\text {hik }}=$ the estimated covariances between concentrations of radionuclides $j$ and $k$ in stratum $h$ from Column 10 of Form A, the Summary Statistics Table (Figure 5.3), $n_{h j k}=$ the number of samples from strata $h$ for which both radionuclides $j$ and $k$ were analyzed, from Column 11 of Form $A$, the Summary Statistics Table (Figure 5.3),

$L=$ the total number of radionuclides, from form $A$, the Sunanary Statistics Table (Figure 5.3),

$\lambda_{j}=$ the decay constant for radionuclide $j$ or $k$, from Table 5.4,

$t=$ the time after the measurements were taken, corresponding to the time for which the dose, $D$, was estimated, from Item 5 of Form B, the Source-Term Worksheet (Figure 5.5).

when all values are tabulated, the variance may be calculated and inserted in Item 11 of the worksheet. Form $E$, the Dose Variance Calculation Worksheet (Figure 5.9), can be used to solve Equation 5.9. However, the use of a computer is encouraged for this calculation.

The $100(1-\alpha) \%$ UCL on dose can be calculated using any desired confidence limit. The multiplier $z_{1-\alpha}$ for several commonly chosen confidence limits is given in Table 5.6. 
Form E - Dose Variance Calculation Worksheet

1. Facility and Stratum:

2. Preparer's Mame: 3. Date Prepared:

4. Stratum Mass (mh): g 5. Oecay Time $(t)$ : y

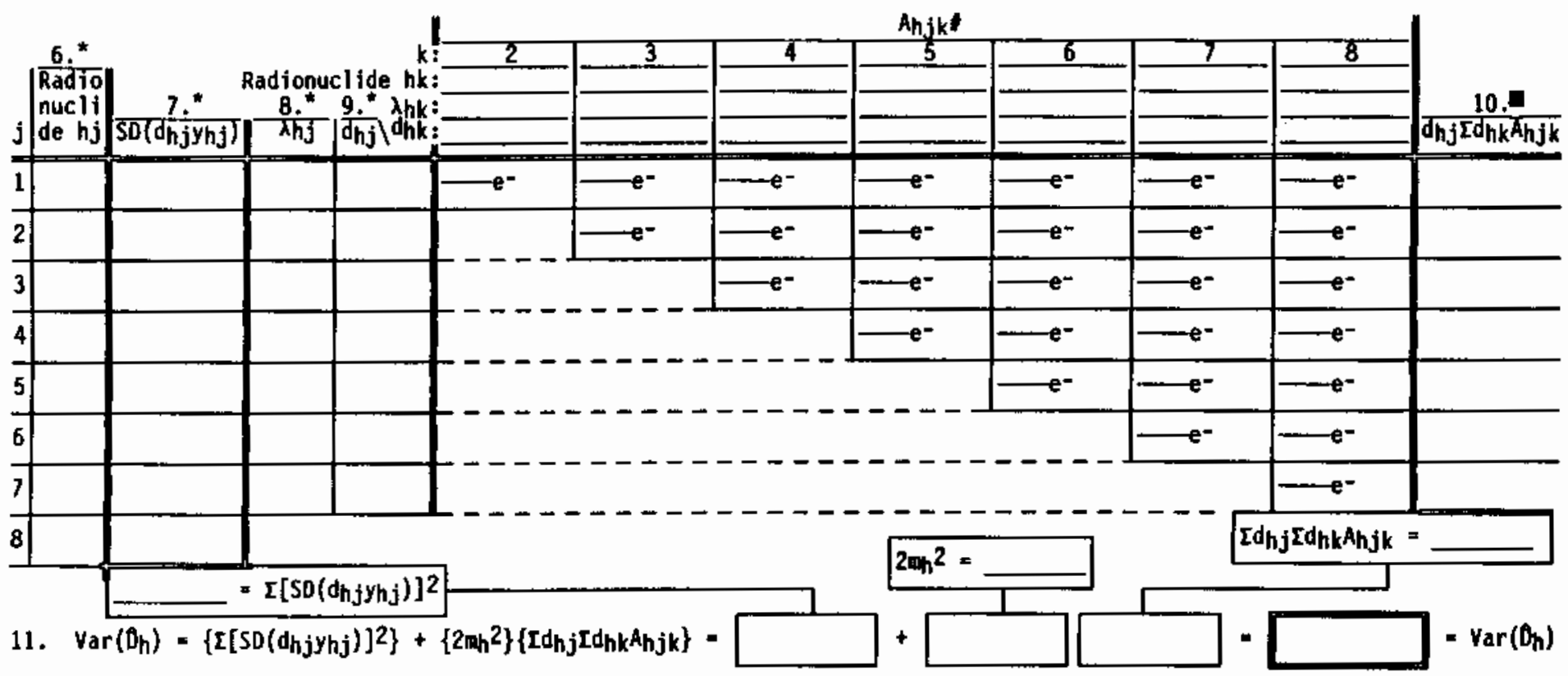

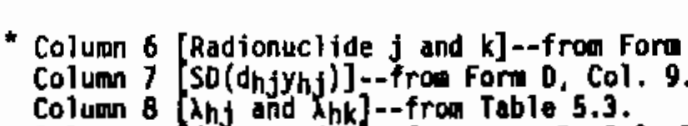

Colunn 9 [dhj and dhk]--from Fora D, Col. 7.

- Ahjk $=\frac{\hat{\sigma}_{h j k}}{n_{h j k}} e^{-\theta}$, where $\hat{\sigma}_{h j k}$ is from Form B, Col. 10 , nhjk is from Form $B ;$ Col. 11, and

- Coluan 10--ćalculated as $d_{h j}{ }^{2} d_{h k} A_{h j k}$.

\section{FIGURE 5.9. Form E - Dose Variance Calculation Worksheet}




\subsection{ACTIVITY 4 - AGRICULTURAL SCENARIO CALCULATION}

The four tasks required to perform the calculation of the dose estimate to the resident individual for the scenario of exposure to all other residual contamination on the 1-ha site, exclusive of that contained in the $10 \times 20 \times 5-m$ excavation, are illustrated in Figure 5.10. The procedures for implementing these tasks are listed in Table 5.7 .

\subsubsection{Task 4.1 - Apply Availability Correction to Radionuclide Dose Factors for Agricultura] Scenario}

The availability correction as described for the residential/home-garden scenario also applies to radionuclides contained within activated components for the agricultural scenario. The Availability Correction Worksheet (shown in Figure 5.7), with its controlling Procedure 3.1.1, is used. Because there is assumed to be no contamination of surface soils, as should usually be the case, calculation of the inhalation/external dose factors may be omitted. For the special case where surface soil contamination does exist, the inhalation/external dose factors must be included. These can be obtained from Table 2.1, with corrections for area being applicable. Column 8 of the Availability Correction Worksheet (Figure 5.7) may be omitted, except for cases of surface contamination.

\subsubsection{Task 4.2 - Apply Area Correction to Radionuclide Dose Factors}

The ingestion dose factors derived in Section 2 of this report are presented in terms of $\mathrm{rem} / \mathrm{pCi}$, where the activity is implicitly assumed to be distributed over an area of 1 ha. If strata for the agricultural scenario covers an area less than 1 ha, then the dose factors may be reduced using the Area Correction Worksheet, shown in Figure 5.11, for those strata.

\section{Procedure 4.2.1 Application of Form F - Area Correction Worksheet}

The derivation of the area correction factor is discussed in Section 2. Dose factors for all radionuclides are adjusted by the same area correction. Dose factors input to Form $F$, the Area Correction Worksheet (Figure 5.11) should come from Forml $C$, the Availability Correction Worksheet (Figure 5.7). The equation given for Item 5 in the Area Correction Worksheet is simply the paraneterization of the graph shown in Figure 2.3 . 


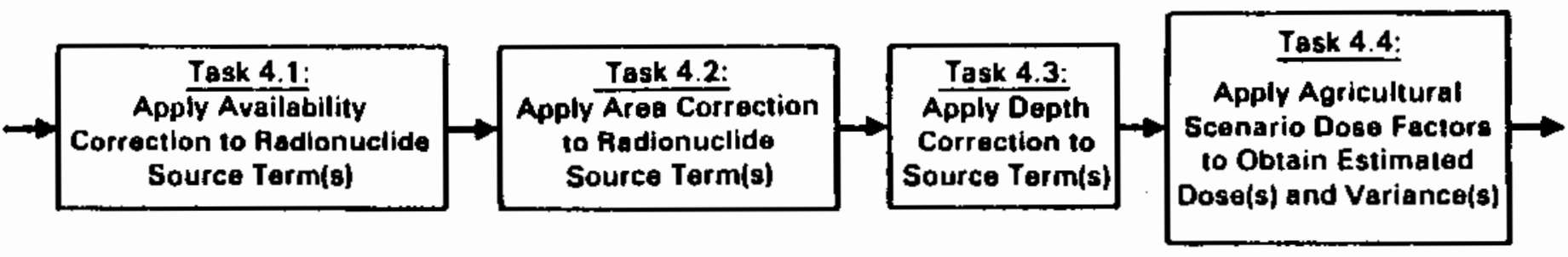

FIGURE 5.10. Tasks Required to Perform Activity 4 - Agricultural Scenario Option 
TABLE 5.7. Procedures Required for Activity 4, Tasks $4.1-4.4$

Task 4.1 Apply Availability Correction to Radionuclide Dose Factors

(3.1.1) Application of Availability Correction Worksheet

Task 4.2 Apply Area Correction to Radionuclide Dose Factors

4.2.1 Application of Area Correction Worksheet

Task 4.3 Apply Depth Correction to Radionuclide Dose Factors

4.3.1 Application of Depth Correction Worksheet

Task 4.4 Apply Agricultural Scenario Dose Factors

4.4.1 Application of Stratum Dose Calculation Worksheet to Agricultural Scenario

(3.2.2) Calculation of Variance of Estimated Dose

\subsubsection{Task 4.3 - Apply Depth Correction to Radionuclide Dose Factors}

The ingestion dose factors derived in Section 2 of this report are nomalized to $100 \%$ root uptake, which implies that the contaminated soil in which the plants are growing extends completely to the surface. For sites with a clean overburden layer, an adjustment may be made to the ingestion portion of the dose via the dose factors, using Form $G$, the Depth Correction Worksheet (Figure 5.12). This correction must be made for each stratum. Note that "overburden" includes overlying strata, if considered.

Procedure 4.3.1 Application of Depth Correction Worksheet

The derivation of the depth correction factor is discussed in Section 2. Ingestion dose factors for all radionuclides for one stratum are adjusted by the same depth correction. Dose factors input to Form G, the Depth Correction Worksheet (Figure 5.12), should come from Form $F$, the Area Correction Worksheet (Figure 5.11), if used, otherwise from Form $C$, the Availability Correction Worksheet (Figure 5.7). The equation presented in Item 5 on Form $G$, the Depth Correction Worksheet, is simply a parameterization of the graph presented in Figure 2.2. 


\section{Form F - Area Correction Worksheet}

1. Facility:

2. Preparer's Name:

3. Date Prepared:

4. Area of Contamination Within 1-ha Site $m^{2}=$ ha

5. Correction Factor $=0.1+9($ Item 4$)=$

6. Radionuclide

7. Ingestion $\mathrm{DF}(\mathrm{rem} / \mathrm{yr} / \mathrm{pCi})(\mathrm{a})$

8. Corrected Ingestion $\mathrm{DF}(\mathrm{rem} / \mathrm{yr} / \mathrm{pCi})(\mathrm{b})$
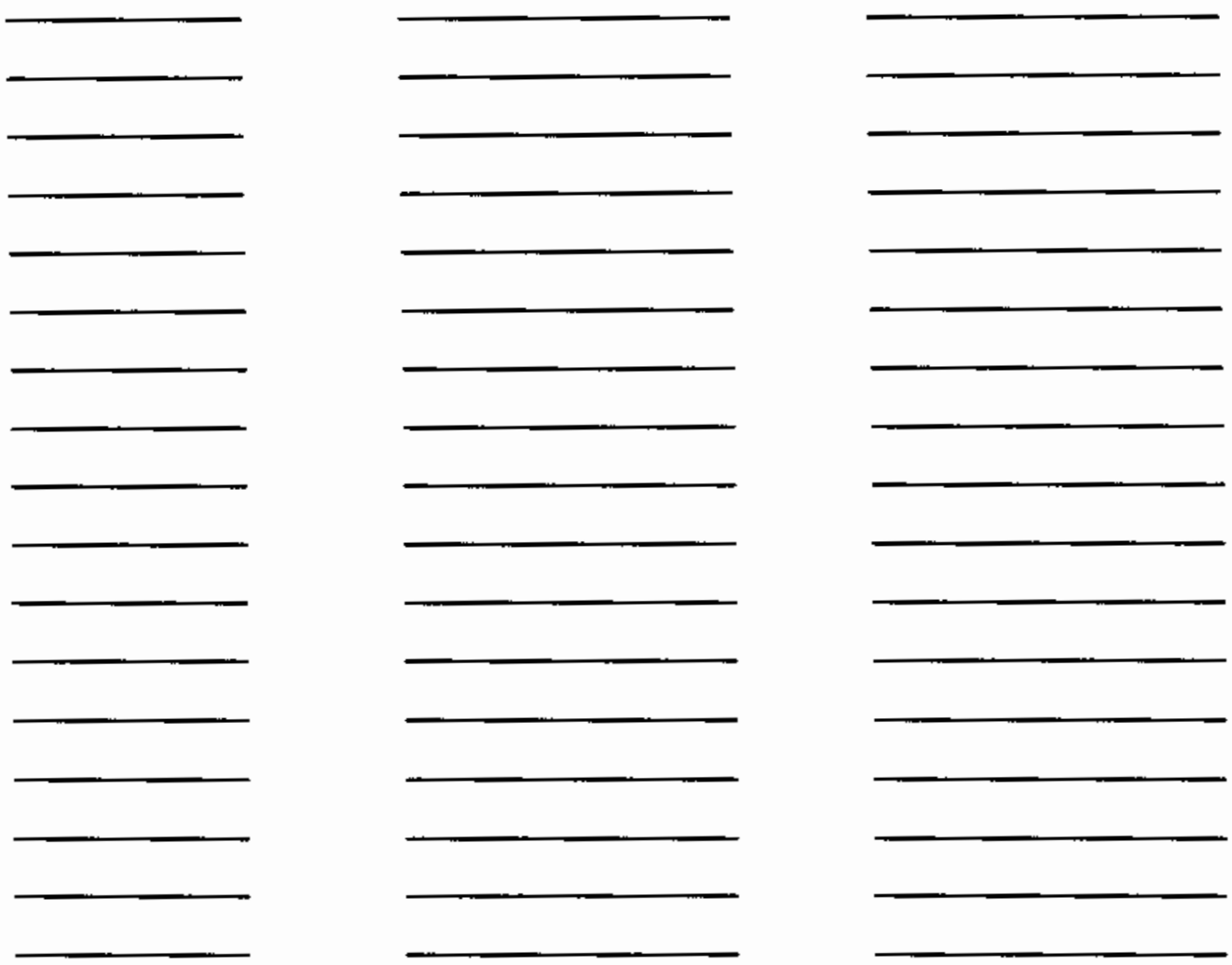

(a) From Availability Correction Worksheet Form C.

(b) Calculated as Item 5 times Column 7.

FIGURE 5.11. Form F - Area Correction Worksheet 


\section{Facility:}

2. Preparer's Name:

3. Date Prepared:

4. Depth of Clean overburden m.

5. Calculate depth correction factor (DCF) as DCF $=\mathrm{e}^{-0.92(\text { Depth) }}=$

If Depth $>10$ meters DCF $=0.0$.

6. Radionuclide
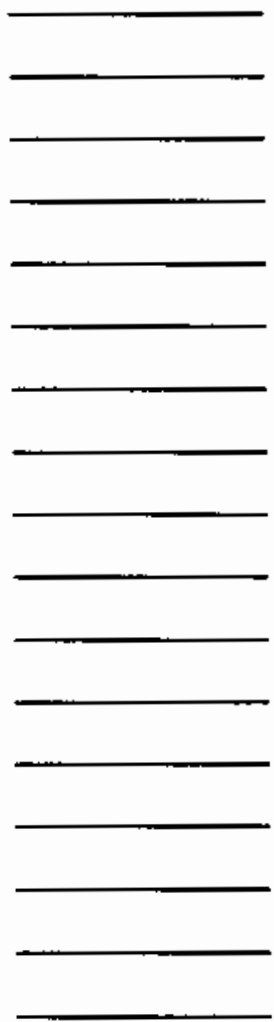

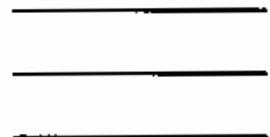

7. Ingestion OF $(\mathrm{rem} / \mathrm{yr} / \mathrm{pCi})(\mathrm{a})$

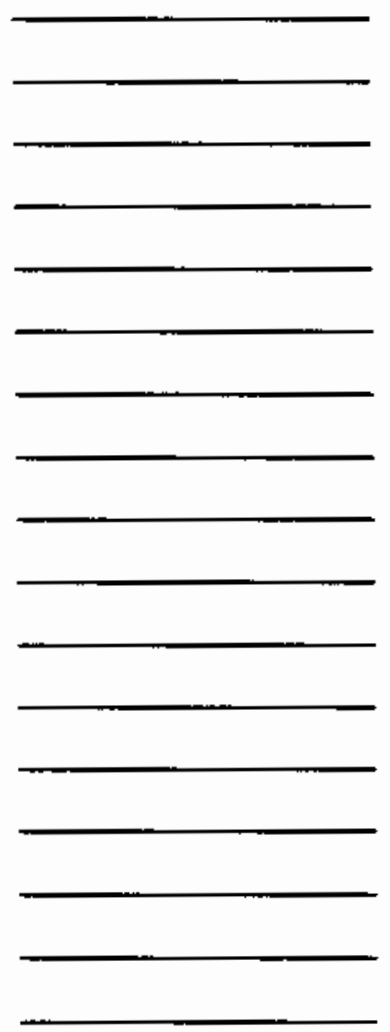

8. Corrected Ingestion $\mathrm{DF}(\mathrm{rem} / \mathrm{yr} / \mathrm{pCi})(\mathrm{b})$

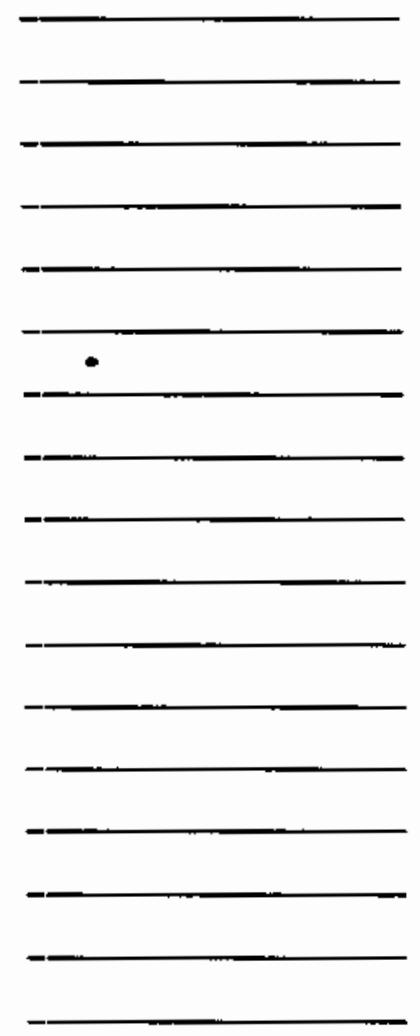

(a) From Form F - Area Correction or Form C - Availability Worksheet. (b) Calculated as Item 5 times Column 7. 


\subsubsection{Task 4.4 - Obtain Agricultural Scenario Dose Estimates}

Apply the Dose Calculation Worksheet to obtain the dose estimates.

Procedure 4.4.1 Application of Stratum Dose Calculation Worksheet to Agricultural Scenario

The radionuclide names, source terms, and standard derivations should be entered on Form $D$, the Stratum Dose Calculation Worksheet (Figure 5.8), from Form B, the Source Term Worksheet (Figure 5.5). The scenario dose factors should be entered from Form $G$, the Depth Correction Worksheet (Figure 5.11). For the special case of contaminated surface soil, the dose factors may be obtained directly from Form $G$, the Availability Correction Worksheet (Figure 5.7). The total estimated dose can be obtained on Form $D$, the Stratum Dose Calculation Worksheet (Figure 5.8), as the sum of the entries in Column 8 i Item 11 on that worksheet must be calculated using Procedure 3.2.2.

\subsection{ACTIVITY 5 - RESOURCE RECYCLE CALCULATION}

The two tasks required to perform the calculation of the dose estimates to the individual recycling contaminated metals taken from the site are illustrated in Figure 5.13. The procedures for implementing these tasks are listed.in Table 5.8.

\subsubsection{Task 5.1 - Apply Mass Correction to Radionuclide Dose Factors}

The dose factors derived in Section 2 of this report are presented in terms of $\mathrm{rem} / \mathrm{pCi}$, where the activity is implicitly assumed to be distributed throughout $200 \mathrm{Mg}$ (200 metric tons) of contaminated metal. If the quantity of material estimated to be recoverable is other than $200 \mathrm{Mg}$, a correction

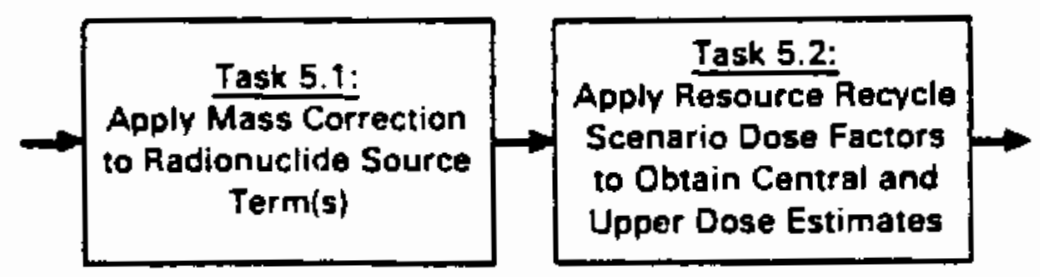

FIGURE 5.13. Tasks Required to Perform Activity 5 Resource Recycle Scenario Calculation 
IABLE 5.8. Procedures Required for Activity 5, Tasks $5.1-5.2$

Task 5.1 Apply Mass Correction to Radionuclide Dose Factors

5.1.1 Application of Mass Correction Worksheet

Task 5.2 Apply Resource Recycle Dose Factors

5.2.1 Application of Stratum Dose Calculation Worksheet to Resource Recycle Scenario

(3.2.2) Calculation of Variance of Estimated Dose

must be made to the dose factors, before the doses can be calculated, using Form $\mathrm{H}$, the Mass Correction Worksheet (Figure 5.14). No upper bound is currently postulated on the recycle mass.

Procedure 5.1.1 Application of Mass Correction Worksheet

The mass correction factor is the ratio of the mass of recyclable metal to $200 \mathrm{Mg}$. Dose Factors input to the worksheet (Figure 5.13) come from Table 2.2.

\subsubsection{Task 5.2 - Obtain Resource Recycle Dose Estimate}

Apply the Stratum Dose Calculation Worksheet (Figure 5.8) to obtain the dose estimates.

Procedure 5.2.1 Application of Stratum Dose Calculation Worksheet to Resource Recycle Scenario

The radionuclide names, source terms, and standard deviations should be entered on Form $D$, the Stratum Dose Calculation Worksheet (Figure 5.8), from Form $B$, the Source Term Worksheet (Figure 5.5). The scenario dose factors should be entered from Form $H$, the Mass Correction Worksheet (Figure 5.14). In the Stratum Dose Calculation Worksheet, Item 11 must be calculated using Procedure 3.2.2.

\subsection{ACTIVITY 6 - SELECTION OF CONTROLLING SCENARIO}

The three tasks necessary to select the controlling scenario between the onsite individual and the offsite recycling worker are shown in Figure 5.15. The procedures used to make the selection are listed in Table 5.9. 


\section{Form H - Mass Correction Worksheet}

1. Facility:

2. Preparer's Name:

3. Date Prepared:

4. Mass of contaminated metal, Mg. 5. Calculate mass correction factor (MCF) as MCF $=$ Item $4 / 200=$

6. Radionuclide 7. Recycle DF $(r e m / v r / p C i)(a)$
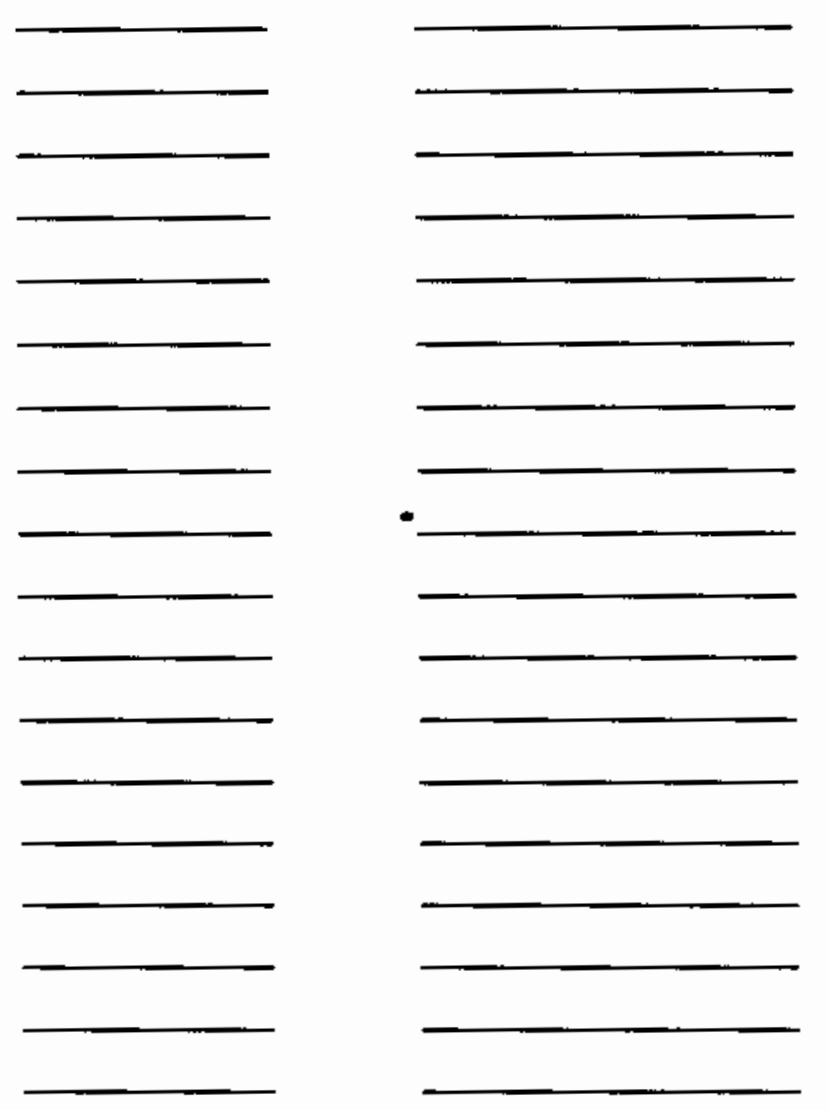


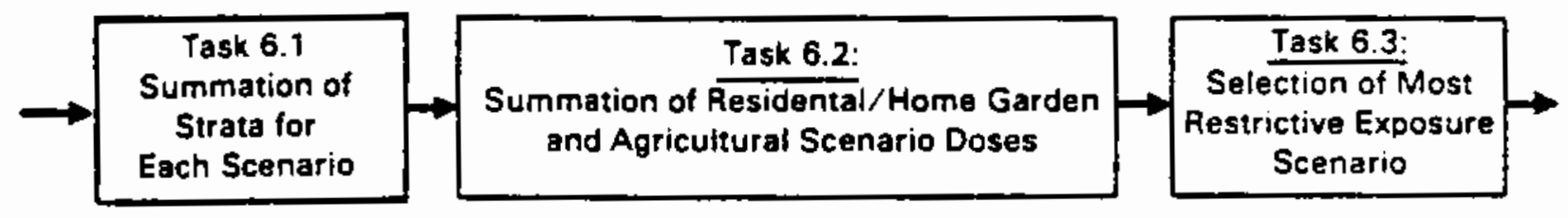

FIGURE 5.15. Tasks Required to Perform Activity 6 -

Selection of Controlling Scenario

TABLE 5.9. Procedures Required for Activity 6, Tasks $6.1-6.3$

Task 6.1 Summation of Strata for Each Scenario

6.1.1 Sumnation of Strata

Task 6.2 Summation of Residential/Home Garden and Agricultural Scenario Doses

6.2.1 Summation of Multiple Scenarios

Task 6.3 Selection of the Most Restrictive Exposure Scenario

6.3.1 Restrictive Scenario Selection

\subsubsection{Task 6.1 - Summation of Strata for Each Scenario}

The total estimated dose, and its variance, for each scenario are computed using Procedure 6.1.1. This procedure shall be used separately for each of the three scenarios being used.

\section{Procedure 6.1.1 Summation of Strata}

Apply Form I, the Final ARCL Worksheet (Figure 5.16), for each of the scenarios employed. The total dose per stratum and the variance of the total dose per stratum came from Items $8 \mathrm{a}$ and 11 of Fom $D$, the Stratum Dose Calculation Worksheet (Figure 5.8), for each stratum.

Items 7 and 8 of the Final ARCL Worksheet need not be filled out at this time unless the UCL on the dose is desired for each individuat scenario. 


\section{Form I - Final ARCL Worksheet}

1. Facility/Scenario:

2. Preparer's Name:

3. Date Prepared:

\section{4.: Stratum or \\ - Scenario Considered (a)}
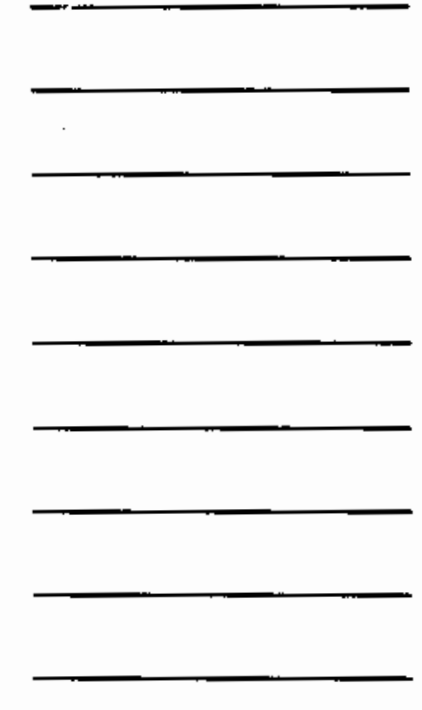

\section{(TOTALS)}

7. (6a) $1 / 2=S D\left[\theta_{S}(t)\right]=$

8. $5 a+z_{1-\alpha}^{(d)} * 7=$

\section{Total Dose per Stratum or Sce- nario (rem/yr) (b)}
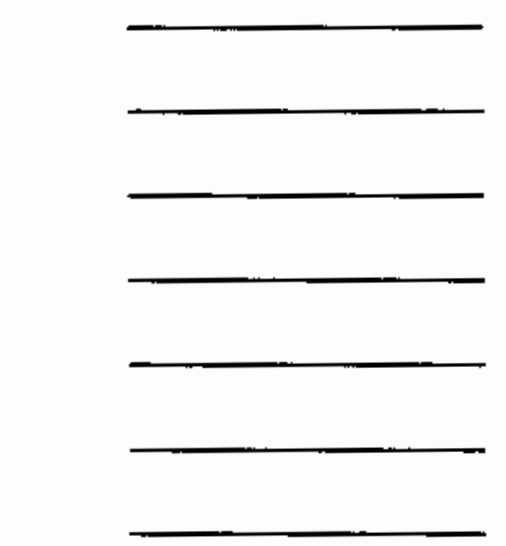

$5 \mathrm{a}=$

$6 \mathbf{a}$
6. Variance of the Dose (c) (rem/yr) ${ }^{2}$

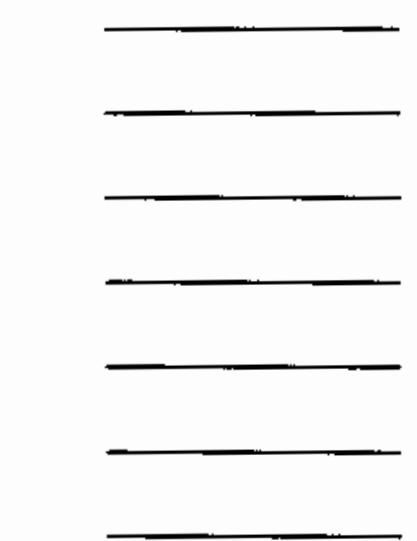

\footnotetext{
(a) Note: Forms A, B, C, and D are completed for each Stratum considered.

(b) From Item Bb in Form D, for each Stratum considered.

(c) From Item 11 in Form D, for each Stratum considered.

(d) Obtained from TabTe 5.5.

.

$\therefore$ FIGURE 5.16. Form I - Final ARCL Worksheet - Summed Over A]1 Strata
} 


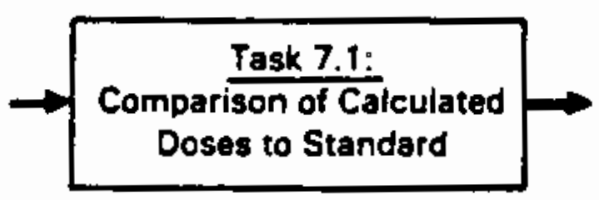

FIGURE 5.17. Task Required to Perform Activity 7 - Comparison of Calculated Doses to Standard

Timit, decommissioning activities may begin. If the UCL dose is greater than the limit, remedial actions before decommissioning are indicated. Document the result. 


\subsection{REFERENCES}

Adams, J. A., P. W. Griffin, M. C. Hughes and D. K. Tyler, 1984. Hanford 100 Area Long-Range Decommissioning Plan. UNI-2533, UNC Nuclear Industries, Inc., Richland, Washington.

Code11, R. B. 1983. "Transport of Radionuclides in Ground Water." In Radiological Assessment, J. E. Till and H. R. Meyer, eds, NUREG/CR-3332, U.S. Nuclear Regulatory Commission, Washington, D.C.

Dorian, J. J., and V. R. Richards. 1978. Radiological Characterization of the Retired 100 Areas. UNI-946, United Nuclear Industries, Richland, Washington.

Enge 1, R. L., J. Greenborg and M. M. Hendrickson. 1966. ISOSHLD - A Computer Code for General Purpose I sotope Shielding Analysis. BNWL-236, Pacific Northwest Laboratory, Richland, Washington.

Federa] Register, Vol. 46, No. 27. 11666-11668 (February 10, 1981). Proposed Rules: Nuclear Regulatory Commission, 10 CFR Parts 30, 40, 50, 70 and 72, "Decomissioning Criteria for Nuclear Facilities; Notice of Availability of Draft Environmental Impact Statement."

Harmon, K. M., and J. C. King. 1975. Resource Book-Decommissioning of Contaminated Facilities at Hanford. PNL-MA-588, Pacific Northwest Laboratory, Richland, Washington.

International Commission on Radiological Protection (ICRP). 1977. "ICRP Publication 26, Recommendations of the International Commission on Radiological Protection." Annals of the ICRP, Vol. 1, No.3. Pergamon Press, oxford.

International Commission on Radiological Protection (ICRP). 1979a. "ICRP Publication 30, Part 1, Limits for Intakes of Radionuclides by Workers." Annals of the ICRP, Vol. 2, No.3/4. Pergamon Press, Oxford.

International Commission on Radiological Protection (ICRP). 1979b. "ICRP Publication 30, Supplement to Part 1, Limits for Intakes of Radionuclides by Workers." Annals of the ICRP, Vol. 3, No.1-4. Pergamon Press, 0xford.

International Commission on Radiological Protection (ICRP). 1980. "ICRP Publication 30, Part 2, Limits for Intakes of Radionuclides by Workers." Annals of the ICRP, Vol. 4, No.3/4. Pergamon Press, 0xford.

International Commission on Radiological Protection (ICRP). 1981. "ICRP Publication 30, Part 3 Including Addendum to Parts 1 and 2, Limits for Intakes of Radionuclides by Workers." Annals of the 1CRP, Vol. 6, No.2/3. Pergamon Press, 0xford. 
International Commission on Radiological Protection (ICRP). 1982a. "ICRP Publication 30, Supplement A to Part 3, Limits for Intakes of Radionuclides by Workers." Annals of the ICRP, Vol. 6, No.2/3. Pergamon Press, 0xford.

International Commission on Radiological Protection (ICRP). 1982b. "ICRP Publication 30, Supplement B to Part 3 Including Addendum to the Supplements of Parts 1 and 2, Limits for Intakes of Radionuclides by Workers." Annals of the ICRP, Vol. 6, No.2/3. Pergamon Press, Oxford.

International Commission on Radiological Protection (ICRP). 1986. "ICRP Publication 48, The Metabolism of Plutonium and Related Elements." Annals of the ICRP, Vol. 16, No.2/3. Pergamon Press, Oxford.

Kennedy, W. E., Jr., and B. A. Napier. 1983a. Al lowable Residual Contamination Levels for Decommissioning the 115-F and 117-F Facilities at the Hanford 5ite. PNL-4704, UNI-2499, Pacific Northwest Laboratory, Richland, Washington.

Kennedy, W. E., Jr., and B. A. Napier. 1983b. Allowable Residual Contamination Levels for Decomissioning Facilities in the 100 Areas of the Hanford Site. PNL-4722, UNI-2522, Pacific Northwest Laboratory, Richland, Washington.

Kennedy, W. E., Jr., L. L. Cadwell and D. H. McKenzie. 1985. "Biotic Transport of Radionuclides from a Low-Level Radioactive Waste Site." Health Physics, Vol. 49(1):11-24.

Kennedy, W. E., Jr., R. A. Peloquin, B. A. Napier and S. M. Neuder. 1986. Intruder Dose Pathway Analys is for the Onsite Disposal of Radioactive Wastes: Supplements to the ONSITE/MAXI1 Computer Program, NUREG/CR-3620, Pacific Northwest Laboratory, Richland, Washington.

Kirkham, R. R., and G. W. Gee. 1984. "Measurements of Unsaturated Flow Below the Root Zone at an Arid Site." In Proceedings of the National Water Well Association Conference on Characterization and Monitoring of the Vadose Zone. National Water Wel1 Association, Las Vegas, Nevada. (PNL-SA11629)

Konzek, G. J., J. D. Ludwick, H. E. Kennedy, Jr., and R. I. Smith. 1981. Technology, Safety and Costs of Decommissioning Reference Nuclear Research and Test Reactors. NUREG/CR-1756, U.S. Nuclear Regulatory Commission, Washington, D.C.

Mackenzie, D. R., J. F. Smalley, C. R. Kempf, and R. E. Barletta. 1985. Evaluation of the Radioactive Inventory In, and Estimation of Isotopic Release From, the Waste in Eight Trenches at the Sheffield Low-Level Waste Burial Site, NUREG/CR-3865, Brookhaven National Laboratory, Upton, New York. 
McCormack, W. D., J. V. Ramsdell and B. A. Napier. 1984. Hanford Dose Overview Program: Standardized Methods and Data for Hanford Environmental Dose Calculations. PNL-3777, Rev. 1, Pacific Northwest Laboratory, Richland, Washington.

McKenzie, D. H., L. L. Cadwe11, L. E. Eberhardt, W. E. Kennedy, Jr., R. A. Peloquin and M. A. Simunons. 1982a. Relevance of Biotic Pathways to the Long-Term Requlation of Nuclear Waste Disposal: Topical Report on Reference Western Arid Low-Level Sites. Vol. 2, NUREG/CR-2675, U.S. Nuclear Regulatory Commission, Washington, D.C.

McKenzie, D. H., L. L. Cadwe11, L. E. Eberhardt, W. E. Kennedy, Jr., R. A. Peloquin and M. A. Simmons. 1982b. Relevance of Biotic Pathways to the Long-Term Requlation of Nuclear Waste Disposal: Topical Report on Reference Western Arid Low-Level Sites. Vol. 3, NUREG/CR-2675, U.S. Nuclear Regulatory Commission, Washington, D.C.

Mueller, M. A., W. E. Kennedy, Jr., and J. K. Soldat. 1981. Review of Soil Contamination Guidance. PNL-3866, Pacific Northwest Laboratory, Richland, Washington.

Napier, B. A., R. L. Roswel1, W. E. Kennedy, Jr., and D. L. Strenge, 1980. ARRRG and FOOD - Computer Programs for Calculating Radiation Dose to Man from Radionuclides in the Environment. PNL-3180, Pacific Northwest Laboratory, Richland, Washington.

Napier, B. A. 1982. A Method for Determining "Allowable Residual Contamination Levels" of Radionuclide Mixtures in Soil. PNL-3852, Pacific Northwest Laboratory, Richland, Washington.

Napier, B. A., R. A. Peloquin, W. E. Kennedy, Jr., and S. M. Neuder. 1984. Intruder Dose Pathway Analysis for the Onsite Disposal of Radioactive Wastes: The ONSITE/MAXI Computer Program. NUREG/CR-3620 (PNL-4054), Pacific Northwest Laboratory, Richland, Washington.

Napier, B. A., R. A. Peloquin, D. L. Strenge and J. V. Ramsde11. 1988. GENII - The Hanford Environmental Radiation Dosimetry Software System. Vols. 1-3, PNL-6584, Pacific Northwest Laboratory, Richland, Washington. In press.

Oak, H. D., G. M. Holter, W. E. Kennedy, Jr., and G. J. Konzek. 1980. Technology, Safety and Costs of Decommissioning a Reference Boiling-Water Reactor Power Station. Vol. 1 and 2, NUREG/CR-0672, U.S. Nuclear Regulatory Commission, Washington, D.C.

O'Donnell, F. R., S. J. Cotter, D. C. Kocher, E. L. Etnier and A. P. Watson. 1978. Potential Radiation Dose to Man from Recycle of Metals Reclaimed from a Decommissioned Nuclear Power Plant. NUREG/CR-0134, U.S. Nuclear Regulatory Commission, Washington, D.C. 
Oztunali, 0. I., and G. W. Roles. 1986. Update of Part 61 - Impacts Analys is Methodology, NUREG/CR-4370, Envirosphere Company, New York, New York.

Piepel, G. F. 1986. Sampling and Sample Size Considerations for Inventory Estimation and ARCL Remedial Action Testing, Pacific Northwest Laboratory, Richland, Washington. Letter report from R. G. Schreckhise (PNL) to J. A. Adams (UNC Nuclear Industries), dated October 15, 1986.

Prater, L. S., J. T. Rieger, C. S. Cline, E. J. Jensen, T. L. Lijkala, K. R. Oster and P. A. Eddy. 1984. Ground-Water Surveillance at the Hanford Site for CY 1983. PNL-5041, Pacific Northwest Laboratory, Richland, Washington.

Reisenauer, A. E. 1979. Variable Thickness Transient Groundwater Flow Model. PNL-3160-1,2,3, Pacific Northwest Laboratory, Richland, Washington.

Schneider, J. K., and C. E. Jenkins. 1977. Technology, Safety, and Costs of Decomissioning a Reference Nuclear Fuel Reprocessing Plant. NUREG-0278, U.S. Nuclear Regulatory Commission, Washington, D.C.

Simmons, G. L. 1967. ISOSHLD II Code Revision to Include Calculation of Dose Rates from Shielded Bremstrahlung Sources. BNWL-236, Supplement 1 , Pacific Northwest Laboratory, Richland, Washington.

Smith, R. I., G. J. Konzek, and W. E. Kennedy, Jr. 1978. Technology. Safety, and Costs of Decommissioning a Reference Pressurized Water Reactor Power Station. NUREG/CR-0130, U.S. Nuclear Regulatory Commission, Washington, D.C.

Staley, G. B., G. P. Turi and D. L. Schreiber. 1979. "Radionuclide Migration from Low-Level Waste: A Generic Overview." In Management of Low-Level Radioactive Waste, Vol. 2, eds. M. W. Carter, A. A. Moghissi and B. Kotn.

U.S. Atomic Energy Commission (AEC). 1974. Termination of Operating Licenses for Nuclear Reactors. Regulatory Guide 1.86, Directorate of Regulatory Standards, Washington, D.C.

U.S. Code of Federal Regulations (CFR). Title 40, Part 190, "Environmental Protection Standards for Nuclear Power Operations."

U.S. Code of Federal Requlations (CFR). Title 40, 192, "Environmental Protection Standards for Uranium Mill Tailings."

U.S. Nuclear Regulatory Commission (NRC). 1976. Guidelines for Decontamination of Facilities and Equipment Prior to Release for Unrestricted Use of Termination of Licenses for By-Product, Source, or Special Nuclear Material. RS2-1131, U.W. Nuclear Regulatory Commission, Washington, D.C. 
U.S. Nuclear Regulatory Commission (NRC). 1980. Draft Environmental Impact Statement Concerning Proposed Rulemaking Exemption from Licensing Requirements for Smelted Alloys Containing Residual Technetium-99 and LowEnriched Uranium. NUREG-0512, U.S. Nuclear Regulatory Commission, Washington, D.C.

U.S. Nuclear Regulatory Commission (NRC). 1981. Draft Environmental Impact Statement on 10 CFR Part 61 . "Licensing Requirements for Land Disposal of Radioactive Waste." Vol. 1-4, NUREG-0782, U.S. Nuclear Regulatory Commission, Washington, D.C.

Washington State University. 1970. Alfalfa Irrigation. E.M 3468, Cooperative Extension Service, Pullman, Washington. 


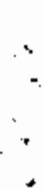


APPENDIX A

EXAMPLE CALCULATION 
APPENDIX A

\section{EXAMPLE CALCULATION}

As an example application of the Allowable Residual Contamination Level (ARCL) technique described in this report, the complete calculation of a 90th percentile upper confidence limit dose for an actual facility is presented in Table A.5 and A.6. The 115-D/DR Gas Recirculation Building, located in the 100-D Area of the Hanford Site, was used as the example facility. The 115$D / D R$ Building was connected to the $D$ and $D R$ reactors by tunnels and was adjacent to the 117-D Filter Building. The inventory of radiocontaminants present in the 117-D Building were added to the inventory values used for the 115-D/DR Building which complicated the ARCL calculations. A portion of the contamination in the 115-D/DR Building was located inside of large-diameter pipes, which necessitated the need to examine the Recycle scenario. This example calculation includes the following scenarios:

- Residential/Home Garden--for the 115-D/DR Building itself;

- Agricultural--for the radionuclides in the 115-D/DR Building not included in the Residential/Home Garden scenario above along with the radiocontaminants in the 117-D Building; and

- Resource Recycle--for the radionuclides in the pipes.

The available sampling data are sumarized in Table A.1 for the 115$D / D R$ Bujlding, excluding the data for the associated piping, which are presented in Tables A.2 and A.3. Table A.4 summarizes the data for the 117-D Building. Evaluation of the data suggested that the 115-D/DR Building and its surroundings should be separated into the following strata:

1. main floor and basement of the 115-D/DR Building, excluding a portion of Dry Room \#1;

2. the excluded portion of Dryer Room $\# 1$ in the 115-D/DR Building;

3. 115-D Tunnel; 
4. 115-DR Tunnel;

5. 117-D Building's Inlet Duct, A Filter Cel1, and A Outlet Seal Pit;

6. 117-D Building's Outlet Duct, A Inlet Seal Pit, B Inlet Seal Pit, B Filter Cell, and B Outlet Seal Pit; and

7. Pipes in the 115-D/DR Building.

Summary statistics for each of these strata were prepared using the SAS(a) standard computer package and are presented in copies of Form A, the Summary Statistics Table (Figure 5.3), for each stratum. For each stratum, the measured "gross $\alpha$ " values were treated as if they represented ${ }^{239} \mathrm{Pu}$.

Calculations for the Agricultural scenario were performed for each of the strata with the exception of the pipes. For the area of highest dose potential (i.e., a section of 115-D/DR Dryer Room \#1 and surrounding material) the calculations for the Residential/Home Garden scenario are shown. For the pipes, the Resource Recycle scenario calculations are presented.

Results for each stratum were summed for the Agricultural scenario on Form D. The results were also summed for the two strata involved in the Residential/Home Garden scenario. These two values were then added together and compared to the Resource Recycle scenario. It was apparent that the Residential/Home Garden scenario dominated the final answer, and that it in turn was largely controlled by the small area of Dryer Room \#1, which sampling indicated had a relatively high concentration of ${ }^{90} \mathrm{Sr}$.

Some of the assumptions made and observations developed during the calculations are listed in the following:

- The strata were formed basically considering ${ }^{90} \mathrm{Sr}$ concentrations since it was the dominant radionuclide. In some cases, further stratification seemed appropriate; however, it was not implemented because the amount of data that would be assigned to the additional strata would not be sufficient.

(a) SAS Institute Incorporated, Cary, North Carolina. 
- Post-stratification (i.e., stratifying the data after the samples are collected instead of defining the strata before the sampling is conducted) can be dangerous when there are insufficient data to support it. The data were post-stratified in the example since the samples were collected prior to the development of the statistical techniques outlined here. Besides, post-stratification seemed reasonable to do since there was one dominant radionuclide, and most of the projected dose came from a 37-sq-ft hot spot in Dryer Room \#1 of the 115-D/DR Building. Pre-sampling efforts should be conducted to define the appropriate strata to be sampled in more detail.

- As indicated by footnotes in the worksheets, the data were often insufficient for computing many of the variances and covariances. Even where they could be computed, many times it was with fewer than five observations. The general solution is to collect additional samples and make sufficient analyses for each radionuclides so as to have at least five values per radionuclide per stratum. Beyond this, input from sample size tables and formulas should be considered.

- Care must be taken in estimating values for missing data or statistical sumaries. This is especially true for situations where the resulting calculations are near the prescribed limit. 


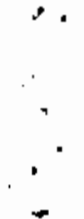

$-$

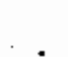




\section{TABLES A.1 - A.7}

SAMPLING DATA FOR 115 D/DR and 117-D BUILDINGS 
IABLE A.1. Sampling Data for the 115-D/DR Gas Recirculation Building (pCi/g)

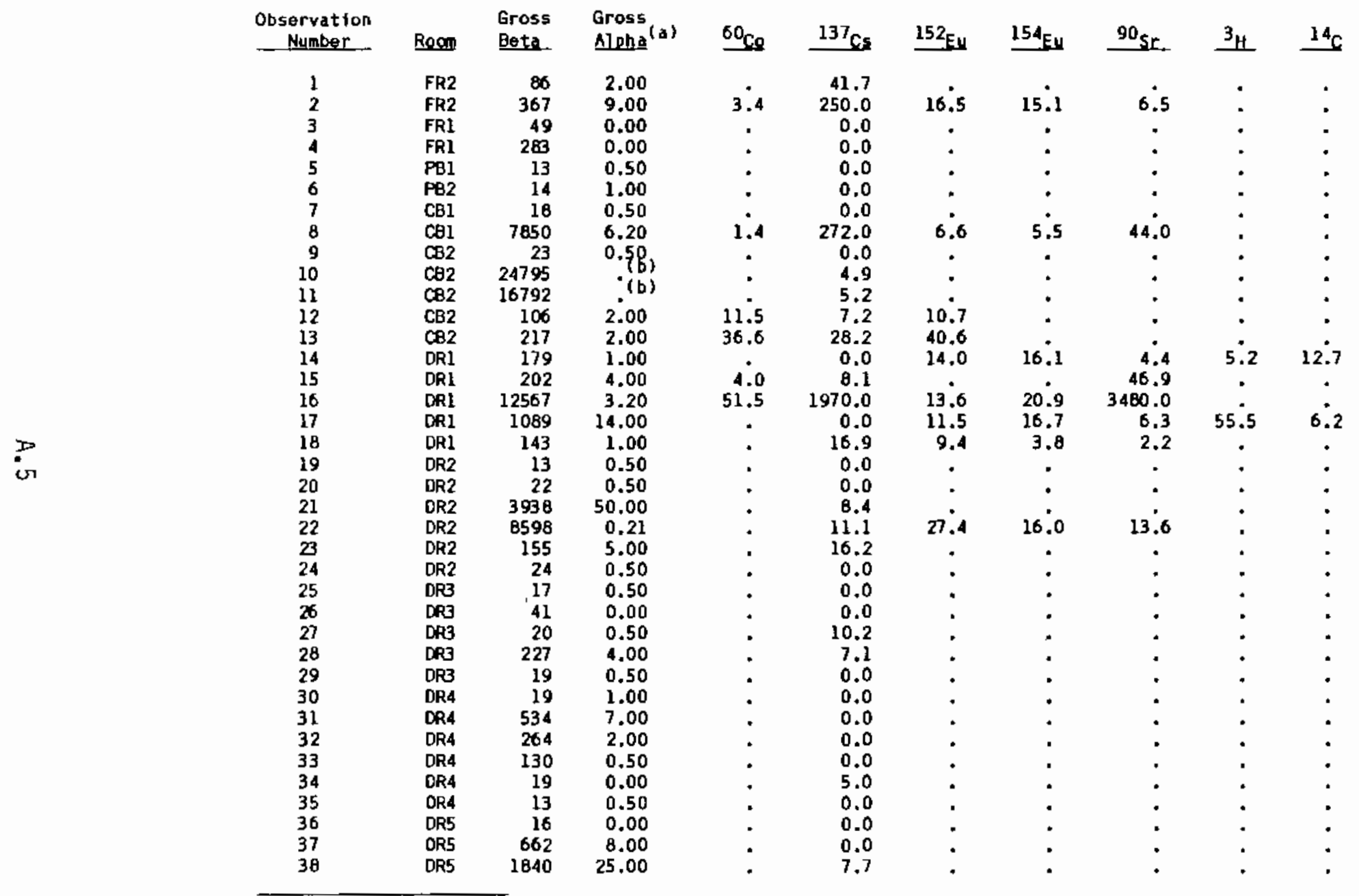

(a) The gross alpha values were treated as ${ }^{239}$ Pu values.

(b) Due to the type of method used, scme gross alpha measurements vere affected by the presence of beta/gammaemitting radionuclides. Most abnormally high alpha measurements vere resolved by additlonal measurements using another method. Hovever, this was not done for observations 20 and 11 (which had gross alpha values of 240 and 166 , respectively). Therefore, following Uic's reccmmendations, observations 10 and 11 were assumed to be outllers and vere treated as missing observations. 


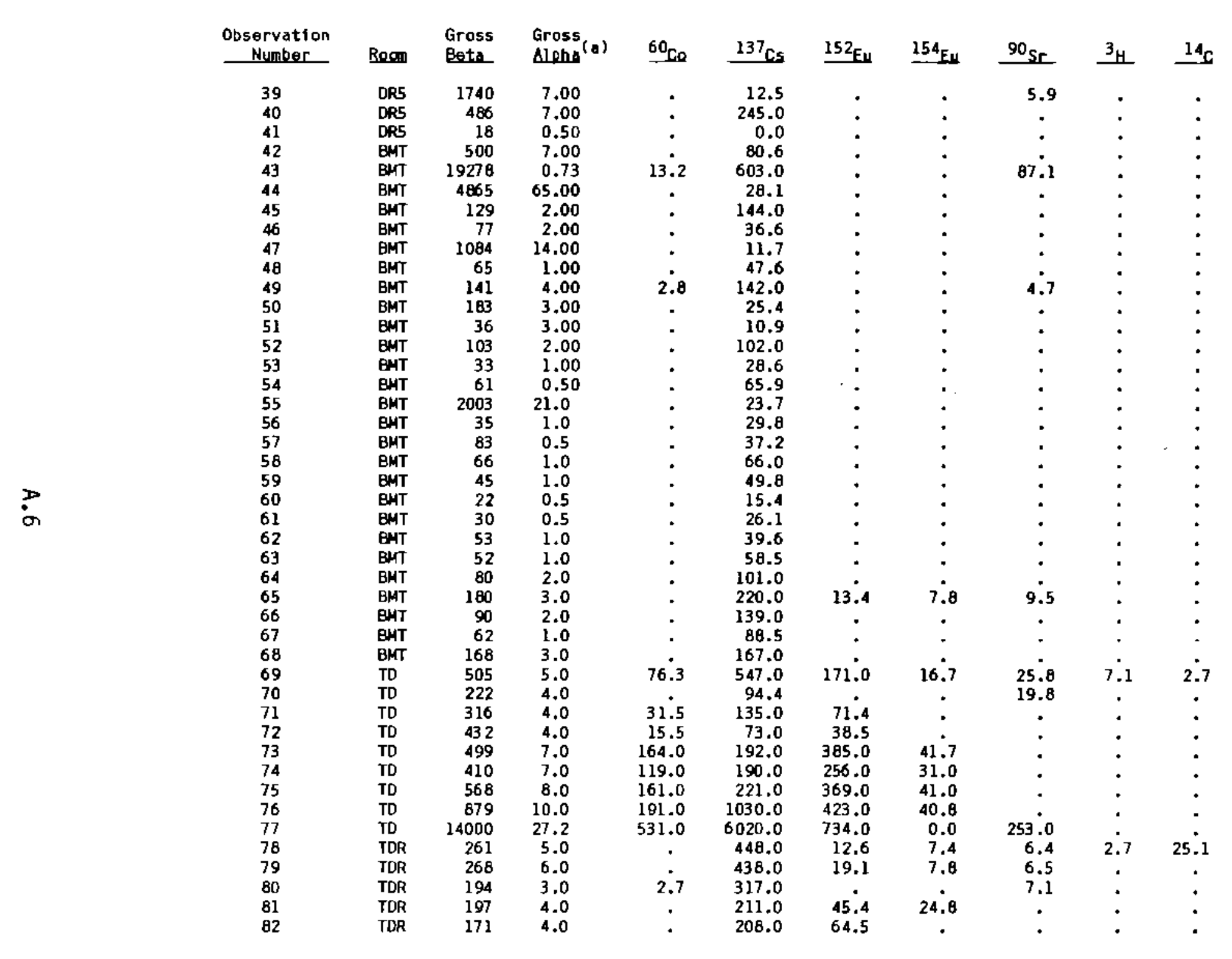

(a) The gross alpha values vere treated as ${ }^{239} \mathrm{Pu}$ values. 
IABLE A.2. Sampling Data for the 117-D Filter Building ( $\mathrm{pCi} / \mathrm{g}$ )

Observation

\begin{tabular}{|c|c|c|c|c|c|c|c|c|}
\hline Number & Room & $239 \mathrm{pu}$ & $3 \mathrm{H}$ & $14 \mathrm{C}$ & $60 \mathrm{CO}_{0}$ & $90 \mathrm{sr}$ & $137 \mathrm{Cs}$ & $152 \mathrm{Eu}$ \\
\hline 1 & ID & 0 & 118 & 216 & - & 217 & 682 & 31 \\
\hline 2 & ID & 9 & - & - & - & - & 241 & - \\
\hline 3 & ID & 10 & - & - & - & - & 329 & - \\
\hline 4 & ID & 7 & - & - & - & - & 214 & - \\
\hline 5 & ID & 7 & - & - & - & - & 209 & - \\
\hline 6 & ID & 10 & - & - & - & - & 330 & - \\
\hline 7 & ID & 7 & - & - & - & - & 156 & - \\
\hline 8 & ID & 6 & - & - & - & - & 39 & - \\
\hline 9 & ID & 7 & - & - & - & - & 109 & - \\
\hline 10 & ID & 5 & - & - & - & - & 384 & - \\
\hline 11 & $O D$ & 38 & - & - & - & - & - & - \\
\hline 12 & 00 & 32 & - & - & - & - & - & - \\
\hline 13 & 00 & 39 & - & - & - & - & 29 & - \\
\hline 14 & $0 \mathrm{D}$ & 36 & - & - & - & - & - & - \\
\hline 15 & $O D$ & 19 & - & - & - & - & - & - \\
\hline 16 & 00 & 49 & - & - & - & - & 34 & - \\
\hline 17 & $0 D$ & 47 & - & - & - & - & - & \\
\hline 18 & 00 & 15 & - & - & - & - & - & - \\
\hline 19 & $0 D$ & 38 & 23 & 25 & - & 6 & 36 & - \\
\hline 20 & $O D$ & 23 & - & - & - & - & 34 & - \\
\hline 21 & AISP & 3 & - & - & - & - & 101 & - \\
\hline 22 & AISP & 5 & 17 & 29 & 17 & 16 & 174 & - \\
\hline 23 & BSIP & 5 & - & - & - & 8 & 409 & - \\
\hline 24 & BSIP & 8 & 9 & 24 & - & 2 & 100 & _- \\
\hline 25 & AFC & 12 & - & - & 44 & 396 & 761 & - \\
\hline 26 & AFC & 18 & - & - & 175 & 739 & 1410 & - \\
\hline 27 & AFC & 8 & 683 & 573 & 180 & 561 & 1070 & 64 \\
\hline 28 & AOSP & 3 & 8 & 20 & 32 & 136 & 23 & \\
\hline 29 & AOSP & 4 & - & - & - & - & - & - \\
\hline 30 & $B F C$ & 10 & - & - & - & - & 442 & - \\
\hline 31 & $\mathrm{BFC}$ & 12 & - & - & - & - & 381 & - \\
\hline 32 & $B F C$ & 15 & 96 & 132 & - & 3 & 1750 & - \\
\hline 33 & $\mathrm{BFC}$ & 35 & - & - & 454 & 55 & 3230 & - \\
\hline 34 & BOSP & 1 & - & - & - & - & & \\
\hline 35 & BOSP & 3 & 9 & 25 & - & 10 & 17 & \\
\hline
\end{tabular}


IABLE A.3. Sampling Data for the Pipes in the $115-0 / D R$ Building (pCi/15.5 $\mathrm{cm}^{2}$ )

\begin{tabular}{|c|c|c|c|c|c|c|c|c|c|c|}
\hline $\begin{array}{l}\text { Observation } \\
\text { Number } \\
\end{array}$ & Room & $\begin{array}{l}\text { Sample } \\
\text { Number }\end{array}$ & ${ }^{3} \mathrm{H}$ & ${ }^{14} \mathrm{C}$ & ${ }^{90} \mathrm{sr}$ & ${ }^{60} \mathrm{Co}$ & ${ }^{137} \mathrm{C}_{5}$ & $152_{E u}$ & ${ }^{154} \mathrm{EU}_{4}$ & Alpha \\
\hline 1 & D & 1 & . & . & 390 & . & 51500 & . & . & . \\
\hline 2 & D & 2 & 94.7 & 36.6 & . & 7218.0 & 8060 & . & . & 651 \\
\hline 3 & D & 3 & . & . & . & 7846.0 & 19500 & 684 & 549 & 691 \\
\hline 4 & D & 4 & . & . & . & 1809.0 & 17700 & 682 & 399 & . \\
\hline 5 & D & 5 & . & . & . & 72.2 & 2210 & 495 & 201 & 116 \\
\hline 6 & D & 6 & . & . & . & 71.8 & 33100 & 346 & 202 & 119 \\
\hline 7 & D & 7 & . & . & 155.0 & . & 56000 & 498 & 203 & . \\
\hline 8 & D & 8 & . & . & 54.8 & . & 57200 & 344 & 1287 & . \\
\hline 9 & D & 9 & . & . & 101.0 & . & 69000 & 345 & 201 & . \\
\hline 10 & D & 10 & . & . & 46.8 & . & 48000 & 1116 & 401 & . \\
\hline 11 & DR & 1 & . & . & 197.0 & . & 35700 & 504 & 202 & . \\
\hline 12 & $\mathrm{DR}$ & 2 & 115.0 & 4.5 & . & . & 82000 & 706 & 818 & 123 \\
\hline 13 & $D R$ & 3 & • & . & 170.0 & 72.2 & 89100 & 345 & 202 & . \\
\hline 14 & DR & 4 & 300.0 & 6.4 & 167.0 & . & 69900 & 344 & 200 & 120 \\
\hline 15 & $D R$ & 5 & . & . & 306.0 & . & 96500 & 344 & 399 & . \\
\hline 16 & DR & 6 & . & . & 286.0 & 72.0 & 60500 & 345 & 201 & . \\
\hline 17 & DR & 7 & . & . & . & 72.1 & 22800 & 346 & 203 & 112 \\
\hline 18 & $\mathrm{DR}$ & 8 & . & . & . & 71.8 & 22100 & 345 & 201 & 122 \\
\hline 19 & $D R$ & 9 & 13300.0 & 585.0 & . & 71.9 & 15700 & 345 & 201 & 115 \\
\hline 20 & DR & 10 & 6515.0 & 315.0 &. & 898.0 & 20700 & 984 & 401 & 150 \\
\hline
\end{tabular}


TABLE A.4. Sampling Data for the Pipes in the 115-D/DR Building Converted to $\mathrm{pCi} / \mathrm{g}$ (values in Table $\mathrm{A} .3$ divided by $155 \mathrm{~g} / \mathrm{cm}^{2}$ )

\begin{tabular}{|c|c|c|c|c|c|c|c|c|c|c|}
\hline $\begin{array}{c}\text { Observation } \\
\text { Number }\end{array}$ & Roan & $\begin{array}{l}\text { Sample } \\
\text { Number }\end{array}$ & ${ }^{3} \mathrm{H}$ & ${ }^{14} c$ & ${ }^{90} \mathrm{Sr}$ & ${ }^{60} \mathrm{Co}$ & ${ }^{137} C_{5}$ & $152_{E U}$ & $154_{\mathrm{EU}}$ & Alpha \\
\hline 1 & D & 1 & . & . & 2.51 & . & 332. & . & . & . \\
\hline 2 & D & 2 & 0.611 & 0.236 & . & 46. & 52.0 & . & . & 4.20 \\
\hline 3 & D & 3 & • & • & . & 50.6 & 126. & 4.41 & 3.54 & 4.46 \\
\hline 4 & D & 4 & . & . & . & 11.7 & 114. & 4.40 & 2.57 & . \\
\hline 5 & D & 5 & . & . & . & 0.466 & 14.3 & 3.19 & 1.30 & 0.748 \\
\hline 6 & D & 6 & . & . & . & 0.463 & 214 & 2.23 & 1.30 & 0.768 \\
\hline 7 & D & 7 & . & . & 1.00 & . & 361. & 3.21 & 1.31 & $\cdot$ \\
\hline 8 & D & 8 & . & . & 0.354 & . & 369 & 2.22 & 8.30 & . \\
\hline 9 & D & 9 & . & . & 0.652 & . & 445 & 2.23 & 1.30 & . \\
\hline 10 & D & 10 & . & . & 0.302 & . & 310. & 7.20 & 2.59 & . \\
\hline 11 & DR & 1 & . & . & 1.27 & . & 553. & 3.25 & 1.30 & . \\
\hline 12 & DR & 2 & 0.742 & 0.0290 & • & . & 529. & 4.55 & 5.28 & 0.794 \\
\hline 13 & DR & 3 & . & • & 1.10 & 0.466 & 575. & 2.23 & 1.30 & . \\
\hline 14 & DR & 4 & 1.94 & 0.0413 & 1.08 & . & 451. & 2.22 & 1.29 & 0.774 \\
\hline 15 & OR & 5 & • & • & 1.97 & . & 623. & 2.22 & 2.57 & . \\
\hline 16 & OR & 6 & . & . & 1.85 & 0.465 & 390. & 2.23 & 1.30 & . \\
\hline 17 & $D R$ & 7 & . & . & • & 0.465 & 147. & 2.23 & 1.31 & 0.723 \\
\hline 18 & OR & 8 & • & • & . & 0.463 & 143. & 2.23 & 1.30 & 0.787 \\
\hline 19 & DR & 9 & 85.8 & 3.77 & . & 0.464 & 101. & 2.23 & 1.30 & 0.742 \\
\hline 20 & DR & 10 & 42.0 & 2.03 & . & 5.794 & 134. & 6.35 & 2.59 & 0.968 \\
\hline
\end{tabular}


$\therefore$ 
SAMPLE ARCL WORKSHEETS FOR 1150/DR and 117-D BUILDINGS

$\cdot$ 
Form A - Sumary Statistics Table - Eatimated Uans, Standard Deviations, and Covariances per Stratul

1. Facility and Stratun: 116 D/DR - Hain Floor and Basenent (Roone FR2, FR1, PB1, PB2, CB1, CB2, DR1, (except seall portion) DR2, DR3, DR4, DR5, and BNT, (See Table A.1 for individual sanple results).

2. Preparer's Hace: G. F. Piepe

\section{Lean 6. S. D}

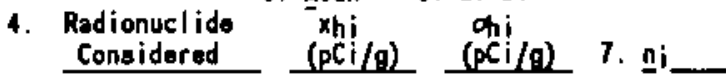

Co-60

Co-137

Eil-152

Eil-154

吕
3. Dato Prepared: $6 / 25 / 80$

8. Nuclide $i(0)$ Auclide $j(a)$

$\mathrm{Co-60}_{\mathrm{C}} \mathrm{Cs-137}$

Co-60

Co-60

${ }_{C 0-60}-\frac{E y-164}{S r-90}$

$\mathrm{Co-80}_{\mathrm{H}-3}$

$\frac{\mathrm{Co}-80}{\mathrm{Co}} \frac{\mathrm{H}}{\mathrm{C}-14}$

Ca-137 $\frac{C-14}{\mathrm{Cu}-152}$

$\frac{C_{a}-137}{C_{a}-137}-\frac{E U-152}{E y-164}$

$\frac{\text { Ca-137 }}{\text { Ca-137 }}-\frac{\text { Eu-164 }}{\text { Sr-90 }}$

$\frac{C_{a}-137}{C_{a}-137} \frac{5 r-96}{h-3}$

$\frac{C_{a-137}}{C_{0-137}} \frac{\mathrm{H}-3}{\mathrm{C}-1 \mathrm{~A}}$

EN-152

${ }_{\mathrm{Eu}}-152 \mathrm{C}$

Eu-152

Eu-152

Ev-154 -

Eu-154

Eu-154

\$r-90

Sr-g

Sh-3

a/ $/ 3 u-239$

a) $P u-239$

Q $/$ Pu-239

a/Pu-239

a) $P u-239$

a) $P$ y-239

taking into accoun other aspects of the data. This ras done to complete this exaaplo and is not recommended as general practice. For $n h i j \leq 2$, use nhij=1 in any computations requiring the vajues. \begin{tabular}{l} 
0. Covariance \\
$\left(\sigma_{\text {oij }}\right)(a)$ \\
\hline
\end{tabular}

11. Nuaber of Samples

for wich both

Muclides are Analyzed

(nhij)
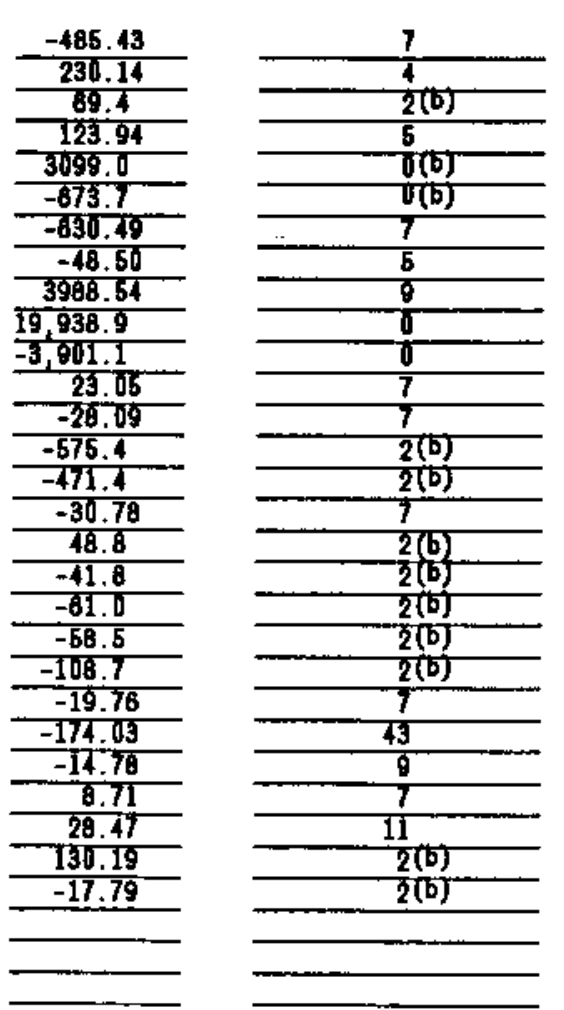


\section{Forn B - Source-Tern Workshoet}

1. Facility/Scenario and Stratun: 115-O/OR - Rosidential-Hone Garden Scenario - Hain Floor and Basenent (excopt anall portion of Dryer Roan (1)

2. Preparer's Nase: G. F. Piepel

3. Date Prepared: $6 / 25 / 88$

4. Stratun Hess (a) (grans): $5.25 \mathrm{E}+8$ (a)

6. Nunber of Years of Decay: $100(t)$

7. Wean Concentration in Stratun.

8. Radionuclide Considered

Co-60

Co-60

Eu-152

Eu-154

Sr-9

$\mathrm{H}-3$

$\mathrm{C}-14$

의 $\mathrm{u}-230$

xhi
(pci/g) (b)

$\frac{10.41}{74.34}$

$\frac{18.68}{11.67}$

$\frac{11.57}{21.01}$

30.35

$\begin{array}{r}9.45 \\ \hline .74\end{array}$

4.74

8. Stratun Concontration

5. D. (b)

\begin{tabular}{c}
$c h i$ \\
$(p c i / g)$ \\
\hline
\end{tabular}

9. Wuber of
Sanples

$\longrightarrow$

in Stratue

in Stratua

18. Source

$$
\text { Thi (d) }
$$

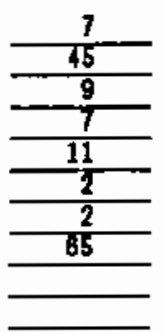

11. 5. D.
Yhi (d)

6. 47E+7 $\quad 2.48 \mathrm{E}+7$

$3.90 \mathrm{E}+8$

8.76E+7

Q.07E+7

$1.10 \mathrm{E}+8$

$1.59 \mathrm{E}+8$

$\frac{4.98 \mathrm{E}+6}{2.4 \mathrm{AE}+\mathrm{E}}$

$\frac{2.46 E+7}{6.46 E+7}$

$1.88 \mathrm{E}+1$

1.12E+7

$4.2 \mathrm{EE}+7$

1.32E+

$\frac{1.71 E+7}{6.94 E+6}$

12. Decayed

Source

Torn

13. Decayed S. D.

$1.24 \mathrm{E}+2$

S.0UE+1

I.2AE+4

$\frac{1.21 E+4}{0.98 E+6}$

$\frac{0.98 E+6}{5.8 E E+5}$

$1.90 \mathrm{E}+7$

$\underline{2.48 E+7}$

$\longrightarrow$

5. $56 \mathrm{E}+1$

9.46E+

$2.2 \mathrm{dE}+3$

$3.88 \mathrm{E}+6$

$\frac{1.88 E+6}{1.085+7}$

$1.89 \mathrm{E}+1$

(a) Strata aro dofined to consist only of contaninated eatorial.

(b) Copy fron Sumary Statistics Table (Table 5.2.1)

(c) Calculato as Iten 4 times Itee 7

(d) S. D. $\left(v_{h i}\right)=\left(\frac{-h_{h i}}{n_{h i}}\right)^{1 / 2}$

(e) Calculate as Itee 10 times o- $\lambda_{i} t$ where $\lambda_{i}=$ decay constant for radionuclide $i$ (fron Tablo 5.2 .3 ) and $t=$ nuaber of yoara of decay

(f) Caleulate as Iten 11 tiues e- $\lambda_{i} t$ where $\lambda_{i}=$ decay conatant for radionuclide $i$ (froe Table 6.2.3) and $t=$ nunber of years of decay (Iten 5) 
1. Facility/Scenario and Stratum: 115 D/OR Residential-Hono Garden Scenario - Hain Floor and Besenent (except anall portion of Dry Roan 1)

2. Preparer's Nano: G. F. Piopol

3. Date Prepared: 6/26/86

B. Unnodified Dose Factors (b)

4. Radionucl ide Considered

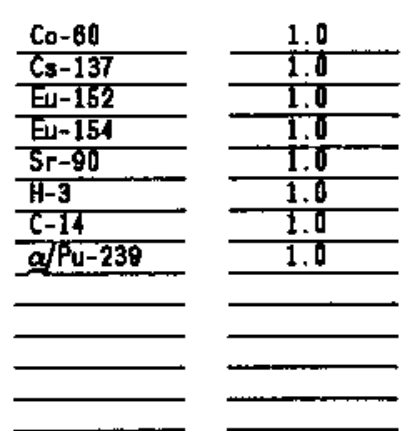
Ba. Inhalation 6 b. Ingestion
(roe/yr per $p C i)$ (rea/yr per $p C i)$

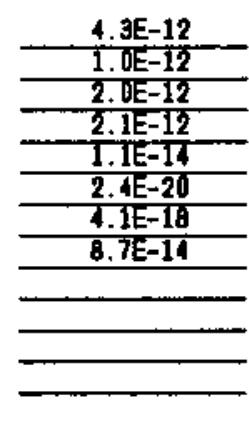

7. Corrected Dose Factors (c) 7a. Inhalation 7b. Ingestion (res/yr per pCi) (rea/yr por $p(i)$

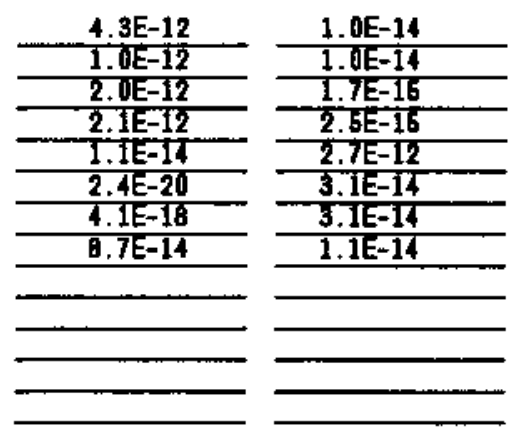

8. Residential/HoweGarden(a) Scenerio Dose Factors (reas yr por pCi)

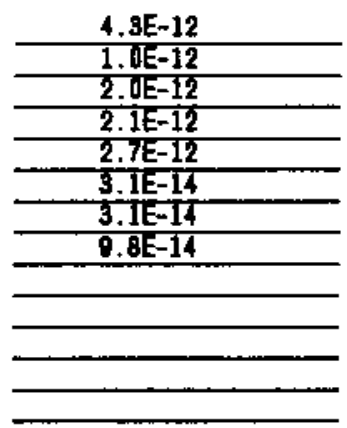

(a) $F=1.0$ for radionuclides not contsined in activated notals $\mathrm{RF}=2 \mathrm{t}$ (corrosion rate $\mathrm{co} / \mathrm{yr}$ )/(thicknoss in $\mathrm{ca}$ ).

(b) From Tablo 2.2.

(c) Calculated as the product of coluna 5 and 8 , by radienuclide.

(d) Complote this coluan only for the Residential/Hone Gorden scenario. The scenario dose factors are calculated as Coluan 7 p plus Coluen $7 b$. 
Form E--Dose Variance [ $\left.\operatorname{Var}\left(\hat{Q}_{h}\right)\right]$ Calculation Horksheet for Stratum $h$

1. Facility and Stratura 115D/DR - Matn floor \& basement (except small portion of Oryer Room \$1)

2. Preparer's Nane.GF Piepeldenttal Home Garden Scenario

2. Preparer's Name:GF Piepel 3. Date Prepared: $6 / 25 / 86$ 4. Stratua Mass (mh):5.25E+6 g 5. Decay Time (t): 100 yr

\begin{tabular}{|c|c|c|c|c|c|c|c|c|c|c|c|}
\hline \multirow{4}{*}{$\left|\begin{array}{l}\frac{6 . *}{\text { Radio }} \\
\text { nucli } \\
\text { de hj }\end{array}\right|$} & & & & \multicolumn{7}{|c|}{ Ahjol } & \multirow{4}{*}{$\frac{10 .}{d_{h j}\left[d_{h k}{ }^{A} h j k\right.}$} \\
\hline & & Radionuc & clide $h^{k}$ : & $\frac{2}{13^{7} c^{2}}$ & $\begin{array}{c}3 \\
152 E \underline{I}\end{array}$ & $\begin{array}{c}4 \\
154 E u \\
\end{array}$ & $\begin{array}{r}\frac{5}{2} \\
90 \mathrm{Sr} \\
\end{array}$ & $\frac{6}{3 \mathrm{H}}$ & $\frac{7}{14 C}$ & $\frac{8}{239 \mathrm{Pu}}$ & \\
\hline & $7^{*}$ & 8. $^{*}$ & $9{ }^{\star} \quad$ Ahk: & $2,3 \mathrm{E}-2$ & $5.2 \mathrm{E}-2$ & $8.5 \mathrm{E}-2$ & $2,4 \mathrm{E}=2$ & $5,6 \mathrm{E}-2$ & $1.2 E=4$ & $2,9 E-5$ & \\
\hline & $\| \mathrm{SO}(\mathrm{d} h \mathrm{hyhj})$ & & $\left.\mathrm{dh}_{\mathrm{j}}\right\rangle \mathrm{dh \textrm {k } :}$ & $1,0 \mathrm{E}-12$ & $2.0 \mathrm{E}-12$ & 2.1E-12 & $2,7 \mathrm{E}-12$ & $3,1 \mathrm{E}-14$ & $3.1 \mathrm{E}-14$ & $9.8 E-14$ & \\
\hline $1.60 \mathrm{Co}$ & $2,4 E-10$ & 1. $3 E-1$ & $4.3 E-12=$ & $\frac{485.43}{7} e^{43} 15$ & $3 \frac{230}{4} e^{\frac{1}{4}} 18$ & $2 \frac{69.4}{2} e^{-21.5}$ & $\frac{123.94}{5}-15.4$ & $\frac{3099}{1} e^{0}-18.6$ & $\frac{673}{1} e^{2}-13$ & $0 \frac{-19.75}{7} e^{6}-13.0$ & $-2.02 E-28$ \\
\hline $2{ }^{37} \mathrm{cs}$ & 8. $5 E-6$ & 2. $3 \mathrm{E}-2$ & $1.0 \mathrm{E}-12$ & & $\frac{-630}{7}-e^{4.99} 7.5$ & $\frac{-48.50}{5} e^{2} 10 \theta$ & $\frac{9988}{9} e^{5-4} 4.70$ & $\frac{19,939}{1} 7.90$ & $\frac{-390}{1} \mathrm{k}^{2 / 2} \cdot 3$ & $2-\frac{174}{43} e^{83} 2,30$ & $-1.01 E-24$ \\
\hline $3.52 \mathrm{Eu}$ & 0 & $5.2 \mathrm{E}-2$ & $2.0 E-12$ & & & $\frac{23.0}{7} \varepsilon-13.7$ & $\frac{-28.89}{7} e^{9} 7.60$ & $\frac{-575}{2} e^{4}-10.8$ & $\frac{-7.71}{2} e^{\frac{4}{2}}-5.2$ & $\frac{-14.78}{9} e^{-5.20}$ & $-9.26 E-26$ \\
\hline $4{ }^{54} \mathrm{Eu}$ & $4.8 E-9$ & 1.5E-2 & $2.1 E-12 \mid$ & & & & $\frac{-90}{7} \cdot e^{8} 10.9$ & $\frac{4 \bar{\theta}, \bar{\theta}}{2} \mathrm{e}^{-14.1}$ & $\frac{-41}{2} e^{8}-8.5$ & $\frac{8.71}{7}=-8.50$ & $-6.81 E-28$ \\
\hline \begin{tabular}{l|l}
5 & $90 \mathrm{Sr}$
\end{tabular} & $1.0 \mathrm{E}-5$ & $2.4 \mathrm{E}-2$ & $2.7 \mathrm{E}-12 \mid$ & & & & & $\frac{-61}{2} d-8.00$ & $\frac{-58}{2} \cdot e^{5}-2.4$ & $\frac{20.47}{11}-2.40$ & $-1.58 E-25$ \\
\hline${ }^{3} \mathrm{H}$ & $1.5 \mathrm{E}-\mathrm{\theta}$ & $5.6 \mathrm{E}-2$ & $3.1 E-14$ & & & & & & $\frac{-100}{2} e^{7}-5.6$ & $\frac{130}{2} e^{19} 5.60$ & 5. $30 E-28$ \\
\hline${ }^{14} \mathrm{C}$ & $5.2 E-7$ & $1.2 \mathrm{E}-4$ & $3.1 E-14$ & & & & & & & $\frac{-17.79}{2} e^{9} 0.015$ & $E-26$ \\
\hline $83^{239} \mathrm{Pu}$ & 6. $8 \mathrm{E}-7$ & & & & & & $2=2$ & 5 & & ihjEdhkAhjk & $-1.29 E-24$ \\
\hline & $1.7 \mathrm{3E}-10$ & {$[S D$} & $\mathrm{j} y \mathrm{hj})]^{2}$ & & & & & & & & \\
\hline 11. & $r\left(\hat{\theta}_{h}\right)=1$ & $\left\{d_{h}\right.$ & ]$\left.^{2}\right\}+$ & & & 1.73E-10 & 5.51 & $E+13$ & $29 E-24$ & $1.02 \mathrm{E}-10$ & $=\operatorname{Var}\left(\hat{E}_{h}\right)$ \\
\hline
\end{tabular}

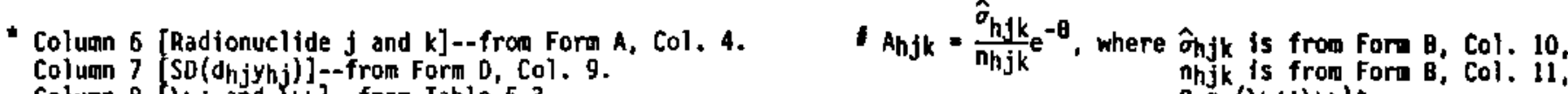

Columin 8
Column 9 nhjk is from Forn B, Col. 11, and $\theta=\left(\lambda h g+\lambda_{h k}\right) t$. 
1. Facility/Scenario and Stratua: $115 \mathrm{D} / \mathrm{DR}$ Rosidential-Hone Garden Sconario - Uain Floor and Basenent (oxcept small portion of Dryer Roos (1)

2. Preparer's Nano: G. F. Piepol

3. Date Prepared: $6 / 28 / 86$

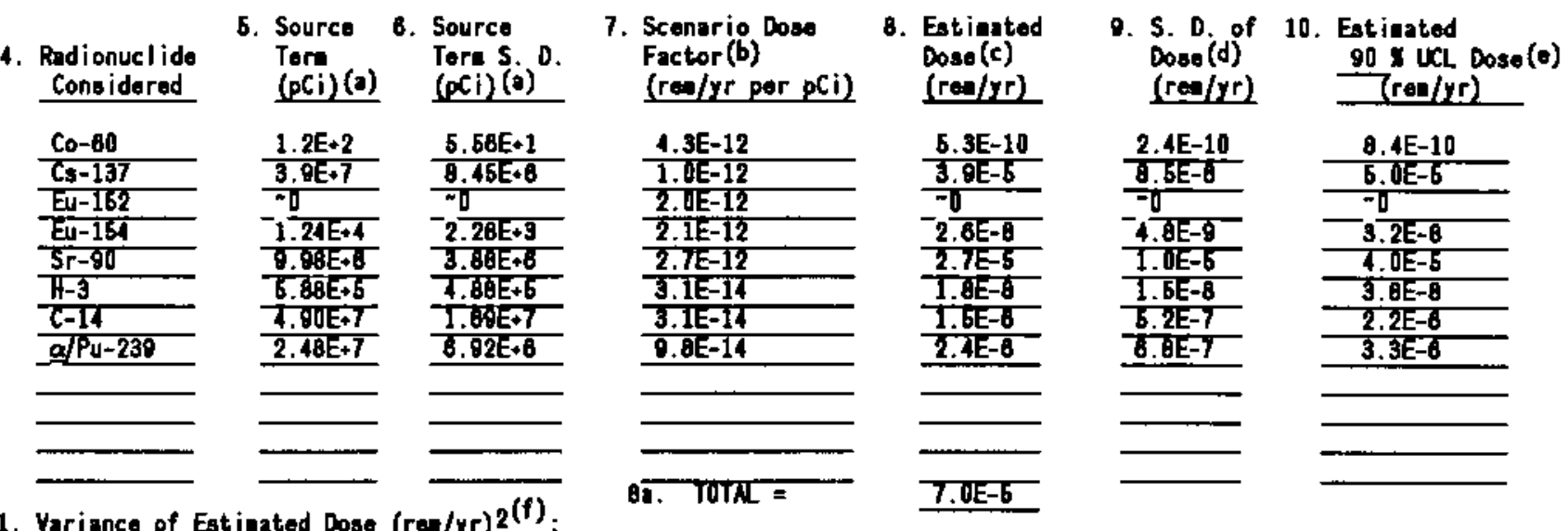

1. DE-10

(a) Fran Fora $B$ - Source Tora lorksheet (coluan 10 or 12), for $T=100$ years.

(b) Fron Fron C - Availability, Fora F - Area, Forn O - Depth, or Forn H - Mass Correction Dorksheots, as appropriate.

(c) Calculate as the product of Coluns 5 and 7.

(d) Calculate as the product of Colunns 6 and 7.

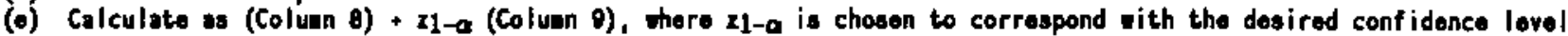
fron Table 5.5 .

(f) Calculate using Procedure 3.2.2, Coluans 7, 9, and Colune $\theta, 0,10$, and 11 fros Fora $A$ - Sunary Statistica Torksheat on Forn E (Dose Variance Calculation Torkaheet). 
1. Facility/Scenario and Stratum: 115-D/DR - Agricultural Sconario - Wain Floor and Basement (oxcept small portion of Dryer Roou (1)

2. Proparor's Namo: G. F. Piepel

3. Date Prepared: $6 / 25 / 80$

4. Stratur Hass ${ }^{(a)}$ (grans): $1.86 E+7$ (a)

5. Number of Years of Decay: 100 (t)

7. Uean Con- 6. Stratur Concentration contration

8. Radionuclide Congidered

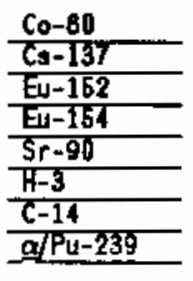

S. D. (b) (pci/a) (b)

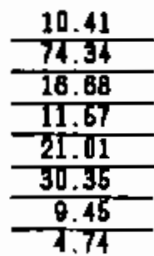

9. Nunber of Sanples. in Stratu nhi (b)

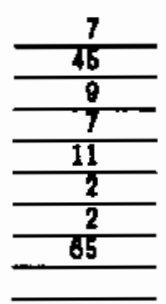

10. Source Thi (d)

$1.73 \mathrm{E}+8$

$1.2 \mathrm{EE}+9$

$\frac{2.77 \mathrm{E}+\mathrm{d}}{1.82 \mathrm{E}+\mathrm{6}}$

$\frac{1.82 E+8}{3.40 E+8}$

5. $1.57 \mathrm{E}+\mathrm{C}$ T.G7E+7

(a) Strata ara dofined to consist only of contaminated aterial

(b) Copy fron Sumery Statistics Table (Tablo 5.2.1).

(c) Calculate as Itell 4 times Iten 7.

(d) S. D. $\left(y_{h i}\right)=\left(\frac{w_{h}^{2} h_{i}}{n_{h i}}\right)^{1 / 2}$

(e) Calculate as Iten 10 tines o- $\lambda_{j}$ t there $\lambda_{i}=$ decay constant for radionuclide $i$ (from Table 5.2.3) and $t=$ nuaber of years of decay

(f) Calculate as Iten 11 tises $-\lambda_{i} t$ vhere $\lambda_{i}=$ decay constant for radionuclide $i$ (from Table 5.2 .3 ) and $t=$ nuaber of yeara of decay (Iten 5).

\begin{tabular}{|c|c|c|}
\hline $\begin{array}{l}\text { Source } \\
\text { Tern } \\
\text { (pi) (o) }\end{array}$ & 13. & $\begin{array}{l}\text { Decayed } \\
\text { S. D. } \\
\text { Yhi }(f)\end{array}$ \\
\hline$\frac{3.91 \mathrm{E}+2}{1.2 \mathrm{kE}+\mathrm{E}}$ & & $\begin{array}{l}1.78 E+2 \\
2.67 E+7 \\
.6\end{array}$ \\
\hline$\frac{\frac{3.00 E+4}{3.17 E+1}}{\frac{1.66 E+6}{1.55 E+8}}$ & & $\frac{\frac{7.17 E+3}{1.22 E+7}}{\frac{1.65 E+6}{5.34 E+7}} \frac{1.19 E+7}{2.19}$ \\
\hline
\end{tabular}


Forn C - Availability Correction Dorkshoot

1. Facility/Sconario and Stratun: 115 D/DR Agricultural Scenario - Whin Floor and Basonent (except suall portion of Dry Roon (1)

2. Preparer's Hane: Q. F. Piepal

3. Dato Prepared: $8 / 28 / 86$

6. Unuodifiod Doso Factors (b)

4. Radionuclide Considered

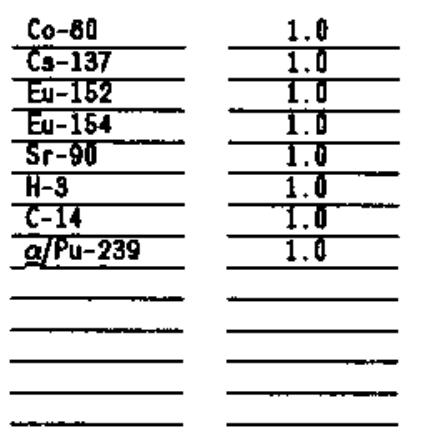

Ba. Inhalation ob. Ingestion (res/yr por $\mathrm{pCi}$ ) (rem/yr por $\mathrm{pCi}$ )

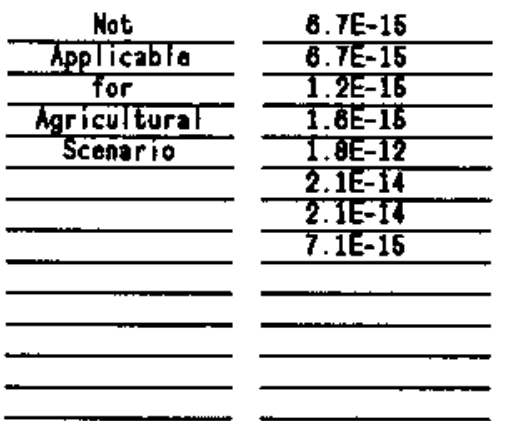

(a) $\mathrm{PF}=1.0$ for radionuclidea not contained in activatod notals. $\mathrm{PF}=2 \mathrm{t}$ (corrosion rate $\mathrm{cm} / \mathrm{yr}$ )/(thickness in $\mathrm{cu}$ ).

(b) From Table 2.2

(c) Calculated as the product of coluang 5 and $\theta$ by radionuclide.

(d) Couplote this colunn only for the Residential/Home Gorden scenario. The scenario dose factors are calculatod as coluen $7 a$ plus Coluan $7 \mathbf{b}$.
7. Corroctod Dose Factora (c) 7a. Inhalation 7b. Ingestion (ron/yr per pCi) (reo/yr per pCi)

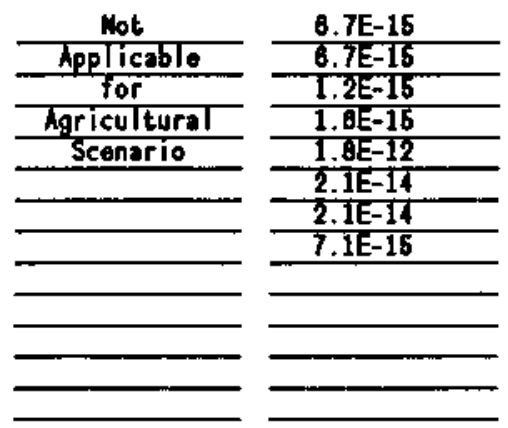

8. Residential/HonoGardon(d) Sconario Dase Factors (rou/yr per $\mathrm{pCi}$ )

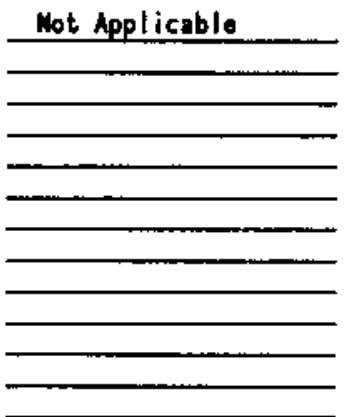


Form G. Depth Correction Worksheet

1. Facility: $115 \mathrm{D} / \mathrm{DR}$ Agricultural Scenario - Main Floor and Basement (except for small portion of Dryer Room \#1)

2. Preparer's Name: G.F.Piepel

3. Date Prepared: $6 / 26 / 86$

4. Depth of $\mathrm{Clean}$ overburden $3.35 \mathrm{~m}$.

5. Calculate depth correction factor (DCF) as OCF $=\mathrm{e}^{-0.92 \text { (Depth) }}=0.046$.

If Depth $>10$ meters DCF $=0.0$.

6. Radionuclide 7. Ingestion $D F(\mathrm{rem} / \mathrm{PCi})(\mathrm{a})$

8. Corrected Ingestion Co-60

$6.7 \mathrm{E}-15$

Cs-137

$6.7 \mathrm{E}-15$

Eu-152

1.2E-15

Eu-154

1. $6 \mathrm{E}-15$

Sr-90

$1.8 \mathrm{E}-12$ $\mathrm{DF}(\mathrm{rem} / \mathrm{pC} \mathrm{i})$ (b)

$$
\mathrm{H}-3
$$

2.1E-14

3. $1 \mathrm{E}-16$

$\frac{\mathrm{C}-14}{\mathrm{Pu}-239}$

2.1E-14

$7.1 \mathrm{E}-15$

3.1E-16

5.5E-17

7. $4 \mathrm{E}-17$

8. $3 E-14$

$9.7 \mathrm{E}-16$

9.7E-16

$\frac{2.1 \mathrm{E}-14}{7.1 \mathrm{E}-15}$

3. $3 \mathrm{E}-16$
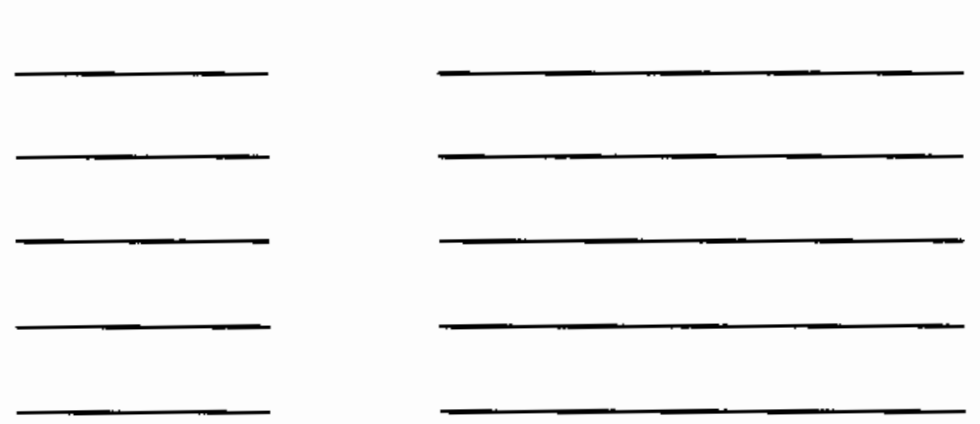

(a) From Area Correction or Availability Worksheet.

(b) Calculated as Item 5 times Column 7. 
Form E--Dose Variance $\left[\operatorname{Var}\left(\mathbb{U}_{h}\right)\right]$ Ca]culation Horksheet for Stratum $h$

1. Facility and Stratum: 1150/DR - Main floor \& basement (except for small portion of Dryer Room 11 )

1. facility and Stratun: Agricultural Scenario

2. Preparer's Name: GF Piepel 3. Date Prepared:_6/25/86 4. Stratum Mass $\left(m_{h}\right): 1,66 E+7 g$ 5. Decay Tine $(t): 100 \mathrm{yr}$

\begin{tabular}{|c|c|c|c|c|c|c|c|c|c|c|c|}
\hline \multirow{4}{*}{$j \mid \begin{array}{l}6 . " \\
\text { Radio } \\
\text { nucli } \\
\text { de hj }\end{array}$} & & & & \multicolumn{7}{|c|}{ Ahjk! } & \multirow{4}{*}{$\frac{10 .}{d_{h j^{j}}\left[d_{h k^{\top}} h j k\right.}$} \\
\hline & & & & 2 & 3 & 4 & 5 & 6 & 7 & & \\
\hline & & Radionu & clide hk: & $\frac{137}{25 s}$ & $\frac{152 \mathrm{EU}}{5525}$ & $\frac{154 \mathrm{Eu}}{856}$ & ${ }^{90} \mathrm{sr}$ & ${ }^{3} \mathrm{H}$ & ${ }^{14} \mathrm{C}$ & $239 p_{u}$ & \\
\hline & SD(dhjyhj & 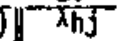 & $\left|\frac{1}{d h j}\right| d h k:$ & $3.1 E-16$ & $5,5 E-17$ & $7.4 E-17$ & $8.3 \mathrm{E}-14$ & $\frac{9.0}{9.7 E-16}$ & $\frac{1.2 E-4}{9.7 E-16}$ & $\frac{2.9 E-5}{3 \cdot 3 E-16}$ & \\
\hline $\operatorname{sen} 2+8$ & & & & -485.43 & 230.84 & $-69.4-1$ & 123.94 & 30999 & $-67]_{8}^{3}$ & -19.75 & \\
\hline${ }^{60} \mathrm{Co}$ & $5.5 \mathrm{E}-14$ & $1.3 \mathrm{E}-1$ & $3.1 \mathrm{E}-16$ & $7 \quad 15.3$ & $4 \quad e^{-18.2}$ & $20-21.5$ & $5-15.4$ & $1<18.6$ & 1 & $7-13.0$ & $-3.16 E-34$ \\
\hline $2137 \mathrm{Cs}$ & $8.3 \mathrm{E}-9$ & 2. $3 E-2$ & $3.1 E-16$ & & $\frac{-630}{7} e^{49} 7.50$ & $\frac{-4 \theta \cdot 50}{5} e_{10.0}$ & $\frac{3980}{9} e^{54} 4.70$ & $\frac{19,938}{1} e^{-9} .90$ & $\frac{-3901}{J} e^{\frac{1}{2}}$ & $\frac{-174}{43}-\frac{03}{2} \cdot 30$ & $-1.03 E-29$ \\
\hline $3152 \mathrm{Eu}$ & 0 & $5.2 \mathrm{E}-2$ & $5.5 \mathrm{E}-17$ & & & $\frac{23.05}{7} e^{-13.7}$ & $\frac{-28.09}{7} e^{-9} 7.60$ & $\frac{-575}{2} e^{4} 10.8$ & $\frac{-471}{2}-e^{4} 5.2$ & $\frac{-14}{9} e^{7}-5.20$ & $-7.82 E-32$ \\
\hline $4 \mid 15{ }^{4} \mathrm{Eu}$ & 5. $3 \mathrm{E}-13$ & $8.5 \mathrm{E}-2$ & $7.4 E-17$ & & & & $\frac{-30.78}{7}-10.9$ & $9 \frac{48,8}{2} \mathrm{e}-14.1$ & $\frac{-41.8}{2} e^{6} .51$ & $\frac{8,71}{7}-0.50$ & $-7,93 E-34$ \\
\hline${ }^{90} \mathrm{Sr}$ & 3056 & $45 ?$ & $18=35,4$ & & & & & $-61-8-8.00$ & $-58.5-2.4$ & $28.47-2.40$ & \\
\hline$S r$ & $1.0 \mathrm{t}-6$ & $5 \times 4 t-2$ & $0.05-1$ & & & & & & 2 & $11 \quad 27$ & $-2.05 \mathrm{E}-28$ \\
\hline${ }^{3} \mathrm{H}$ & 1. $5 E-9$ & $5.6 E-2$ & $9.7 E-1 E$ & & & & & & $\frac{-100}{2}-5.6$ & $\frac{130}{2}-5.60$ & $-1.10 E-31$ \\
\hline${ }^{14} \mathrm{C}$ & $5.2 \mathrm{E}-\theta$ & $1.2 \mathrm{E}-4$ & $|9.7 \mathrm{E}-16|$ & & & & & & & $\frac{-17}{2} \mathrm{e}^{79} 0.015$ & $-2.81 E-30$ \\
\hline $8239 \mathrm{pu}$ & $7.2 \mathrm{E}-9$ & & & & & & & & & $h j \Sigma \delta h_{h} k^{A} A h j k$ & $=-2.19 E-2 \theta$ \\
\hline & $1.01 E-12$ & $=\varepsilon[S 0($ & $\left.\left(y_{h j}\right)\right]^{2}$ & & & & & & & & \\
\hline 11. & $\left.b_{h}\right)=\{$ & & ) $\left.]^{2}\right\}$ & & & $1.01 \mathrm{E}-1$ & 5.5 & $51 E+14$ & $19 E-28$ & $8.85 \mathrm{E}-1 \mathrm{~g}$ & $=\operatorname{Var}\left(\hat{t}_{h}\right)$ \\
\hline
\end{tabular}

- Column 6 [Radionuclide $\mathbf{j}$ and $k$ ]--from Form
Column 7 [SD(dhjyhj)]--fram Form 0 , Col. 9.
Column 8 [ $\lambda_{h j}$ and $\lambda_{h k}$ ]--from Table 5.3.

Column 9 [dhj and $d_{h k}$ ]--from form $D$, Col. 7 .
$A_{h j k}=\frac{\hat{\sigma}_{h j k}}{n h j k} e^{-\theta}$, where $\hat{o}_{h j k}$ is from Form B, col. 10, nhjk is from Form B, Col. 11, and

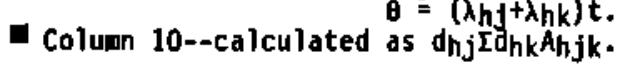




\section{Foru D - Stratua Dose Caleulation Dorksheot}

1. Facility/Sconario and Stratua: $115 \mathrm{D} / \mathrm{DR}$ Agricultural Scenerio - Main Floor and Bosement (oxcept suall portion of Dryor Roan (1)

2. Preparer's Nawe: G. F. Piepel

3. Date Prepared: $8 / 28 / 86$

5. Source 6. Source

4. Radionuclide Considered

Co-80

$\frac{\mathrm{Co}-80}{\mathrm{Cs}-137}$ EN-152 $\frac{\text { Eu-154 }}{5 r-90}$

$\mathrm{H}-3$

$\mathrm{C}-14$

욜-239

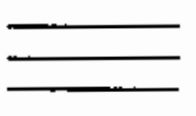

1. Variance of Estiated Dose $(\mathrm{rea} / \mathrm{yr})^{2^{(f)}}$

Source 6. Source
Tern (a) 5 . D.
(pCi) (a) $\quad$ (pCi) (a)

(pCi)(a) $(p C i)(a)$

$3.01 E+2-1.78 E+2$ $\frac{1.23 E+8}{-3.90+4} \frac{2.87 E+7}{-7}$ 3.17E+7 $1.86 E+6$ 1.56E+6

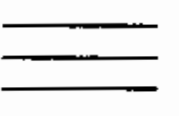

7. Scenario Doso Factor (b) (res/yr por $\mathrm{pCi}$ )

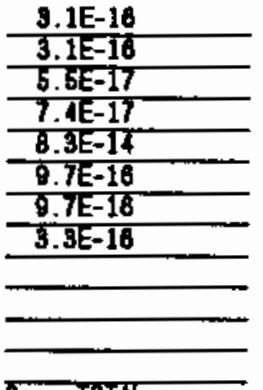

83. TOTR =
8. Estinated Doso(c) (rea/yr)
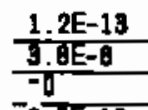

2.7E-12

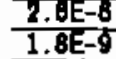

1.BE-7

$2.6 \mathrm{E}-9$
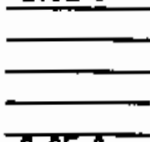

9. S. D. of 10. Estieated Dase(d) $00 \times$ ULL Dose(0) (rea/yr) (ren/yr)
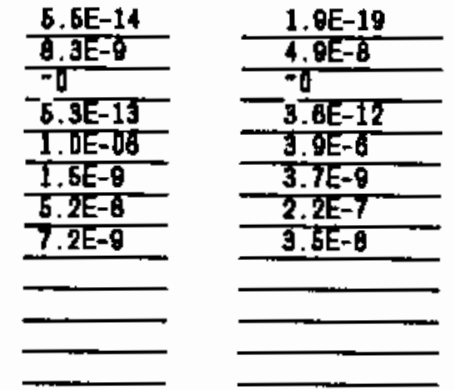

(a) Fron Forn $B$ - Source Tera Worksheot (colunn 10 or 12), for $T=100$ years.

(b) Fron Form C - Availability, Forn F - Area, Forn 0 - Depth, or Form H - Wass Corroction Dorksheets, as appropriate.

(c) Calculate as the product of Columns 5 and 7.

(d) Calculate as the product of Colunns 6 and 7 .

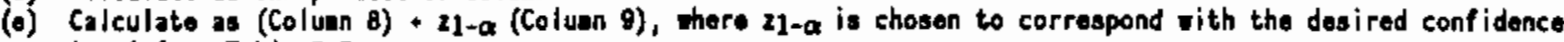
level fron Tablo 5.5 .

(f) Calculate using Procoduro 3.2.2, Coluans 7, D, and Coluans 8, D, 10, and 11 fros Forn A - Sunary Statistics Vorksheet on Fora $E$ (Dose Variable Calculation Morksheot). 
Forn A - Sunary Statiatica Tablo - Egtigatod Weans, Standard Deviations, and Covariances per Stratur

1. Facility and Stratum: 115 D/OR-D Tunnel (Labeled as TD in Table A.1)

2. Preparer's kane: G. F. Piopel

5. Hean 6. S. D.

4. Radionuclide $\bar{x}_{\mathrm{hi}}$ ohi

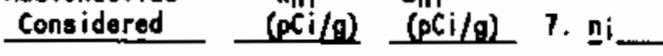

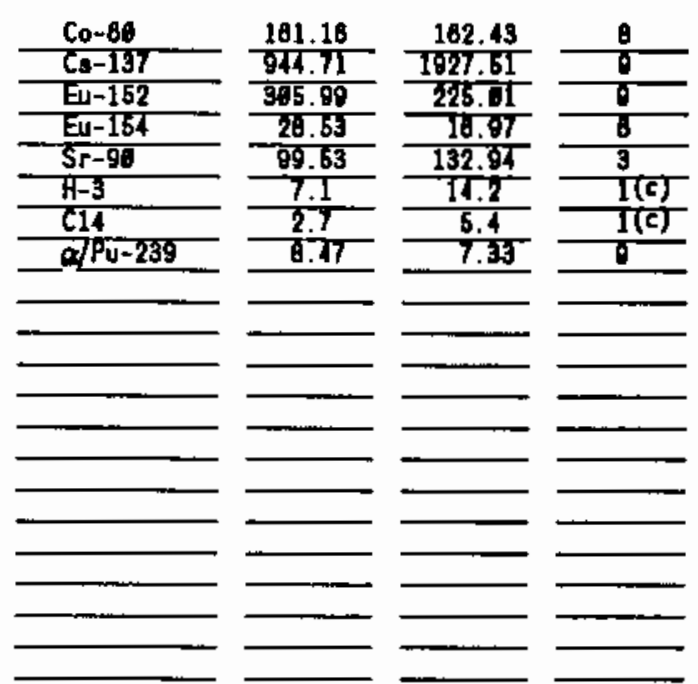

(a) Hoto: Coluns 8-11 rill be nuch Consents:

(b) Insufficiont data to estinate covariance. Values given vore coosuted by taking into account other aspects of the data. This ras done to cosplete this exanple and is not recounended as general practice. For nhij $\leq 2$, use nhij=1 in

(c) Insufficiont to coeputo S.D. Valuos givon conputed assuning $2 / x=2.0$, which was done to conplote this exanplo.
3. Date Prepared: 8/25/86

\section{Number of Sanples}

for which both

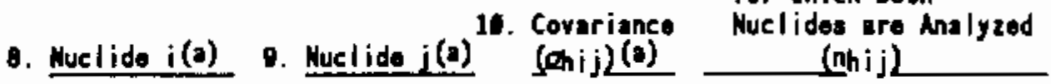

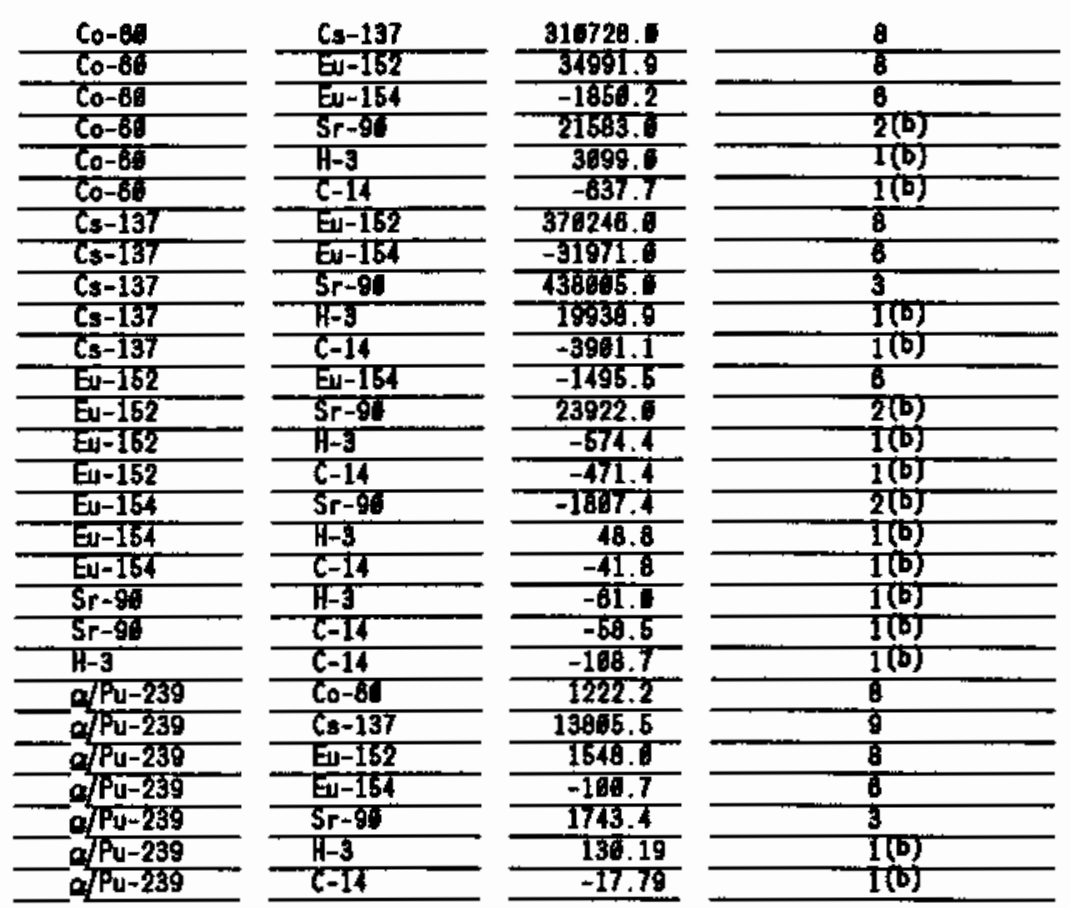


1. Facility/Sconario and Stratum: 116 D/DR - D Tunnol, Agricultural Sconario

2. Preparer's Nano: G. F. Piepel

3. Date Prepared: $8 / 28 / 8 B$

4. Stratue Hass (a) (grans): $4.01 \mathrm{E}+6$ (o)

5. Nunber of Years of Decay: $\underline{100}(t)$

7. Wean Con- 8. Stratus Concentration contration

8. Radionucl ide Considered

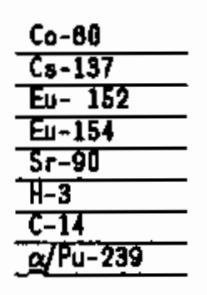
in Stratur. S. D., (b) (pci/g) (b)

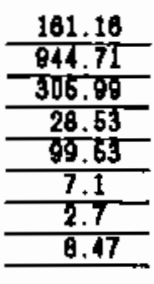

8. Nuaber of (pCi/g)

\begin{tabular}{c}
$\frac{182.43}{1927.51}$ \\
\hline 225.01 \\
\hline 16.97 \\
\hline 132.94 \\
\hline 14.2 \\
\hline 5.4 \\
\hline 7.33 \\
\hline
\end{tabular}
Saeples in Stratu

10. Sourc*

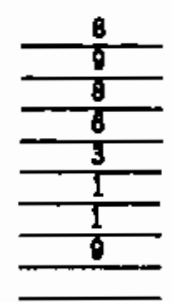
Thi (d)

11. S. D.

6. $48 \mathrm{E}+8$ $3.705+9$

$\frac{1.23 \mathrm{E}+9}{1.14 \mathrm{E}+9}$

1.14E+9

$3.99 \mathrm{E}+8$

$2.85 E+7$

$\frac{1.08 E+7}{3.17 E+7}$

(a) Strata aro dofined to consist only of contaninated aatorial.

(b) Copy fron Fora $A$ - Sunary Statistics Table (Table 5.2.1).

(c) Calculate as Iten 4 tiess Itom 7 .

(d) S. D. $\left(y_{h i}\right)=\left(\frac{\sigma_{h}^{2} h_{i}}{n_{h i}}\right)^{1 / 2}$

(e) Caiculate as Itea 10 tises o- $\lambda_{i} t$ where $\lambda_{i}=$ decay constant for radienuclide $i$ (froe Table 5.2 .3 ) and $t=$ nuaber of years of decay (Iten 5).

(f) Caleulate as Iten 11 tines o- $\lambda_{i}$ t where $\lambda_{i}=$ decay constant for radionuclide $i$ (from Tablo 5.2 .3 ) and $t=$ nunber of yours of decay (Iten 5). 


\section{Forn C - Availability Correction Norkshoet}

1. Facility/Scenario and Stratua: 115 D/DR-D Tunnel, Agricultural Scenario

2. Preparor's Mano: Q. F. Piopel

3. Date Prepared: $\theta / 26 / \theta 6$

- Radionuclido

6. Roduction

6. Uheodified Dose Factors(b)

Considered

Factor (a) 6a. Inhalation 6b. Ingestion

Co-60

1.0 (ron/yr per $p C i)$ (ren/yr per $p C i)$

7. Corrected Dowe Fectors(c) 72. Inhalation 7b. Ingestion (ren/yrper pCi) (rea/yr per pCi)

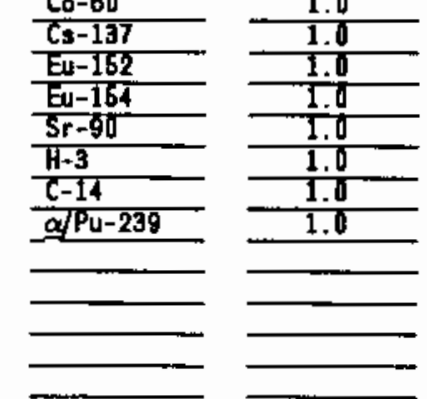

(a) Rif $=1.0$ for radionuclides not contsined in activated aotalo. PF = $2 \mathrm{t}$ (corrosion rate $\mathrm{ca} / \mathrm{yr}$ )/(thickness in $\mathrm{co}$ ).

(b) Fron Tablo 2.2

(c) Calculated as the product of columns 5 and $B$, by radionuclide.

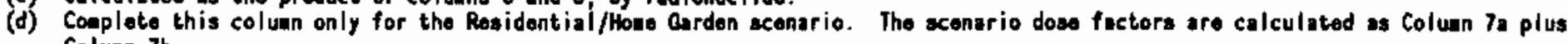
Coluen $7 \mathrm{~b}$.
6. Resident ial/HoneGarden(a) Scenario Dase Factors (rou/yr por pCi)

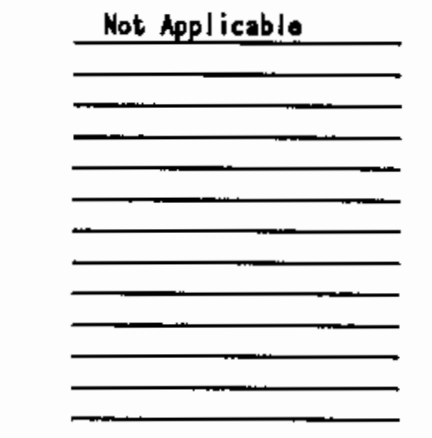

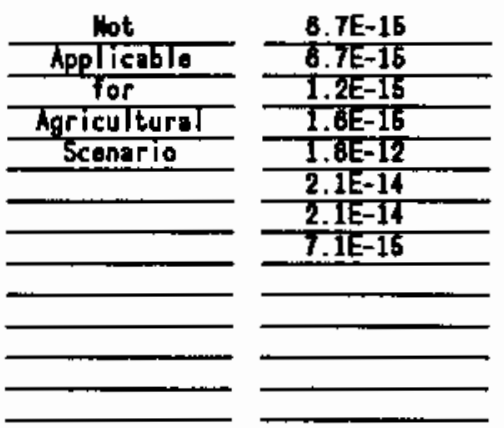

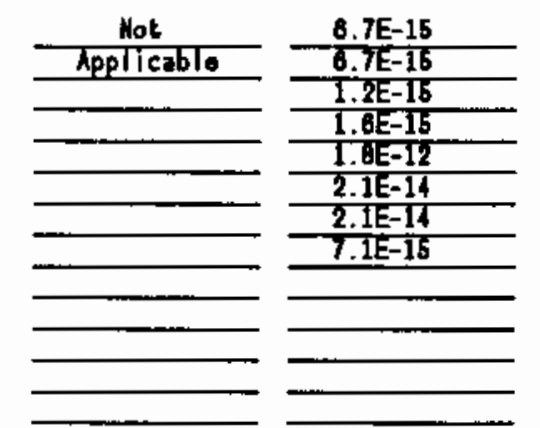




\section{Form $\mathrm{G}$ - Correction Worksheet}

1. Facility: 115 D/DR - D Tunnel, Agricultural Scenario

2. Preparer's Name: G. F. Piepel

3. Date Prepared: $6 / 26 / 86$

4. Depth of Clean overburden $3.35 \mathrm{~m}$.

5. Calculate depth correction factor (OCF) as DCF $=\mathrm{e}^{-0.92(\text { Depth) }}=0.046$.

If Depth $>10$ meters DCF $=0.0$.

6. Radionuclide 7. Ingestion $D F(\mathrm{rem} / \mathrm{PCi})(\mathrm{a})$ Co-60 Cs-137 Eu-152

Eu-154

$\frac{\frac{S r-90}{H-3}}{C-14} \frac{\mathrm{Pu}-239}{-\alpha / \mathrm{Pu}}$

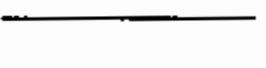

$6.7 \mathrm{E}-15$

$6.7 \mathrm{E}-15$

$1.2 \mathrm{E}-15$

$1.6 \mathrm{E}-15$

1.8E-12

$2.1 \mathrm{E}-14$

$2.1 \mathrm{E}-14$

7.1E-15
8. Corrected Ingestion $\mathrm{DF}(\mathrm{rem} / \mathrm{pCi})(\mathrm{b})$

$3.1 \mathrm{E}-16$

$3.1 E-16$

$5.5 \mathrm{E}-17$

7. $4 \mathrm{E}-17$

8.3E-14

$9.7 \mathrm{E}-16$

9.7E-16

$3.3 \mathrm{E}-16$

(a) From Area Correction or Availability Worksheet.

(b) Calculated as Item 5 times Column 7. 


\section{Forn E--Dose Variance [Var( $\left.\underline{G}_{h}\right)$ ] Calculation Horksheet for Stratun h}

1. Facility and Straturu: 115D/DR - D Tunnel - Agricultural Scenario

2. Preparer's Name: GF P1epel 3. Date Prepared: 6/25/86 4. Stratur Mass (mh):4.01E+6g 5. Decay T1me $(t): 100 \mathrm{yr}$

\begin{tabular}{|c|c|c|c|c|c|c|c|c|c|c|c|}
\hline \multirow{4}{*}{$\left|\begin{array}{c}\text { 6." } \\
\text { Radio } \\
\text { nucli } \\
\text { de hj }\end{array}\right|$} & & & & \multicolumn{7}{|c|}{ Ahjk } & \multirow{4}{*}{ 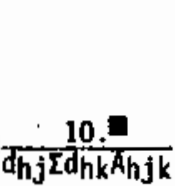 } \\
\hline & & & -1]do phe & & & 4 & 5 & $\frac{6}{34}$ & $\begin{array}{l}7 \\
-14 r\end{array}$ & & \\
\hline & 7.* & $\begin{array}{c}\text { Radjonuc } \\
8 .{ }^{*}\end{array}$ & $\begin{array}{l}\text { elide hk: } \\
\text { 9." }\end{array}$ & $\frac{137 \mathrm{Cs}}{2,3 \mathrm{E}-2}$ & $\frac{152 \mathrm{EU}}{5.2 \mathrm{E}-2}$ & $\frac{154 \mathrm{EU}}{8.5 \mathrm{E}-2}$ & $\frac{90 \mathrm{Sr}}{2.4 E-2}$ & $\frac{3 \mathrm{H}}{5.6 E-2}$ & $\frac{14 \mathrm{C}}{1.2 \mathrm{E}-4}$ & $\frac{239 \mathrm{Pu}}{2.9 E-5}$ & \\
\hline & $\overline{S D}\left(d_{h j} y_{h j}\right)$ & 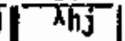 & dij $\backslash$ & $3.1 \mathrm{E}-16$ & $5.5 E-17$ & $7.4 E-17$ & $8 \cdot 3 E-14$ & $9.7 E-16$ & 9.7E-14 & $3.3 E-16$ & \\
\hline${ }^{60} \mathrm{Co}$ & $1.6 \mathrm{E}-13$ & 1. $3 \mathrm{E}-1$ & $3,1 \mathrm{E}-1 \mathrm{E}$ & $\frac{3.11}{8} e^{2}+5.3$ & $\frac{3.50}{8} \mathrm{et}_{18.2}^{4}$ & $\frac{-1.85}{6}-\mathrm{e}^{2+3}$ & $\frac{2.16}{2} \mathrm{e}^{4}{ }^{4}$ & $\frac{3.10 \mathrm{~g}}{1}-39.6$ & $\frac{-657}{1} e^{7} 3.0$ & $\frac{3.7065}{8} e^{5}=0$ & $2.57 \mathrm{E}-32$ \\
\hline $2{ }^{2}{ }^{137} \mathrm{Cs}_{\mathrm{S}}$ & $1.2 \mathrm{E}-7$ & $2.3 \mathrm{E}-2$ & $3.1 \mathrm{E}-1 \mathrm{E}$ & & $\frac{-319}{6} e^{1}>00$ & $\frac{4.39855}{3} e^{-5}$ & $\frac{1.99 \mathrm{e}^{+4}}{1}+.70$ & $\frac{-390 j 4}{1-4.90}$ & $\frac{-1495.5}{6} e^{-5.31}$ & $\frac{2.392-4}{2} e^{2}, 30$ & 4. $04 E-27$ \\
\hline${ }^{152} \mathrm{Eu}$ & 0 & $5.2 E-2$ & $5.5 E-11$ & & & $\frac{-574}{1} e^{14}{ }_{13.7}$ & 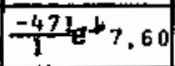 & $\frac{-1807}{2}$ eio. & $\frac{48.8}{1} e^{3} .21$ & $\frac{-41.8}{1-e^{8}} 5.20$ & $3.37 E-31$ \\
\hline \begin{tabular}{|l|l|}
454 & $\mathrm{Eu}$ \\
\end{tabular} & 1. $7 E-32$ & 8. $5 \mathrm{E}-2$ & $7.4 E-1\}$ & & & & $\frac{-61}{1} e^{0}-10.9$ & $\frac{-56.5}{1} 874.1$ & $\frac{-108}{1-7}-8.51$ & $\frac{1222}{\theta} e^{2} 8.50$ & $-1.63 \mathrm{E}-31$ \\
\hline${ }^{90} \mathrm{Sr}$ & $2.32 \mathrm{E}-6$ & $2.4 E-2$ & $8.3 \mathrm{E}-1$, & & & & & $\frac{1.38+4.00}{9}$ e7. & $\frac{1548}{8} e^{-}-4.4$ & $\frac{1000}{6}-2.40$ & $1.40 E-25$ \\
\hline${ }^{3} \mathrm{H}$ & $1.0 \mathrm{E}-10$ & $5.6 \mathrm{E}-2$ & $9.7 \mathrm{E}-1 \mathrm{C}$ & & & & & & $\frac{1743}{3} \cdot e^{4}-5.61$ & $\frac{130.19}{1} e^{-2.60}$ & $2.00 \mathrm{E}-2 \mathrm{~B}$ \\
\hline${ }^{14} \mathrm{C}$ & $1.0 \mathrm{E}-8$ & $|1,2 \mathrm{E}-4|$ & $9.7 \mathrm{E}-1 \mathrm{~d}$ & & & & & & & $\frac{-17.79}{1} 0.001$ & $-5.61 E-30$ \\
\hline $23{ }^{23 y}$ & $1.1 E-8$ & & & & & & & & Id & $h_{j}{ }^{\Sigma d} d k_{k} A_{h j} \mathbf{k}$ & $3.44 E-24$ \\
\hline & $5.40 \mathrm{E}-12$ & $=\Sigma[50(d$ & $\left.\left.h j y_{h j}\right)\right]^{2}$ & & & & $2 m m_{h}<=$ & $61 E+13$ & & & \\
\hline 11. & $\left(\theta_{h}\right)=\{\Sigma$ & dhjy & j) $\left.]^{2}\right\}+$ & & & $5.40 \mathrm{E}-12$ & 2.61 & $E+13$ & $4 E-25$ & $1.00 \mathrm{E}-11$ & $=\operatorname{var}\left(\hat{\theta}_{h}\right)$ \\
\hline
\end{tabular}

- Column 6 [Radionuclide $j$ and $k$ ]--from Form $A$, Col. 4. Column 7 [SD(dhjyhj)]--from Form D, Col. 9.

Colunn 8 [ $\lambda_{h j}$ and $\lambda_{h k}$ ]--from Table 5.3 .

Column $9\left[d_{h j}\right.$ and $\left.d h k\right]$--from form $D$, col. 7 . $t_{\text {Ahjk }}=\frac{\hat{\sigma}_{h j k}}{n h j k} \mathrm{e}^{-\theta}$, where $\hat{o}_{h j k}$ is fron form B, Col. 10 nhjk is from form $B$, Col. 11, and

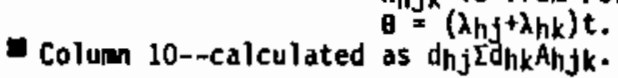


Forn D-Stratun Dose Calculation Porksheet

1. Facility/Sconario and Stratua: 115 D/DR - D Tunnel, Agricultural Scenario

2. Preparer'o Mase: G. F. Piepel

3. Date Prepared: $6 / 26 / 88$

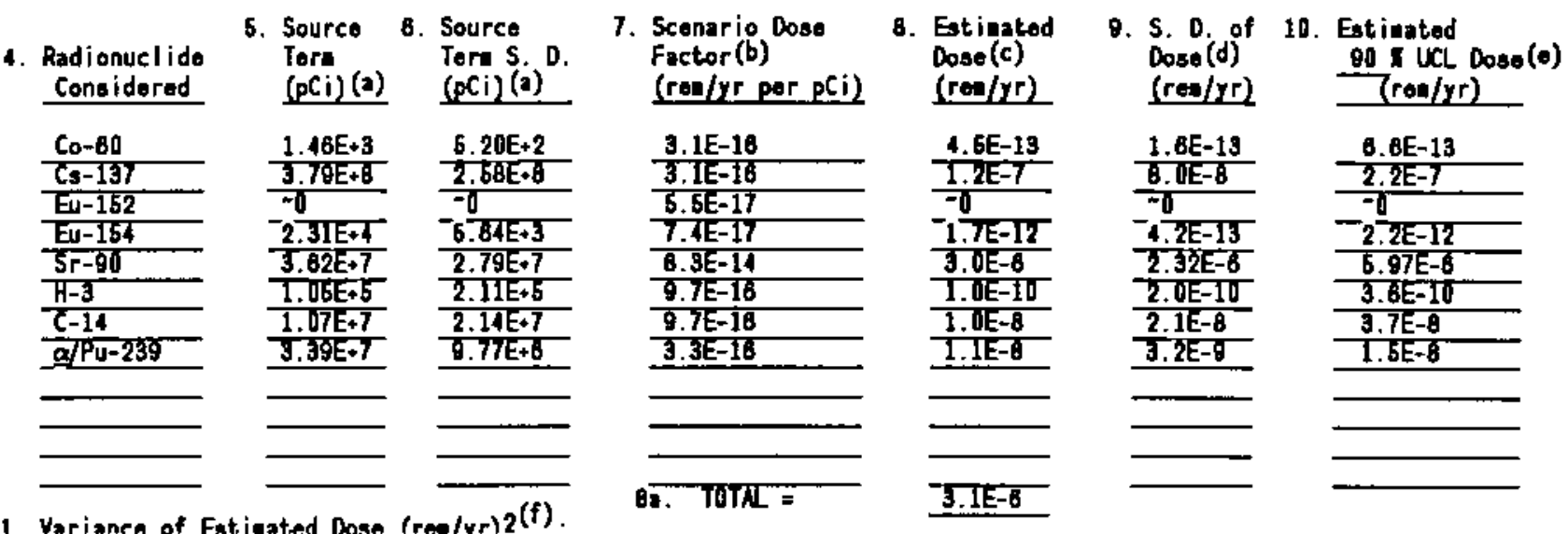

1.0E-11

(a) Fron Fore $B$ - Source Torn Dorksheot (colunn 10 or 12), for $T=100$ years.

(b) Fron Form C - Availability, Forn F - Ares, Forn 0 - Dopth, or Forn H - Hass Correction Worksheats, as appropriate.

(c) Calculate as the product of Columns 5 and 7.

(d) Calculate as the product of Colums $B$ and 7

(e) Caleulate as (Coluin B) $+\mathrm{z}_{1-\alpha}$ (Coluan 9), there $\mathrm{z}_{1-\alpha}$ is chosen to correspond with the desired confidence level

(f) Calculate using Procedure 3.2.2, Colunns 7, 8, and Coluns 8, 9, 10, and 11 fron Fore A-Sunary Statiatics Dorkshoet on Fora $E$ (Dose Yariance Calculation Morksheet) 
Form A - Sunary Statistics Table - Estinated Ueans, Standard Deviations, and Covariances per Stratun

1. Facility and Stratun: 115 D/DR - DR Tunnel, Agricultural Scenario (Labeled as Roon TDR in Tablo A.1)

2. Proparer's Hano: G. F. Piepel

6. Wogn 6. S. D

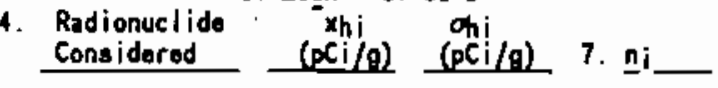

Co-80 Cs-137

Eu-152

Eu-154

Sr-9

C-3

$$
\frac{\frac{2.7}{324.40}}{\frac{35.40}{13.33}}
$$

12.4

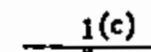

$\frac{116.88}{24.13}$

9.93

6(d)

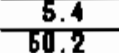

Q $P u-239$

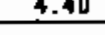

1.14

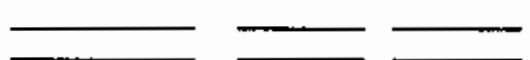

$\longrightarrow \longrightarrow$

$\longrightarrow \longrightarrow$

$\longrightarrow \longdiv { \square } \longrightarrow$

$\longrightarrow \longrightarrow$

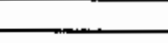

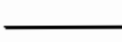

(a) Note: Colunns a-11 will be nuch longor than 4-7.

Conents:

(b) Insufficient data to estimate covariance. values given were conputed by taking into account other aspects of the data. This was done to cosplete this exanple and is not recomended as general practice. For $n_{h i j} \leq 2$, use $n_{h i j}=1$ in any conputations requiring the values.

(c) Insufficient to compute S.D. Yalues given conputed assuming $2 / x-2.0$, wich was done to complete this example.

(d) Value computed fron 3 data values vas artifically seall. Value of 6 chosen.

3. Date Prepared: $6 / 25 / 86$

11. Nunber of Sanples for thich both Nuclides are Analyzed 6. Huclide $i(a)$. Nuclide $j(a)^{10 . ~ C o v a r i a n c e ~}$ (nhij)
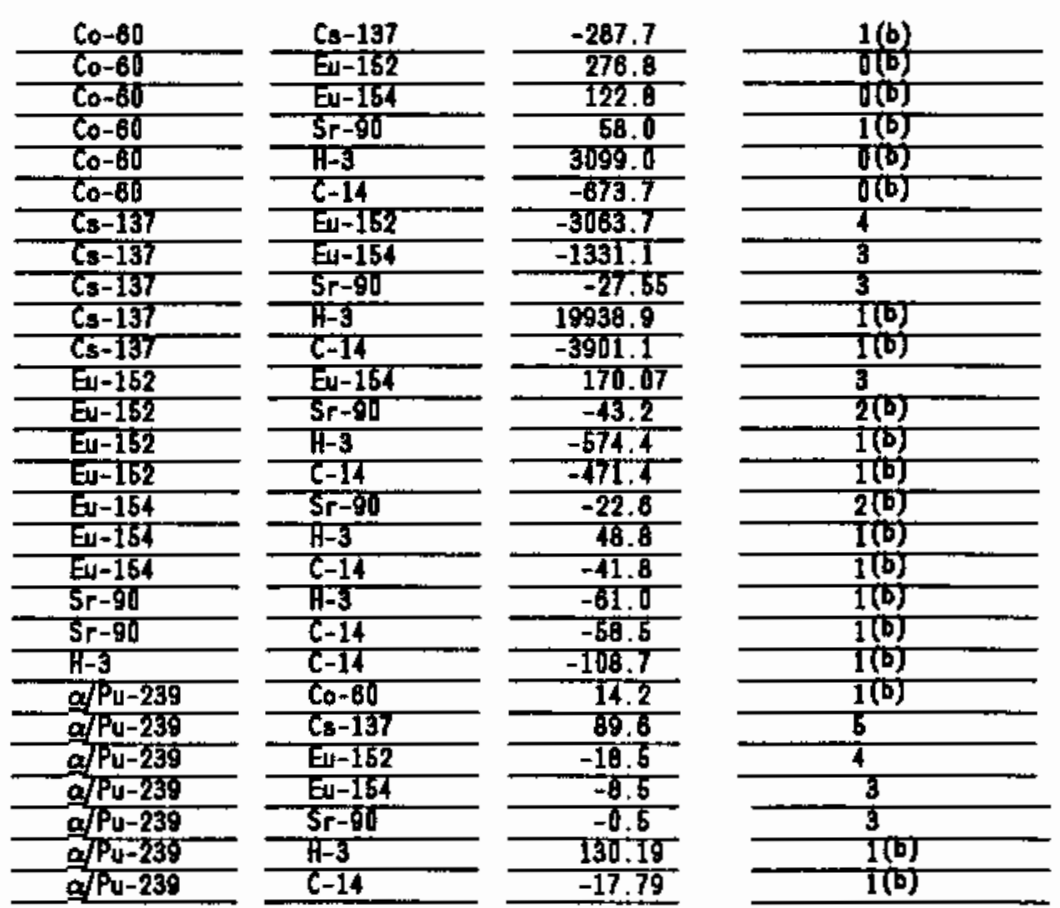

1 (b) 
1. Facility/Scenario and Stratua: 115 D/DR - D Tunnel, Agriculturs/ Sconario

2. Proparer's Nano: 0. F. Piopel

3. Date Proparod: 8/28/86

4. Stratun Mass ${ }^{(a)}$ (grans): 4.01E+B (a)

5. Number of Yoars of Docay: 100 ( $t)$

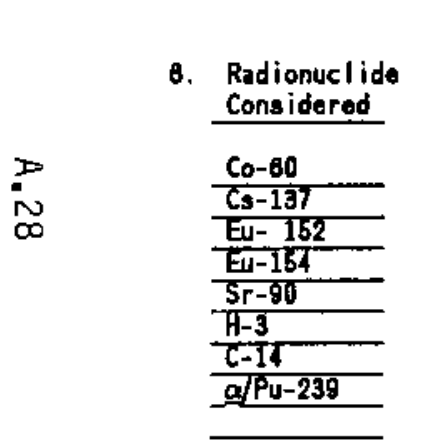

\begin{tabular}{|c|c|}
\hline $\begin{array}{l}\text { Moan Con- } \\
\text { centration } \\
\text { in Stratua, } \\
\text { xhi } \\
\text { (oci } / g)(b)\end{array}$ & $\begin{array}{l}\text { 8. Stratus Con- } \\
\text { contration } \\
\text { 5. } 0 .,(\text { b) } \\
o h i \\
(\mathrm{p} C \mathrm{i} / \mathrm{g})\end{array}$ \\
\hline $\begin{array}{c}161.18 \\
944.71 \\
305.80 \\
20.53 \\
89.55 \\
7.1 \\
2.7 \\
8.47\end{array}$ & $\begin{array}{r}162.43 \\
1927.51 \\
225.01 \\
16.97 \\
132.94 \\
14.2 \\
6.4 \\
7.33\end{array}$ \\
\hline
\end{tabular}

9. Number of Sanplos in Stratus nhis (b)

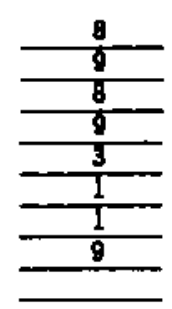

10. Source Thise

6. $48 \mathrm{E}+8$

$\frac{6.40 E+8}{3.79 E+10}$

$\frac{3.79 E+4}{1.25 \mathrm{E}+9}$

$\frac{1.25 E+9}{1.14 E+9}$

3. $89 E+8$

2. $85 \mathrm{E}+7$

$\frac{1.08 E+7}{3.47 E+7}$

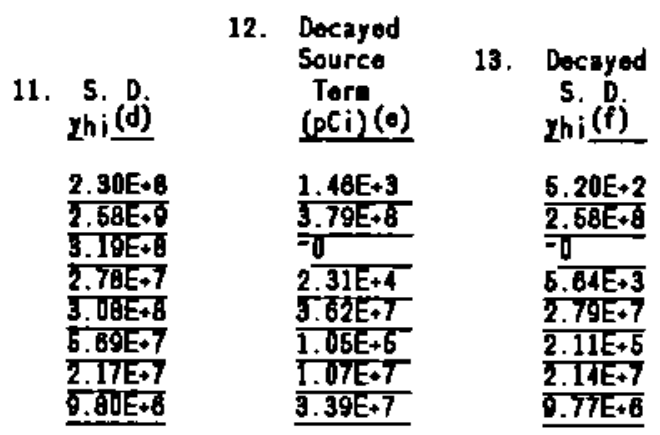

(a) Strata aro dofined to consist only of contauinatod antorial.

(b) Copy fron Fora $A$ - Sunary Statigtics Tablo (Tablo 5.2.1).

(c) Calculate as Ites 4 tiues Iten 7.

(d) S. D. $\left(v_{h i}\right)=\left(\frac{n_{h}^{2} h_{i}}{n_{h i}}\right)^{1 / 2}$

(o) Calculate as Itee 10 tiass o- $\lambda_{i} t$ where $\lambda_{j}=$ decay constant for radionuclide $i$ (from Table 5.2 .3 ) and $t=$ nuaber of years of docay

(f) Calculato as Iten 11 times o- $\lambda_{i}$ t there $\lambda_{i}=$ decay constant for radionuclide $i$ (from Table 5.2 .3 ) and $t=$ nuaber of years of decay (Iten 5). 


\section{Forn C - Availability Correction Worksheat}

1. Facility/Scenario and Stratua: 115 D/DR - D Tunnel, Agricultural Scenario

2. Preparor's Mamo: G. F. Piepel

3. Date Prepared: $8 / 26 / 88$

4. Radionuclido 5. Reduction 6. Unaodified Dose Factors(b) Considered Factor(a) (ron/yr per pCi) (rou/yr per pCi)

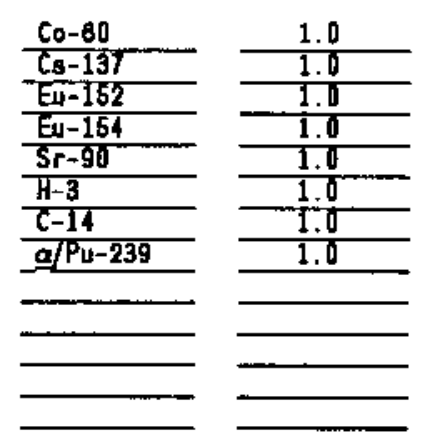

(a) $F=1.0$ for radionuclides not contained in actiratod netale. $\mathrm{PF}=2 \mathrm{t}$ (corrosion rate $\mathrm{cm} / \mathrm{yr}) /($ thickness in $\mathrm{ca}$ ).

(b) Frou Tablo 2.2 .

(c) Calculated as the product of coluens 5 and 8 , by radionuelide.

(d) Camplete this coluan only for the Residential/Hoae Gorden scenario. The sconario dose fuctors are calculated as Coluan $7 a$ plus Colunn $7 b$.
7. Corrected Doso Factors (c) 7a. Inhalation 76. Ingostion (ron/yr por $p(i)$ (ron/yr per $p C i)$
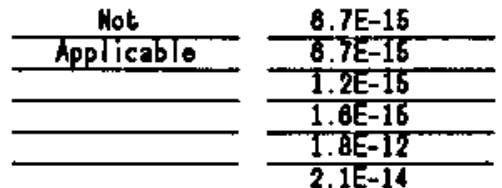

$\longrightarrow \frac{1.1 \mathrm{E}-14}{2.1 \mathrm{E}-14}$

$\longrightarrow \frac{2.1 \mathrm{E}-14}{7.1 \mathrm{E}-15}$

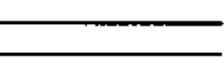

$\bar{\square}$
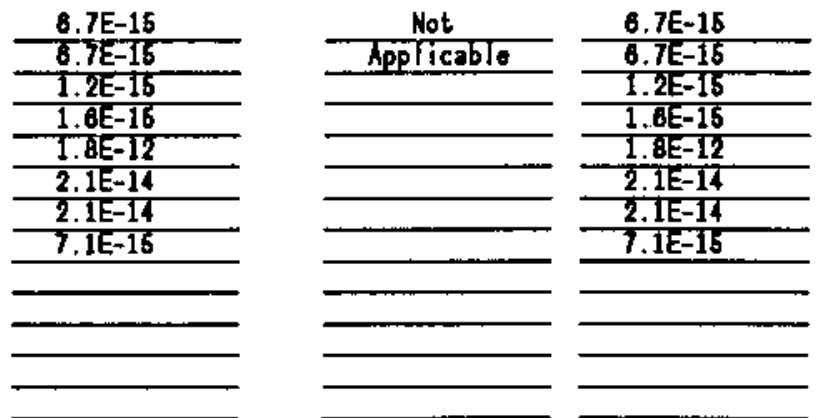

8. Residential/HomoGarden (a) Scenario Dose Factore (rea/yr por pCi)

Hot Applicable

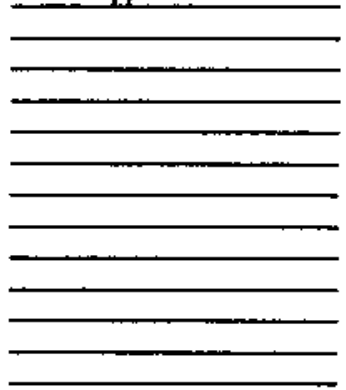

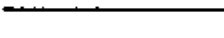




\section{Form G - Depth Correction Worksheet}

1. Facility: 115 D/DR Tunnel, Agricultural Scenario

2. Preparer's Name: G. F. Piepel

3. Date Prepared: $6 / 26 / 86$

4. Depth of Clean overburden $\underline{3.35} \mathrm{~m}$.

5. Calculate depth correction factor (DCF) as DCF $=\mathrm{e}^{-0.92 \text { (Depth) }}=0.046$.

If Depth $>10$ meters DCF $=0.0$.

6. Radionuclide 7. Ingestion $\mathrm{DF}(\mathrm{rem} / \mathrm{PCi})(\mathrm{a})$

8. Corrected Ingestion

\begin{tabular}{l}
$\frac{C 0-60}{C S-137}$ \\
\hline$E u-152$ \\
\hline$E u-154$ \\
\hline$S r-90$ \\
\hline$H-3$ \\
\hline$C-14$ \\
QPu-239
\end{tabular}

\begin{tabular}{c}
$6.7 \mathrm{E}-15$ \\
\hline $6.7 \mathrm{E}-15$ \\
\hline $1.2 \mathrm{E}-15$ \\
\hline $1.6 \mathrm{E}-15$ \\
\hline $1.8 \mathrm{E}-12$ \\
\hline $2.1 \mathrm{E}-14$ \\
\hline $2.1 \mathrm{E}-14$ \\
\hline $7.1 \mathrm{E}-15$ \\
\hline
\end{tabular}

$\mathrm{DF}(\mathrm{rem} / \mathrm{pC} \mathrm{i})(\mathrm{b})$

$3.1 \mathrm{E}-16$

$3.1 \mathrm{E}-16$

$5.5 \mathrm{E}-17$

$7.4 \mathrm{E}-17$

8. $3 \mathrm{E}-14$

$9.7 \mathrm{E}-16$

$9.7 \mathrm{E}-16$

$3.3 \mathrm{E}-16$

(a) From Area Correction or Availability Worksheet.

(b) Calculated as Item 5 times Column 7. 


\section{Form E--Dose Variance [Var( $\left.O_{h}\right)$ l] Calculation Horksheet for Stratum h}

1. Facility and Stratum: 115D/DR - DR Tunnel - Agrícultural Scenario

2. Preparer's Name: GF Piepel. 3. Date Prepared: $6 / 25 / 86$ 4. Stratum Mass $\left(m_{h}\right): 4.46 E+6 g$ 5. Decay Tipe $(t): 100 \mathrm{yr}$

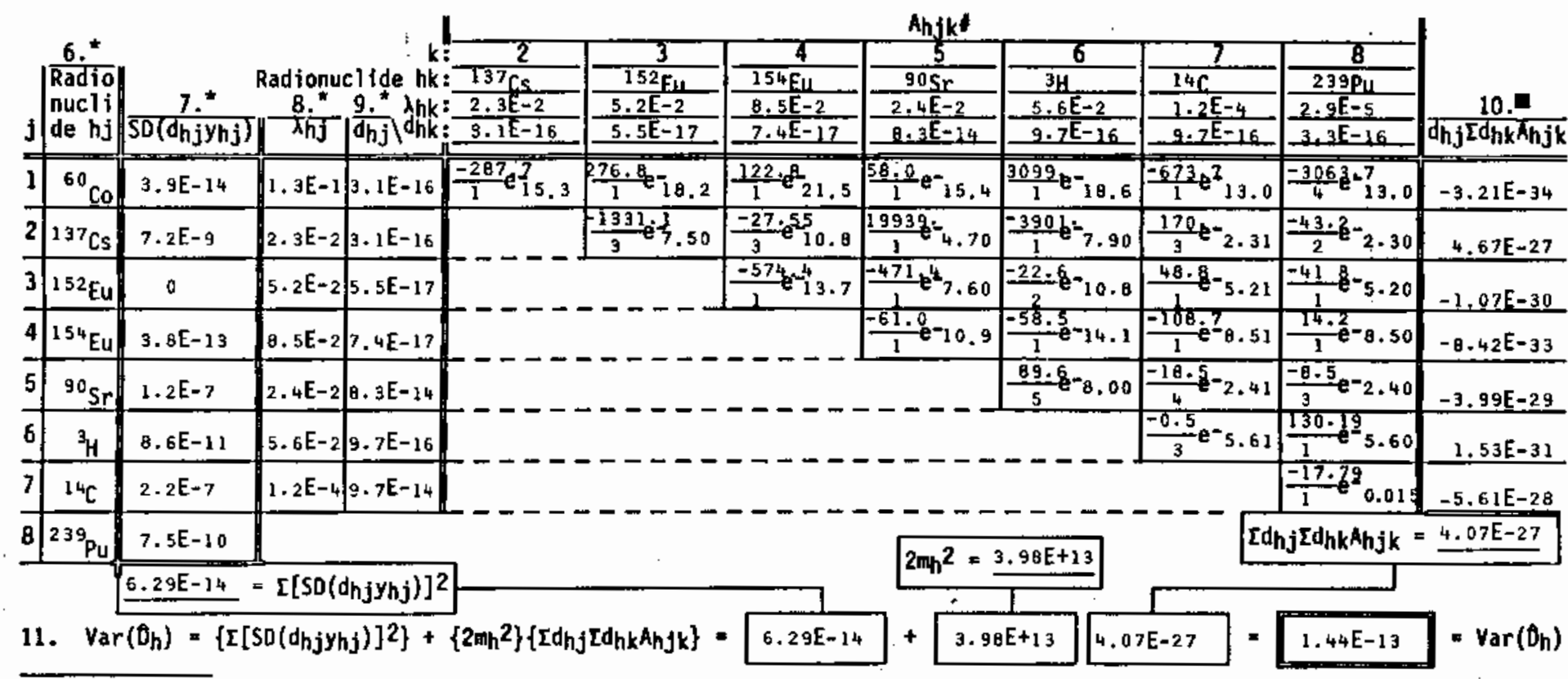

" Colum 6 [Radionuclide $j$ and $k$ ]--from Form $A$, Col. 4. Anjk $=\frac{\hat{\sigma}_{h j k}}{n h j k} e^{-\theta}$, where $\hat{\sigma}_{\mathrm{hjk}}$ is frow Form B, Col. 10 , Column 7 [SD (dhjyhj)]--from Form D, Col. 9.

Column 8 Xhj and $\lambda_{h k}$ ]-- from Table 5.3.

column 9 [ dhj and $d_{h k}$ ]--from Form D, Col. .7.

nhjke is from Form $B$, Col. 11; and

- Column 10--calculated as dhjidhk ${ }^{A} h j k$. 
Forn D - Stratue Dose Caleulation Morksheet

1. Facility/Scenario and Stratun: 115 D/DR - DR Tunnol, Agricultural Scenario

2. Proparer's Name: G. F. Piopel

3. Date Propared: $6 / 26 / 86$

4. Sadionuclide 6. Source

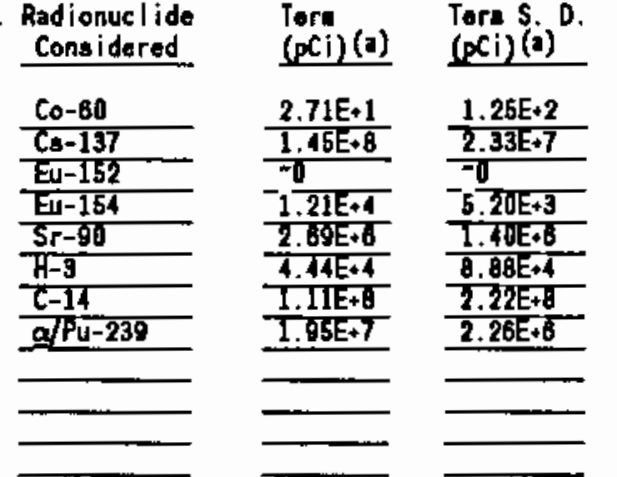

11. Variance of Estimatod Dose (ree/yr) ${ }^{(f)}$ :

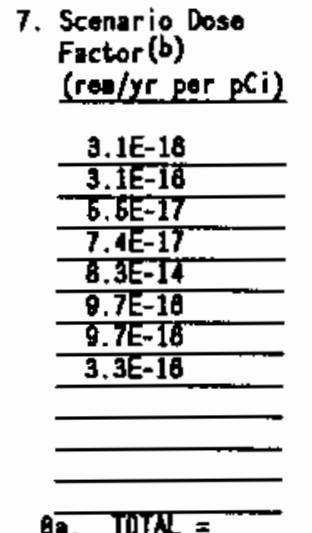

8. TOTR =
B. Estinated Dose (c) (re: $/ y r)$

9. S. D. of 10. Estinatod Dose(d) $80 \leqslant$ UCL. Dose(c) (rem/yr) $\frac{80 \times \text { UCL Dose }(e)}{\text { (ree/yr) }}$

$\frac{8.4 E-15}{\text { T.5E-8 }}$ T. -. UE-13 $2.3 \mathrm{E}-7 \mathrm{~V}$ 4.JE-11 6.4E-8

7. BE-10

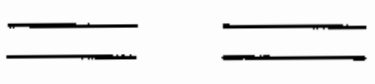

3.8E-7
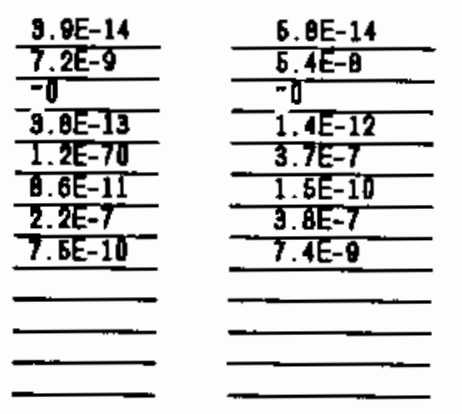

1. 4E-13

(a) Fran Forn $\mathrm{B}$ - Source Tora Torksheet (coluan 10 or 12), for $T=$

years.

(b) Fron Forn C - Availability, Forn F - Arez, Forn G - Depth, or Fore H - Hass Correction Vorksheets, as appropriate

(c) Calculate as the product of Colunns 5 and 7 .

(d) Calculate as the product of Coluans 8 and 7 .

(o) Calculate as (Coluan 8) - z1-a (Coluan 8), there z1-a is chasen to correspend with the desired confidence lavel froe Tablo 5.5.

(f) Caleulato using Proceduro 3.2.2, Columens 7, 9, and Coluns 8, 9, 10, and 11 from form A - Suneary Statistics lorksheet on Fora $E$ (Dose Variance Calculation Worksheot) 
Fore A - Sumary Statistics Table - Estimatod Leans, Standard Deviations, and Covariances per Stratue

1. Facility and Stratua: 115 O/OR - Sall portion of Oryer Roon (1 (Labeled as observation Mumber 16, Roon DR1 in Table A.1)

2. Proparer's Nano: O.F. Piepel

5. Lеgan 6. S. D.

4. Radionuclide
Considered
$(p C i / g)$ ohi $(p C i / g)$

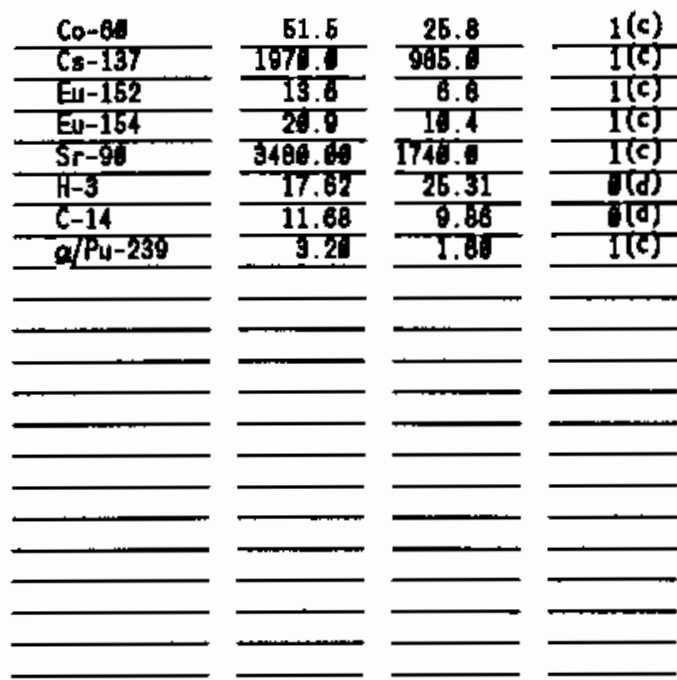

(a) Note: CoTunns 8-11 vill be wuch longer than 4-7.

Counents:

(b) Insufficient data to estimato covarionce. Values given we coaputed by taking into account other aspecte of the data. This was done to couplete this exanplo and is not recommended as general practice. For $n_{h i j} \leq 2$, use nhij=1 in any conputations requiring the values.

(c) Values frow the one sample are entered as moans, and assunes $\hat{o} / x^{-}=.5$; for oxasplo only.

(d) Hoans and S.D. based on four available data points in the tholo building.
9. Dato Propared: $0 / 25 / 80$

B. Nuclide $i(a)$ 9. Nuelide $j(0)$

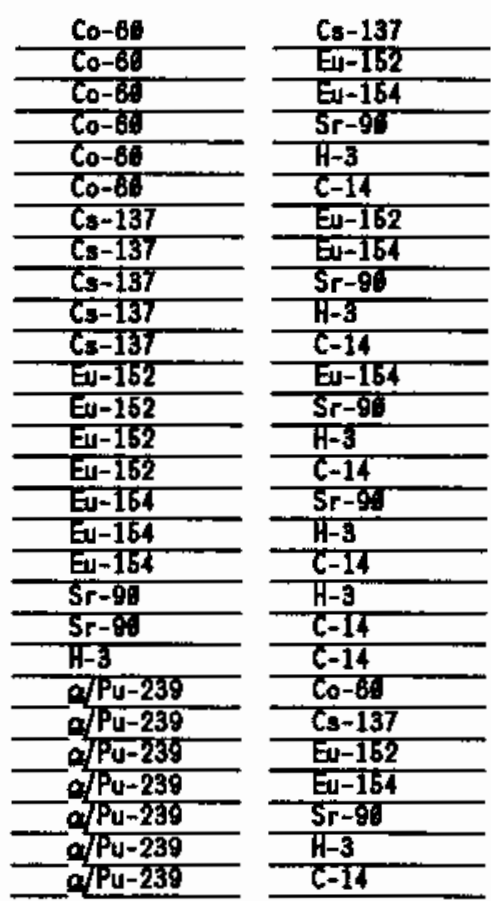

Nuctidea are Analyzed

(onij) (s)

(nhij)
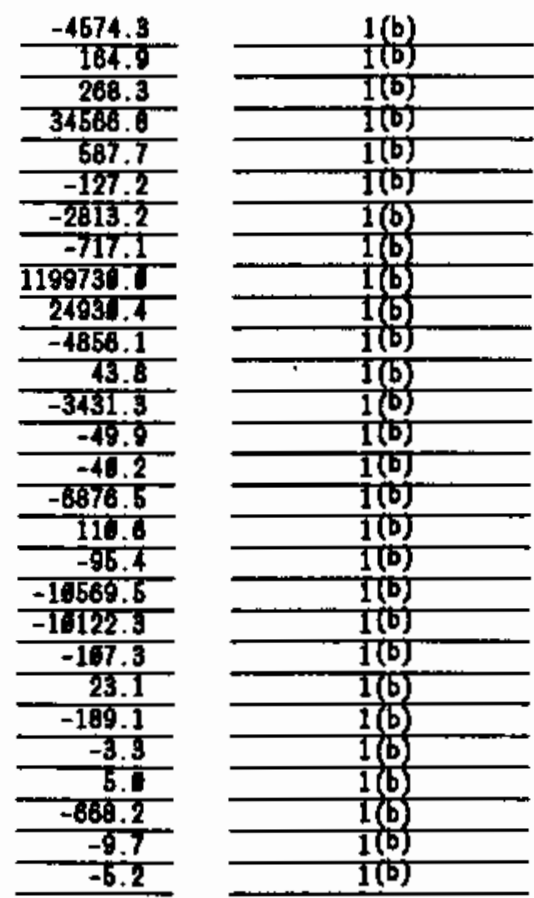


\section{Forn B - Source-Torn Worksheet}

1. Facility/Scenario and Stratum: 115 D/DR-DR - Residential Hone Gorden Sconario - Seall Portion of Ory Roon \$1

2. Preparer's Hane: G. F. Piepel

3. Date Prepared: $0 / 26 / 88$

4. Stratue Hass ${ }^{(a)}$ (grass): $8.3 E+4$ (o)

5. Nuaber of Years of Decay: $100(t)$ centration centration

6. Radionucl ide in Stratua, Considered (pci/g) (b) S. D. (b) 51.5 ohi ohi

\section{Nunber of} Sanplos in Stratua nhi (b)

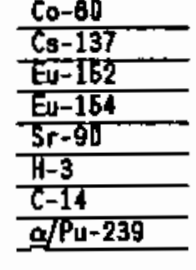

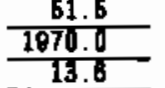

$$
\begin{array}{r}
13.6 \\
20.0
\end{array}
$$$$
20.8
$$$$
\frac{3480.0}{1762.0}
$$$$
\frac{1762.0}{11.68}
$$$$
\frac{11.86}{3.20}
$$
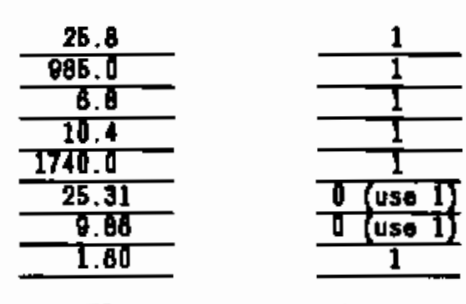

\begin{tabular}{l} 
10. Source \\
Tort \\
thi (d) \\
$4.29 E+8$ \\
$\frac{1.84 E+8}{1.15 E+6}$ \\
$\frac{1.74 E+6}{2.80 E+8}$ \\
$\frac{1.97 E+6}{2.73 E+5}$ \\
\hline $2.86 E+6$ \\
\hline
\end{tabular}
11. S. D

$2.15 E+6$

$8.20 E+7$

$\frac{1.66 E+5}{B .65+5}$

$8.66 E+6$

$\frac{1.46 E+8}{2.11 E+8}$

$\frac{2.11 E+\theta}{8.21 E+5}$

$1.33 E+1$
12. Decayed

\begin{tabular}{|c|c|c|}
\hline $\begin{array}{l}\text { Source } \\
\text { Torn } \\
\text { (pCi)(o) }\end{array}$ & 13. & $\begin{array}{l}\text { Decayed } \\
\text { S. D } \\
\text { thi }(f)\end{array}$ \\
\hline$\frac{9.71 \mathrm{E}+0}{1.64 \mathrm{E}+7}$ & & \\
\hline 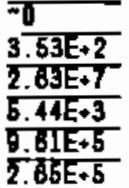 & & $\frac{\frac{1.78 E+2}{1.32 E+7}}{\frac{7.01 E+3}{8.11 E+6}} \frac{1.315+5}{1.33 E}$ \\
\hline
\end{tabular}

(a) Strata are definod to consist only of contaninated material.

(b) Copy froa Fora A - Sumary Statistica Table (Table 5.2.1).

(c) Calculate as Itea 4 times Itea 7.

(d) S. D. $\left(y_{h i}\right)=\left(\frac{h_{h}^{2}}{n_{h i}}\right)^{1 / 2}$

(6) Calculate as Iten 10 tines o- $\lambda_{i} t$ where $\lambda_{i}=$ decay constent for radionuclide $i$ (froe Table 5.2 .3 ) and $t=$ number of years of decay

(f) Calculato as Itom 11 tines e- $\lambda_{i} t$ shero $\lambda_{i}=$ decay constant for radionuclide $i$ (fron Table 5.2.3) and $t=$ nuaber of yoars of decay (Ites 5) 


\section{Forn C - Availability Correction Dorkshoet}

1. Facility/Sconario and Stratua: 116 D/DR - Rosidential-Hone Garden Scenario, Small Portion of Dryer Roou /1

2. Preparor's Nano: G. F. Piopel

3. Date Proparod: 8/26/86

B. Unnodified Dose Factors(b)

4. Radionuclide Considered

\section{Co-60}

$-\frac{c 0-60}{3-137}$

EN-152 Ea-164 $\frac{\mathrm{Sr}-96}{\mathrm{H}-3}$

\section{. Reduction} Factor (a) (rea/yr per pCi) (rea/yr per pCi)

\section{Corrected Dose Faclors(c) a. Inhalation 7b. Ingestion} (ron/yr per pCi) (rou/yr per pCi)

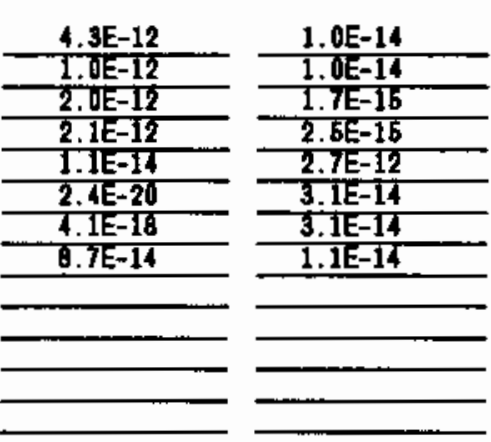

8. Residential/HoneGarden (d) Scenario Dose Faclors (ren/yr per pCi)

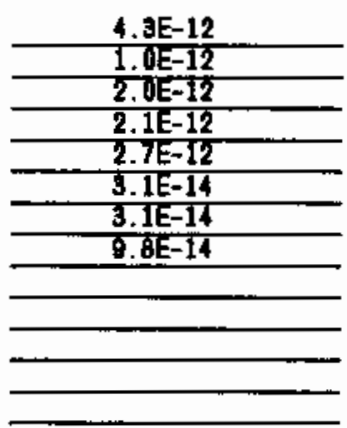

(a) $R=1.0$ for radionuclides not conteined in activated eotalo. $\mathrm{PF}=2 \mathrm{t}$ (corrosion rate $\mathrm{ca} / \mathrm{yr}$ )/(thickness in $\mathrm{ca}$ ).

(b) Fron Table 2.2 .

(c) Calculated as the product of coluns 5 and 8 , by radionuc lide.

(d) Conplete this coluan only for the Residential/Hone Garden scenario. The scenario dose factore are calculated as Coluan 7 a plus Coluan $7 \mathrm{~b}$. 


\section{Form E--Dose Variance [Var( $\left.Q_{h}\right)$ ] Calculation Worksheet for Stratun $h$}

1. Facility and Stratum: 1150/DR - Small portion of Dryer Room $n$ - Residential Home

2. Preparer's Hame: GF Piepel 3. Date Prepared: $6 / 26 / 86$ 4. Stratum Mass $\left(m_{h}\right): 8.3 E+49$ 5. Decay Time $(t): 100 \mathrm{yr}$

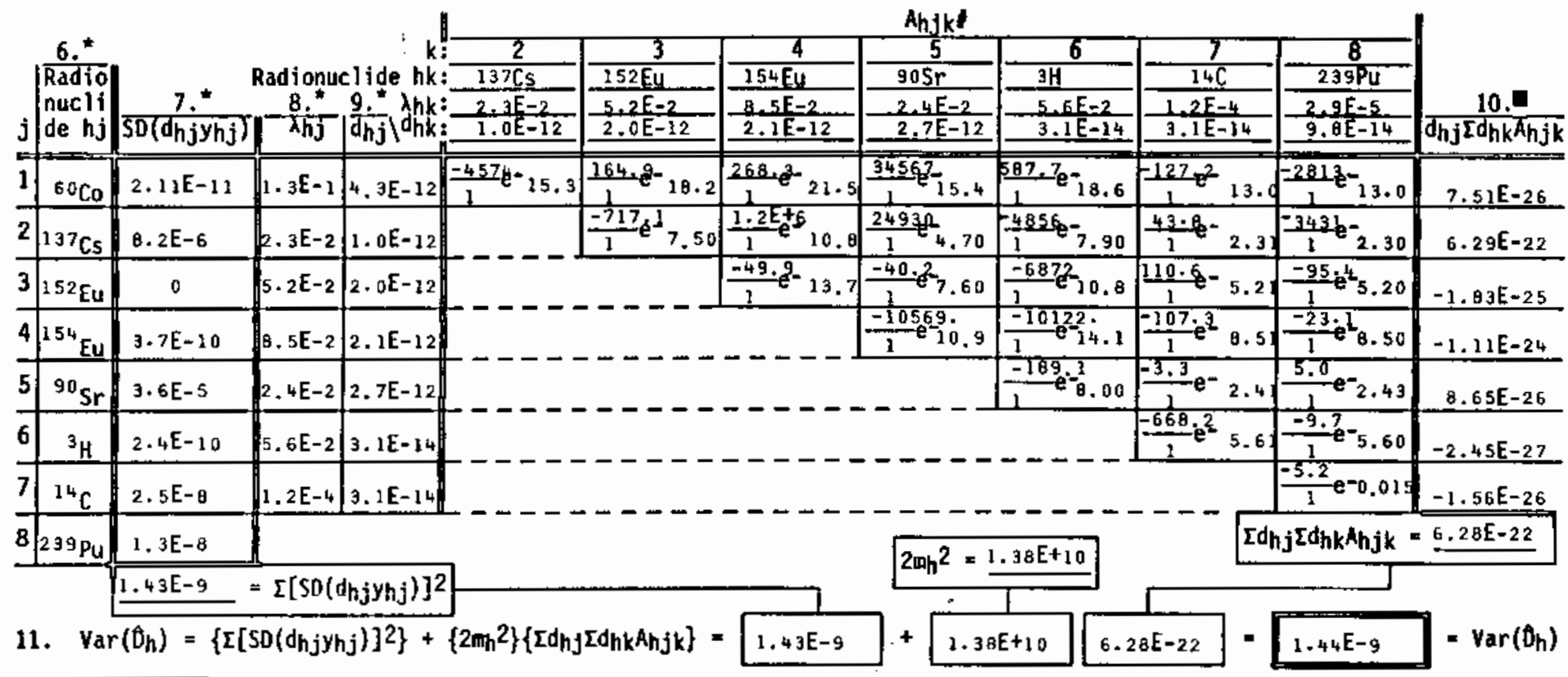

" Column 6 [Radionuclide $J$ and $k$ ]--from Form $A$, Col. 4. Column 7 [SO(dhjybj)]--from Form D, Col. 9.

Column 8 ihj and $\left.x_{h k}\right]--$ from Table 5.3

column $9[\mathrm{dhj}$ and dhk $\mathrm{d}$--from form $\mathrm{D}$, Col. 7.
- Ahjk $=\frac{\hat{\sigma}_{h j k}-\theta}{n_{h j k}}$, where $\hat{\sigma}_{h j k}$ is from Fon B, Col. 10 nhjk is from Forn B, Col. 11, and

- Column 10--calculated as $\theta_{h j}\left(\lambda_{h k}\right) t$. 
Forn D - Stratun Dose Calculation Horksheet

1. Facility/Scenario and Stratun: 115 D/OR - Rosidential-Home Garden Scenario - Seall Portion of Dryor Roon l1

2. Proparer's Hano: O. F. Piepol

3. Date Prepared: B/2B/BB

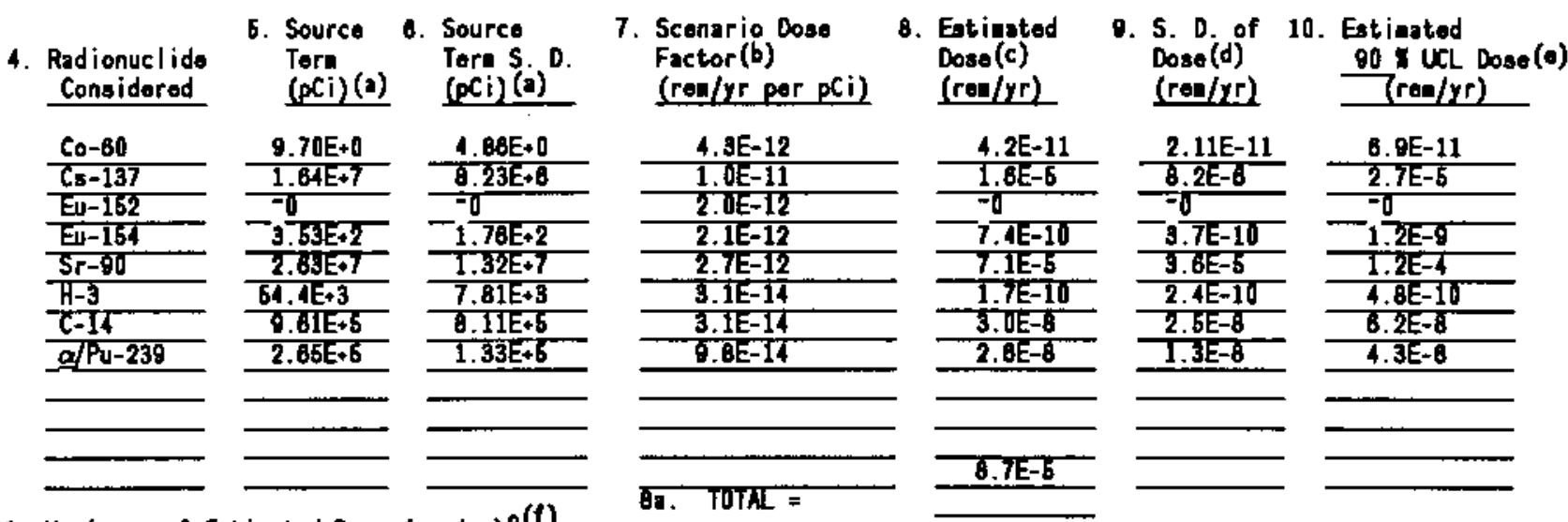

11. Variance of Estimatod Dose $(\mathrm{rew} / \mathrm{yr})^{2(f)}$ :

$1.40 E-9$

(a) Fron Forn B - Source Tere Worksheet (coluen 10 or 12), for $T=100$ years.

(b) Fron Forn C - Availability, Forn F - Area, Forn $Q$ - Depth, or ForE H- Hess Corroction Dorkshoets, as appropriate.

(c) Calculate as the product of Coluns 5 and 7.

(d) Calculate as the product of Coluans $B$ and 7

(o) Calculate as (Coluan 8) + 21-a (Coluen 9), there r1-a is chosen to correspond with the desired confidence lovel from Table 6.6.

(f) Calculate using Procedure 3.2.2, Columns 7, 0, and Coluens 8, 0, 10, and 11 froe Fora A - Sumary Statistics Torksheet on Fora E (Dose Variance Caleulation Terksheet). 
Forn A - Sunnary Stat istics Table - Estinated Heans, Standard Deviations, and Covar iances per Stratun

1. Facility and Stratus: 1170 Stratua A (Inlet Duct, A Filter Coll, A Outlot Seal Pit) - Labolod Room ID, AFC, AOSP in Tablo A.4)

2. Preparer's Nane: G. F. Piepel 3. Dato Prepared: 6/25/88

\section{Hean 6. S. D.}

4. Radionuclide

$$
\bar{x}_{h i} \text { ohi }
$$
Considered
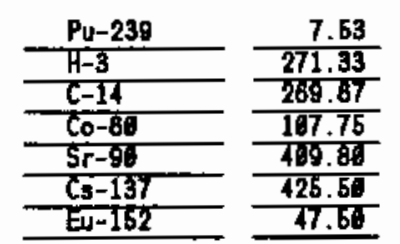

\begin{tabular}{l}
$\frac{7.63}{271.33}$ \\
$\frac{269.67}{107.75}$ \\
$\frac{199.86}{25.58}$ \\
\hline 17.58
\end{tabular} 47.68
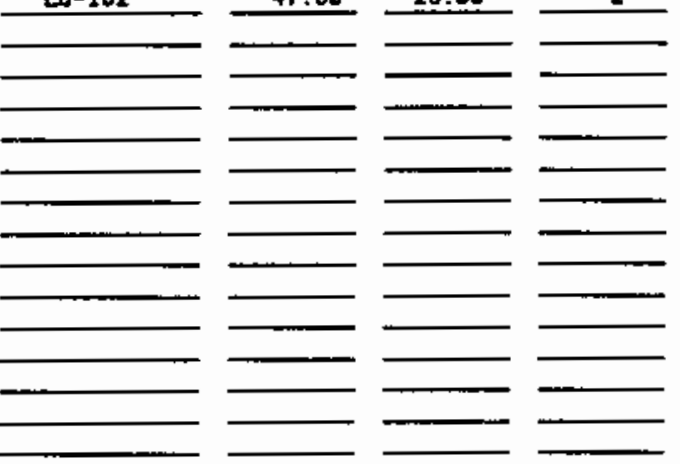

(a) Noto: Colunns 8-11 vill be nuch

Connonts: longer then 4-7.

(b) Insufficient data to ostinate covarianco. Values given were conputed by taking into aecount other aspects of the data. This was done to couplete this oxauple and is not reconmonded as general practice. For nhi $\leq 2$, use nh $\mathrm{j}=1$ in any conputations requiring the values.
11. Number of Samples for which both 16. Covariance Nuclides aro Analyzed 8. Muclide $i(a)$ 9. Nuclide $j(0)$ 10. Corariance (ohij)

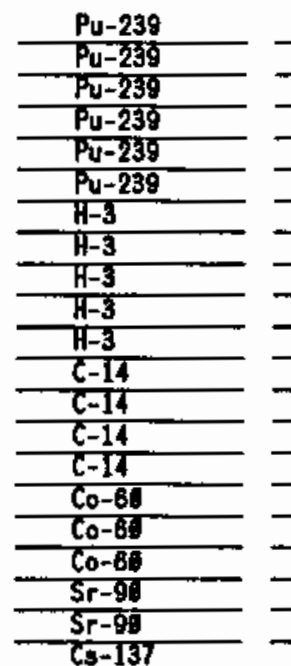

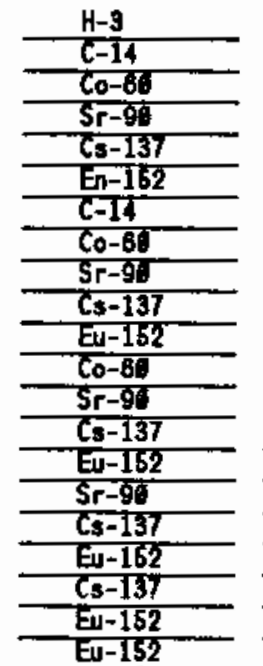
$\frac{1271.67}{838.83}$ $\frac{838.83}{235.12}$ 1537.65 96.81 97.29 20103.6 $-\frac{29463.6}{82391.7}$ 82331.7 167602.9 8515.7 22832.3 62284.8 141112.8 $\frac{6541.3}{18227.7}$ $\frac{18227.7}{40624.7}$ 40024.7 1883.2 119417.9 5766.

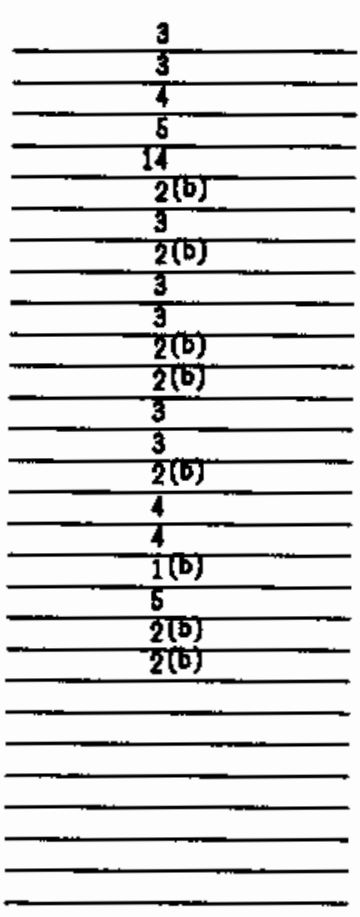




\section{Forn B - Source-Tors Porksheet}

1. Facility/Scenario and Stratue: 117 D - Stratun B, Agricultural Sconario

2. Preparer's Hane: G. F. Piepel

3. Date Prepared: $6 / 26 / 06$

4. Stratum Lass (a) (grans): $8.77 \mathrm{E}+5$ (0)

6. Nubber of Years of Decay: 100 ( $t)$

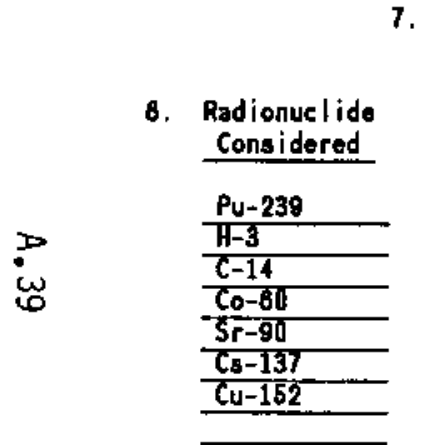

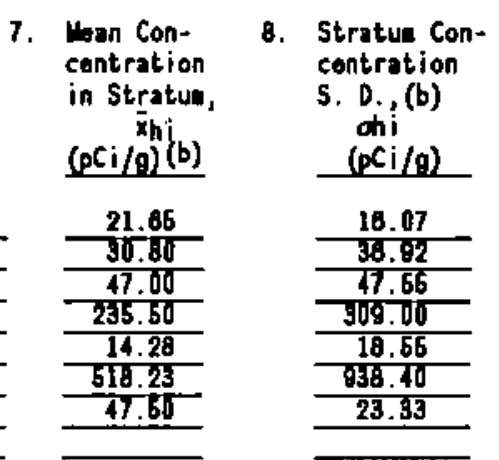

9. Number of Sanples in Stratun nhi (b)

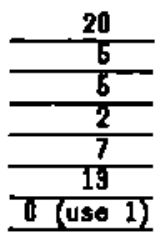

10. Source Tern Yhi (d)

$\frac{1.00 E+7}{2.70 E+7}$ 2.70E+7

2.07E+8

1.20E+ $4.17 \mathrm{E}+7$ 11. 5.0 .
Yhi $\underline{\text { (d) }}$

3.15E +6

I. $16 E+7$

$1.66 \mathrm{E}+1$

$1.92 \mathrm{E}+$

$6.15 E \cdot 6$

$2.28 E+$
12. Decayod

\begin{tabular}{|c|c|c|}
\hline $\begin{array}{l}\text { Source } \\
\text { Tern } \\
\text { (pci) (e) }\end{array}$ & 13. & $\begin{array}{l}\text { Decayec } \\
\text { S. D. } \\
\text { Yhi (f) }\end{array}$ \\
\hline 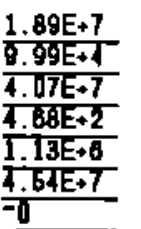 & & $\begin{array}{l}\frac{3.14 E+6}{5.37 E+4} \\
\frac{1.84 E+7}{1.34 E+2} \\
\frac{6.58 E+6}{2.28 E+7} \\
-0.0\end{array}$ \\
\hline
\end{tabular}

(a) Strata aro dofinod to consist only of contaninatod matorial.

(b) Copy fron Fore A - Summary Statistics Tablo.

(c) Calculate as Iten 4 tines Iten 7.

(d) S. D. $\left(y_{h i}\right)=\left(\frac{n_{h}^{2}}{n_{h i}}\right)^{1 / 2}$

(o) Calculate as Iten 10 tines e- $\lambda_{i} t$ where $\lambda_{i}=$ decay constant for radionuclide $i$ (fron Table 6.2 .3 ) and $t=$ number of yeare of decay

(f) Calculato as Iten 11 tines e- $\lambda_{i} t$ thero $\lambda_{i}=$ decay constent for radionuclide $i$ (fron Table 6.2.3) and $t=$ number of yoars of docay
(Ites 5). (Ites 5). 
TABLE 5.4.3. Depth Correction Worksheet

1. Facility: 117 D - Stratum A, Agricultural Scenario

2. Preparer's Name: G. F. Piepel

3. Date Prepared: 6/26/86

4. Depth of Clean overburden $6.7 \mathrm{~m}$.

5. Calculate depth correction factor (DCF) as DCF $=\mathrm{e}^{-0.92(\text { Depth) }}=2.1 \mathrm{E}-3$.

If Depth $>10$ meters DCF $=0.0$.

6. Radionuclide 7. Ingestion DF (rem/pCi) (a) Pu-239

\begin{tabular}{c}
$1.1 \mathrm{E}-14$ \\
\hline $3.1 \mathrm{E}-14$ \\
\hline $3.1 \mathrm{E}-14$ \\
\hline $1.0 \mathrm{E}-14$ \\
\hline $2.7 \mathrm{E}-12$ \\
\hline $1.0 \mathrm{E}-14$ \\
\hline $1.7 \mathrm{E}-15$ \\
\hline
\end{tabular}

H-3

C-14

Co-160

Sr-90

Cs-137

Eu-152

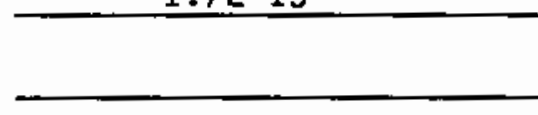

8. Corrected Ingestion $\mathrm{DF}(\mathrm{rem} / \mathrm{pCi})(\mathrm{b})$

2.3E-17

$6.5 \mathrm{E}-17$

$6.5 \mathrm{E}-17$

2.1E-17

$5.7 \mathrm{E}-15$

2.1E-17

$3.6 \mathrm{E}-18$

(a) From Area Correction or Availability Worksheet.

(b) Calculated as Item 5 times Column 7. 
Fon E--Dose Varfance [Var $\left(\theta_{h}\right)$ ] Calculation Horksheet for Stratum $h$

1. Facility and Stratua: 1170 Stratum A - Agricultural Scenario

2. Preparer's Mame: Gf Piepel 3. Date Prepared:6/26/86 4. Stratum Mass (mh): $8.19 E+5$ g 5. Decay Time $(t): 100$ yr

\begin{tabular}{|c|c|c|c|c|c|c|c|c|c|c|c|}
\hline & & & & & & & Ahjot & & & & \\
\hline 16. & & & & 2 & 3 & 4 & $\frac{5}{40 \pi}$ & 6 & 7 & 8 & \\
\hline $\mid \begin{array}{l}\text { Radio } \\
\text { nucli }\end{array}$ & & $\begin{array}{c}\text { Radionuk } \\
8 .{ }^{*}\end{array}$ & $\begin{array}{l}\text { Clide hk: } \\
\text { 9.* thk: }\end{array}$ & $\frac{9}{5.6 \mathrm{E}-2}$ & $\frac{14}{1.2 E-4}$ & $\frac{60 \mathrm{Co}}{1.3 \mathrm{E}-1}$ & $\frac{{ }^{00} \mathrm{Sr}}{2.4 \mathrm{E}-2}$ & $\frac{137 \mathrm{CS}}{2,3 \mathrm{E}-2}$ & $\frac{152 \mathrm{EU}}{5.2 \mathrm{E}-2}$ & & \\
\hline$f$ de $h j$ & $\overline{S D}\left(d_{h j} y_{h j}\right)$ & inj & ding d d & $6,5 \mathrm{E}-17$ & $6,5 E-17$ & $2.1 \mathrm{E}-17$ & $5,7 E-25$ & $2,1 \mathrm{E}-17$ & $3.6 E=18$ & & $d_{h j}\left[d_{h k^{\prime}} h_{h j k}\right.$ \\
\hline $1239 \mathrm{Pu}$ & 2. $0 \mathrm{EE}-11$ & $2.9 \mathrm{E}-5$ & $2.3 E-1$ & $\frac{127}{3} 8^{27} 50$ & $\frac{838.8}{3}-0.015$ & $\frac{265.42}{4}=13.0$ & $\frac{1537}{5} e^{25} \frac{25}{2} .40$ & $\frac{968}{14}-82.30$ & $\frac{97.29}{2}-e^{9} 5.20$ & $\Gamma^{--}$ & $4.06 \mathrm{E}-30$ \\
\hline $3 \mathrm{H}$ & $4.2 E-11$ & $5.6 \mathrm{E}-2$ & $6.5 E-17$ & & $\frac{100182}{3}-5.31$ & $\frac{29464}{2} e^{-}-18.3$ & $\frac{82332}{3}-7.70$ & $\frac{16750^{2}}{3} 7.60$ & $\frac{3515}{2} e^{7} 70.5$ & $-\mathrm{e}^{-}$ & $5.34 E-30$ \\
\hline $3 \mid 14 \mathrm{C}$ & 8. $5 \mathrm{E}-9$ & $|1.2 E-4|$ & 6. $5 E-17$ & & & $\frac{2632}{2}-13.0$ & $\frac{52285}{3} \div 2.41$ & $\frac{1411}{3} b^{2} z .31$ & $\frac{6541}{2} e^{\frac{3}{5}} \cdot 21$ & - & $6.96 E-28$ \\
\hline $460 \mathrm{Co}$ & $1.6 \mathrm{E}-15$ & $1.3 \mathrm{E}-1$ & 2. $|E-1|$ & & & & $\frac{10227}{4}+\frac{7}{15.4}$ & $\frac{40624}{4} e^{7}+15.3$ & $\frac{18 \theta^{3}}{1} \mathrm{e}_{1 \mathrm{~A} .2}^{2}$ & $\mathrm{e}^{-}$ & $1.13 \mathrm{E}-34$ \\
\hline $590 \mathrm{sr}$ & $4,7 E-8$ & $2.4 E-2$ & $5.7 \mathrm{E}-1 \mathrm{~S}$ & & & & & $\frac{199417}{5}-7.70$ & $\frac{5756}{2} e^{-9}=\frac{9}{7.60}$ & $\longrightarrow \mathrm{e}^{-}$ & $2.60 \mathrm{E}-29$ \\
\hline \begin{tabular}{|l|l|}
6 & $137 \mathrm{Cs}$ \\
\end{tabular} & 1. $9 \mathrm{E}-10$ & 2. $3 E-2 \mid$ & $2,1 E-1 \mid$ & & & & & & $\frac{9582}{2} e^{l} 7.50$ & $-e^{-}$ & $2.00 \mathrm{E}-34$ \\
\hline $7{ }^{152} \mathrm{Eu}$ & 0 & $5.2 \mathrm{E}-2$ & $3.6 \mathrm{E}-1 \mathrm{R}$ & & & & & & & e- & \\
\hline 8 & & & & & & & $a_{2}=$ & $34 \mathrm{~F}+12$ & & ${ }_{j}^{j}{ }^{2 d} h k^{A}{ }_{h j k}$ & $7.31 \mathrm{E}-28$ \\
\hline & $2.22 \mathrm{E}-15$ & $=\Sigma[S D(d)$ & $\left.\left(h j y y_{h j}\right)\right]^{2}$ & & & & & & & & \\
\hline 11. & $\left(\theta_{h}\right)=\{$ & ahs & ]$\left.^{2}\right\}+$ & & & $2.28 E-15$ & $+\mid 1.34$ & $E+12$ & $1 \mathrm{E}-28$ & 3. $3 E-15$ & $=\operatorname{Var}\left(\hat{\theta}_{h}\right)$ \\
\hline
\end{tabular}

Column 6 [Radionuclide $j$ and $k$ ]--from Form
Column 7 [SD (dhjyhj)]--from Form D, Col. 9 .
Column 8 [ $\lambda_{h j}$ and $\lambda_{h k}$ ]--from Table 5.3 .

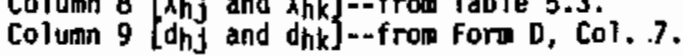

- Ahjk $=\frac{\hat{\sigma}_{h j k}}{n_{h j k}} e^{-\theta}$, where $\hat{\sigma}_{h j k}$ is from Form 8, col. 10, nhjk is from Form B, Col. 11, and

- Coluan 10--calculated as dhj ${ }^{2} d_{h k}{ }^{+} h j k$. 
1. Facifity/Scenario and Stratun: 117 Stratue $A$, Agricultural Sconario

2. Preparor's Nawo: G. F. Piopol

3. Date Prepared: $6 / 26 / 80$

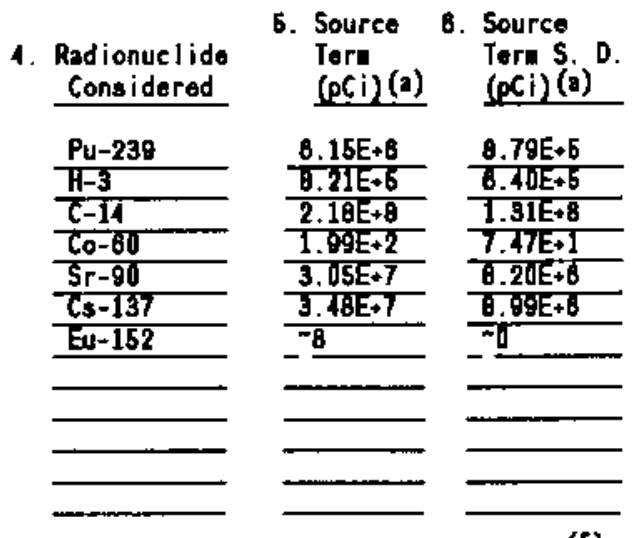

11. Variance of Eatiented Dose (ron/yr) ${ }^{(f)}$ :

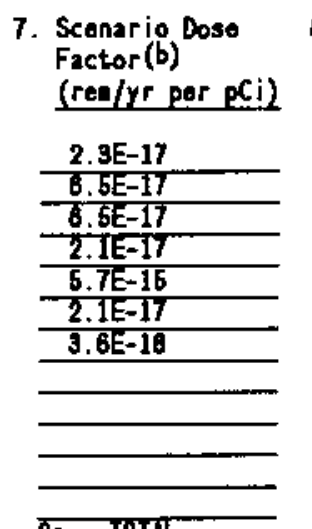

82. TOTKL $=$

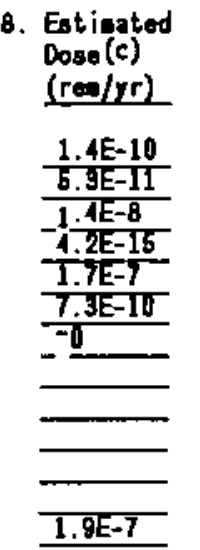

9. S. D. of 10. Estimated Dose(d) 90 X UCL Dose(e) (reo/yr) (row/yr)

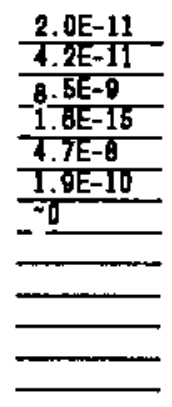

3. 3E-15

(a) Fron Forn $\mathrm{B}$ - Source Tera Iorksheet (coluan 10 or 12), for $\mathrm{T}=100$ years.

(b) Fron Forn C - Availability. Forn F - Area, Form G - Dopth, or Forn H- Wess Corroction Worksheets, as appropriate.

(c) Calculate as the product of Coluans 5 and 7

(d) Calculate as the product of Coluns 8 and 7 .

(o) Calculato as (Coluen 8) + z1-a (Coluan 9), there z1- $\alpha$ is chasen to correspond with the desired confidence lovel fros Table 5.6.

(f) Calculato using Procedure 3.2.2, Coluans 7, 9, and Coluans 8, 9, 10, and 11 fron Forn A - Sunary Stat istics Torksheat on Fore $E$ (Dose Variance Calculation Torksheat). 
Fora A - Sunary Statistica Table - Estiaatod Wans, Standard Doviations, and Covariances per Stratua

1. Facility and Stratua: 117D - Stratun B (Outlet Duct, A Inlet Send Pit, B Filter Coll, 8 Outlet Seal Pit) - Labeled as Roow OD, AISP, BISP, BFC, and BOSP in Tablo A.4)

2. Preparer's Hane: O. F. Piepel 3. Date Propared: 8/25/86

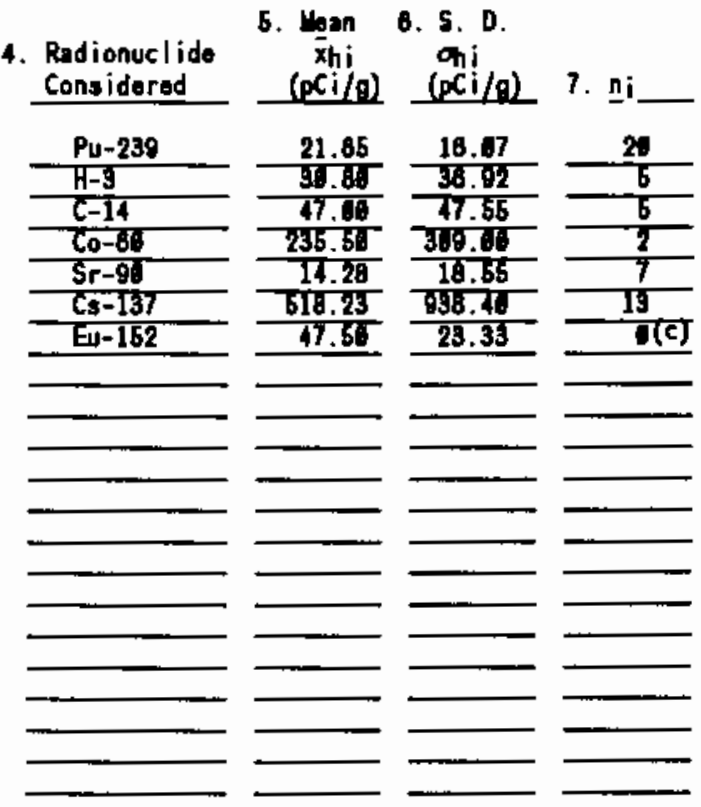

(a) Hote: Coluans 8-11 vill be wuch longer than 4-7.

Cosurente:

(b) Insufficient data to estinate coyariance. Values given wre cosputed by taking inte account other aspecte of the dats. This was done to couplete this exanple and is not recommended as general practice. For nhij $\leq 2$, use nhij=1 in any conputations requiring the values.

(c) In the absence of any data, the sano value for Stration a are used.
11. Nunber of Sanples for thich both 8. Nuclido $i(a)$ 9. Nuclide $i(a)$ 10. Covariance Nucl ides ara Analyzod

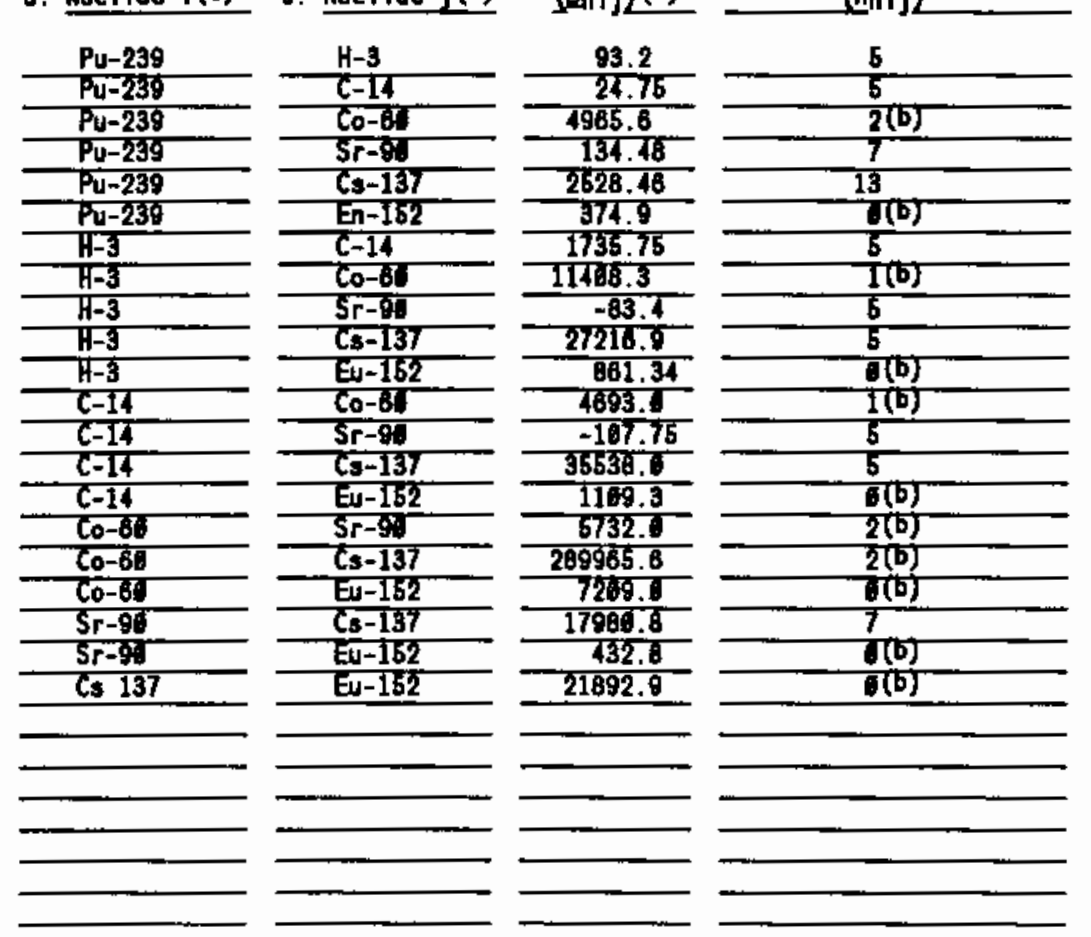




\section{Form B - Source-Ters Worksheet}

1. Faciliky/Scenario and Stratun: 117 D - Stratun B, Agricultural Sconario

2. Preparor's Mane: G. F. Piepol

3. Dato Proparod: $6 / 26 / 8 B$

1. Stratue Mass(a) (grans): $0.77 E+5$ (a)

5. Nubber of Years of Decay: 100 (t)

7. Wean Con- B. Stratua Con$\begin{array}{ll}\text { centration } & \text { contration } \\ \text { in Stratur, } & \text { S. D. (b) }\end{array}$

6. Radionuclide Considered in Strabur Consider (pCi/g) (b) S. D. bi (pi $\mathrm{b} / \mathrm{s})$ 21.65 $\begin{array}{r}31.60 \\ \hline 47.00 \\ \hline\end{array}$ 235.50 14.28 $\frac{14.28}{518.23}$ $\begin{array}{r}4.60 \\ \hline\end{array}$

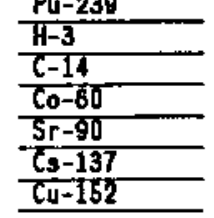

- Nubber of Saeples in Stratue nhi (b)

(a) Strata aro dofined to consiat only of contaninated eaterial.

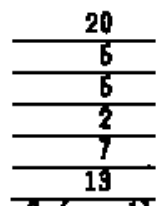

ర (Use 1)
10. Source Torm yhi (d) $1.00 \mathrm{E}+7$ 2.70E+7 T.T2E+7

2.07E+8

$1.26 \mathrm{E}+7$ $4.64 E+6$
11. 5. 0 . thi (d)

$3.15 E+6$ $\frac{3.15 E+6}{1.45 E+7}$ $1.66 \mathrm{E}+7$

$1.92 \mathrm{E}+6$

$6.16 E+6$ $2.28 E+6$
12. Docayed Source Torn (pci) (e)

13. Decayod

1.89E+7 $\quad 3.14 \mathrm{E}+8$
$8.99 \mathrm{E}+4 \quad$ 5. $37 \mathrm{E}+1$ T.07E+7 T. BAE+7 T.6BE+2 T.13E+6 $4.54 E+7$ $4.54 E+7$ II

(b) Copy fron Forn A - Sumary Statistics Tablo.

(c) Calculate as Item 4 tinos Iten 7.

(d) S. D. $\left(y_{h i}\right)=\left(\frac{\omega_{h i}^{2}}{n_{h i}}\right)^{1 / 2}$

(o) Calculate as Itee 10 tiees e- $\lambda_{i}{ }^{t}$ where $\lambda_{i}=$ decay constant for radionuclide $i$ (fron Table 5.2.3) and $t=$ nusber of years of decay

(f) Calculato as Iten 11 tieses o- $\lambda_{i} t$ there $\lambda_{i}=$ decay constant for radionuclide $i$ (fron Table 6.2 .3 ) and $k$ m nunber of years of decay (Iten 5). 


\section{Forn C - Ayailability Correction Dorksheot}

1. Facility/Scenario and Stratun: 1170 - Stratua B, Agricultural Sconario

2. Preparer's Mano: O. F. Piepel

3. Date Preparod: $6 / 28 / 88$

6. Unnodified Dose Factors(b)

4. Radionuclide Considered

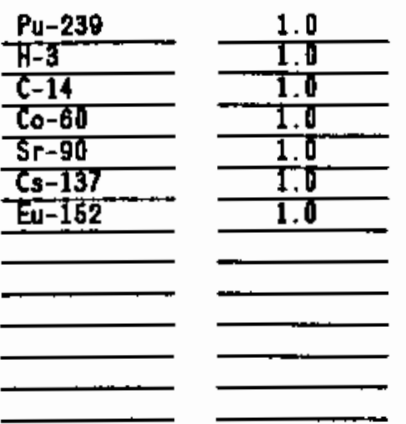
$\begin{array}{ll}\text { 6a. Inhalation } & \text { 6b. Ingestion } \\ \text { (rea/yr per } \mathrm{pCi} \text { ) } & \text { (ren/yr per } \mathrm{pCi})\end{array}$

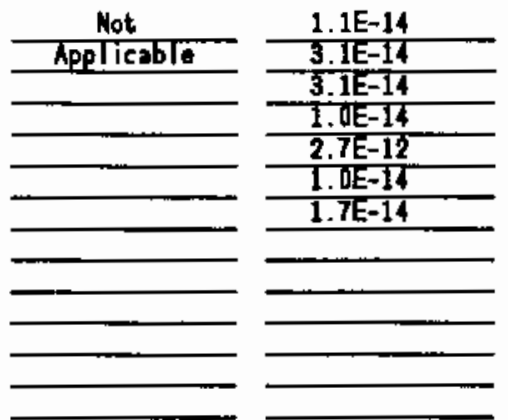

7. 7a. Thialation $7 \mathrm{~b}$. Ingestion (rom/yr per pCi) (row/yr per pCi)

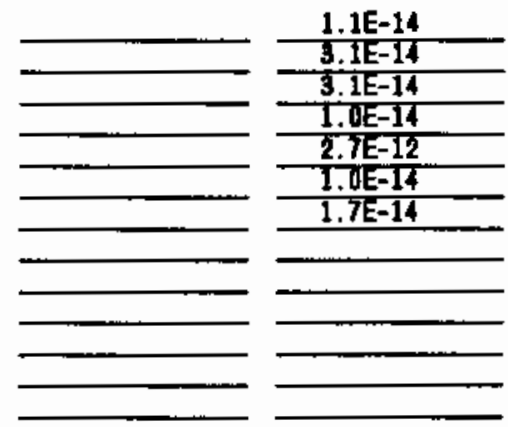

8. Residential/HoneGarden (a) Scenario Dose Factors (ren/yr per pci)

Not

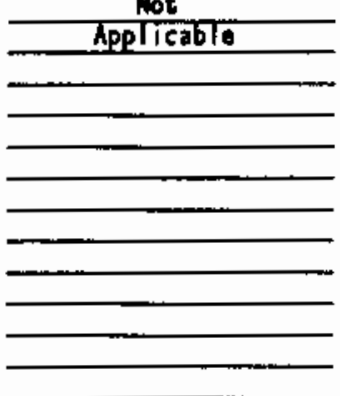

a) $\mathrm{NF}=1.6$ for radionuclides not contained in actirated watals. $\mathrm{BF}=2 \mathrm{l}$ (corrosion ralo $\mathrm{cm} / \mathrm{yr}$ )/(thickness in $\mathrm{cn}$ ).

(b) Fron Tablo 2.2.

(c) Calculated as the product of coluans 5 and 6 , by radionuclide.

(d) Coaplate this coluan only for the Residential/Hone Garden ecenario. The scenario dose factora are calculated as Coluan 7 a plus Coluan $7 b$. 


\section{Form G - Depth Correction Worksheet}

1. Facility: 117 D - Stratum B, Agricultural Scenario

2. Preparer's Name: G. F. Piepel

3. Date Prepared: $6 / 26 / 86$

4. Depth of Clean overburden $6.7 \mathrm{~m}$.

5. Calculate depth correction factor (OCF) as OCF $=\mathrm{e}^{-0.92(\text { Depth) }}=2.1 \mathrm{E}-3$.

If Depth $>10$ meters $D C F=0.0$.

6. Radionuclide 7. Ingestion $D F(\mathrm{rem} / \mathrm{pC} \mathrm{j})(\mathrm{a})$

Pu-239

$\mathrm{H}-3$

C-14

Co- 160

Sr-90

Cs -137

Eu-152

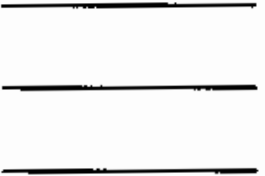

$1.1 \mathrm{E}-14$

\begin{tabular}{c}
\hline $3.1 \mathrm{E}-14$ \\
\hline $3.1 \mathrm{E}-14$ \\
\hline $1.0 \mathrm{E}-14$ \\
\hline $2.7 \mathrm{E}-12$ \\
\hline $1.0 \mathrm{E}-14$ \\
\hline $1.7 \mathrm{E}-14$ \\
\hline
\end{tabular}

$3.1 \mathrm{E}-14$
8. Corrected Ingestion $\mathrm{DF}(\mathrm{rem} / \mathrm{pCi})(\mathrm{b})$

2.3E-17

$6.5 \mathrm{E}-17$

6.5E-17

2.1E-17

5.7E-15

2.1E-17

$3.6 \mathrm{E}-17$

(a) From Area Correction or Availability Worksheet.

(b) Calculated as Item 5 times Column 7 . 


\section{Form E- -Dose Variance [Var(Ûh)] Calculation Worksheet for Stratum h}

1. Facility and Stratum: 1170 - Stratum B - Agricultural Scenario

2. Preparer's Name:GF Plepel 3. Date Prepared: 6/27/86 4. Stratum Mass (mh): $8.77 \mathrm{E}+5 \mathrm{~g}$ 5. Decay Tine (t): 100 yr

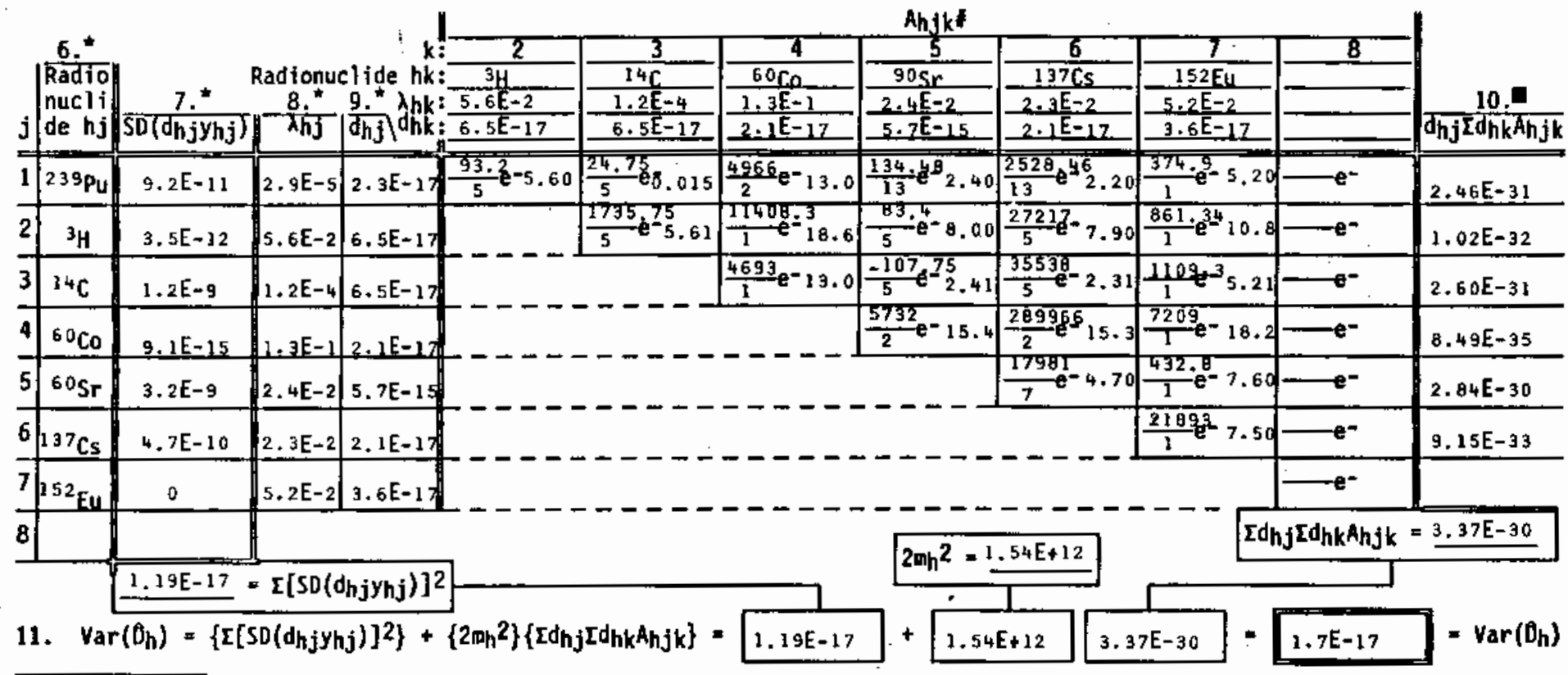

- Column 6 [Radionuelide $j$ and $k$ ]--fram form $A$, Col. 4. Columin 7 [SD(dhjyhj)]--from Form 0 , Col, 9.

Column 8 [ihj and $\left.x_{h k}\right]--$ from Table 5.3 .

Column 9 [dhj and dhk]--from Form 0 , Col. .7. - Ahjk $=\frac{\hat{\sigma}_{h j k}}{n h j k} e^{-\theta}$, where $\hat{o}_{h j k}$ is from Form B, Col. 10, $\theta=\left(\lambda_{h j}+\lambda_{h k}\right) t$.

- Column 10--calculated as $\mathrm{dhj}_{\mathrm{h}} \mathrm{dhk}_{\mathrm{h}}^{\mathrm{A} h \mathrm{hk}}$. 


\section{Forn D-Stratun Dose Calculation Worksheot}

1. Facility/Scenario and Stratue: 1170 Stratun B, Agricultural Sconario

2. Preparer's Hane: G. F. Piepel

3. Date Prepared: $6 / 27 / 86$

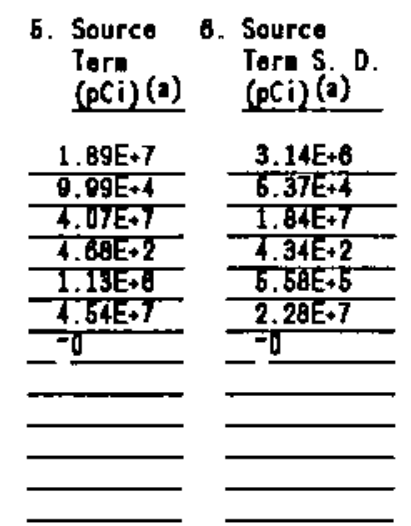

11. Variance of Estisated Dose $(\mathrm{rea} / \mathrm{yr})^{2^{(f)}}$ :

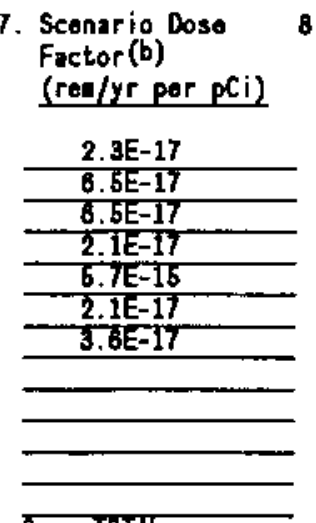

8. TUTRL =
8. Estiuated Dose(c) (realyr)

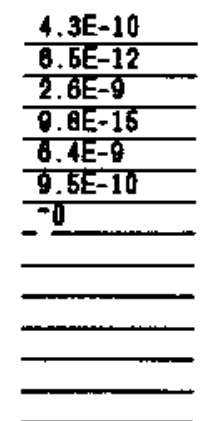

9. S. D. of 10. Eatinated Dose(d) $90 \times$ UCL Dose(o) (ren/yr) (ren/yr)

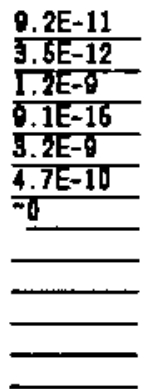

(restris

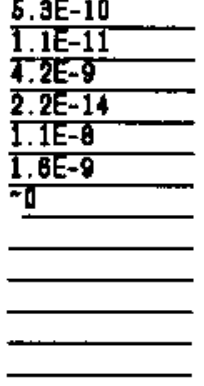

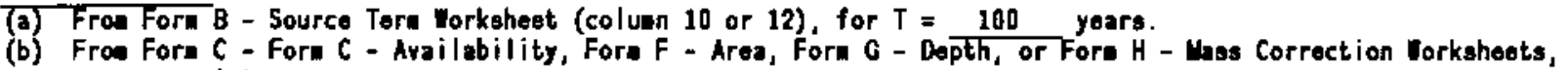

(c) Calculate as the product of Columes 5 and 7 .

(d) Calculate as the product of Coluans $B$ and 7

(e) Calculate as (Column 8) + z1- $\alpha$ (Column $\theta$ ), where z1-a is chosen to correspond with the desired confidence level fron Tablo 5.6.

(f) Calculate using Proceduro 3.2.2, Colums 7, 9, and Coluans 8, 9, 10, and 11 from Form A - Sumary Statistics Vorksheet on Forn $E$ (Dose Yariance Caleulation Worksheot). 


\section{Fom I - Final ARCL Worksheet - Summed Over All Strata}

1. Facility/Scenario: 115 D/DR and 1170 - Residential-Home Garden Scenario

2. Preparer's Name: G. F. Piepel

3. Date Prepared: $6 / 27 / 86$

4. Stratum or

Scenario

Considered (a)

1150/DR, Main

Floor and Basement

in $20 \times 10 \times 5 \mathrm{~m}$

Excavation

1150/OR, Small

Portion of Dryer

Room \#1
5. Total Dose per Stratum or Scenario (rem/yr) (b)

7.0E-5

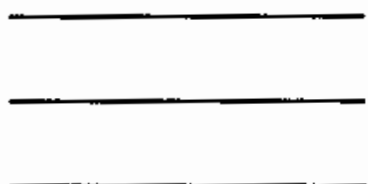

$$
8.7 \mathrm{E}-5
$$

$1.4 \mathrm{E}-9$
6. Variance of the Dose (c)

(rem/yr) ${ }^{2}$

$1.0 \mathrm{E}-10$
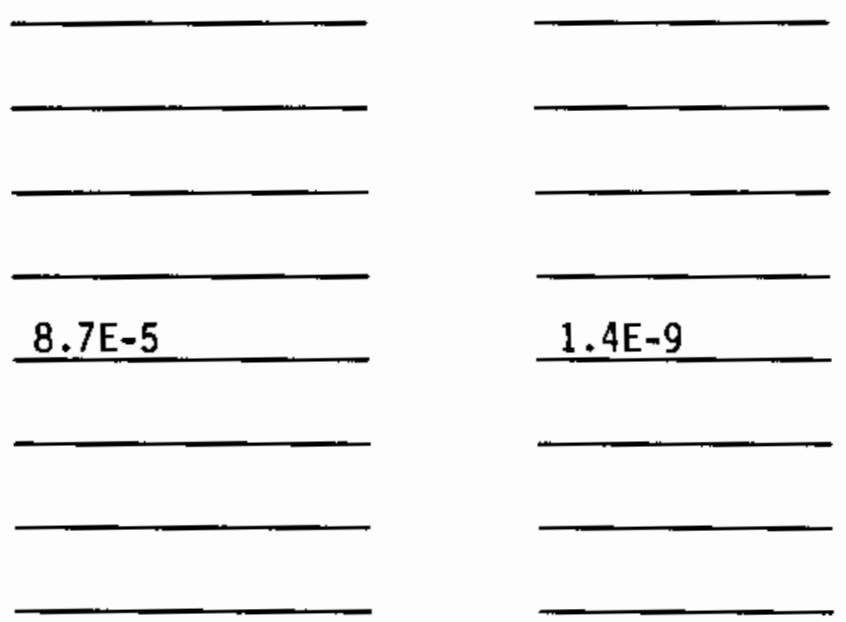

$5 \mathrm{a}=1.6 \mathrm{E}-4$

$6 \mathrm{a}=\underline{1.5 \mathrm{E}-9}$

7. $(6 \mathrm{a}) 1 / 2=S O\left[\hat{U}_{S}(\mathrm{t})\right]=3.9 \mathrm{E}-5$

8. $5 a+z_{1-\alpha}^{(d)} * 7=2.1 E-4$ $90 \div \mathrm{UCL})$

(a) Note: Forms A, B, C, and D are completed for each Stratum considered.

(b) From Item $8 b$ in Form 0 for each Stratum considered.

(c) From Item 11 in Form $D$ for each Stratum considered.

(d) Obtained from Table 5.5. 
Form I - Final ARCL Worksheet - Summed Over All Strata

1. Facility/Scenario: $115 \mathrm{D} / \mathrm{DR}$ and $117 \mathrm{D}$ - Agricultural Scenario

2. Preparer's Name: G. F. Piepel

3. Date Prepared: $6 / 27 / 86$

4. Stratum or

Scenario

Considered (a)

115D/DR, Balance

of Main Floor

and Basement

1150/DR-D Tunnel

$\underline{115 D / D R-D R \text { Tunnel }}$

1170 -Stratum A

117D-Stratum B

Room \#1
5. Total Dose per Stratum or Scenario $(\mathrm{rem} / \mathrm{yr})(\mathrm{b})$

$2.8 \mathrm{E}-6$

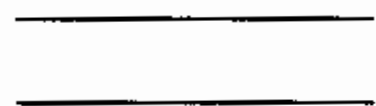

$1.5 \mathrm{E}-7$

1.6E-7

$1.9 \mathrm{E}-7$

$1.0 \mathrm{E}-8$

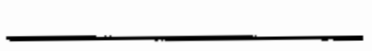

(TOTALS)

$$
5 \mathrm{a}=\underline{6.5 \mathrm{E}-6}
$$

7. $(6 a) 1 / 2=S D\left[\hat{D}_{S}(t)\right]=3.3 \mathrm{E}-6$

8. $5 a+z_{1-\alpha}^{(d)} * 7=1.1 E-5$
6. Variance of the Dose (c) $(\mathrm{rem} / \mathrm{yr})^{2}$

$8.9 E-13$

$1.0 \mathrm{E}-11$

1. $4 \mathrm{E}-13$

$3.3 \mathrm{E}-15$

1.7E-17

$6 a=1.1 E-11$

(a) Note: Forms A, B, C, and D are completed for each Stratum considered.

(b) From Item $8 \mathrm{~b}$ in Form $\mathrm{D}$ for each Stratum considered.

(c) From Item 11 in Form D for each Stratum considered.

(d) Obtained from Table 5.5. 


\section{Form I - Final ARCL Worksheet - Summed Over All Strata}

1. Facility/Scenario: 115 D/DR and 1170 - Residential-Home Garden and Agricultural Scenario

2. Preparer's Name: G. F. Piepel

3. Date Prepared: $6 / 27 / 86$

4. Stratum or Scenario Considered (a)

Res.-Home Garden

Agricultural

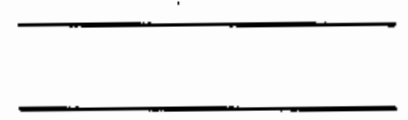

(TOTALS)
5. Total Dose per Stratum or Scenario (rem/yr) (b)

$1.6 \mathrm{E}-4$

$6.5 \mathrm{E}-6$
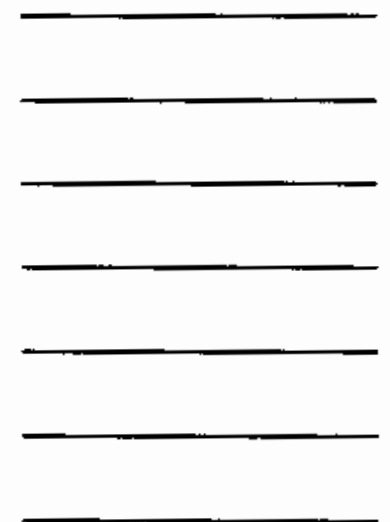

$$
5 \mathrm{a}=1.7 \mathrm{E}-4
$$

7. $(6 \mathrm{a}) 1 / 2=\mathrm{SD}[\mathrm{DS}(\mathrm{t})]=3.9 \mathrm{E}-5$

8. $5 a+z(d) * 7=2.2 E-4$

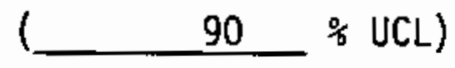
(a) Note: Forms A, B, C, and D are completed for each Stratum considered.
(b) From Item $8 b$ in Form $D$ for each Stratum considered.
(c) From Item 11 in Form $D$ for each Stratum considered.
(d) Obtained from Table $\mathbf{5 . 5}$. 
Form A - Sumary Statistics Tablo - Estinated Leans, Standard Deviations, and Covariancos por Stratua

1. Facility and Stratua: $115 \mathrm{D} / \mathrm{DR}$ Building/Pipes

2. Proparer's Mand: B. A. Napier

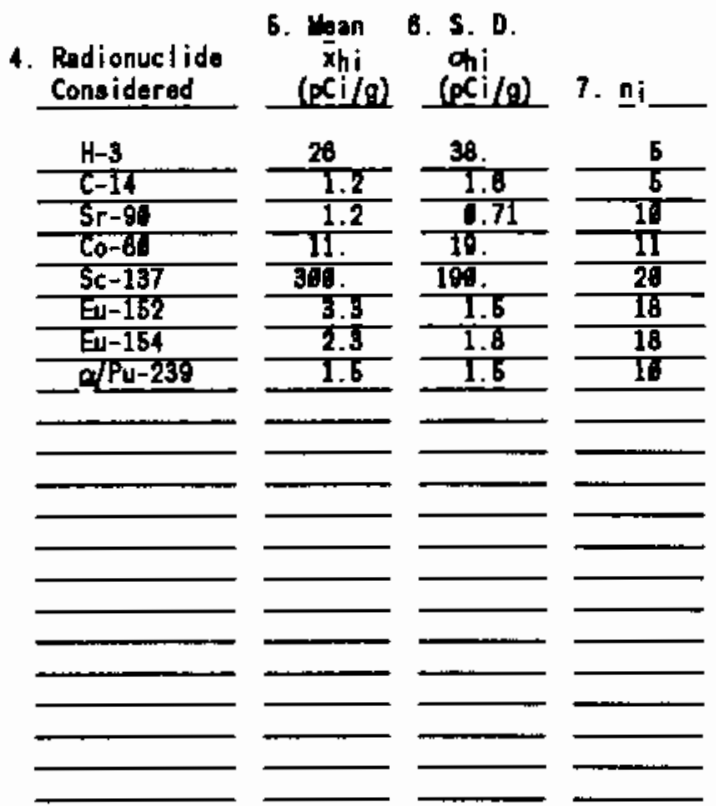

(a) Note: Colunns 8-11 iill be nuch

Conents :

(b) H-3 can be ignored for Resource Recycle Scenario since $D F=$
3. Date Propared: 6/25/88

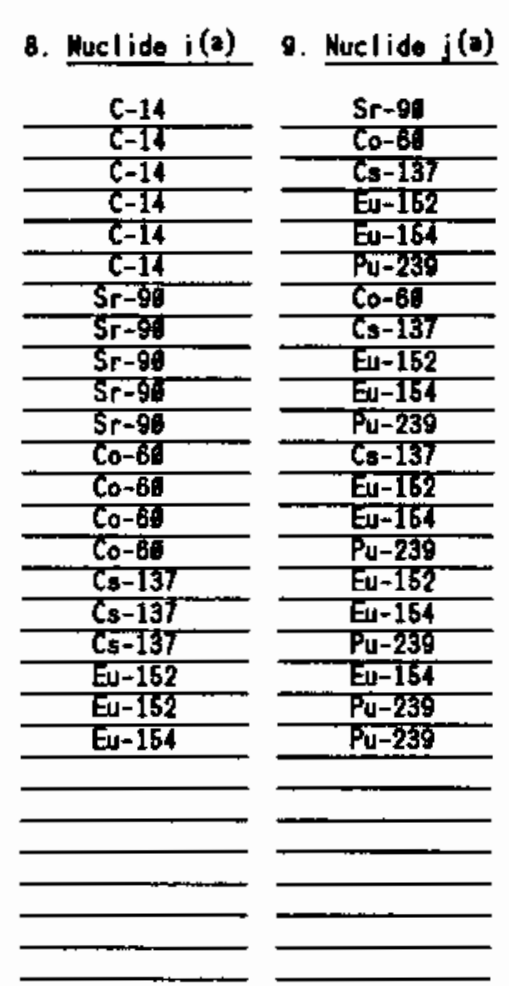

11. Nuabar of Samples for which both Nucl ides aro Analyzed - Covariance
(ohij)(a)

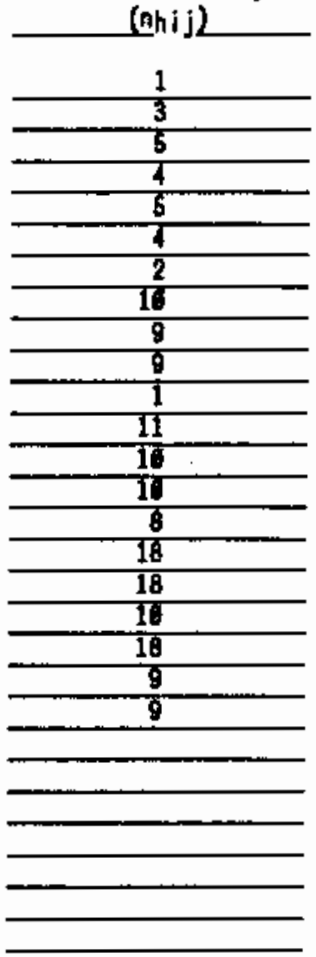


Fore B - Source-Tere Vorksheet

1. Facility/Scenario and Stratun: $115 \mathrm{D} / \mathrm{DR}$ Building/Pipes

2. Preparor's Nase: B. A. Napier

3. Date Prepared: $6 / 25 / 86$

1. Stratun Hass(a) (grans): 8.2BE+7g (n)

5. Nuaber of Yoars of Decay: 100 ( $t$ )

7. Wan Con- 8. Stratun Concentration centration

Radionuclide in Stratua, S. D., (b)

\begin{tabular}{|c|c|c|}
\hline $\begin{array}{l}\text { Radionuclide } \\
\text { Considered }\end{array}$ & $\begin{array}{r}x_{h} i_{(b)} \\
(p c i / g)(b) \\
\end{array}$ & $(\mathrm{pCi} / \mathrm{gi})$ \\
\hline$\frac{C-14}{5 r-96}$ & $-\frac{1.2}{1.2}$ & $\frac{1.6}{0.71}$ \\
\hline$C_{0-69}$ & 11. & 18. \\
\hline Cs-137 & 300. & 196. \\
\hline Eu-152 & 3.3 & 1.5 \\
\hline Eu-154 & 2.3 & 1.0 \\
\hline$P_{u}-235$ & 1.5 & 1.5 \\
\hline
\end{tabular}

9. Nuaber of Sanples

in Stratun

5

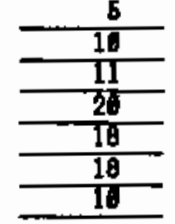

10. Source

$$
\begin{aligned}
& \text { Source } \\
& \text { Torn } \\
& \text { this }
\end{aligned}
$$

Yhi (d)

$\frac{8.9 \mathrm{E}+7}{9.9 \mathrm{E}+7}$

$\frac{9.9 E+7}{9.1 E+6}$

2.5E+10

$2.7 E+8$

$\frac{1.9 E+8}{1.2 E+8}$
12. Decayed

Source

Tore

(pci) (o)

13. Decayed

Shi

his

$\frac{9.0 \mathrm{E}+7}{9.0 \mathrm{E}+6} \quad \frac{5.0 \mathrm{E}+7}{1.7 \mathrm{E}+6}$

2.1E+3 T.1E+3

$2.5 E+9 \quad 3.6 E+8$

$\frac{1.6 \mathrm{E}+6}{1.6 \mathrm{E}+5}$

$\widehat{9 \mathrm{E}+1}$

$1.2 \mathrm{E}+8$

(a) Strata aro dofined to consist only of contan inatod aterial.

(b) Copy fron Foraa A - Sumary Statistics Table.

(c) Calculate as Item 4 tines Iten 7.

(d) S. D. $\left(y_{h i}\right)=\left(\frac{h_{h}^{2}}{n_{h i}}\right)^{1 / 2}$

(o) Calculate as Ited 10 thes o- $\lambda_{i}$ there $\lambda_{i}$ = decay constant for radionuclide $i$ (fron Tablo 5.2.3) and $t=$ nunber of years of decay (Iten 5).

(f) Calculate as Itea 11 tines o- $\lambda_{j} t$ where $\lambda_{i}=$ decay constant for radionuclide $i$ (from Table 5.2 .3 ) and $t=$ nubber of yeara of decay (Iten 5). 
Form H - Mass Correction Worksheet

1. Facility: $115 \mathrm{D} / \mathrm{DR}$ Building, Pipes

2. Preparer's Name: B. A. Napier

3. Date Prepared: 6/25/86

4. Mass of contaminated metal, 82.6 $\mathrm{Mg}$.

5. Calculate mass correction factor (MCF) as

$$
\text { MCF }=\text { Item } 4 / 200=\underline{0.41}
$$

6. Radionuclide 7. Recycle DF $(r e m / y r / p C i)(a) \quad$ DF $(r e m / y r / p C i)(b)$

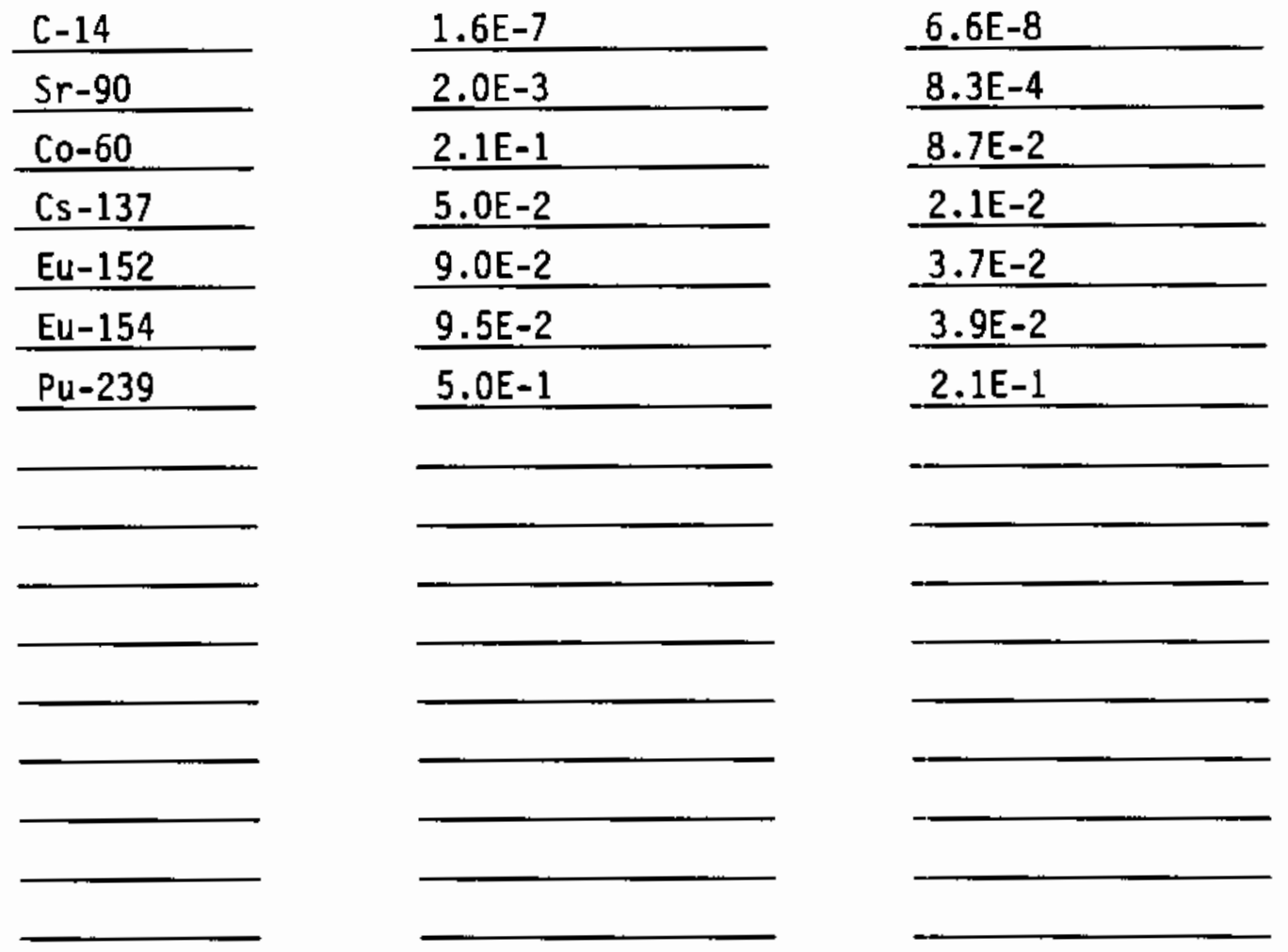

(a) From Table 2.2.

(b) Calculated as Item 5 times Column 7. 
Form E--Dose Variance [Var $\left.\left(D_{h}\right)\right]$ Calculation Worksheet for Stratum $h$

1. Facility and Stratum: 115-D/0R Paper - Recycle Scenario

2. Preparer's Hame: BA Napier 3. Date Prepared: $\underline{6 / 25 / 86}$ 4. Stratwn Mass $(m h): \underline{8.26 E+7 g}$ 5. Decay Iime $(t): \underline{100}$ yr

\begin{tabular}{|c|c|c|c|c|c|c|c|c|c|c|c|c|}
\hline & \multirow{3}{*}{\multicolumn{3}{|c|}{ Radionuclide $\mathrm{hk}$}} & \multicolumn{7}{|c|}{ Ahjk } & \multirow{4}{*}{ 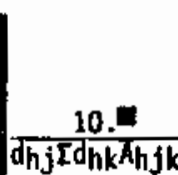 } \\
\hline & & & & & 2 & 3 & 4 & 5 & 6 & 7 & 8 & \\
\hline & & Radionuclide $\mathrm{hk}$ & & & $90 \mathrm{Sr}$ & $\frac{60 C_{0}}{25}$ & $137 \mathrm{Cs}$ & $252 \mathrm{Eu}$ & $154 \mathrm{EV}$ & $239 P_{4}$ & & \\
\hline & & $s \delta\left(d_{h j} y_{h, j}\right)$ & $-\frac{8}{x+3}$ & daj $\mathrm{d}_{\mathrm{h} k \mathrm{k}}$ & $\frac{2,4 E-2}{B, 3 E-16}$ & $\frac{1.3 E-1}{8.7 E-14}$ & $\frac{2,3 E-2}{2.1 E-14}$ & $\frac{5.2 E=-2}{3.7 E-14}$ & $\frac{\theta .5 E-2}{3.9 E-14}$ & $\frac{2.2 k-5}{2.1 E-13}$ & & \\
\hline \multicolumn{2}{|c|}{ 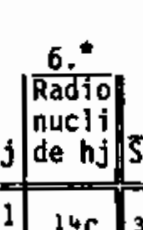 } & $3.8 E-12$ & $1,2 E-4$ & $6.6 E-20$ & $\frac{0.36}{1} e^{-2.4}$ & $\frac{40.94}{3} e^{-13} \cdot 1$. & $-\frac{212}{5} e^{\frac{l}{2}} 2 \cdot 31$ & $\frac{-0.3 \frac{4}{4}-5.21}{4}$ & $\frac{-1.6}{5} e^{-9.51}$ & $=\frac{0.97}{4}-0.015$ & $-\mathrm{e}^{-}$ & $-8.66 E-33$ \\
\hline 2 & \multirow[t]{2}{*}{${ }^{90} \mathrm{Sr}$} & $1.4 E-9$ & $2.4 \mathrm{E}-2$ & 8. $3 E-16 \mid$ & \multicolumn{2}{|r|}{$\frac{2}{2}-15.4$} & $\frac{16.7}{10}-4.70$ & $\frac{-0.45}{9} e^{-7} 7.60$ & $\frac{-0.599}{9} e^{2} 10.9$ & $=\frac{0.16-2.40}{1}$ & - & $-2.26 \mathrm{E}-30$ \\
\hline 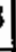 & & $9.6 E-11$ & 1. $3 \mathrm{E}-1$ & ด. $7 E-14$ & & & $\frac{-990}{11} e^{0} 15.3$ & $\frac{10.3}{10} \mathrm{e}-18.2$ & $\frac{\pi .3}{10} e-21.5$ & $\frac{36.0}{8} e^{-} 13.0$ & $-\mathrm{e}^{-}$ & $1,48-3$ \\
\hline \multirow[t]{2}{*}{4} & & $7.4 \mathrm{E}-6$ & $2,3 \mathrm{E}-2$ & $|2.1 E-14|$ & & & & $\frac{-62.2}{18}-7.50$ & $\frac{45.6}{10} e-10.8$ & $\frac{-79}{10} e^{\frac{1}{2}-2.30}$ & $-\mathrm{e}^{*}$ & $-3.49 \mathrm{E}-27$ \\
\hline & \multirow[b]{2}{*}{$152 \mathrm{Fu}$} & $=0$ & c. $0=0$ & $1,-5$ & & & & & $0.558-13.7$ & $0.003-5,20$ & - & \\
\hline & & 5. $9 E-9$ & $5.2 E-2$ & $3.75-14$ & & & & & & 96 & - & $2.86 \mathrm{E}-30$ \\
\hline \multirow[t]{2}{*}{ 6] } & \multirow{2}{*}{$\frac{154 \mathrm{EV}}{239}$} & 2. $8 \mathrm{E}-10$ & B. $5 \mathrm{E}-2$ & $3.9 \mathrm{E}-14$ & & & & & & $\frac{0.078}{9} \mathrm{e}^{-}-0.50$ & $\mathrm{e}^{-}$ & $1.25 \mathrm{E}-31$ \\
\hline & & 8. $2 \mathrm{E}-6$ & 2. $9 \mathrm{E}-5$ & $2.1 E-13 \mid$ & & & & & & & $\longrightarrow \mathrm{e}^{-}$ & \\
\hline & & & & 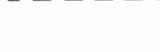 & & & \multicolumn{2}{|c|}{$2 m h^{2}-1,36 \mathrm{E}+16$} & \multicolumn{3}{|c|}{$I d_{h j} I_{d h k} A_{h j k}=-j .49 \mathrm{E}-27$} \\
\hline & & \multicolumn{3}{|c|}{$1.22 \mathrm{E}-10=\Sigma\left[S D\left(d_{h j} y_{h j}\right)\right]^{2}$} & . & 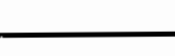 & ביביב & $2 \ln n^{2}$ & 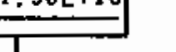 & & IdhjEdhkAhjk & \\
\hline \multicolumn{2}{|c|}{11.} & Oh) $=$ & & 2) & & & $1.22 \mathrm{E}-10$ & + & $6 E+16$ & $3.49 \mathrm{E}-27$ & $7.46 \mathrm{E}-11$ & $=\operatorname{Var}\left(\mathbf{O}_{h}\right)$ \\
\hline
\end{tabular}

- Column 6 [Radionuclide $j$ and $k$ ].-from Form $A$, Col. 4. Column 7 [SD(dhjyb)]--from Form 0, Col. $g$.

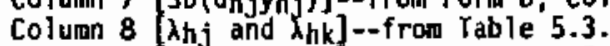

Column 9 [dhj and dhk $]$--from Form $D$, Col. 7.
1 Ahjk $=\frac{\hat{\sigma}_{h j k}}{n_{h j k}-\theta}$, where $\hat{o}_{h j k}$ is from form $\theta$, col. 10 , nhjk is from form B, Col. 11, and

- Column 10--calculated as $\mathrm{dhj}_{\mathrm{h}}\left[\mathrm{d}_{\mathrm{hk}} \mathrm{A}_{\mathrm{h} j \mathrm{k}}\right.$. 
Forn D - Stratue Dose Calculation Worksheot

1. Facility/Scenario and Stratun: $115 \mathrm{D} / \mathrm{DR}$ Building, Recycle Sconario, Pipes

2. Proparer's Hane: B. A. Napier

3. Date Prepared: $6 / 26 / 8 B$

5. Source 8. Source \begin{tabular}{ll} 
Considered & Toru \\
\hline
\end{tabular}

Factor (b)

(rea/yr per pCi)

Q. Estinated Dose(c)

(ren/yr)

9. S. D. of Dose (d)

(ren/yr)

Estianted

C-14

\begin{tabular}{ll}
$0.8 \mathrm{E}+7$ & $6 . \mathrm{BE}+7$ \\
\hline $0.0 E+6$ & $1.7+46$
\end{tabular}

Sr-90

$\frac{0.0 E+6}{1.7 E+6}$

Co-60

6. $6 \mathrm{E}-20$

6.6E-12 $3.0 \mathrm{E}-12$

$\frac{\mathrm{Cs}_{\mathrm{s}-137}}{\frac{2.6 \mathrm{E}+9}{1.6 \mathrm{E}+6}-\frac{1.5 \mathrm{E}+8}{1.6 \mathrm{E}+6}}$

in

$3.8 \mathrm{E}+4$

11. Variance of Estimated Dose $(\text { res/yr })^{2}{ }^{(f)}$ :
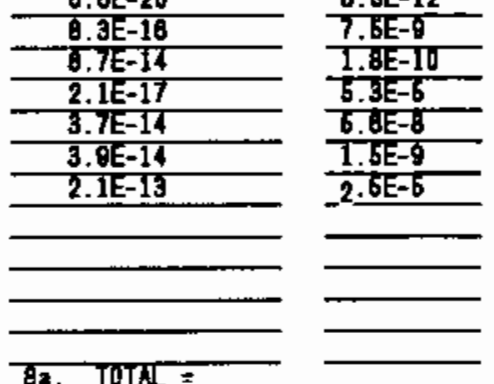

1.4E-9

$\frac{\text { 9.6E-11 }}{\text { T.4E-6 }}$

5.8E-8

$2.8 \mathrm{E}-10$

3.2E-6
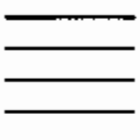

$00 \$$ UCL Dose(0)

(rae/yr)

7.42E-11

(a) Fros Forn 8 - Source Tern Torksheot (colunn 10 or 12), for $T=100$ years.

(b) Frow Forn C - Availability, Forn F - Area, Forn O - Depth, or Forn H - bass Correction Torkaheets, as appropriate.

(c) Calculate as the product of Coluans 5 and 7

(d) Calculate as the product of Coluans 6 and 7 .

(o) Calculate as (Colum 8) $+\mathrm{z}_{1-\alpha}$ (Coluan 8), where $\mathrm{z}_{1-a}$ is chosen to correspond with the desirod conf idence level fron Tablo 5.5 .

(f) Calculate using Procedure 3.2.2, Colunns 7, 9, and Coluans 8, 9, 10, and 11 froe Forn A - Sumatry Statistica Torksheet on Forn $E$ (Dose Variance Calculation Dorkeheet)

(g) $9.8 \mathrm{E}+7=9.8 \mathrm{E}+10^{7}$ 


\section{Form I - Final ARCL Worksheet - Summed Over A1l Strata}

1. Facility/Scenario: 115 D/DR Building, Recycle Scenario, Pipes

2. Preparer's Name: B. A. Napier

3. Date Prepared: $6 / 26 / 86$

4. Stratum or Scenario Considered (a)

Pipes

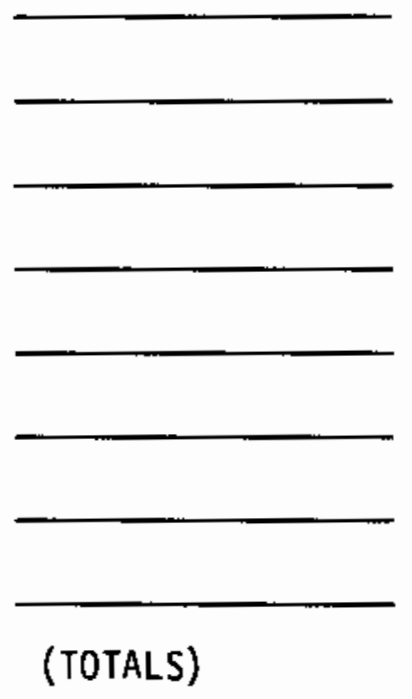

5. Total Dose per Stratum or Scenario (rem/yr) (b)

\section{$7.8 \mathrm{E}-5$}

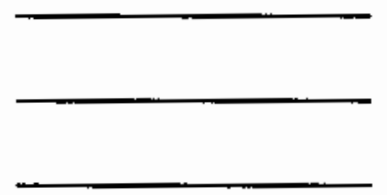

$$
5 a=7.8 E-5
$$

7. $(6 a) 1 / 2=S D\left[\hat{U}_{S}(t)\right]=8.6 E-6$

8. $5 a+z_{1-\alpha}^{(d)} * 7=8.9 \mathrm{E}-5$
6. Variance of the Dose $(c)$ $(\mathrm{rem} / \mathrm{yr})^{2}$

\subsection{E-11}

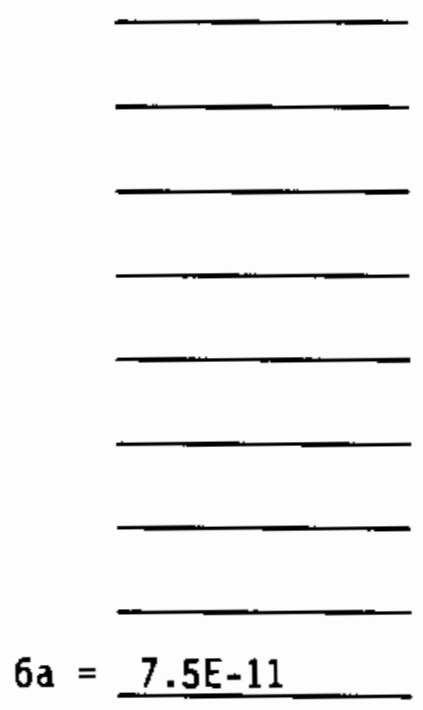

\footnotetext{
(a) Note: Forms $A, B, C$, and D are completed for each Stratum considered.

(b) From Item $8 \mathrm{~b}$ in Form $D$, for each Stratum considered.

(c) From Item 11 in Form $D$, for each Stratum considered.

(d) Obtained from Table 5.5.
} 


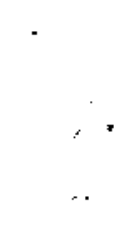




\section{APPENDIX B}

COPIES OF THE WORKSHEETS AND TABLES USED

FOR PERFORMING ARCL CALCULATIONS 
TABLE B.1. Worksheets Used for ARCL Analysis of Contaminated Facilities

\begin{tabular}{|c|c|}
\hline Form & Title \\
\hline A & $\begin{array}{l}\text { Summary Statistics Table--Estimated Means } \\
\text { Standard Deviations, and Covariances per Stratum }\end{array}$ \\
\hline B & Source-Term Worksheet \\
\hline C & Availability Correction Worksheet \\
\hline D & Stratum Dose Calculation Worksheet \\
\hline$E$ & Dose Variance Calculation Worksheet \\
\hline $\mathrm{F}$ & Area Correction Worksheet \\
\hline G & Depth Correction Worksheet \\
\hline$H$ & Mass Correction Worksheet \\
\hline I & Final ARCL Worksheet \\
\hline
\end{tabular}

Figure Number in Text

Figure 5.3

Figure 5.5

Figure 5.7

Figure 5.8

Figure 5.9

Figure 5.11

Figure 5.12

Figure 5.14

Figure 5.16 
IABLE B.2. Decay Constants for Selected Radionuclides $\left(\mathrm{yr}^{-1}\right)$

\begin{tabular}{|c|c|c|c|}
\hline Nuclide & Constant & Nuclide & Constant \\
\hline $3 H$ & $5.6 \mathrm{E}-2$ & $134 \mathrm{Cs}$ & $3.4 \mathrm{E}-1$ \\
\hline $14 \mathrm{C}$ & $1.2 \mathrm{E}-4$ & $135 \mathrm{Cs}$ & $3.4 \mathrm{E}-7$ \\
\hline $36 \mathrm{Cl}$ & $2.2 E-6$ & $137 C_{s}+D$ & $2.3 \mathrm{E}-2$ \\
\hline $57 \mathrm{CO}$ & $9.3 \mathrm{E}-1$ & ${ }^{144} \mathrm{Ce}$ & $8.9 E-1$ \\
\hline $60 \mathrm{Co}$ & 1. $3 \mathrm{E}-1$ & $152 \mathrm{Eu}$ & $5.2 \mathrm{E}-2$ \\
\hline $55 \mathrm{Fe}$ & $2.6 \mathrm{E}-1$ & ${ }^{154} \mathrm{Eu}$ & $8.5 E-2$ \\
\hline $59 \mathrm{Fe}$ & $5.6 \mathrm{E}+0$ & $226 \mathrm{Ra}$ & $4.3 E-4$ \\
\hline $59 \mathrm{Ni}$ & $8.7 E-6$ & 232Th & $5.0 \mathrm{E}-4$ \\
\hline $63 \mathrm{Ni}$ & $6.9 \mathrm{E}-3$ & $235 u+0$ & $9.8 \mathrm{E}-10$ \\
\hline $90 \mathrm{~s} r+0$ & $2.4 \mathrm{E}-2$ & $238 u+0$ & $1.6 \mathrm{E}-10$ \\
\hline $93 \mathrm{Mo}$ & $2.0 \mathrm{E}-4$ & $237_{N p+D}$ & $3.2 \mathrm{E}-7$ \\
\hline $94 \mathrm{Nb}$ & $3.5 \mathrm{E}-5$ & $238 p_{u}$ & $7.9 \mathrm{E}-3$ \\
\hline${ }^{99} \mathrm{TC}$ & $3.2 \mathrm{E}-6$ & $239 \mathrm{pu}$ & $2.9 \mathrm{E}-5$ \\
\hline $124 \mathrm{Sb}$ & $4.2 \mathrm{E}+0$ & $241_{\text {Am }}$ & $1.6 \mathrm{E}-3$ \\
\hline $125 S b+D$ & $2.5 \mathrm{E}-1$ & & \\
\hline
\end{tabular}


IABLE B.3. ARCL Scenario-Specific Dose Conversion Factors in Effective Dose Equivalent rem/yr per pCi

Scenario (rem/yr per oCi/Stratum)

\begin{tabular}{|c|c|c|c|c|}
\hline $\begin{array}{l}3 \mathrm{H} \\
14 \mathrm{C} \\
36 \mathrm{Cl} \\
57 \mathrm{Co}\end{array}$ & $\begin{array}{l}1 . \overline{\mathrm{E}}-19 \\
1.4 \mathrm{E}-17 \\
1.4 \mathrm{E}-14\end{array}$ & $\begin{array}{l}2.4 \mathrm{E}-20 \\
4.1 \mathrm{E}-18 \\
4.7 \mathrm{E}-16 \\
1.3 \mathrm{E}-13\end{array}$ & $\begin{array}{l}3.1 E-14 \\
3.1 E-14 \\
1.5 E-12 \\
7.3 E-16\end{array}$ & $\begin{array}{l}2.1 \mathrm{E}-14 \\
2.1 \mathrm{E}-14 \\
1.0 \mathrm{E}-12 \\
4.9 \mathrm{E}-16\end{array}$ \\
\hline $\begin{array}{l}60 \mathrm{Co} \\
55 \mathrm{Fe} \\
59 \mathrm{Fe}\end{array}$ & $\begin{array}{l}2.1 \mathrm{E}-13 \\
3.6 \mathrm{E}-18 \\
7.5 \mathrm{E}-14\end{array}$ & $\begin{array}{l}4.3 \mathrm{E}-12 \\
5.9 \mathrm{E}-17 \\
1.9 \mathrm{E}-12\end{array}$ & $\begin{array}{l}1.0 \mathrm{E}-14 \\
2.5 \mathrm{E}-17 \\
2.3 \mathrm{E}-16\end{array}$ & $\begin{array}{l}6.7 \mathrm{E}-15 \\
1.7 \mathrm{E}-17 \\
1.5 \mathrm{E}-16\end{array}$ \\
\hline $\begin{array}{l}59 \mathrm{Ni} \\
63 \mathrm{Ni} \\
90 \mathrm{Sr}+\mathrm{D}\end{array}$ & $\begin{array}{l}1.9 \mathrm{E}-17 \\
1.9 \mathrm{E}-17 \\
2.0 \mathrm{E}-15\end{array}$ & $\begin{array}{l}7.3 \mathrm{E}-17 \\
6.7 \mathrm{E}-19 \\
1.1 \mathrm{E}-14\end{array}$ & $\begin{array}{l}3.8 \mathrm{E}-16 \\
1.0 \mathrm{E}-15 \\
2.7 \mathrm{E}-12\end{array}$ & $\begin{array}{l}2.5 \mathrm{E}-16 \\
6.7 \mathrm{E}-16 \\
1.8 \mathrm{E}-12\end{array}$ \\
\hline $\begin{array}{l}93 \mathrm{Mo} \\
94 \mathrm{Nb} \\
99 \mathrm{Tc}\end{array}$ & $\begin{array}{l}1.4 \mathrm{E}-14 \\
1.2 \mathrm{E}-13 \\
1.7 \mathrm{E}-18\end{array}$ & $\begin{array}{l}2.0 \mathrm{E}-16 \\
2.6 \mathrm{E}-12 \\
3.0 \mathrm{E}-17\end{array}$ & $\begin{array}{l}1.9 \mathrm{E}-14 \\
7.3 \mathrm{E}-15 \\
3.4 \mathrm{E}-13\end{array}$ & $\begin{array}{l}1.3 E-14 \\
4.9 E-15 \\
2.3 E-13\end{array}$ \\
\hline $\begin{array}{l}124 \mathrm{Sb} \\
125 \mathrm{Sb}+\mathrm{D} \\
134 \mathrm{Cs}\end{array}$ & $\begin{array}{l}1.4 \mathrm{E}-13 \\
3.4 \mathrm{E}-14 \\
1.2 \mathrm{E}-13\end{array}$ & $\begin{array}{l}3.5 \mathrm{E}-12 \\
8.0 \mathrm{E}-13 \\
2.9 \mathrm{E}-12\end{array}$ & $\begin{array}{l}\text { 1. } 0 \mathrm{E}-14 \\
\text { 3. } 4 \mathrm{E}-15 \\
1.4 \mathrm{E}-14\end{array}$ & $\begin{array}{l}6.7 \mathrm{E}-15 \\
2.3 \mathrm{E}-15 \\
9.3 \mathrm{E}-15\end{array}$ \\
\hline $\begin{array}{l}135 \mathrm{Cs} \\
137 \mathrm{Cs}+\mathrm{D} \\
144 \mathrm{Ce}+\mathrm{D}\end{array}$ & $\begin{array}{l}6.5 \mathrm{E}-17 \\
5.0 \mathrm{E}-14 \\
4.4 \mathrm{E}-15\end{array}$ & $\begin{array}{l}8.7 \mathrm{E}-18 \\
1.0 \mathrm{E}-12 \\
9.3 \mathrm{E}-14\end{array}$ & $\begin{array}{l}1.4 \mathrm{E}-15 \\
1.0 \mathrm{E}-14 \\
1.1 \mathrm{E}-15\end{array}$ & $\begin{array}{l}9.3 \mathrm{E}-16 \\
6.7 \mathrm{E}-15 \\
7.1 \mathrm{E}-16\end{array}$ \\
\hline $\begin{array}{l}152 \mathrm{Eu} \\
154 \mathrm{Eu} \\
226 \mathrm{Ra}\end{array}$ & $\begin{array}{l}9.0 \mathrm{E}-14 \\
9.5 \mathrm{E}-14 \\
3.4 \mathrm{E}-14\end{array}$ & $\begin{array}{l}2.0 \mathrm{E}-12 \\
2.1 \mathrm{E}-12 \\
3.5 \mathrm{E}-12\end{array}$ & $\begin{array}{l}1.7 \mathrm{E}-15 \\
2.5 \mathrm{E}-15 \\
4.3 \mathrm{E}-11\end{array}$ & $\begin{array}{l}1.2 \mathrm{E}-15 \\
1.6 \mathrm{E}-15 \\
2.8 \mathrm{E}-11\end{array}$ \\
\hline $\begin{array}{l}232 \mathrm{Th} \\
235 \mathrm{U}+\mathrm{D} \\
238 \mathrm{U}+\mathrm{D}\end{array}$ & $\begin{array}{l}2.0 \mathrm{E}-14 \\
1.0 \mathrm{E}-14 \\
6.0 \mathrm{E}-15\end{array}$ & $\begin{array}{l}4.9 \mathrm{E}-12 \\
1.7 \mathrm{E}-13 \\
6.7 \mathrm{E}-14\end{array}$ & $\begin{array}{l}1.6 \mathrm{E}-12 \\
7.3 \mathrm{E}-15 \\
1.2 \mathrm{E}-16\end{array}$ & $\begin{array}{l}1.1 \mathrm{E}-12 \\
4.9 \mathrm{E}-15 \\
8.0 \mathrm{E}-17\end{array}$ \\
\hline $\begin{array}{l}237 \mathrm{~Np}+\mathrm{D} \\
238 \mathrm{Pu} \\
239 \mathrm{Pu}\end{array}$ & $\begin{array}{l}7.5 \mathrm{E}-13 \\
4.7 \mathrm{E}-13 \\
5.0 \mathrm{E}-13\end{array}$ & $\begin{array}{l}5.7 \mathrm{E}-13 \\
8.0 \mathrm{E}-14 \\
8.7 \mathrm{E}-14\end{array}$ & $\begin{array}{l}1.4 \mathrm{E}-12 \\
9.3 \mathrm{E}-15 \\
1.1 \mathrm{E}-14\end{array}$ & $\begin{array}{l}9.3 \mathrm{E}-13 \\
6.2 \mathrm{E}-15 \\
7.1 \mathrm{E}-15\end{array}$ \\
\hline $241_{\mathrm{Am}}$ & $4.5 \mathrm{E}-13$ & $1.3 \mathrm{E}-13$ & $1.0 \mathrm{E}-13$ & $6.7 \mathrm{E}-14$ \\
\hline
\end{tabular}


TABLE B.4. Standard Normal Distribution Values $z 1-\alpha$ Such that $(1-\alpha) 100 \%$ of the Distribution Lies to the Left of $Z_{1-a}$

$\begin{array}{cl}\frac{(1-a) 100 \%}{2} & \frac{z_{1-\alpha}}{2.33} \\ 99 & 1.96 \\ 97.5 & 1.645 \\ 95 & 1.282 \\ 90 & \end{array}$


Form A - Sumary Statistics Table

1. Facility and Stratun:

2. Preparer's Nano:

\section{Preparor's Nano:}

4. Radionuclide 5. Uoan $\bar{x}_{h i}$ 6. 5. D.

\begin{tabular}{l} 
4. Radionuclide \\
Considered \\
\hline
\end{tabular}

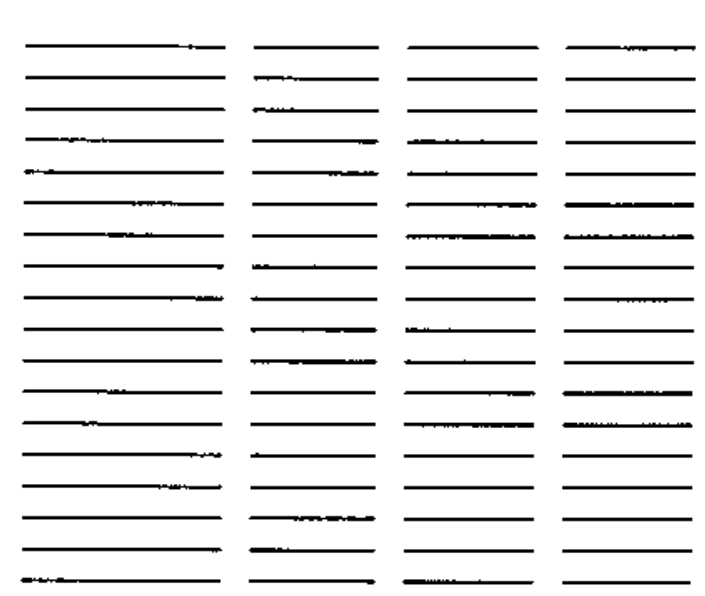

(a) Note: Coluans 8-11 vill be auch

Comments
3. Date Propared:

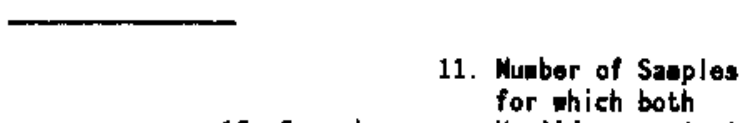

for which both

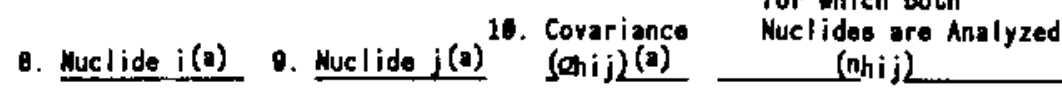

(nhij)

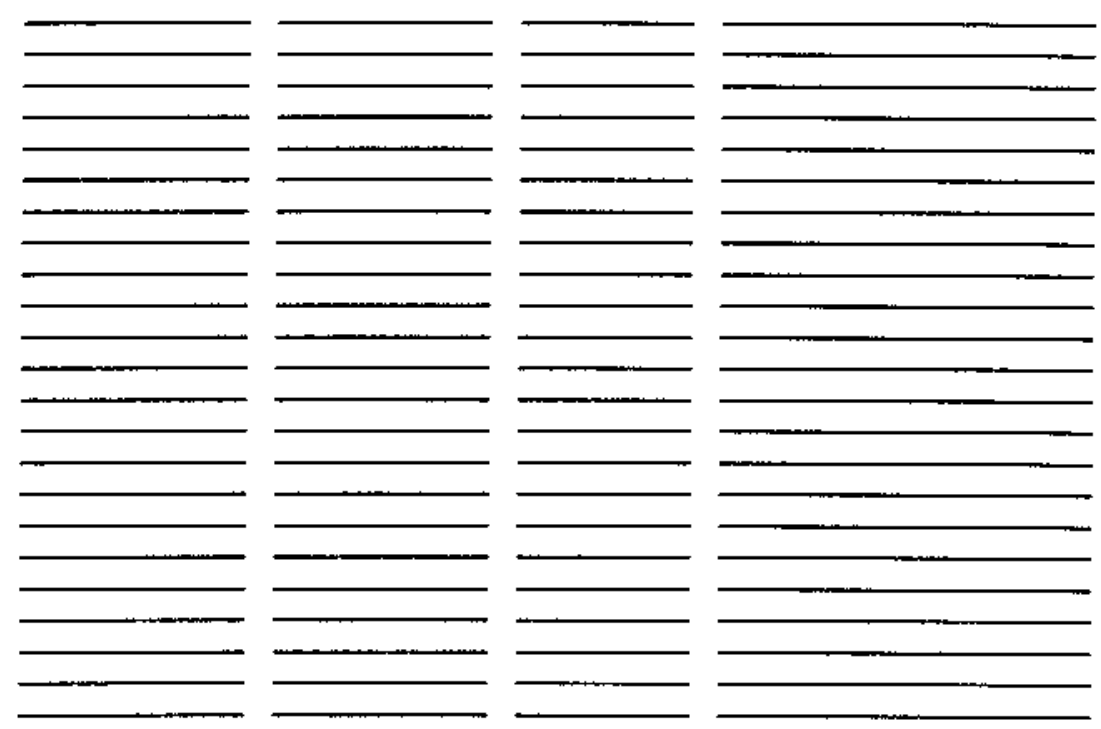


1. Facility/Scenario and Stratua:

2. Preparer's Nano:

3. Date Preparod:

4. Stratun Mass (a) (grans):

5. Nuaber of Years of Decay:

7. Lean Con- B. Stratum Concontration centration 0 . Nuaber of in Stratun, S. D.,(b) Sanples

8. Radionuctide xhi oni Considered

$$
(\mathrm{pCi} / \mathrm{ghi})^{(b)}
$$

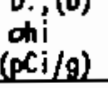
in Stratur
in Sitb)

10. Source

Source 11.5

$$
\text { this (d) }
$$

11. S. D.

12. Docayed

$\begin{array}{lll}\text { Source } & \text { 13. Decayed } \\ \text { Tore } & \text { S. D } \\ \text { (pCi) (o) } & \text { thi(f) }\end{array}$
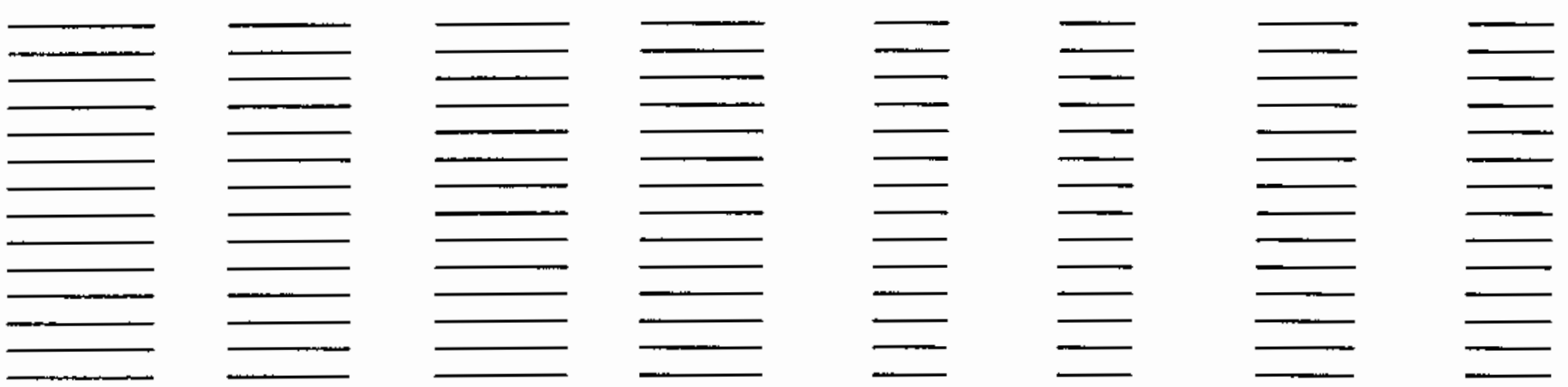

(a) Strata are defined to consist only of contan inated naterial

(b) Copy from Forn $A$ - Suncary Statistics Table (Table 5.2.1).

(c) Calculate as Iten 4 tines Iten 7 .

(d) S. D. $\left(g_{h i}\right)=\left(\frac{m^{2} h_{i}}{n h i}\right)^{1 / 2}$

(e) Calculate as Itom 10 tines o- $\lambda_{i} t$ there $\lambda_{i}=$ docay constant for radionuclide $i$ (fron Table 6.2 .3 ) and $t=$ nuaber of years of

(f) Calculate as Itea 11 tiese o- $\lambda_{i t}$ whero $\lambda_{i}=$ docay constant for radionuclido $i$ (fros Table 5.2 .3 ) and $t=$ nuaber of years of decay (Ites 5). 
Forn C - Availability Correction Torkshoet

1. Facility/Scosario and Stratun:

2. Proparor's Mamo:

3. Dale Propared:

4. Radionuclide Considered

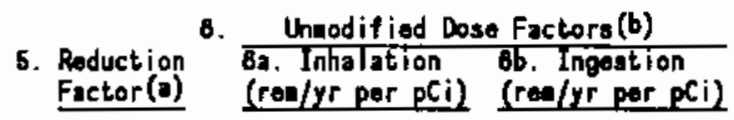

7. Corrected Dose Factors (c) 7.. Inholation 76. Ingestion

B. Rosidential/Howe Garden(a) (reulyr per $p C i)$ (reo/yr por pCi)

Scenario Dose Factors

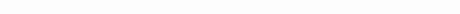

(ree/yr par pCi)
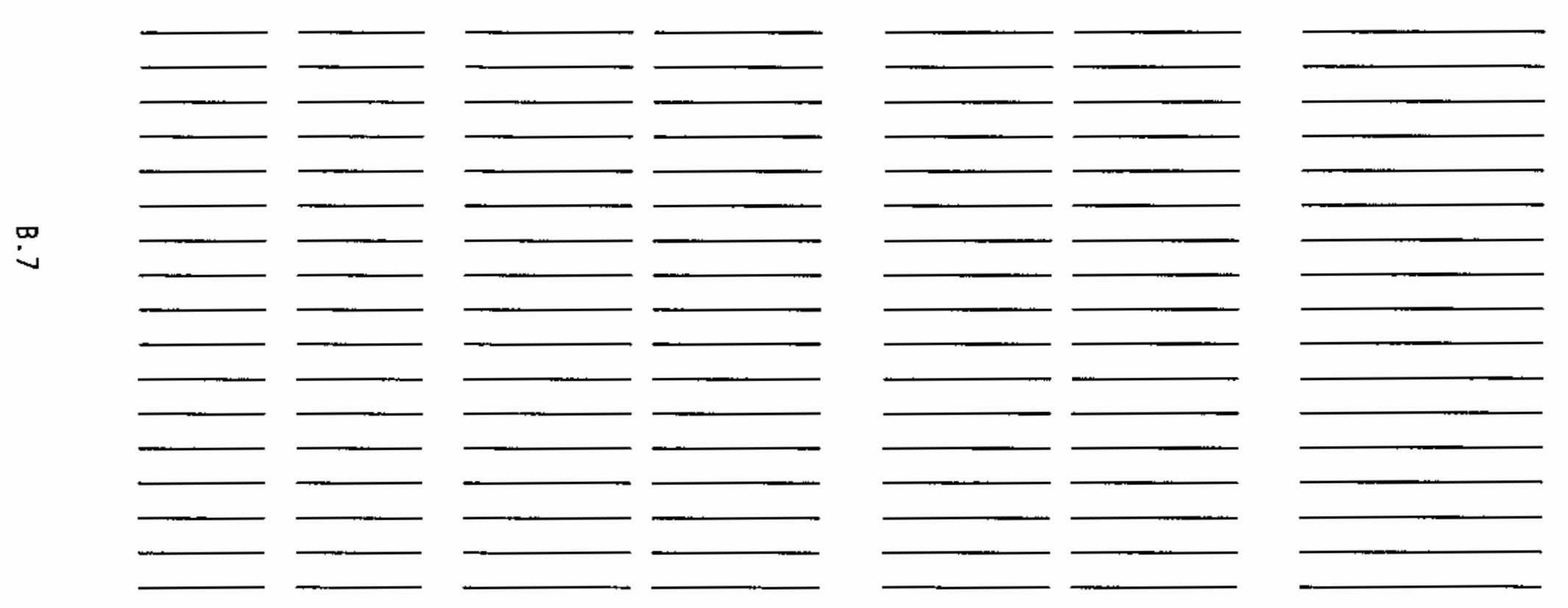

(a) 1.0 for radionuclides not containod in activalod notals. $\mathrm{RF}=2 \mathrm{t}$ (corrosion rate $\mathrm{cn} / \mathrm{yr}$ )/(thickness in $\mathrm{ca}$ ).

(b) Fros Table 2.2 .

(c) Calculated as the product of coluans 5 and 6 , by radionuclide.

(d) Conplete this coluen only for the Residential/Hone Gorden scenario. The sconario dose factors are calculated as Colunn 7a plus Coluan $7 b$. 
Fore D - Stratye Dose Calculation Dorksheet

1. Facility/Scenario and Stratua:

2. Preparer's Nase:

3. Date Propared:

7. Sconario Doso Factor (b)

4. Radionuclide Torm Torn S, D Considered

$(p \mathrm{Ci})(\mathrm{a})$

(pCi) (a)

8. Eatieated Dose (c)

(ren/yr)

D. S. D.

(rodyr per pCi)

$(r \in u / y r)$

10. Eatinated

i Ul. Dose(e)

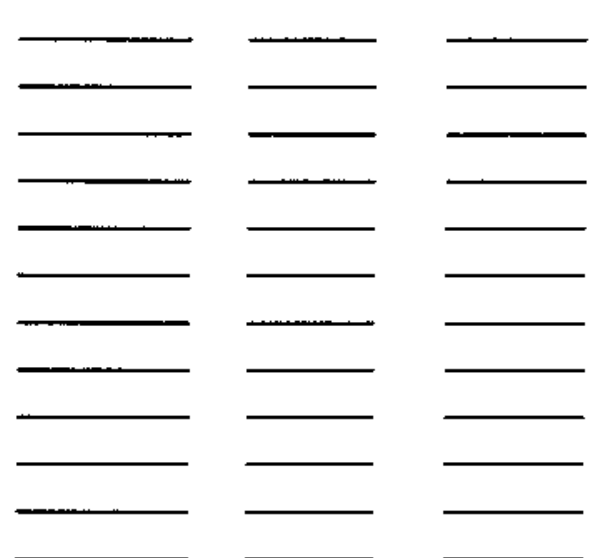

11. Variance of Estinated Dose $(\mathrm{ren} / \mathrm{yr})^{2}{ }^{(f)}$ :

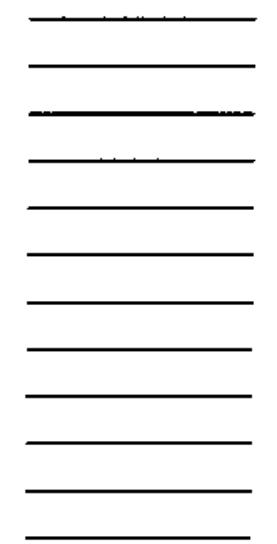

8a. TOTN $=$

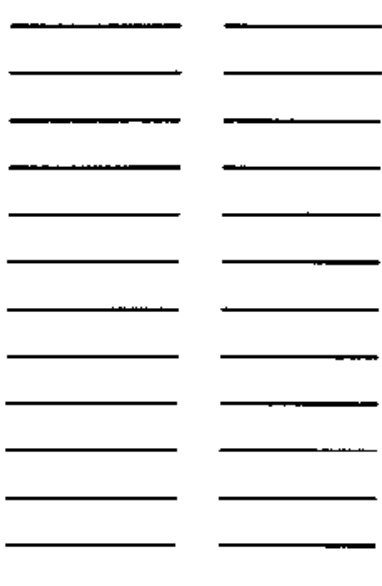

(a) Fros Fore 9 - Source Tern torkeheot (coluen 10 or 12), for $T=$ years.

(b) Fron Fore C - Availability, Forn F - Area, form O - Depth, or Forn H - lass Correction Iorksheets, as appropriate.

(c) Calculate as the product of Coluns 5 and 7 .

(d) Calculate as the product of Columns 8 and 7 .

(0) Calculate as (Colunn $\theta)+z_{1-\alpha}$ (Coluan 8 ), there $z_{1-\alpha}$ is chosen to correspond with the desired conf idence

level fron Table 5.5.

(f) Calculate using Procedura 3.2.2, Coluans 7, 9, and Coluans 8, 9, 10, and 11 from Forn A - Sunmery Statistics Vorksheet on Fora E (Dose Yariance Calculation Torksheot. 


\section{Forn E--Dose Yariance [Var( $\left.0_{h}\right)$ ]_calculation Morksheet for Stratum h}

1. Facility and Stratum:

2. Preparer's Name:

3. Date Prepared:

4. Stratum Mass (畉)

g 5. Deces: Tine (t):

yr

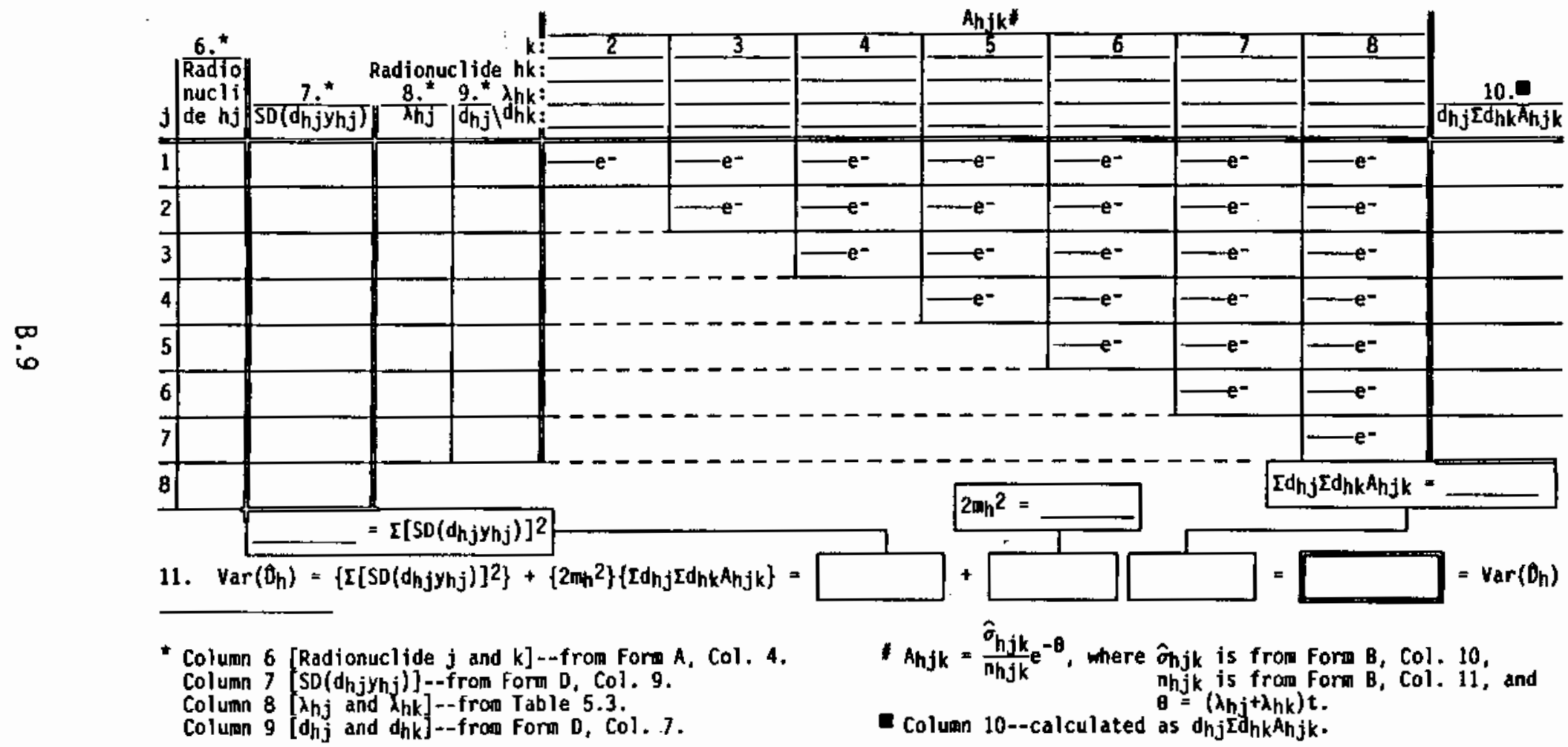




\section{Formh F - Area Correction Worksheet}

1. Facility:

2. Preparer's Name:

3. Date Prepared:

4. Area of Contamination Within 1-ha Site $m^{2}=$ ha

5. Correction Factor $=0.1+9($ Item 4$)=$

6. Radionuclide 7. Ingestion $\mathrm{DF}(\mathrm{rem} / \mathrm{yr} / \mathrm{pCi})(\mathrm{a})$

8. Corrected Ingestion DF(rem/yr/DCi) (b)
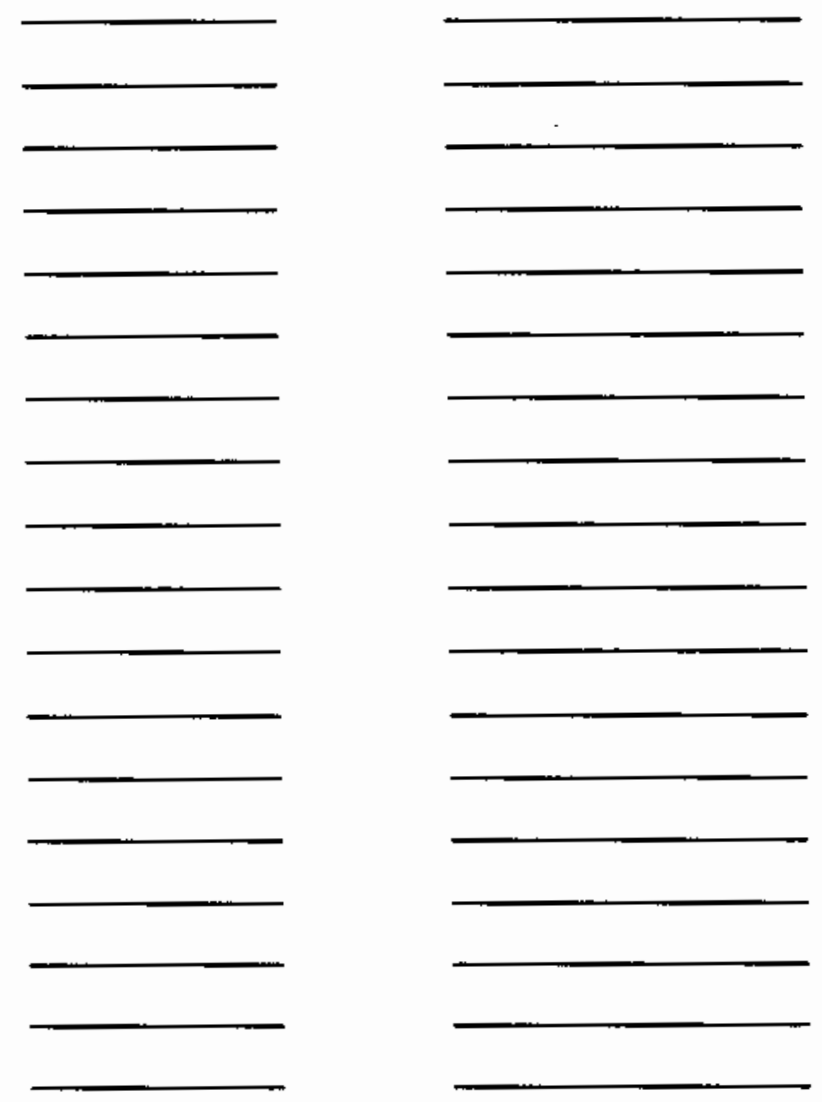

(a) From Availability Correction Worksheet.

(b) Calculated as Item 5 times Column 7. 


\section{Form G. Depth Correction Worksheet}

1. Facility:

2. Preparer's Name:

3. Date Prepared:

4. Depth of Clean overburden $\boldsymbol{m}$.

5. Calculate depth correction factor (DCF) as $D C F=e^{-0.92(\text { Depth })}=$

If Depth $>10$ meters DCF $=0.0$.

6. Radionuclide
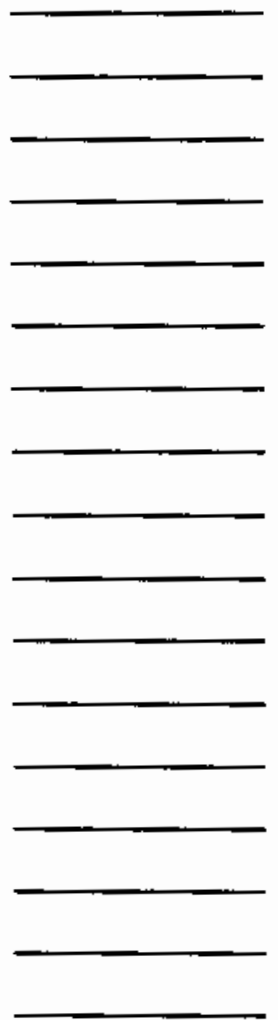

7. Ingestion $\underline{0 F}(\mathrm{rem} / \mathrm{yr} / \mathrm{pCi})(\mathrm{a})$

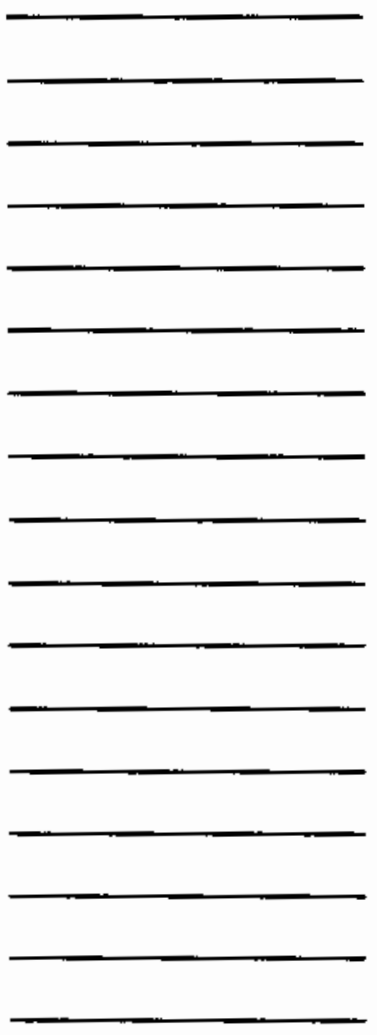

8. Corrected Ingestion $\mathrm{DF}(\mathrm{rem} / \mathrm{yr} / \mathrm{pCi})(\mathrm{b})$

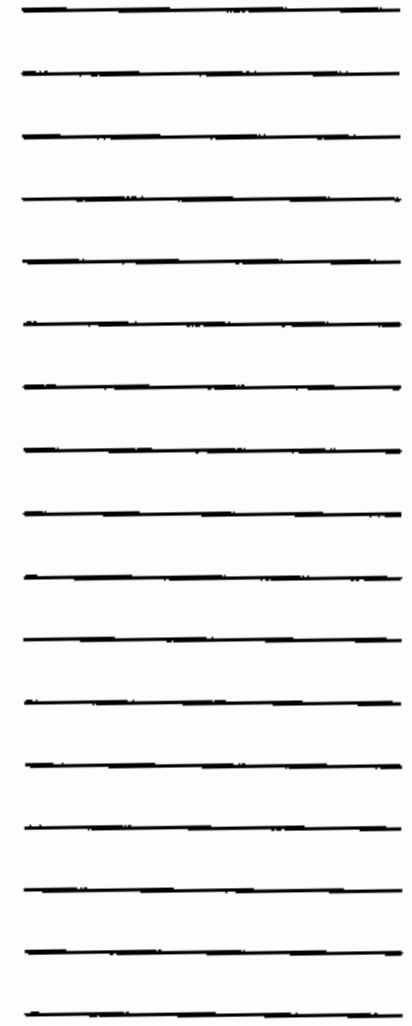

(a) From Form F - Area Correction or Form C - Availability Worksheet. (b) Calculated as Item 5 times Column 7. 


\section{Form H - Mass Correction Worksheet}

1. Facility:

2. Preparer's Name:

3. Date Prepared:

4. Mass of contaminated metal, $\mathrm{Mg}$.

5. Calculate mass correction factor (MCF) as MCF $=$ Item $4 / 200=$

6. Radionuclide
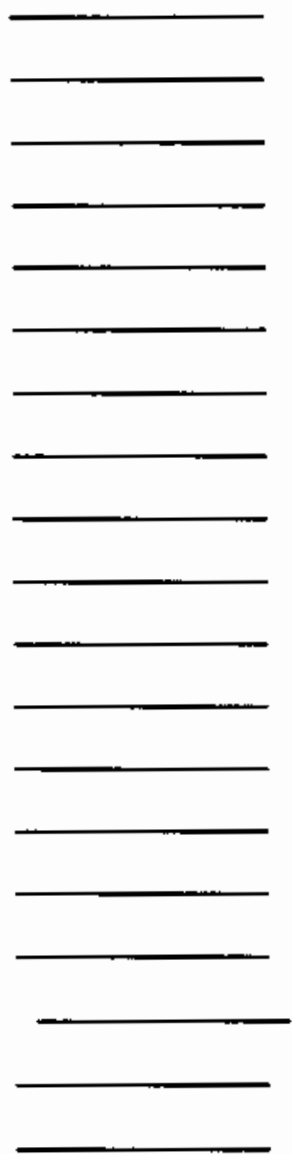

7. Recycle DF $(r e m / v r / p C i)(a)$

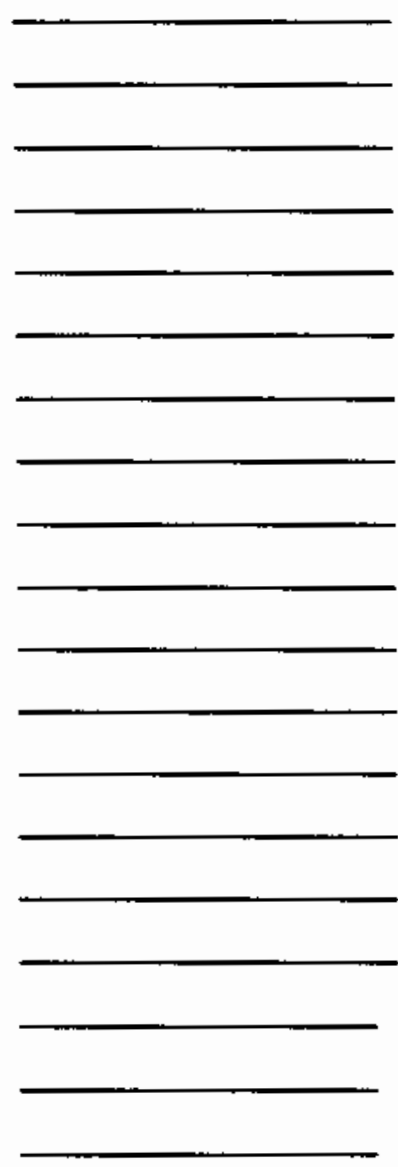

(a) From Table 2.2.

(b) Calculated as Item 5 times Column 7.
Adjusted

DF $(r e m / y r / c i)(b)$

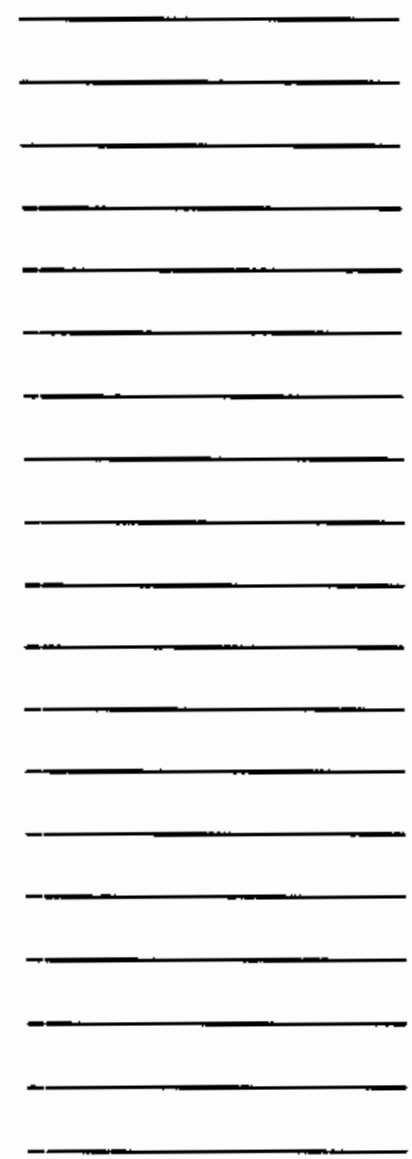




\section{Form I - Final ARCL Worksheet - Sunmed Over All Strata}

1. Facility/Scenario:

2. Preparer's Name:

3. Date Prepared:

\section{Stratum or Scenario Considered (a)}

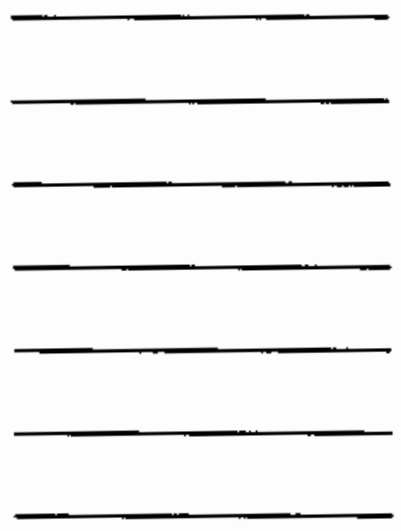

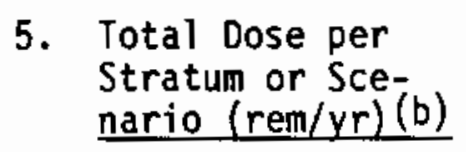
6. Variance of the Dose (c) $(\mathrm{rem} / \mathrm{yr})^{2}$
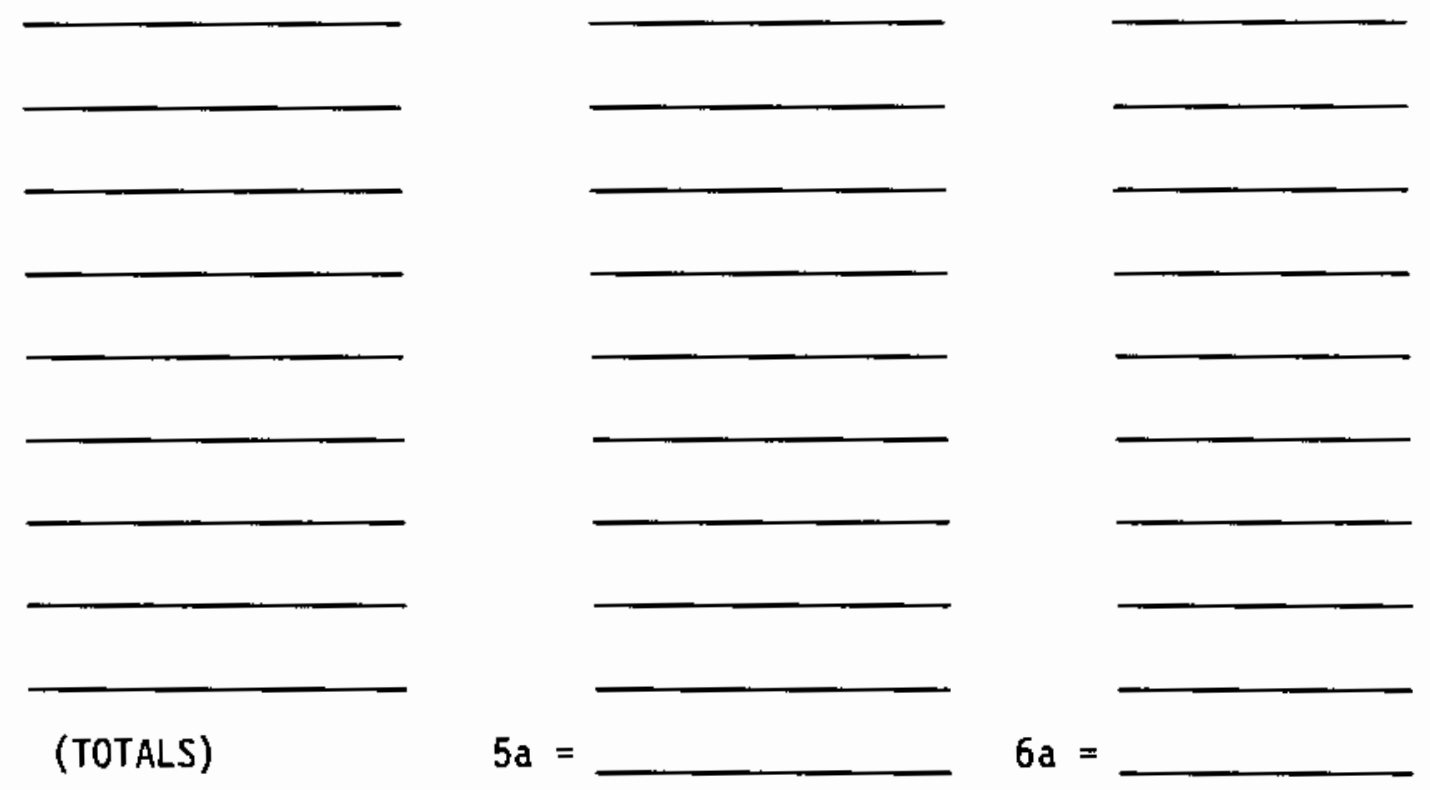

7. (6a) $1 / 2=S D\left[O_{S}(t)\right]=$

8. $5 a+z^{(d)} * 7=$ $\%$ UCL)
(a) Note: Forms $A, B, C$, and D are completed for each Stratum considered.
(b) From Item $8 b$ in Form 0 for each Stratum considered.
(c) Form $D$ for each Stratum considered.
(d) Obtained from Table 5.5. 
'

1

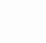

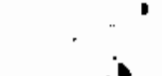


PNL -6348

UC -602

\section{DISTRIBUTION}

No. of

Copies

OFFSITE

2 DOE Technical Information Center

\section{ONSITE}

3 DOE Richland Operations Office

E. A. Erichsen

J. D. Goodenough

M. W. Tiernan

20 Westinghouse Hanford Company

J. F. Beckstrom (5)

J. F. Bertsch

G. F. Boothe

H. F. Daugherty

F. G. Demert

L. P. Diediker

J. S. Davis

K. A. Gano

W. F. Hiene

M. G. Hughes

P. D. Rittman

D. R. Speer (5)
No, of

Copies

65 Pacific Northwest Laboratory

W. J. Bajr

D. H. Denham

L. G. Faust

R. H. Gray

M. S. Hanson

G. R. Hoenes

J. R. Houston

J. R. Johnson

W. E. Kennedy, Jr. (10)

D. E. Lucas

E. B. Moore, Jr.

B. A. Napier (20)

I. C. Nelson

G. F. Peipel (5)

J. V. Robinson

R. G. Schreckh ise (5)

J. M. Selby

R. I. Smith

J. K. Soldat

S. L. Stein

W. L. Templeton

J. R. Weber

Publishing Coordination (2)

Technical Information (5) 


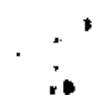

$\therefore$

,'

.

. 